\title{
The Modernist Bestiary
}

Translating Animals and the Arts through Guillaume Apollinaire, Raoul Dufy and Graham Sutherland

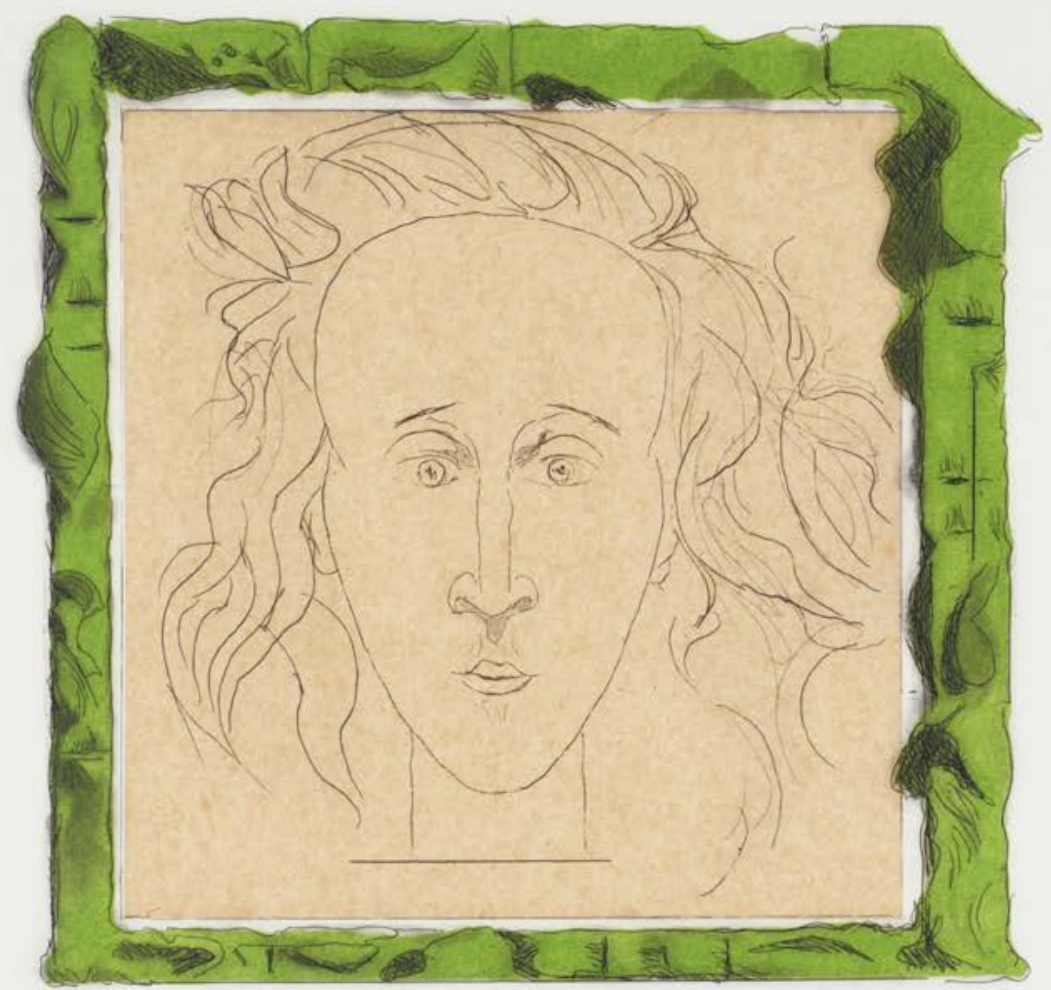

Edited by

Sarah Kay and Timothy Mathews 
The Modernist Bestiary 
COMPARATIVE LITERATURE AND CULTURE

\author{
Series Editors \\ TIMOTHY MATHEWS AND FLORIAN MUSSGNUG
}

\begin{abstract}
Comparative Literature and Culture explores new creative and critical perspectives on literature, art and culture. Contributions offer a comparative, cross-cultural and interdisciplinary focus, showcasing exploratory research in literary and cultural theory and history, material and visual cultures, and reception studies. The series is also interested in language-based research, particularly the changing role of national and minority languages and cultures, and includes within its publications the annual proceedings of the 'Hermes Consortium for Literary and Cultural Studies'.
\end{abstract}

Timothy Mathews is Emeritus Professor of French and Comparative Criticism, UCL.

Florian Mussgnug is Reader in Italian and Comparative Literature, UCL. 


\section{The Modernist Bestiary}

Translating Animals and the Arts through Guillaume Apollinaire, Raoul Dufy and Graham Sutherland

Edited by

Sarah Kay and Timothy Mathews 
First published in 2020 by

UCL Press

University College London

Gower Street

London WC1E 6BT

Available to download free: www.uclpress.co.uk

Collection (C) Editors, 2020

Text (C) Contributors, 2020

Images (C) Copyright holders named in captions, 2020

The authors have asserted their rights under the Copyright, Designs and Patents Act 1988 to be identified as the authors of this work.

A CIP catalogue record for this book is available from The British Library.

This book is published under a Creative Commons 4.0 International licence (CC BY 4.0). This licence allows you to share, copy, distribute and transmit the work; to adapt the work and to make commercial use of the work, providing attribution is made to the authors (but not in any way that suggests that they endorse you or your use of the work). Attribution should include the following information:

Kay, S. and Mathews, T. (eds.). 2020. The Modernist Bestiary: Translating Animals and the Arts through Guillaume Apollinaire, Raoul Dufy and Graham Sutherland. London: UCL Press. DOI: https://doi.org/10.14324/111.9781787351516

Further details about Creative Commons licences are available at http://creative commons.org/licenses/

Any third-party material in this book is published under the book's Creative Commons licence unless indicated otherwise in the credit line to the material. If you would like to reuse any third-party material not covered by the book's Creative Commons licence, you will need to obtain permission directly from the copyright holder.

ISBN: 978-1-78735-182-0 (Hbk.)

ISBN: 978-1-78735-157-8 (Pbk.)

ISBN: 978-1-78735-151-6 (PDF)

ISBN: 978-1-78735-188-2 (epub)

ISBN: 978-1-78735-206-3 (mobi)

DOI: https://doi.org/10.14324/111.9781787351516 


\section{Contents}

List of illustrations vii

Notes on contributors ix

Acknowledgements xiii

Headpiece: Oblique and prolonged $\quad 1$

Timothy Mathews

1 Graham Sutherland - The Bestiary or the Procession of Orpheus: An introduction

Dawn Ades

2 The Voice of Light: Nature and revelation in The Bestiary or the Procession of Orpheus

Sarah Kay

3 Ombre terreuse: Shades of meaning in Vergil, Ovid and Apollinaire

Sarah Spence

4 Apollinaire's Octosyllabic Quatrain, Translation and Zoopoetics Clive Scott

5 Animals on Parade: Collecting sounds for l'histoire naturelle of modern music

Rachel Mundy

6 Beasts of Flesh and Steel: The post-industrial bestiaries of Apollinaire, Dufy and Sutherland

Matthew Senior

7 How is Orpheus honoured? Procession, association and loss Timothy Mathews 
8 Notes Towards A Hybrid Bestiary: Out of Apollinaire, Sutherland and others

George Szirtes

Tailpiece

Sarah Kay

Index

165 


\section{List of Illustrations}

1 Guillaume Apollinaire and Raoul Dufy, Le Bestiaire, 'Orphée’ 7

2 Guillaume Apollinaire and Raoul Dufy, Le Bestiaire, 'La Tortue' 8

3 Guillaume Apollinaire and Raoul Dufy, Le Bestiaire, 'Le Cheval' 9

4 Guillaume Apollinaire and Raoul Dufy, Le Bestiaire, 'Le Chat' 10

5 Guillaume Apollinaire and Raoul Dufy, Le Bestiaire, 'Le Poulpe' 11

6 Guillaume Apollinaire and Raoul Dufy, Le Bestiaire, 'Les Sirènes' 12

7 Guillaume Apollinaire and Raoul Dufy, Le Bestiaire, 'Ibis' 13

8 Guillaume Apollinaire and Raoul Dufy, Le Bestiaire, 'Le Bœuf' 14

9 Graham Sutherland, Bestiary, 'Orpheus' (1) 15

10 Graham Sutherland, Bestiary, 'Tortoise' 16

11 Graham Sutherland, Bestiary, 'Lion' 17

12 Graham Sutherland, Bestiary, 'Mouse' 18

13 Graham Sutherland, Bestiary, 'Elephant' 19

14 Graham Sutherland, Bestiary, 'Orpheus' (2) 20

15 Graham Sutherland, Bestiary, 'Fly' 21

16 Graham Sutherland, Bestiary, 'Orpheus' (3) 22

17 Graham Sutherland, Bestiary, 'Octopus' 23

18 Graham Sutherland, Bestiary, 'Sirens' 24

19 Graham Sutherland, Bestiary, 'Ibis' 25

20 Graham Sutherland, Bestiary, 'Pyre' 26

21 Guillaume Apollinaire, manuscript draft for the Bestiaire 44

22 Northumberland Bestiary, Adam naming the animals 48

23 Northumberland Bestiary, creation of humans and animals $\quad 49$

24 Clive Scott, graphic 1: 'Octopus' 82

25 Clive Scott, graphic 2: 'Ibis' 86

26 Clive Scott, graphic 3: 'Carp' 89

27 Music example 1: Louis Durey, 'La Chèvre du Thibet' 96

28 Music example 2: Francis Poulenc, 'La Chèvre du Thibet' 97

29 Gustave Soury, Dompteur Emmanuel with his cats 102

30 Charles Levy, circus poster 103 
31 Bestiary, British Library, Royal MS 12 C XIX, Manticore

111

32 Villard de Honnecourt, Sketchbook, Lion

33 Francis Bacon, Three Studies for Figures at the Base of a Crucifixion, right panel 


\section{Notes on contributors}

Dawn Ades is Professor Emerita at the University of Essex, a Fellow of the British Academy, a former trustee of the Tate and Professor of the History of Art at the Royal Academy, and was awarded a CBE in 2013 for her services to art history. She has been responsible for some of the most important exhibitions in London and overseas over the past 30 years, including Dada and Surrealism Reviewed (1978), Art in Latin America (1989), the Salvador Dalí centenary at the Palazzo Grassi in Venice (2004), The Colour of my Dreams: The Surrealist Revolution in Art at the Vancouver Art Gallery (2011) and Dalí/Duchamp at the Royal Academy (2017). She was Associate Curator for Manifesta 9 (2012). Her publications include standard works on photomontage, Dada, Surrealism, women artists and Mexican muralists.

Sarah Kay teaches French, comparative literature and medieval studies at New York University. A former Fellow of the British Academy, she has written widely on medieval texts across genres and languages, particularly on poetry and its connections with philosophy and literary theory. Her most recent books are Animal Skins and the Reading Self in Medieval Latin and French Bestiaries, and Philology's Vomit: An Essay on the Immortality and Corporeality of Texts (both 2017); her current work is on medieval song from Aristotle to opera.

Timothy Mathews is Emeritus Professor of French and Comparative Criticism at University College London. In his writing and translating he explores what relating to art can tell us about relating to people. His interests include relations of literary and visual art, translation and creative critical writing. He has written on many modern artists and writers, notably Apollinaire; his most recent monograph is Alberto Giacometti: the Art of Relation (2013). He is currently completing a book of creative critical chronicles and preparing a translation of Guillaume Apollinaire's La Femme assise. He is a member of the Academy of Europe and Officier dans l'Ordre des Palmes Académiques. 
Rachel Mundy is Assistant Professor of Music in the Arts, Culture and Media programme at Rutgers University in Newark. She specialises in twentieth-century music at the juncture of sound studies, the history of science and animal studies. Her book Animal Musicalities traces histories of modern sound through comparisons between animal and human musicality, drawing on the history of biology, anthropology, psychology and comparative musicology. Her current research explores the place of animal voices in modern narratives of environmental crisis.

Clive Scott is Professor Emeritus of European Literature at the University of East Anglia and a Fellow of the British Academy. His research interests lie in comparative poetics, in the relationship between photography and language, and in the experimental translation of poetry (see Literary Translation and the Rediscovery of Reading (2012), Translating the Perception of Text: Literary Translation and Phenomenology (2012) and Translating Apollinaire (2014)). His most recent book, The Work of Literary Translation, was published in 2018. He is at present preparing a set of studies entitled 'Dialogue, Movement, Rhythm: Essays in the Philosophy of Literary Translation'.

Matthew Senior is Ruberta T. McCandless Professor and Chair of the Department of French and Italian at Oberlin College. He has edited three collections of essays in the field of animal studies: Animots: Postanimality in French Thought, co-edited with David Clark and Carla Freccero (2015); A Cultural History of Animals in the Age of Enlightenment (2007); and Animal Acts: Configuring the Human in Western History from the Middle Ages to the Present, co-edited with Jennifer Ham (1997). He is also the author of In the Grip of Minos: Confessional Discourse in Dante, Corneille, and Racine (1994).

Sarah Spence is Distinguished Professor Emerita of Classics and Comparative Literature at the University of Georgia. Her work has focused both on the ancient poet Vergil and on the process of poetic adaptation and reception of the classics. She is the author of three monographs and several edited volumes including Poets and Critics Read Vergil, which features poets in conversation with Vergilians. She has served as editor-inchief of three journals: Literary Imagination, Vergilius and Speculum. In 2014, with Elizabeth Wright and Andrew Lemons, she published a translation and commentary of Vergilian Latin poems written about the 1571 Battle of Lepanto. She is currently working on a book on the poetic treatment of the island of Sicily and the adaptation of the myth of Proserpina in works from Cicero to Dante. 
George Szirtes is a Hungarian-born poet who came to England with his parents after the 1956 Budapest uprising. His attention to shape and sound, cultivated through his background in visual art and his bilingual upbringing, quickly led to his successful embrace of formal verse. His first book, The Slant Door (1979), won the Faber Memorial Prize; Bridge Passages (1991) was shortlisted for the Whitbread Poetry Prize; Reel (2004) won the T.S. Eliot Prize; and his New and Collected Poems was published by Bloodaxe in 2008. Since his first return to Hungary in 1984, Szirtes has translated, edited and anthologised numerous collections of Hungarian poetry, winning several awards including the Dery Prize for Imre Madach's The Tragedy of Man (1989), and the European Poetry Translation Prize for Zsuzsa Rakovsky's New Life (1994). His own work has been translated into numerous languages and widely anthologised, including in Penguin's British Poetry Since 1945. Szirtes has written extensively for radio and is the author of more than a dozen plays, musicals, opera libretti and oratorios, as well as of Exercise of Power (2001), a critical study of the artist Ana Maria Pacheco; he also co-edited New Writing 10 (2001) with Penelope Lively and collaborated with his wife, the painter Clarissa Upchurch, on Budapest: Image, Poem, Film (2006). He is a one-time member of the advisory panel of the British Centre for Literary Translation, and has been on the advisory board of the Poetry Book Society. He has been a member of the Royal Society of Literature since 1982. 



\section{Acknowledgements}

We would first of all like to thank all the contributors to this volume. We came together at our symposium held at NYU-London in 2017, and a spirit of conviviality, openness and free exchange seemed immediately to envelop us all. It has continued along the road to the production of this book. We would also like very warmly to thank the staff at NYULondon and the Department of French Literature, Thought and Culture, NYU, for their help with the symposium, and Henrietta Simson for her invaluable work securing the images you will find here.

We would like especially to thank the following for their generous financial support of the project in all its various aspects: the Department of French Literature, Thought and Culture, NYU; the Provost's Global Research Initiatives, NYU; the Humanities Center, NYU; and the Society for French Studies.

Finally, as an assorted group we would like once again to honour those to whom the book is dedicated, for they continue to fascinate, charm and challenge with their devotion to the embeddedness of art in life: Guillaume Apollinaire, Raoul Dufy and Graham Sutherland.

Sarah Kay

Timothy Mathews 



\title{
Headpiece: Oblique and prolonged Timothy Mathews
}

\author{
Le tact est relatif mais la vue est oblongue \\ Touching is relating but seeing is prolonged \\ Guillaume Apollinaire, 'Le Larron'
}

This collection of writing is a collection of voices all responding to the power of art. Its entry point is the response of artists to each other, which is the beginning of these artists' invitation to their viewers and readers. In 1979, why would Graham Sutherland spend some of the last months of his life creating new images in response to poems Guillaume Apollinaire wrote in 1911? Why did it become important to him to breathe another life into these poems? They were written as a bestiary, and what echoes and tones might have been swimming around in Apollinaire's mind as he engaged with that tradition, in yet another of his attempts to span the old and the new? How do Raoul Dufy's woodcuts contribute to the chorus, and what sort of book was made in 1911 by his pictures and Apollinaire's poems together? And what do we see now in Dufy's woodcuts, now that Sutherland's procession of aquatints has dismissed them from view?

There is something silent about engaging with any image, just like there is about reading, and bringing the two together creates still more ways of talking about voices that are silenced. But the gathering of voices in the pieces in this volume developed through various pairings and groupings, and as the individuals involved became taken up in the effects of Sutherland's images. The intimate space of the Prints and Drawings Room in Tate Britain as well as the gallery's staff provided privileged moments in which conversations charged off in many different directions, and for myself I felt that Sutherland's image-making was a springboard into what stays quiet within each one of us and reappears or disappears in all sorts of fits and starts. 
There was a literal dimension to that play of burial and emergence. Graham Sutherland's The Bestiary or the Procession of Orpheus has not been exhibited since its opening show at the Marlborough Gallery in 1979, and when I first invited Sarah Kay to come and have a look with me, at a time when I was learning the meaning of the word trauma in ways that have not left me, I felt as though a journey was beginning in which these images were being brought back to light, or at least to the eyes of more people. I have since discovered that such journeys in and out of the buried themselves express something of the character and mystery of Sutherland's art. Moreover, other than in the Marlborough Gallery publication accompanying the original show, Apollinaire's poems have not been placed together with Sutherland's responses to them, and there were technical, disciplinary, as well as personal and affective journeys involved in putting them back together again. There were also many national and historical border crossings to be negotiated as we all tried to see whether anything appears of a dialogue between Sutherland and Dufy, and between the bestiary of medieval times and the hostel it has provided down the ages for allegorical and fantastical wonderings.

There remained throughout something de-centred and unsettling about the enterprise, and a line began to emerge from the affective to the ethical. If to know is to know as one living person, what is there to prevent knowing from silencing the knowing of other living beings? With that question in mind, it was important - and is again now, as we bring all the pieces together here - to do everything we could to avoid thoughts of lineage, and do something other than trace things backwards and forwards along lines that might only confirm the outlook of the viewer, in that dance of revelation and disguise that clothed vulnerability, of which experience is often made and which seems receptive only to oblique lines of entry.

But with directness as well as obliqueness, Rachel Mundy approaches Apollinaire's poetic animals through Francis Poulenc's musical way of hearing them. In the spirit of Apollinaire, Poulenc's own musical animals were inspired by the menageries, circuses and story-books of his own midtwentieth-century Paris, slightly later than Apollinaire's. A lost natural history of animals explodes joyously from within the confines of modernist exoticism squeezed between the two world wars and the force of humancentred normalisation which it harbours. Expression interacts with suppression in an enigmatic and confusing ballet; perhaps for that reason translation has emerged in recent times as such a dominant metaphor, also an intuitive one, for the way thoughts travel, also feelings and impulses, and not least formal interdisciplinary anxieties. 
Clive Scott brings more of his pioneering work not only on Apollinaire, but also the practice of translation; the two are mutually creative. Under his hand, writing, translating, thinking, imagining, shaping and re-forming all combine. What he calls a 'metabolic' approach to composing poetry and translating allows him to open it out kinaesthetically. Through interpretation, association and the practice of the page, Scott produces a verbal-visual cornucopia and a 'zoo-poetics' out of his responses to Apollinaire's verse animals. Exploration hits against the confines which shape it, and hits back, and Mundy and Scott show the capacity of art to perform that dynamic.

Matthew Senior's sense of the lines, lineages and legacies mapped between Apollinaire, Dufy and Sutherland offers his own map-sketch in writing of fragile humanity. It is one of mechanisation and brutalisation, inseparable it seems from the impulses of life in human form. Reading Apollinaire, many of us seemed to feel that Dufy produces what look like emblems of an integration of the human and the animal: some capacity of humans to imagine the voices of all the world in a spirit of generosity. But in the implementation of art, Sutherland sees the animal world turned into a set of implements, and for Senior, Orpheus in his various guises in the procession which is Sutherland's bestiary can no longer speak the underworld languages of the soul, both human and animal. Now he sings the songs of alienated labour, organisms overwhelmed by their anatomy and messages of decay, vulnerability and body-on-body violence.

Sarah Spence's tangent is another way of evoking the history of the legend and the legacy that is Orpheus, battered by both heroism and tragedy. A poet laureate of nature and animals, Orpheus is co-opted for a moment into a war laureate anyone would want on their side in a battle to the death. Only later is Orpheus the poet of love, and a poet finally lost in melancholy and collapsed in doubt. Spence takes us on a journey from the temples at Delphi to the drama of Euripides, and to Augustan Rome, and she divines in Apollinaire's cameo of the ibis, itself a journey in miniature from magic to elegy. It is a journey in which loss and grief show their place in the fabric of life, and where the black ink in Dufy's woodcuts allow the images of the human-animal understanding to emerge. They are the shadows of death that allow human life to be. In a journey from Vergil and Ovid, with Dufy and Apollinaire, and from Max Jacob to Mark Strand, Spence draws the lines of poetry that illuminates the constraints of listening to the songs of disappearance.

And so what is a bestiary? What is a bestiary now? Sarah Kay returns to her pioneering work on bestiaries to answer the question 
again now. To do so through Apollinaire and Dufy working together is itself to tell a story of the temporal and cultural tapestries to which the bestiary bears witnesses. From Alexandria to sub-Saharan Africa and the Middle East and into Latin translations, the bestiary is handed on through medieval illuminations as a book made of text and pictures in which the reader is invited to reflect on the relations of human and animal life symbolic relations hovering between the natural and the scriptural. Kay sees that Apollinaire and Dufy are delving into the harmonics of the French medieval bestiary book and stretch its visual-verbal enigmas towards Orpheus - a procession of Orpheuses that gives their book its title and that Sutherland maintains. What is a procession? It sounds to me like an organised crowd punctuated by spaces and hiatuses which are hard to measure or read. It leads me to wonder how many Orpheuses are there and how many songs they might sing, and whether all these Orpheuses appear together in a crowd, or in a line going for a walk, as Paul Klee might say, bound who knows where? What do we hear when we listen to the songs of history and myth - once again, what songs of loss and life? Kay shows how these are questions of naming, questions of what is discovered about naming when man names animals, about what kinds of kinship, what kinds of relation between colonisation and discovery. Books of names and naming, but also imaging, each side by side with the other. Kay leads us to wonder about the ways in which medieval bestiary books of naming and illuminating, written on skin, reach out to be touched. What is the mobility of kinship? Mobility within kinship suggests freedom within laws, the freedom to understand laws and refashion them. But perhaps understanding simply changes shape over the time of forgetting?

Over disciplinary border crossings and the laws involved, implicit laws all the more active for that, the pieces collected here have all responded to some understanding of the power of art. The collection is its own procession of songs sung to the echoes of Orpheus. There is no congealed shape, but instead there is interaction, which as a group we have understood as respect for the hiatuses between all people and the lights that glimmer there. In responding to Apollinaire myself, I've always been struck by the lyricism he finds not only in the affective voices of the past but also in the energy of the present - his capacity to see one in the other. In these echoes Apollinaire also discovers the fragility of the social fabric made of generosity and violence. In The Bestiary, I was struck like others in our venture by the decorativeness that Apollinaire's short verses share with Dufy's woodcuts and their ease of passage between surface and depth, or by the way his wood cuts. But I found that 
Sutherland works with decorativeness to dismantle its defences and show the tyrannies it harbours. ' $I$ am this inhuman monster', Apollinaire writes, assuming the voice of all poets, charming the world to the sounds of the broken embraces which are only his to hear, the only ones he hears.

For the answer to any question is an answer spoken in the moment. What hope is there in the present to tell the old from the new, and freedom from its lures? These are questions without answers, but art offers ways to address them. George Szirtes has written a new bestiary especially for this book, one for today - an invitation to read all our various todays through the lens of a bestiary in which he responds to Sutherland's animal images as well as to the sounds of Apollinaire. His 'notes towards a hybrid bestiary' capture and adapt the quick, decorative capturing and adapting that characterise the bestiary and the way it comes to us now. 'Out of Apollinaire, Sutherland and others', Szirtes adds - how many others, and how many others lurk in those two voices, for to how many are they devoted? And to how many voices is even devotion deaf, leaving only the lovely appearances of hearing and discovering? Szirtes writes:

Son of Calliope hand us the keys

To the house of mysteries

Calliope is the muse of eloquence, but the house of mysteries to which she offers the keys is an endless dictionary whose pages flutter past like those of a scrapbook. For his bestiary, Szirtes not only writes a series of short verse poems to pictures, but also short prose poems to both. Together in some kind of loose community these sets capture something of what it is to try and capture, to translate on the fly the sights and sounds of 'where we live' as Szirtes evokes it, flippantly or despairingly trying to take in the shapelessness of history as it's lived by each one of us. Light-heartedness on the one hand, appropriation and violence on the other; melancholy drifts in both, while comet trails of pain assume the shapes of joy. And what a joy it was for all of us to come together over a series of words and images that, while inseparable, fail to coalesce, or to let go of their obstinate and capricious variety. At least some of that joy we hope is presented to readers here.

A word or two about illustrations and translations. George Szirtes' Notes Towards A Hybrid Bestiary is an integral piece: each page comprises verse poetry and prose poetic accompaniment, in dialogue with images of animals created by Sutherland and others. All images taken from the book by Apollinaire and Dufy, and from the portfolio by Sutherland in 
response to Apollinaire, are collected together on pages 7-26. There are also black and white reminders of these images included in the text at the points where authors address them. Graphics created by Clive Scott, musical examples referred to by Rachel Mundy and images from sources other than Apollinaire/Dufy or Sutherland are included in the essays that discuss them. Although originally titled Apollinaire, Le Bestiaire ou Cortège d'Orphée, Sutherland's portfolio is listed at the Tate as The Bestiary or the Procession of Orpheus, and in this book we refer to it by the translated title to distinguish it from the French one. Unless otherwise indicated, all other translations are provided by the authors themselves, producing variations which the editors wish to preserve and treasure, and which they hope readers will find illuminating. 


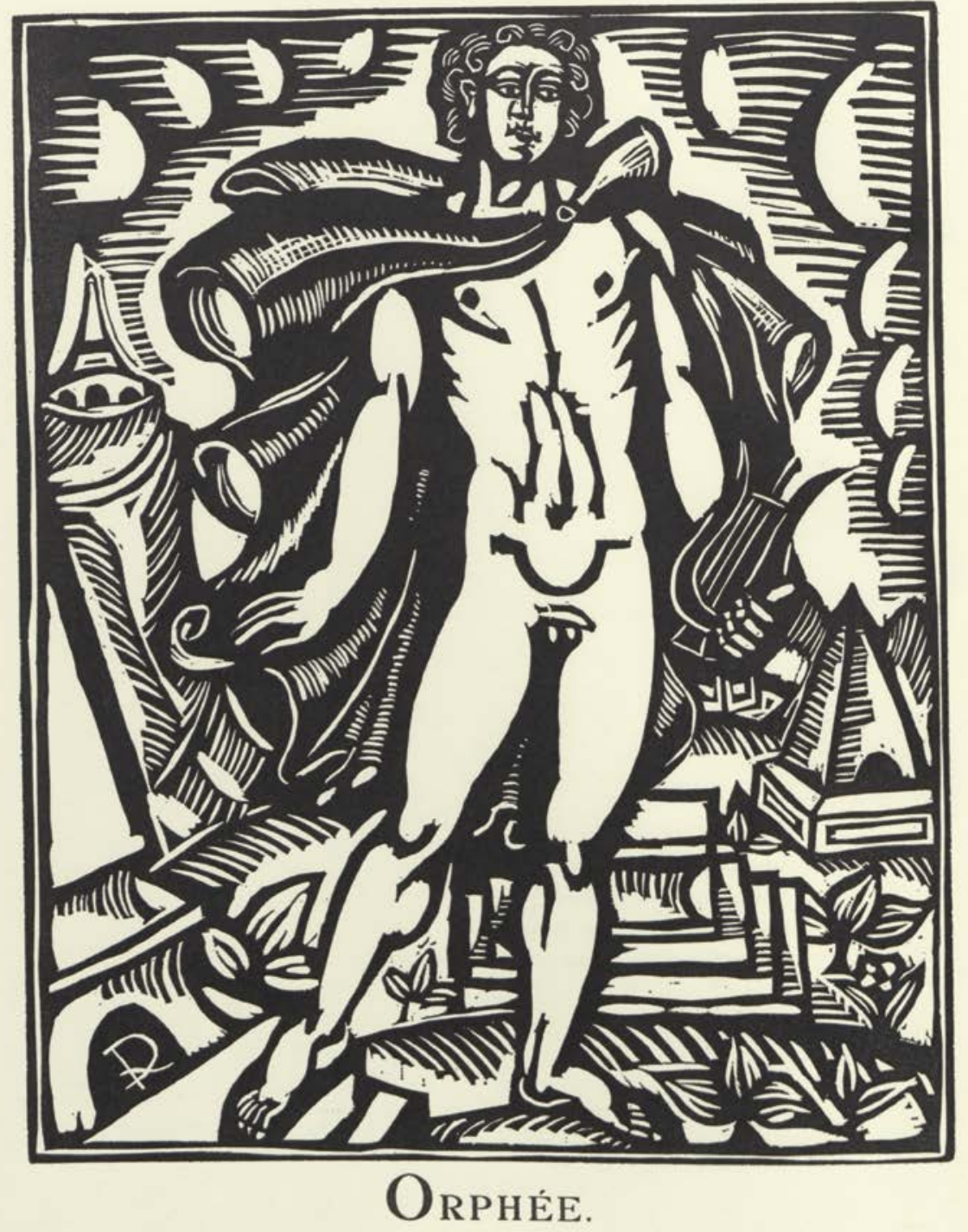

Illustration 1 Raoul Dufy, 'Orphée', 1911, (c) ADAGP, Paris and DACS, London 2019. Image copyright (C) The Metropolitan Museum of Art. Image source: Art Resource, New York 


\section{LA Tortue.}

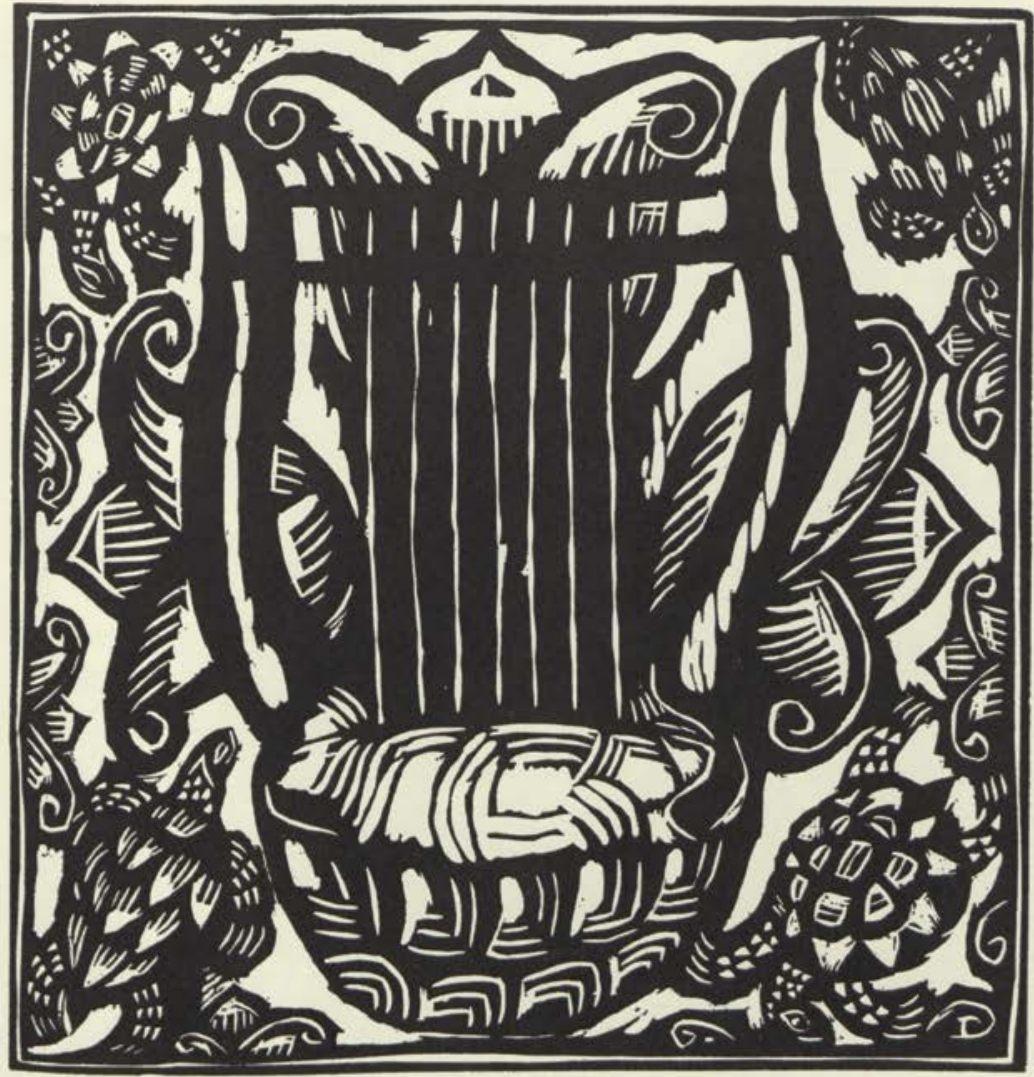

Du Thrace magique, ô délire!

Mes doigts sûrs font sonner la lyre.

Les animaux passent aux sons

De ma tortue, de mes chansons.

Illustration 2 Raoul Dufy, 'La Tortue', 1911, (C) ADAGP, Paris and DACS, London 2019. Image copyright (C) The Metropolitan Museum of Art. Image source: Art Resource, New York 


\section{Le Cheval.}

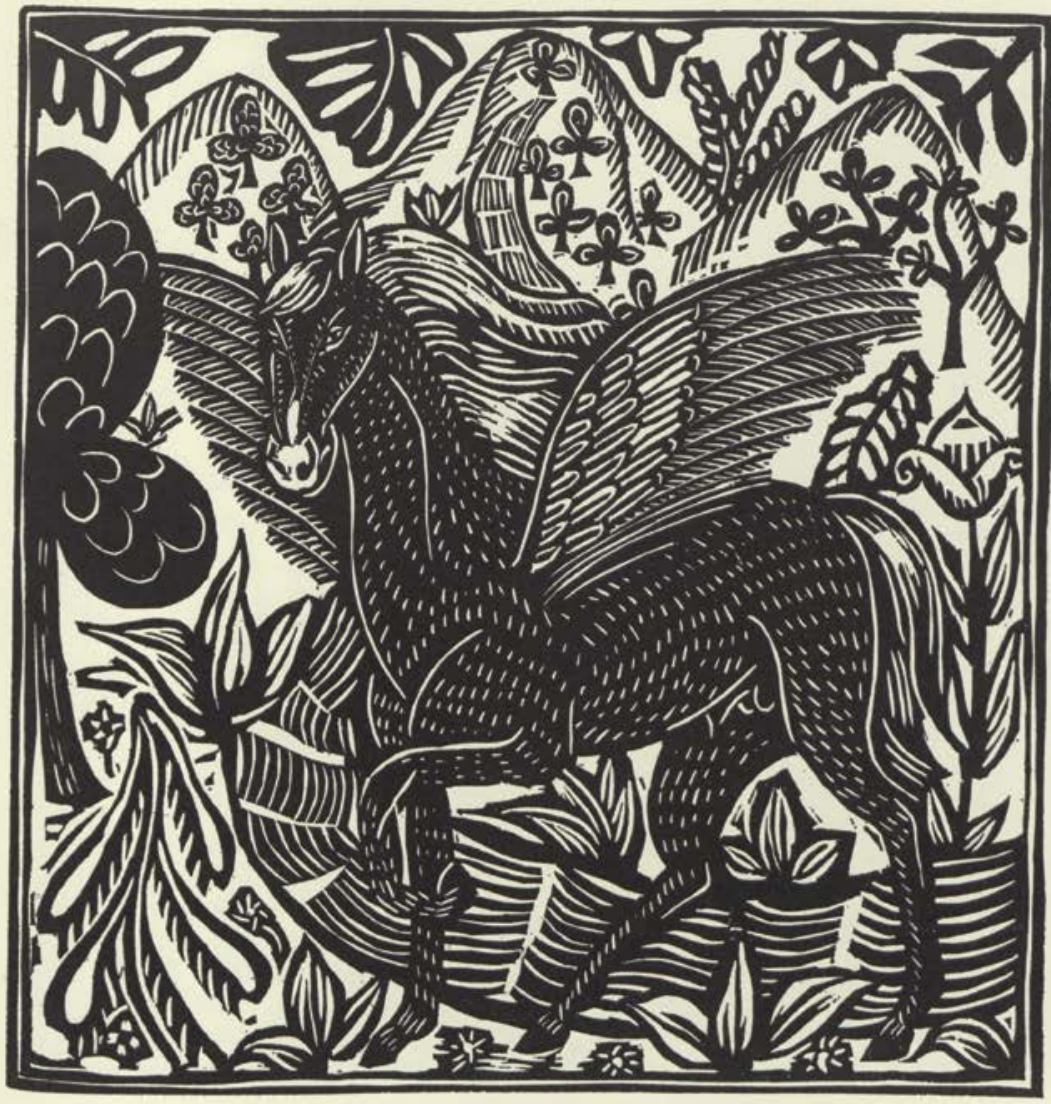

Mes durs rêves formels sauront te chevaucher,

Mon destin au char d'or sera ton beau cocher

Qui pour rênes tiendra tendus à frénésie,

Mes vers, les parangons de toute poésie.

Illustration 3 Raoul Dufy, 'Le Cheval', (C) ADAGP, Paris and DACS, London 2019. Image copyright (C) The Metropolitan Museum of Art. Image source: Art Resource, New York 


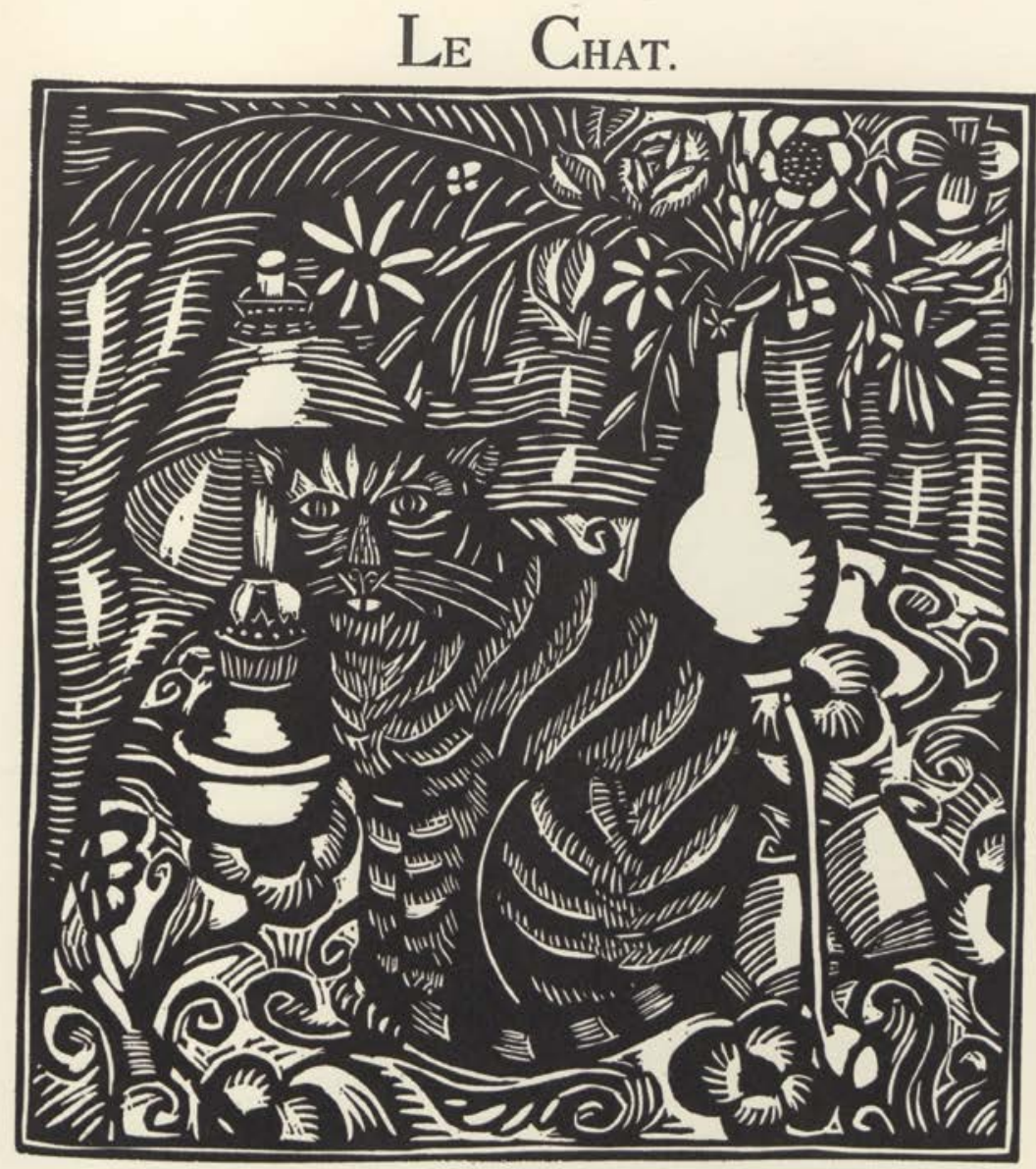

Je souhaite dans ma maison :

Une femme ayant sa raison,

Un chat passant parmi les livres,

Des amis en toute saison

Sans lesquels je ne peux pas vivre.

Illustration 4 Raoul Dufy, 'Le Chat', (C) ADAGP, Paris and DACS, London 2019. Image copyright (C) The Metropolitan Museum of Art. Image source: Art Resource, New York 


\section{Le Poulpe.}

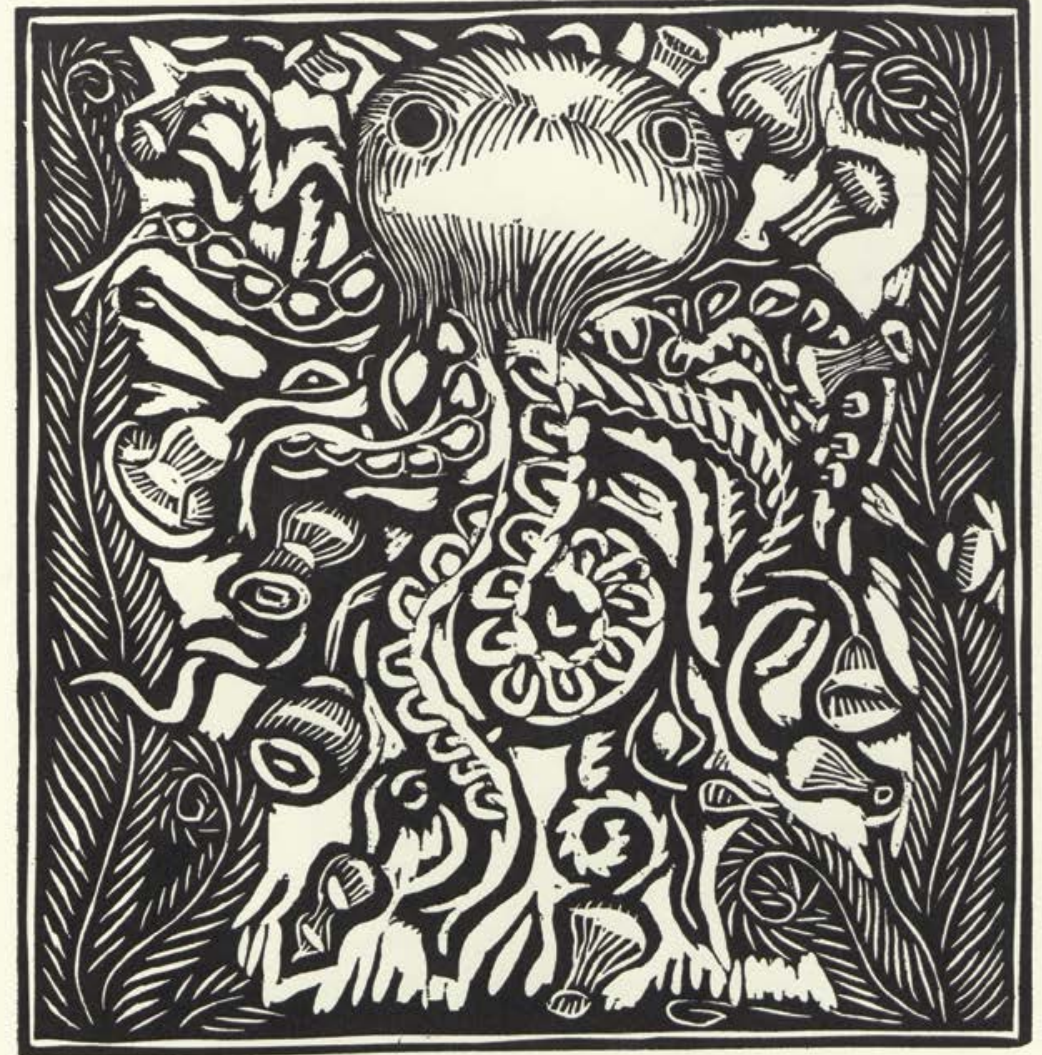

Jetant son encre vers les cieux, Suçant le sang de ce qu'il aime Et le trouvant délicieux,

Ce monstre inhumain, c'est moi-même.

Illustration 5 Raoul Dufy, 'Le Poulpe', 1911, (C) ADAGP, Paris and DACS, London 2019. Image copyright (C) The Metropolitan Museum of Art. Image source: Art Resource, New York 


\section{Les Sirènes.}

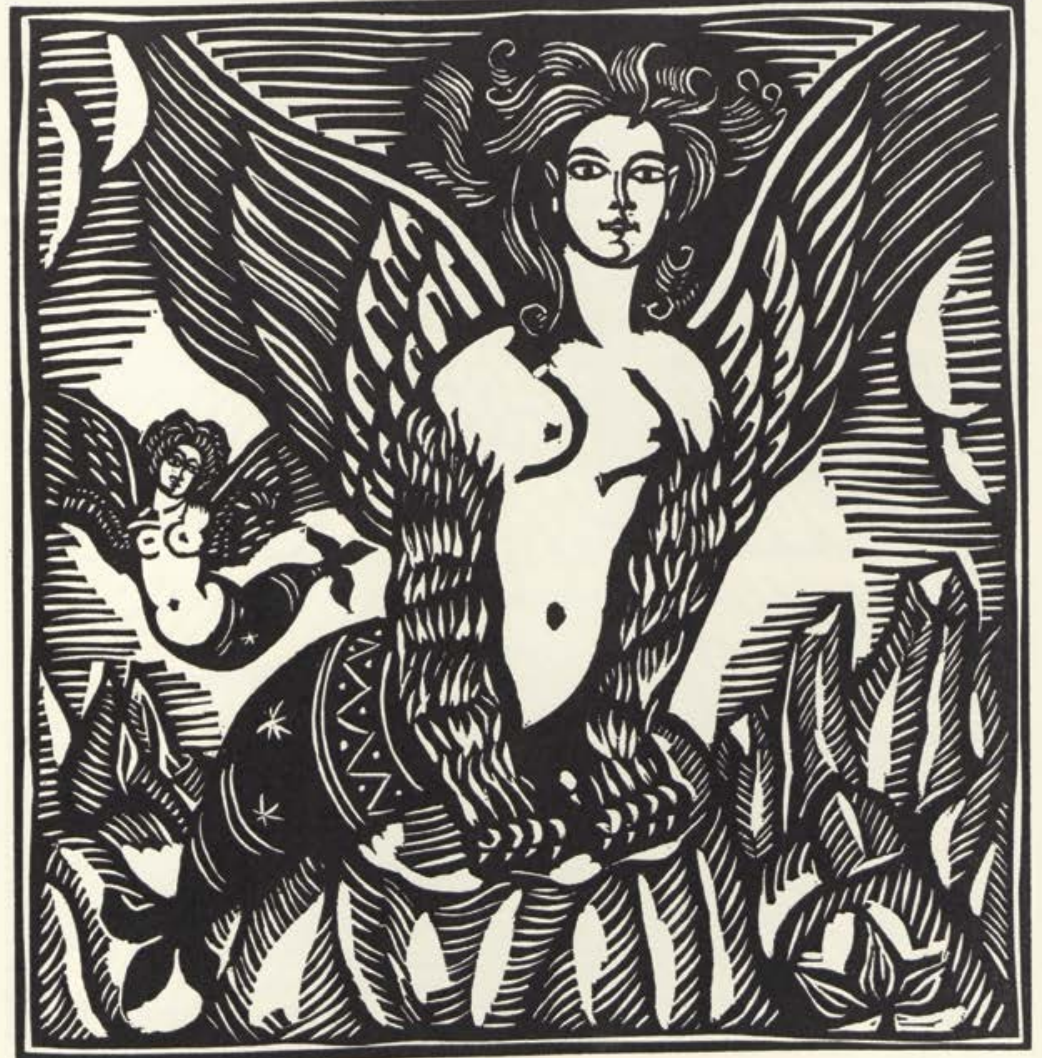

Sachè-je d'où provient, Sirènes, votre ennui Quand vous vous lamentez, au large, dans la nuit? Mer, je suis, comme toi, plein de voix machinées Et mes vaisseaux chantants se nomment les années.

Illustration 6 Raoul Dufy, 'Les Sirènes', 1911, @ ADAGP, Paris and DACS, London 2019. Image copyright (C) The Metropolitan Museum of Art. Image source: Art Resource, New York 


\section{IBIS.}

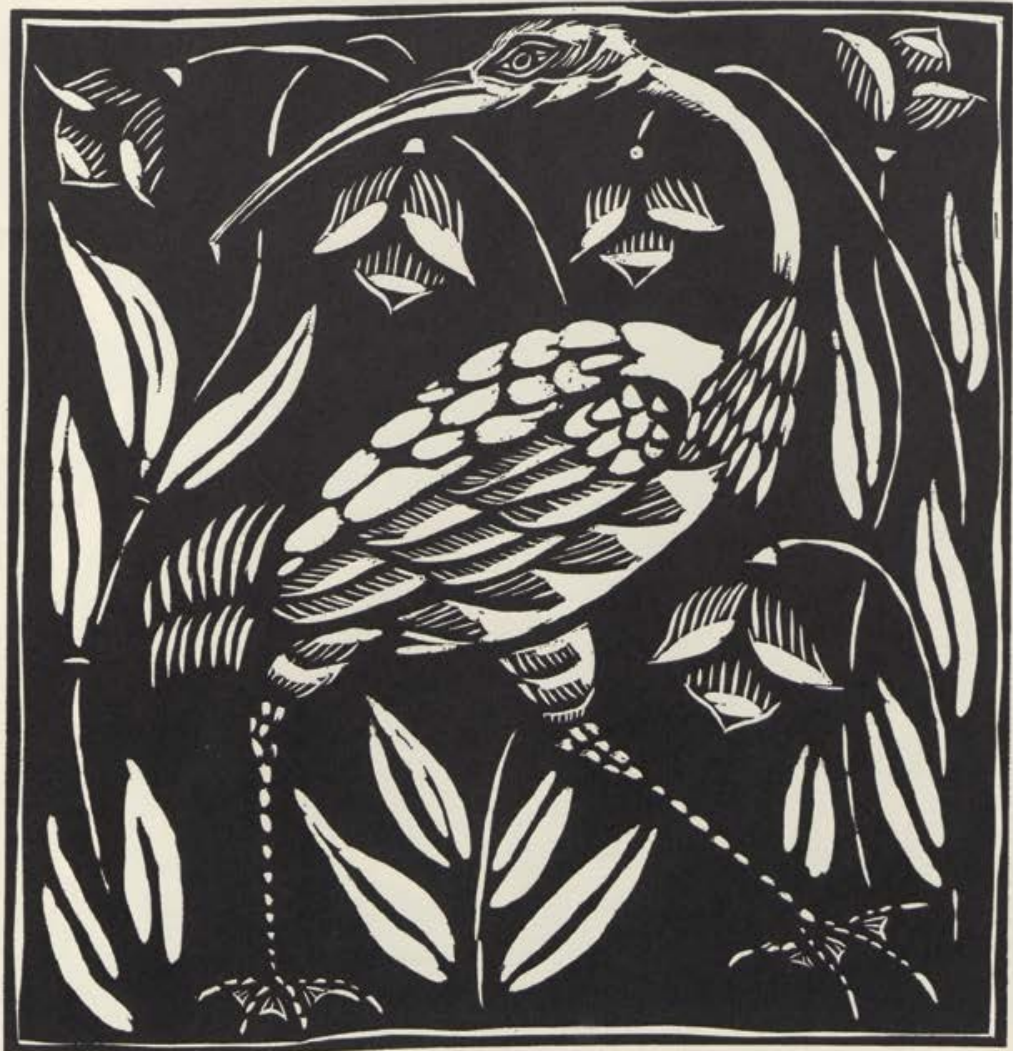

Oui, jirai dans l'ombre terreuse.

O mort certaine, ainsi soit-il !

Latin mortel, parole affreuse,

Ibis, oiseau des bords du Nil.

Illustration 7 Raoul Dufy, 'Ibis', 1911, (C) ADAGP, Paris and DACS, London 2019. Image copyright (C) The Metropolitan Museum of Art. Image source: Art Resource, New York 


\section{Le Boeuf.}

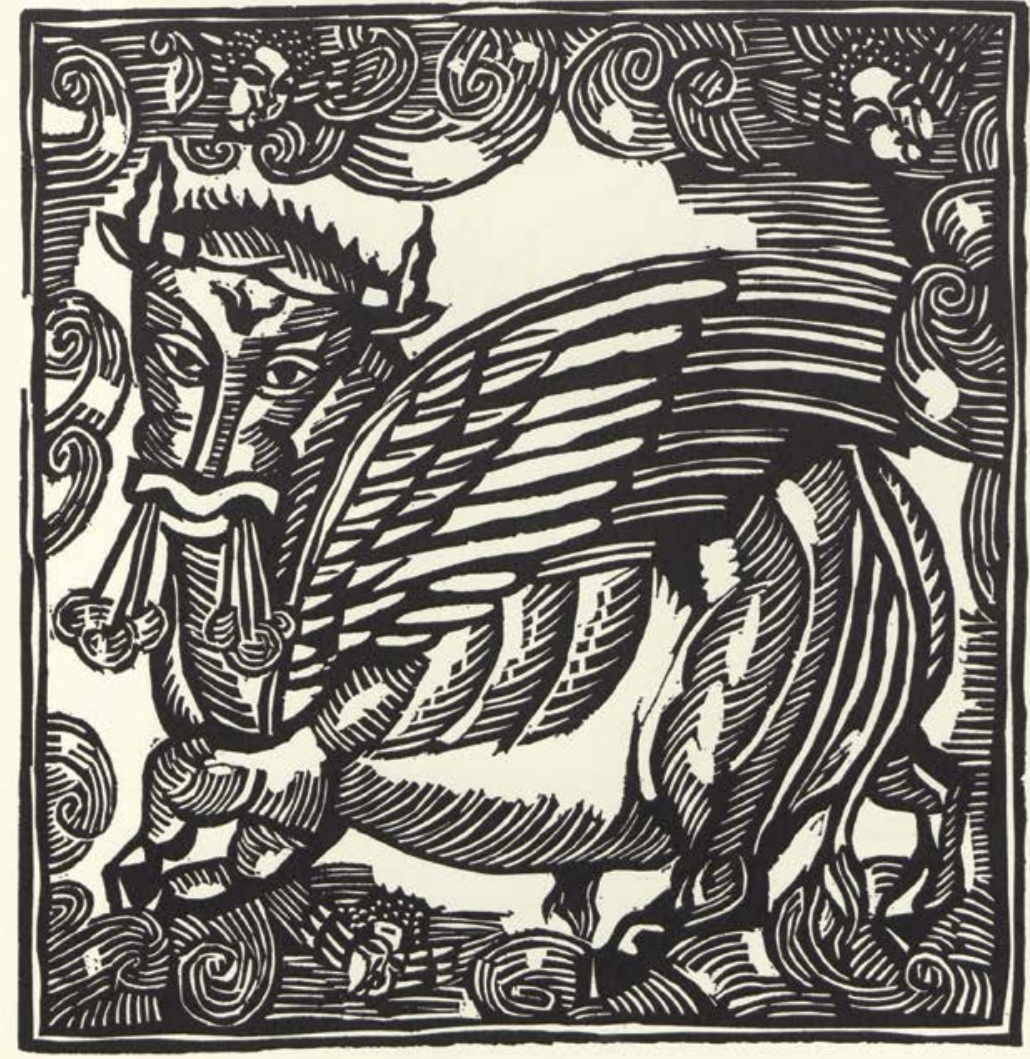

Ce chérubin dit la louange

Du paradis, où, près des anges,

Nous revivrons, mes chers amis

Quand le bon Dieu l'aura permis.

Illustration 8 Raoul Dufy, 'Le Bœuf', 1911, @ ADAGP, Paris and DACS, London 2019. Image copyright (C) The Metropolitan Museum of Art. Image source: Art Resource, New York 


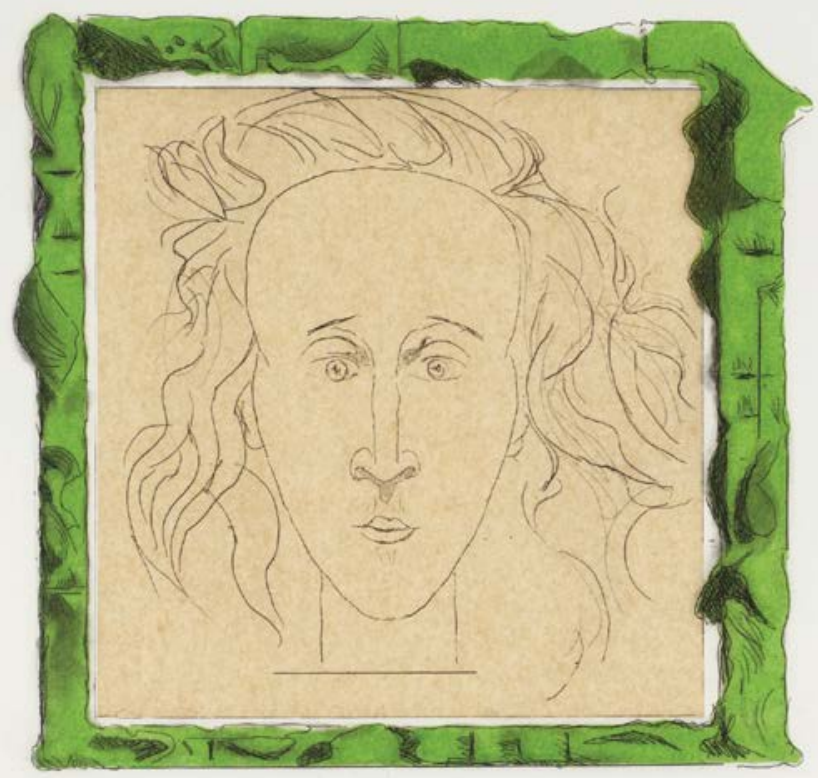

Illustration 9 Graham Sutherland, OM, from The Bestiary or the Procession of Orpheus, 1. 'Orpheus', 1978-9. (C) Estate of Graham Sutherland. Photo (C) Tate 


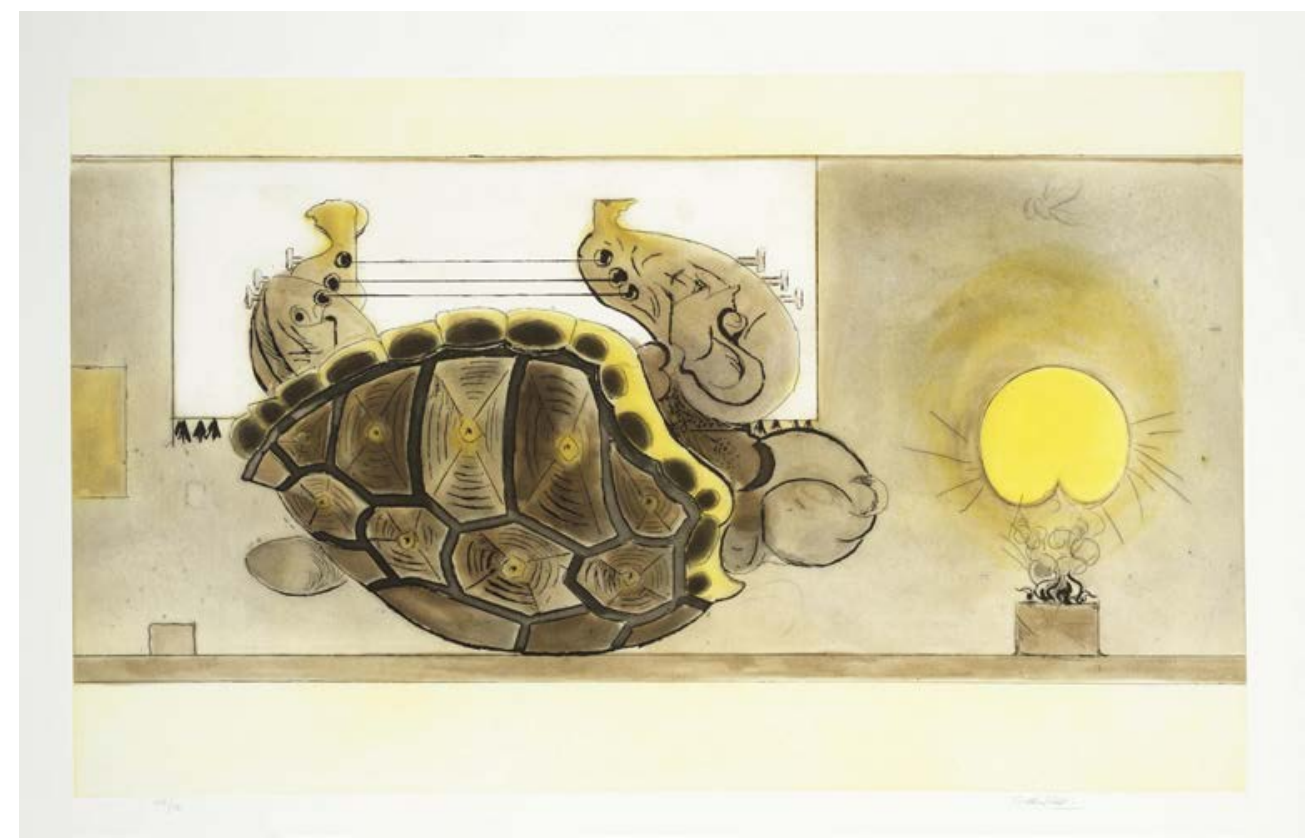

Illustration 10 Graham Sutherland, OM, from The Bestiary or the Procession of Orpheus, 2. 'The Tortoise', 1978-9. (C) Estate of Graham Sutherland. Photo (C) Tate 


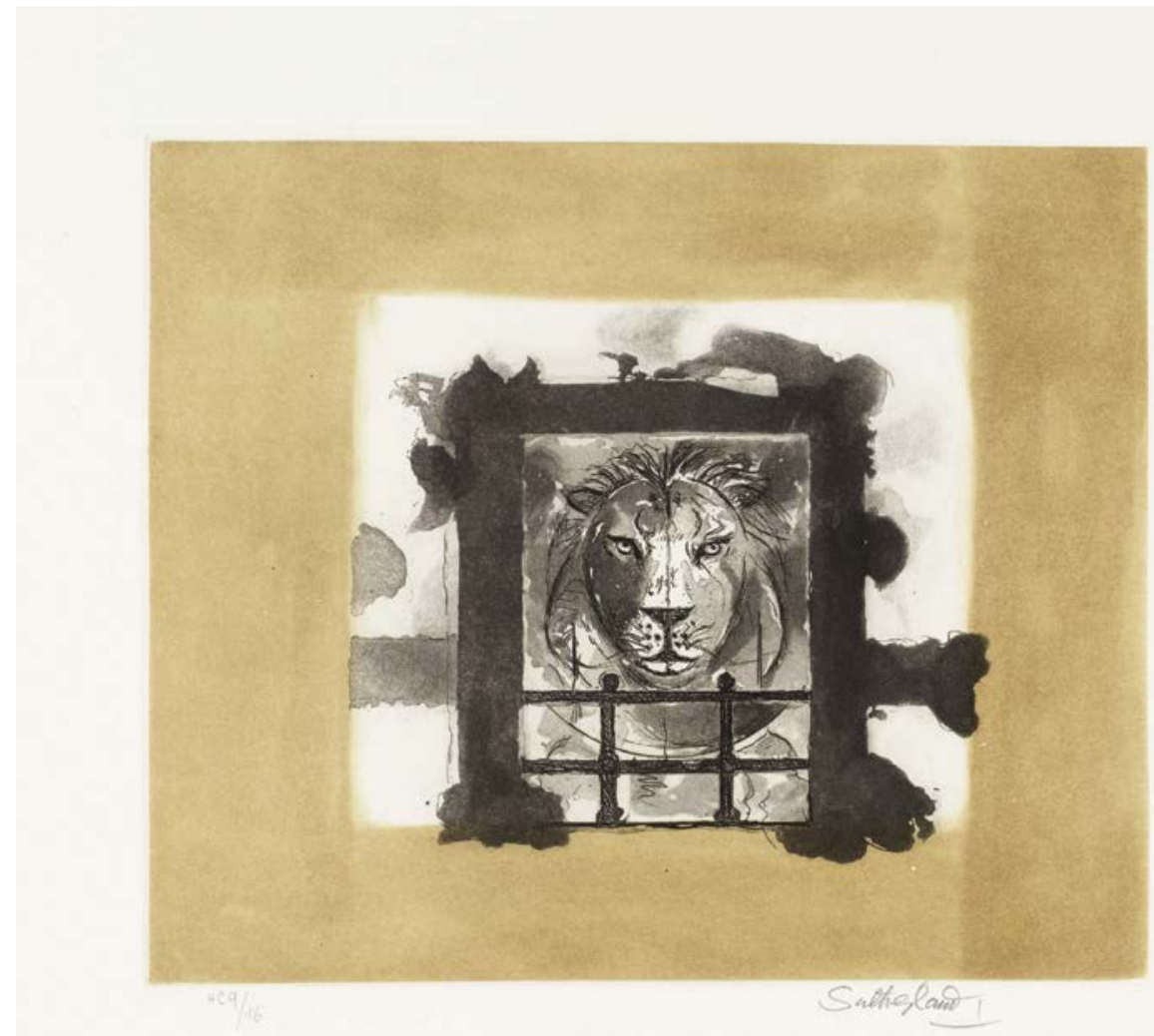

Illustration 11 Graham Sutherland, OM, from The Bestiary or the Procession of Orpheus, 3. 'The Lion', 1978-9. (C) Estate of Graham Sutherland. Photo (C) Tate 


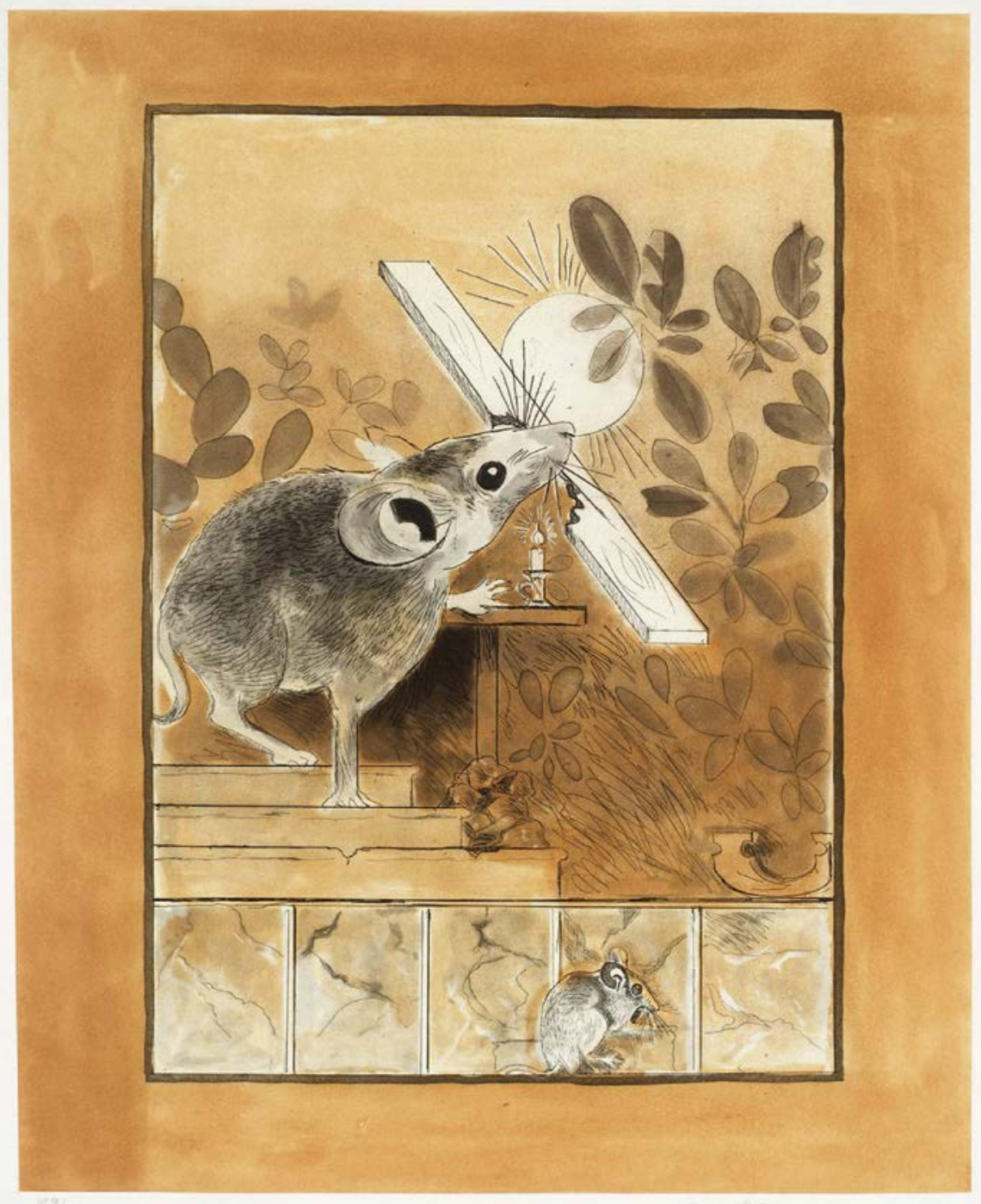

Illustration 12 Graham Sutherland, OM, from The Bestiary or the Procession of Orpheus, 5. 'The Mouse', 1978-9. (C) Estate of Graham Sutherland. Photo (c) Tate 


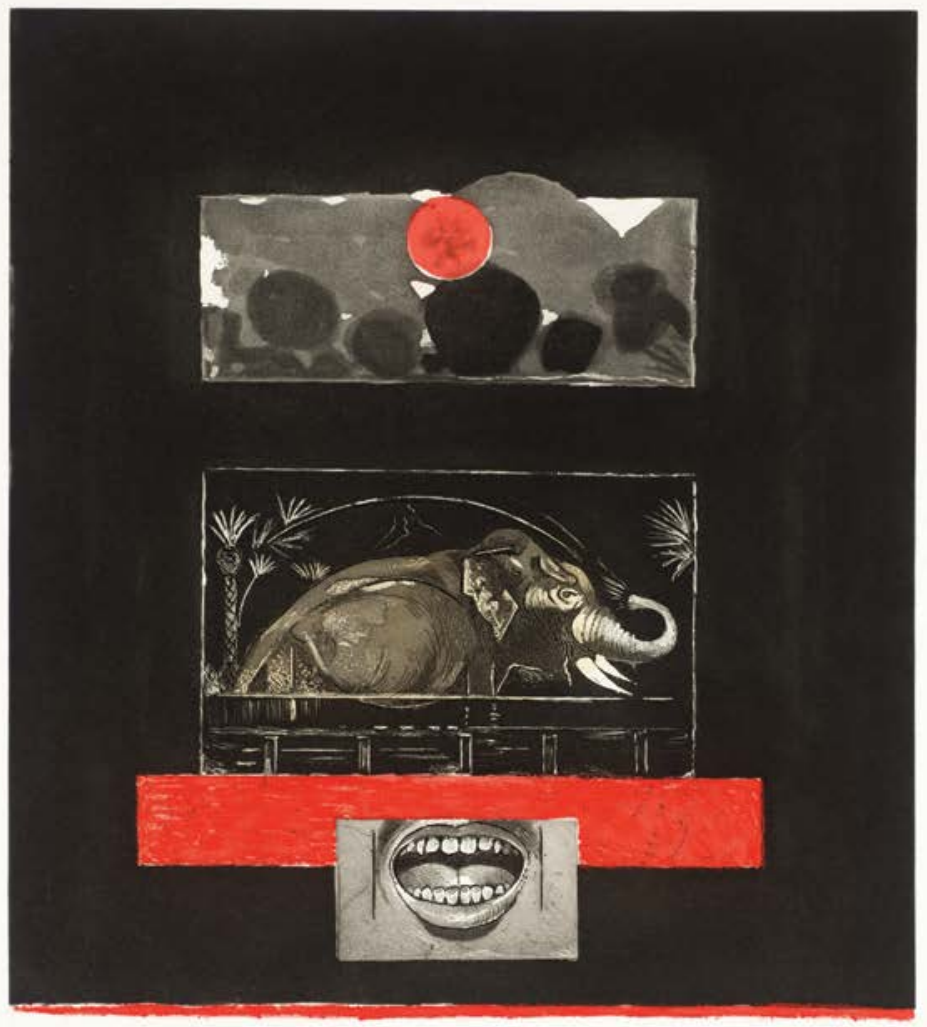

Illustration 13 Graham Sutherland, OM, from The Bestiary or the Procession of Orpheus, 6. 'The Elephant', 1978-9. (C) Estate of Graham Sutherland. Photo (C) Tate 


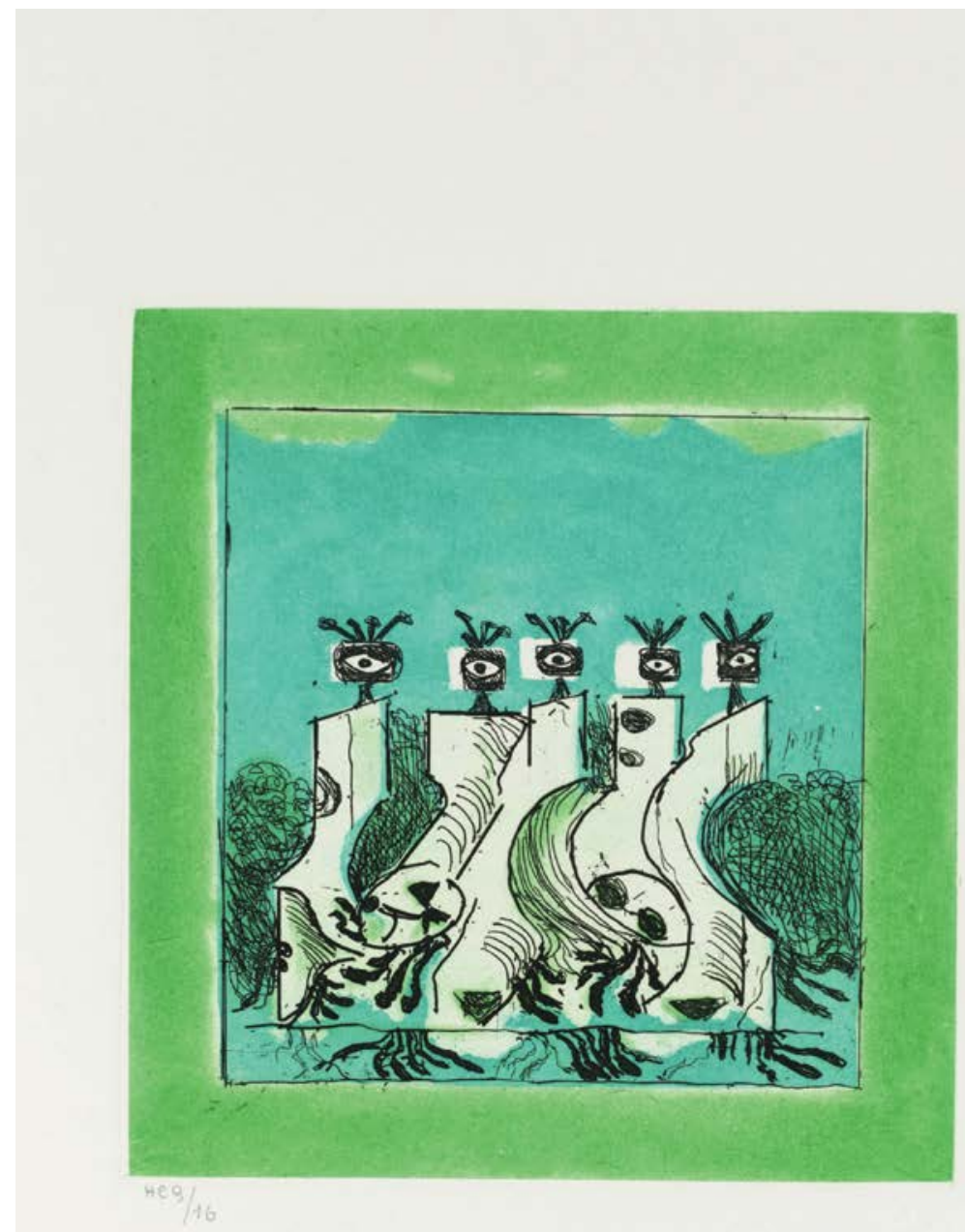

Illustration 14 Graham Sutherland, OM, from The Bestiary or the Procession of Orpheus, 7. 'Orpheus', 1978-9. (c) Estate of Graham Sutherland. Photo (C) Tate 


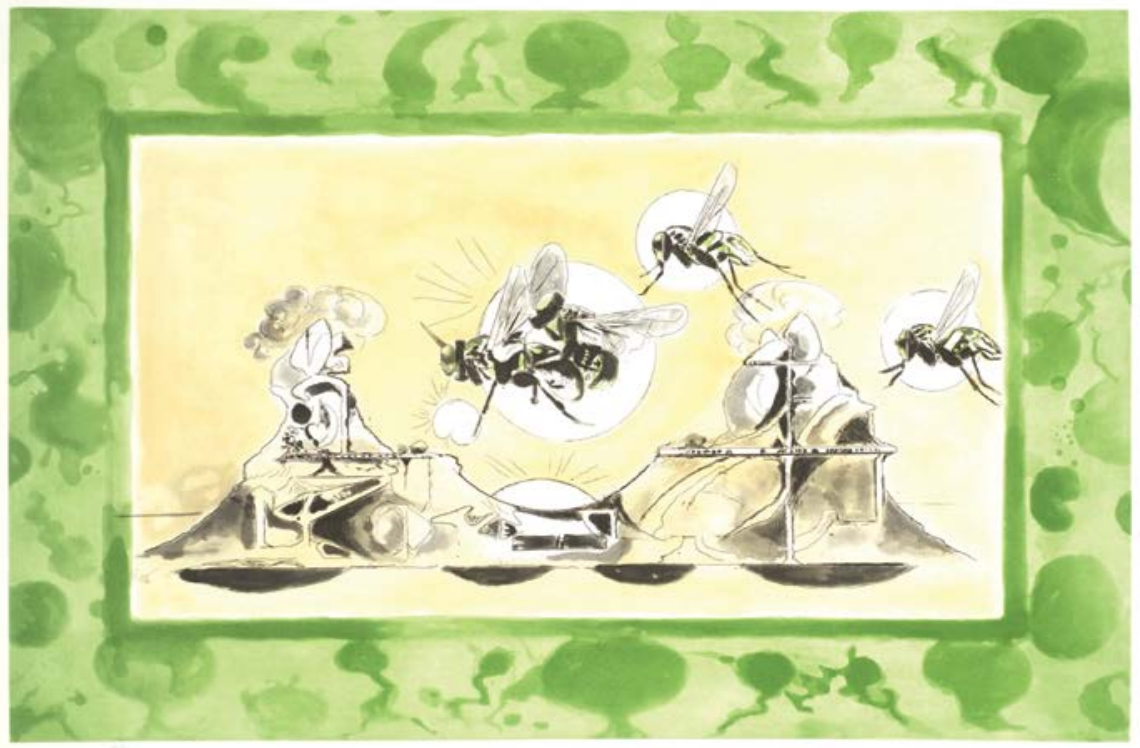

Illustration 15 Graham Sutherland, OM, from The Bestiary or the Procession of Orpheus, 9. 'The Fly', 1978-9. (C) Estate of Graham Sutherland. Photo (C) Tate 


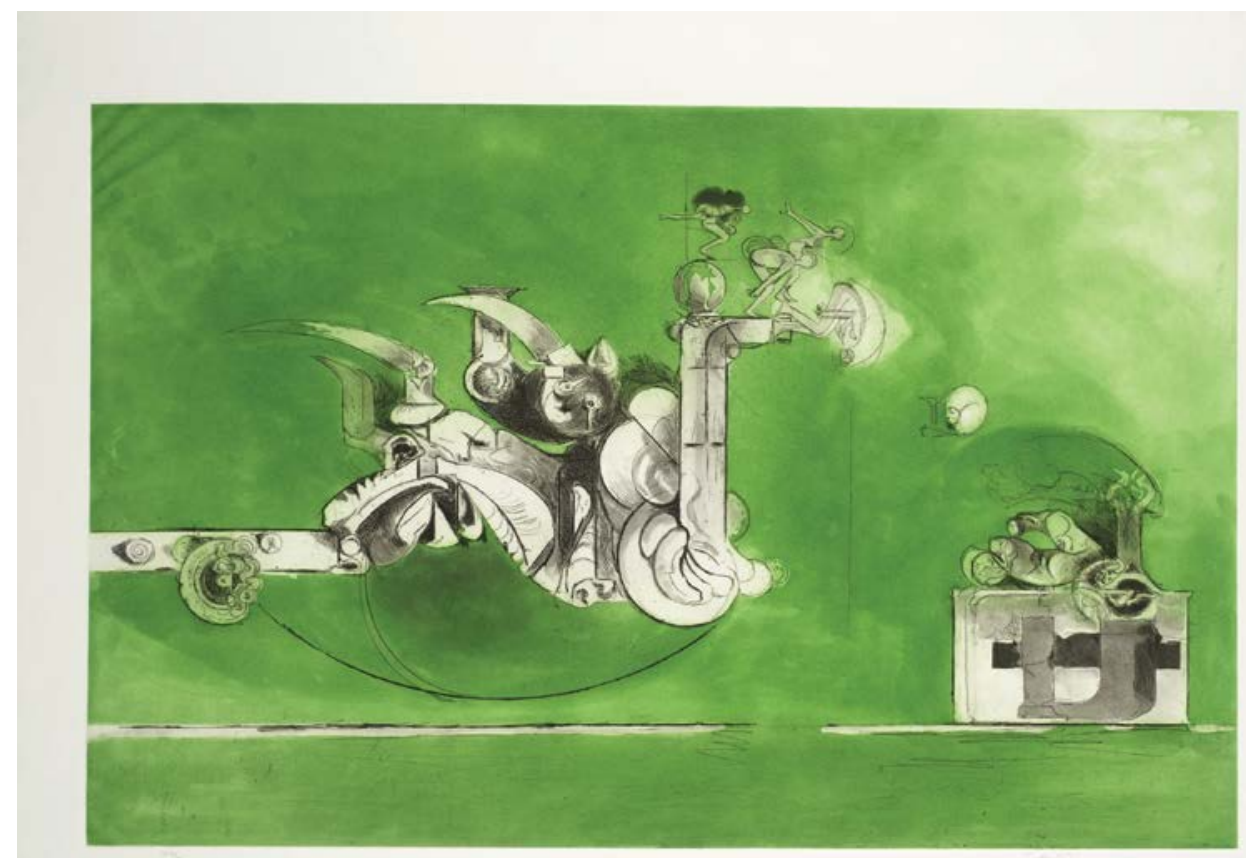

Illustration 16 Graham Sutherland, OM, from The Bestiary or the Procession of Orpheus, 12. 'Orpheus', 1978-9. (C) Estate of Graham Sutherland. Photo (c) Tate 


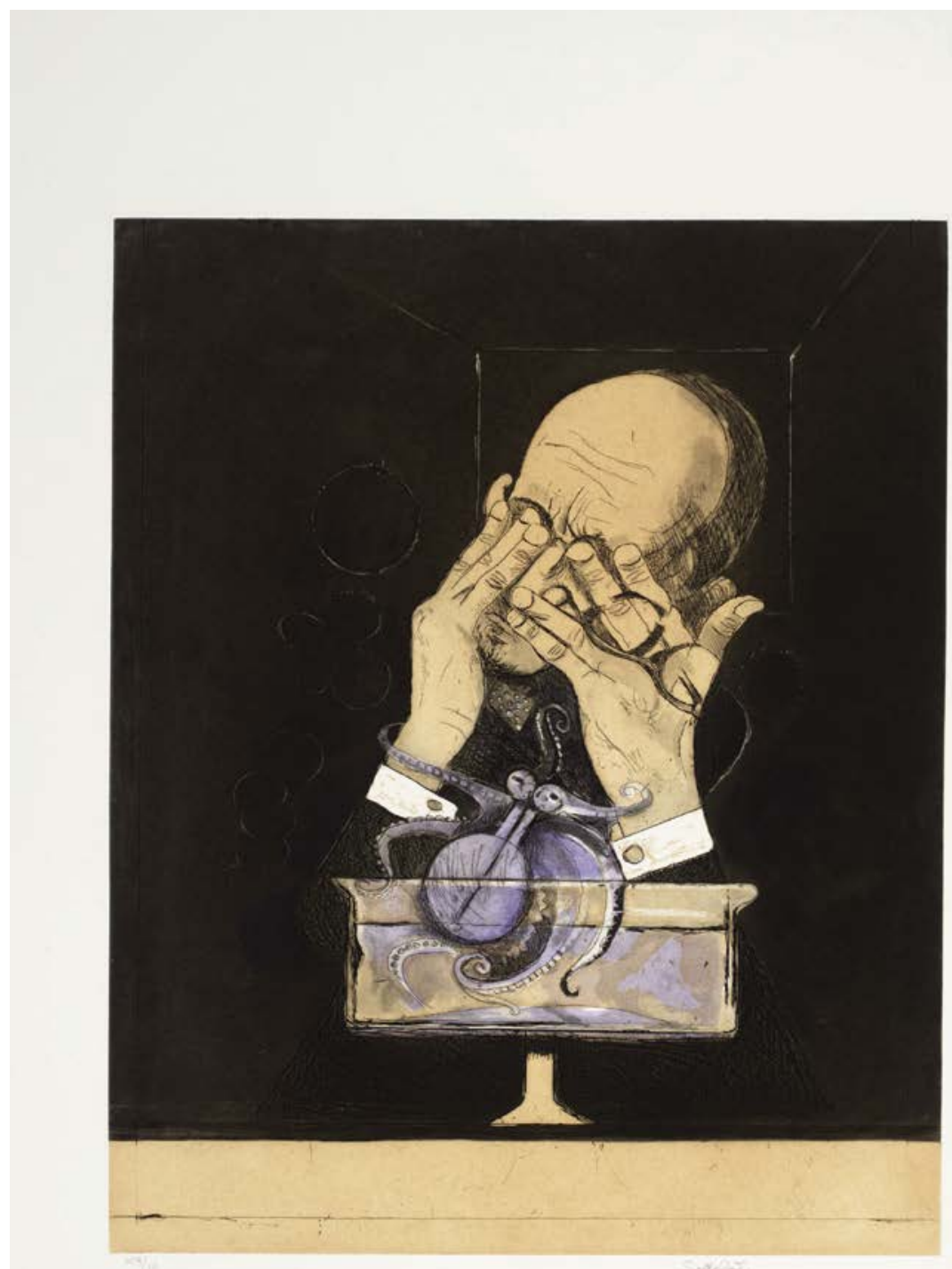

Illustration 17 Graham Sutherland, OM, from The Bestiary or the Procession of Orpheus, 13. 'The Octopus', 1978-9. (C) Estate of Graham Sutherland. Photo (c) Tate 


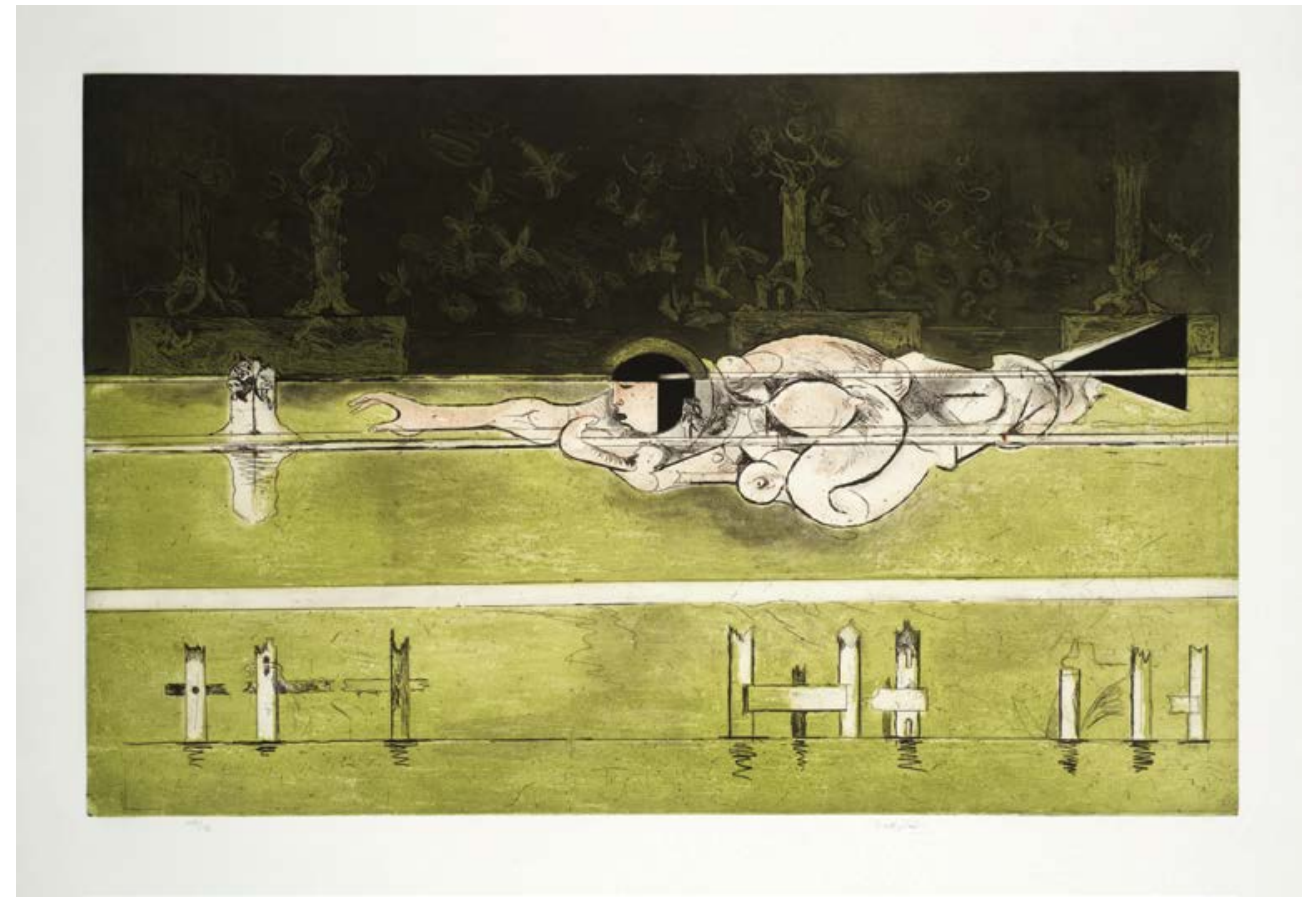

Illustration 18 Graham Sutherland, OM, from The Bestiary or the Procession of Orpheus, 14. 'The Sirens', 1978-9. (C) Estate of Graham Sutherland. Photo (C) Tate 


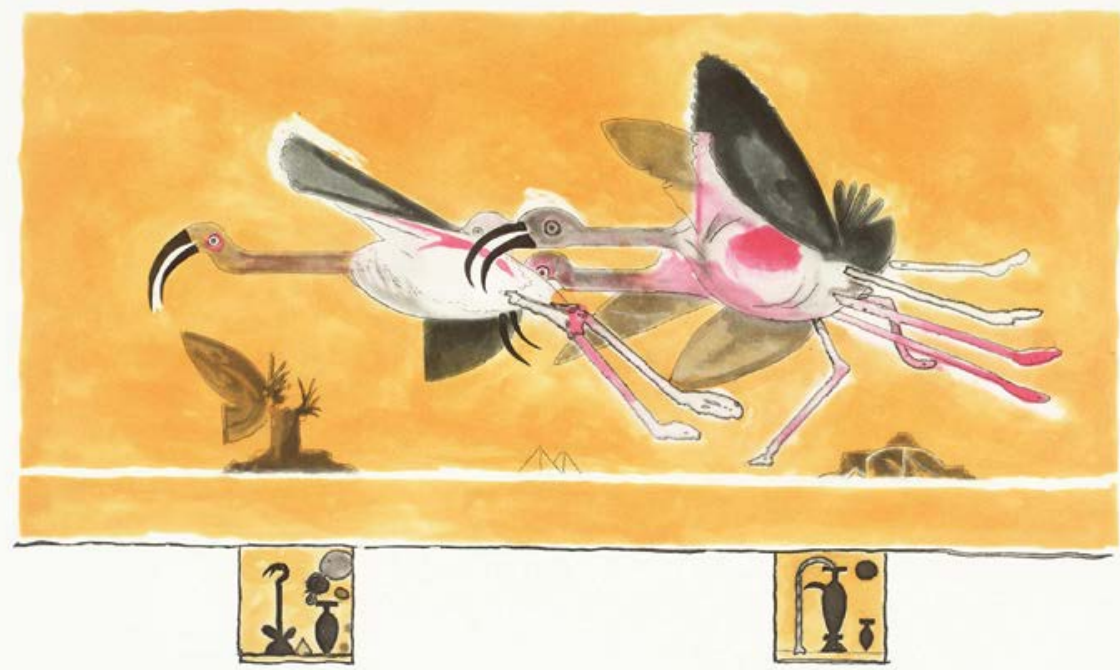

Illustration 19 Graham Sutherland, OM, from The Bestiary or the Procession of Orpheus, 15. 'Ibis', 1978-9. (C) Estate of Graham Sutherland. Photo (C) Tate 


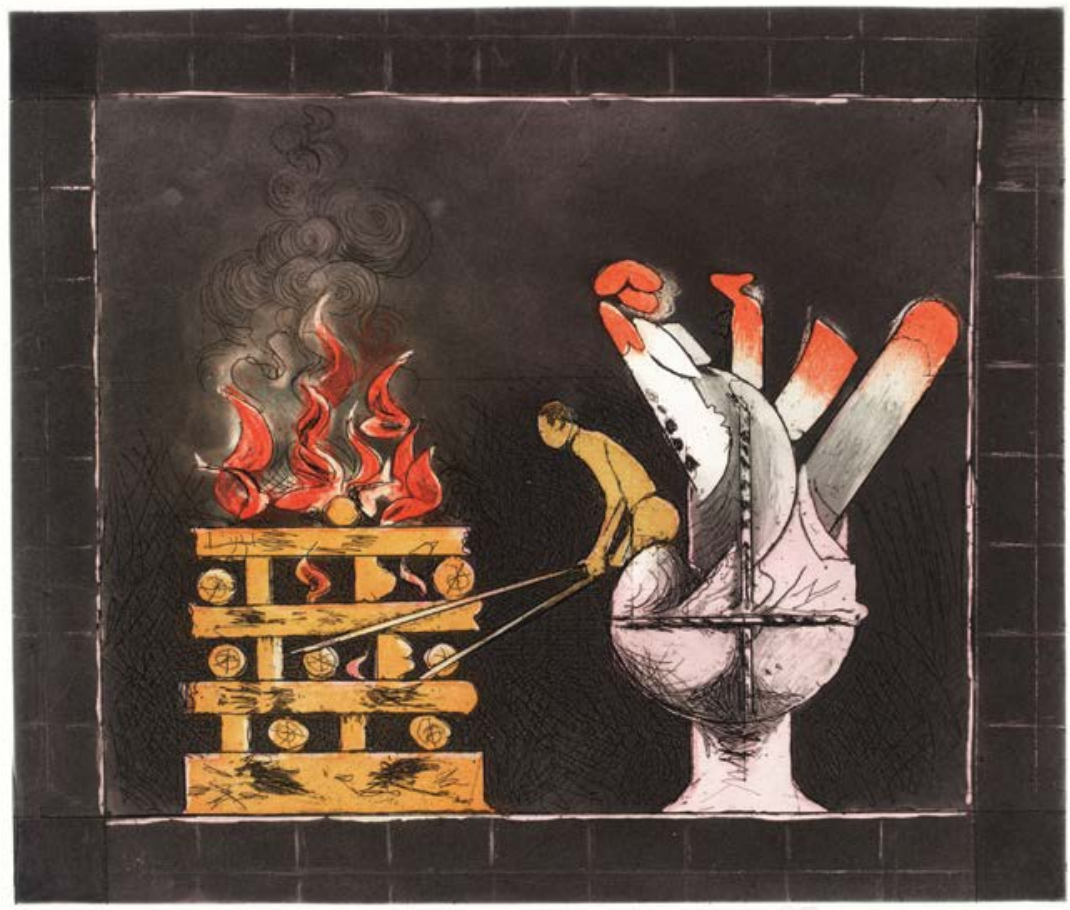

Illustration 20 Graham Sutherland, OM, from The Bestiary or the Procession of Orpheus, 17. 'The Pyre', 1978-9. (C) Estate of Graham Sutherland. Photo (C) Tate 


\title{
Graham Sutherland - The Bestiary or the Procession of Orpheus: An introduction
}

\author{
Dawn Ades
}

The Bestiary or the Procession of Orpheus was Graham Sutherland's last major work. The prints he made to accompany Apollinaire's poems of the same title, published in 1911 and originally illustrated by Raoul Dufy, were exhibited at Marlborough Fine Art in London in 1979, the year before Sutherland died. Not all Apollinaire's poems were included, and Sutherland added an extra image unrelated to the text. In the exhibition catalogue, Sutherland described his initial discomfort at being asked to make drawings for what was to be a bilingual Italian/French edition:

I don't always feel really at home making illustrations, tending to feel that I am a prisoner of the text. Moreover I have to admit that at the time I knew very little about Apollinaire, except as an activator during the revolutionary years of literature and painting in Paris. But I read the poems and very especially the notes, and in the summer of 1978 decided to have a try and produced a few gouaches ... the more I thought of the poems, the more I felt that the work might be within my capacity after all - and who in truth could resist such a line as 'among the heavenly hierarchies ... we can see beings of unknown shape and surprising beauty'? ${ }^{1}$

The most fabulous of the creatures in Sutherland's 1978 Bestiary is the final one, the ox, also the last in Apollinaire's Bestiaire. Of 'Le Bøuf', Apollinaire wrote, 'Ce chérubin dit la louange / Du paradis ...' / 'This cherub speaks in praise/Of Heaven ...'2 The cherubim, one of the 
heavenly hierarchy of angels, were identified, as Apollinaire writes in the notes, as a winged bull, but were 'in no way monstrous'. ${ }^{3}$ In Sutherland's print, the winged ox or bull, horned head haloed by the moon, seems to hurtle down or spin in a dark cloud towards a green wood. Out of the black clouds and swarming around the cherubim are monstrous forms of unknown shape. At the bottom, a small doorway opens onto bright green light; on our side of the opening, two smaller creatures hover: the winged ox, again upside down, and a donkey - the ox and ass, perhaps, of the Bible, who witnessed the birth of Christ. A winged ox is the symbol of the evangelist St Luke, too, which had figured in Sutherland's designs for the tapestry for Coventry Cathedral, Christ in Glory, of 1962. As well as the multiple biblical associations, though, this scene in Sutherland's Bestiary echoes with references to Dante's Inferno. In canto IV, Dante sees the great spirits who, through no fault of their own, were not baptised and thus cannot go to heaven. Limbo is a green meadow, an open area full of light, and Dante sees on the 'enamelled green' the shades of philosophers, scientists, heroes and poets of the ancient world, including Orpheus.

Orpheus, Apollinaire tells us in his notes, was not only the first musician, with his tortoiseshell lyre, a poet and singer, the inventor of all the sciences and all the arts, but also a magician and prophet who predicted the coming of Christ. References to Christianity as well as classical and medieval myth and legend are scattered through Apollinaire's Bestiaire, and the final poem ends with a cheery if ironic nod to a future life:

\section{Ce chérubin dit la louange}

Du Paradis, où, près des anges,

Nous revivrons, mes chers amis,

Quand le bon dieu l'aura permis.

This cherub speaks in praise

Of Heaven, and there, with the angels

My friends, we will live again,

When the good lord allows.

While the cherubim in Apollinaire's poem may sing of paradise, it is a gateway to a green light that Sutherland shows, the limbo outside both heaven and the lightless depths of hell, where Orpheus would wait forever. Sutherland engages visually in subtle ways with the tensions between Christianity and the classical myths; the powerful effect of 
Sutherland's print lies partly in the contrasts between the tiny emeraldgreen opening onto a beyond and the dark wood, the golden light around the cherub's head, and the disturbing phallic and bulging shapes of the monsters. There is promise, but perhaps only of limbo, and there are threats. Tension was a crucial aspect of Sutherland's visual approach. Of his thorn pictures and the early Northamptonshire Crucifixion, he wrote: 'One reacts to the reality of tension in a subject, physical and spiritual or psychological; and that tension paraphrased and ordered should become immediate and intensified in one's painting.'

The winged ox and cherub combined is the only mythological hybrid animal in the Bestiary. Lured as he was by the promise of unknown beings 'of surprising beauty', Sutherland's beasts in this bestiary are nonetheless mostly close to nature, although exactly what this means with respect to traditions of representation is not straightforward in the history of Sutherland's engagement with animals. The 1978 Bestiary was the third of Sutherland's bestiaries, following on from The Bees (1976-7) ${ }^{5}$ and A Bestiary (1968). ${ }^{6}$ The latter set of 26 colour lithographs includes not only carefully observed birds and animals, such as a ram, a toad and an owl, but creatures in the process of transformation, such as 'Emerging Insect', and a curious image entitled 'Insect (Simulating Seeds)', in which it is not clear whether the simulation is in nature or pictorial; perhaps the point is that it is both.

Animals had long fascinated Sutherland, and his treatment of them is integral to his investigation of pictorial form and of forms in nature. Animals could emerge, for example, from the suggestive morphologies of tree roots and trunks, which Sutherland might develop or leave as ambiguous shapes. When I was searching for earlier images of animals, time and again I thought I glimpsed one - a bird, perhaps, or a hippopotamus, or something more mythological and hybrid - only to find on checking the title that the thing was almost always vegetable rather than animal: Fallen Tree against Sunset (1940) or Green Tree Form: Interior of Woods (1940), for example. The tree trunk had momentarily suggested a corresponding but different association: animate, with legs and a snout. The hard ridges of tree bark can easily become the bristly hide of a boar or a rhinoceros. Looking first and reading the title afterwards turned out to be a way into a key and enduring aspect of Sutherland's highly individual way of perceiving and recognising forms.

Sutherland's openness to the chance encounter, to a poetry of visual analogies often inspired by a found object, is one of the aspects of his work that connects to surrealism. The link was noticed by the organisers of the 1936 International Surrealist Exhibition in London, who were 
scouting for exhibitors, and Sutherland was invited by Roland Penrose to contribute. The two oil paintings he sent, Thunder Sounding and Mobile Mask, were not the expected landscapes and were described by Alley as 'in essence jeux d'esprits'. Sutherland was not attracted to the movement as such; he was in a sense a solitary artist, and his intransigence and aims differed from those of the surrealists:

The one field in which the surrealists helped me to widen my range was in their propagation of the idea that there was worthy subject matter for painting in objects the painter would never have looked at before ... Surrealism helped me to realise that forms which interested me existed already in nature, and were waiting for me to find them.?

The parallels with surrealism, nonetheless, are more frequent than Sutherland acknowledged. As well as the morphological metamorphoses and interest in found objects, he was committed to making visible and present the unknown. 'The unknown is just as real as the known, \& it must be made to look so. I want to give the look of things to my emotionally modified forms. ${ }^{\prime 8}$ The idea that reality is much broader than what is materially present to the eye was fundamental for the surrealists. The difference is that Sutherland pursued this in the interests of his art, of the pictorial, while for the surrealists the imagination was mobilised in the interests of the real for its own sake.

In Green Tree Form: Interior of Woods, a fallen tree thrusts outwards towards the spectator, its forked branches giving it the appearance of a monstrous undefined animal, while light falls on the near trunk, emphasising the double meaning of the word. The overall shape reappears in one of the plates in Sutherland's 1968 Bestiary, although now more clearly defined as something resembling both a hippopotamus and a rhinoceros, as Chained Beast, picking up the theme of the painting The Captive, of 1963-4. This chained beast had an over-determined origin: Goya's prisoners from Disasters of War, panels of lions in high relief on the façade of the Ospedale di San Marco, and a shape in the side of a lane in Kent which reminded Sutherland of a rhinoceros. Another early painting, however, Toad (1958), is a minutely observed realistic image: a fat-bellied toad slithering along outside a sewer grating. This points to a concern with observing the essential characteristics of animals: 'only through this demonstration of their nature do animals pay unconscious tribute to the power which created them'. ${ }^{9}$ Although the manner of representing the chosen animals and birds in the later 
Bestiary is on the whole quite straightforwardly naturalistic, the imagery as a whole, the setting and scale of the creatures, is not. For example, The Elephant with its hoary skin and tusks is set in a collage-like set of scenes, with at the bottom a close-up of an open - grinning or screaming - mouth, which references the famous motif in Francis Bacon's paintings. The human creatures - Orpheus himself and the sirens - are the most abstracted, recalling Sutherland's long explorations of correspondences between mechanical and organic forms. Sutherland delights in the interrelationships between the more abstract aspects of the composition and the rich associations of the animals, which reveal themselves slowly. The formats of the prints are not only extremely varied but look to traditional pictorial structures in such a way as to invite speculation about their link to the subject. The image of The Grasshopper, for example, could be the first letter of an illuminated manuscript of the late twelfth or early thirteenth century. The strong black lines structuring the image look calligraphic and echo the curious sign-like character of the grasshopper in profile. The image harks back to Cigale 1 (1948), the first of Sutherland's oil paintings of animals which shares the heraldic fixity of the later print. This was painted in the south of France, where the sound of cicada is ubiquitous.

Many of the images in The Bestiary, such as the grasshopper and the lion, have internal painted frames, again resembling the illustrations

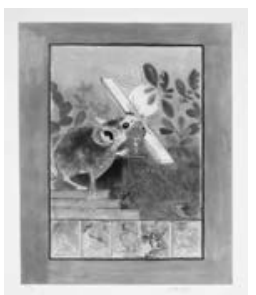
of the beasts in a medieval bestiary. The Mouse, a delightfully delicate and virtually monochrome aquatint, is distinct in that way from the others. There are five sub-panels beneath the main picture, resembling the predella panels of an altarpiece. These were often painted in grisaille, by contrast with the main image. The mouse is eating a wooden beam, whose perspectival slant faintly recalls a crucifixion but is effectively more like a floorboard. In the predella panels, the mouse is gnawing at the foundations, so their pictorial position 'underneath' is taken literally. Overall there is a light brownish wash, while the wood itself is white like the moon.

Several of the prints have a blank space beneath the main image, in the same place and similar in format to the predella panels in The Mouse, which recalls the space left at the bottom of devotional images for a text or inscription, which would give thanks to the Virgin, or Christ, or a saint, for the miracle recorded in the image (illustration 12). These were popular in Catholic Europe and also in Latin America. Sutherland could not have known the use Frida Kahlo made of these retablos, in one case 
(My Birth, 1932) leaving the cartouche blank because there had been no miracle. There may be a technical reason for the blank bands, but they are so noticeable, especially in The Flea and The Serpent (where it is coloured bright green), that an association with retablos (if not Kahlo) is possible.

The image of the flea, outsize, comfortably in bed, shoes and bedpan underneath, rubbing its feelers after a good dinner, the background a striking overall red the colour of blood and with carefully drawn holes pierced into the red flesh, is the most anthropomorphic of Sutherland's beasts. This echoes Apollinaire's text where the fleas, which feast on man, are most closely related to human beings, being partly composed of them:

Puces, amis, amantes même,

Qu'ils sont cruels ceux qui nous aiment!

Tout notre sang coule pour eux.

Les bien-aimés sont malheureux.

Fleas: our friends, even our lovers;

How cruel they are, those that love us!

We lose all our blood only to them.

For ill-fated are the well-beloved.

The anthropomorphism and exaggerated scale, however, also recall children's books and book illustrations - it could easily be the beginning of a tale of a flea - an irony Sutherland seems to relish.

Affect in the prints is as various as the formats, and often ambiguous. Apollinaire's references to Greek mythology were described as being

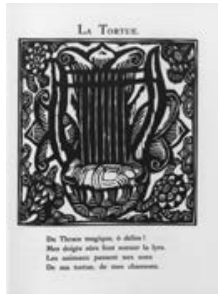
'tied in with a delicious (sometimes malicious) sense of humour, using animals as a vehicle for commenting on humans ${ }^{10}$ There is a certain cruelty, which may in fact be the consequence of an identification with the creature. In The Tortoise, appropriately the first animal image in both Apollinaire and Sutherland (illustrations 2 and 10), whose shell is Orpheus's lyre:

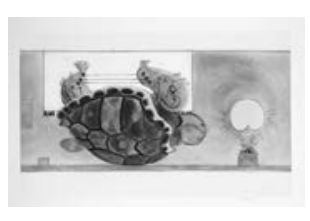

Du Thrace magique, o délire!

Mes doigts sûrs font sonner la lyre.

The sure touch of my fingers, what delight, Sounds the magical Thracian's lyre. 
The strings of the lyre are drilled through the tortoise's head and legs. Sutherland is reminding us that the tortoise shell was once part of a living body. The tortoise, which still roams wild in places like Georgia, Armenia and Greece, seems, in spite of its magnificent, hard and beautifully patterned shell, to be one of the most vulnerable of creatures. It is the source of music and song at a cost.

In the medieval bestiaries, such as MS Bodley 764, creatures we would view as mythical or fantastic, such as satyrs, the phoenix or the unicorn, are treated as no less part of the animal kingdom in nature as the horse or the wolf. That the only mythological beast in the Bestiary, the winged ox or cherub, is the last of the animals, as it is in Apollinaire's Bestiaire, may have prompted Sutherland to add a final image, unrelated to the original. Sutherland's cherubim is a kind of hinge to a world view, or its absence. The taxonomies of classical literature and their successors the medieval bestiaries were ordered according to a predominant world view and its hierarchy. The apparently haphazard sequence of Sutherland's Bestiary is challenged by the last two images, of the winged ox and the pyre. This final picture is a sinister scene, presumably a funeral pyre, the fire being tended by a small figure with long tongs who is seated on an ambiguous form resembling an almighty hand with blood-red fingertips. 'I have added one or two images that have no direct reference to the poems, but which refer, perhaps, to the difficulties of life and living', Sutherland wrote. Solace in a pantheistic belief in nature, whose complexity and variety exceed human understanding, sharply confronted by the mysteries and difficulties of life, by living and what if anything lies beyond.

\section{Notes}

1 Sutherland 1979. Referred to in this book as The Bestiary or the Procession of Orpheus, as the work is listed at the Tate, or Bestiary.

2 Translations from the French provided by Timothy Mathews.

Apollinaire 1965, 35.

4 Letter to Curt Valentin, 24 January 1946, printed in catalogue of Sutherland's one-man exhibition at the Buchholz Gallery, New York, February-March 1946.

Sutherland 1977.

Sutherland 1968.

From a conversation with Andrew Causey, 1966, quoted in Alley 1982, 77.

John Hayes, The Art of Graham Sutherland (London: Phaidon, 1980), 19.

Hayes 1980, 142.

10 Alley 1982, 168. 


\section{Bibliography}

Alley, R. 1982. Graham Sutherland. London: The Tate Gallery.

Apollinaire, G. 1965. CEuvres poétiques complètes, preface by André Billy, edited by Marcel Adéma and Michel Décaudin. Bibliothèque de la Pléiade. Paris: Gallimard.

Buchholz Gallery. Catalogue of Graham Sutherland's one-man exhibition at the Buchholz Gallery, New York, February-March 1946.

Hayes, J. 1980, The Art of Graham Sutherland. London: Phaidon. 19.

Sutherland, G. 1979. Apollinaire, Le Bestiaire ou Cortège d'Orphée. London: Marlborough Fine Art Ltd. 


\title{
2
}

\section{The Voice of Light: Nature and revelation in The Bestiary or the Procession of Orpheus}

\author{
Sarah Kay
}

\author{
Admirez le pouvoir insigne \\ Et la noblesse de la ligne: \\ Elle est la voix que la lumière fit entendre \\ Et dont parle Hermès Trismégiste en son Pimandre. \\ Admire the remarkable power \\ And nobility of the line: \\ It is the voice that the light made audible, \\ That Hermes Trismegistus tells of in his Pymander.
}

The voice of light: with this assertion of luminous sonority, Le Bestiaire ou Cortège d'Orphée $e^{1}$ by Guillaume Apollinaire and Raoul Dufy begins. Literally 'the voice that the light caused to be heard' ('La voix que la lumière fit entendre') - a voice emitted by light or a voice rendered audible by light - its sound is associated first with the extraordinary 'power and nobility of the line'. It hails, that is, a kind of ecstatic union between the bold lines of Dufy's muscular woodcuts and Apollinaire's oracular verses. ${ }^{2}$ The speaker then compares the revelations this union can offer with those of the epiphany of the divine Poemander to thricegreat Hermes:

5. But after a little while, there was a darkness ... which seemed unto me to be changed into a Certain Moist Nature ... from whence proceeded a voice unutterable, and very mournful, but inarticulate, insomuch that it seemed to have come from the Light. 
6. Then from that Light, a certain Holy Word joined itself unto Nature, and out flew the pure and unmixed Fire from the moist Nature upward on high. ${ }^{3}$

This passage from Pymander, from which Apollinaire quotes part but not all in a note, ${ }^{4}$ epitomises some key preoccupations of his and Dufy's Bestiaire: nature, obscurity, light, voice, revelation. Despite the willed ordinariness, the small-scale terrestrial attachments, of some of the inhabitants of the work, and its author's own occasional deliberate descent into platitude, readers of Le Bestiaire are asked to listen for the sound in it of a mysterious radiance-voice, and of a luminous, fiery word.

In this chapter I set out to answer to that call. I try to listen for the reverberations of this voice in poetry and image, attending to its metamorphoses and receptive to its revelations, both in the Apollinaire-Dufy composition that first conjures it into being and then in its subsequent reworking as a set of aquatints with the same title by Graham Sutherland - although with uneven results, since the voice is far less present in the later work. I begin by looking at how the influence of the bestiary tradition might shape - if differently in either case - the way nature, light and voice interact in each bestiary. ${ }^{5}$

\section{Bestiaries: illuminating the 'book of nature'}

In what sense are the Apollinaire-Dufy and Sutherland Bestiaires 'bestiaries'? ${ }^{6}$ In English, 'bestiary' is the name given to a group of medieval texts that derive from the late antique Physiologus, a work of moralised natural history of which various versions circulated; it was probably composed in Greek in Alexandria in about the second century CE, and was thus roughly contemporary with the Pymander. Literally meaning 'the naturalist', the name Physiologus probably also means 'allegorist'.? A prose work that early on acquired an associated iconography - a development that led to the word 'bestiary' also being used to designate an individual illustrated book in this textual tradition - the Physiologus was translated into neighbouring languages, giving rise to African and Middle Eastern bestiaries, and into Latin, thereby producing Western European ones.

All these works are compilations of entries, or short chapters, on various aspects of the natural world - land animals, birds, fish, trees and stones; in the principal Latin versions, there are usually between 30 and 
50 of these entries. Each is made up of snippets of Mediterranean natural lore such as are found in Aristotle's writings on animals or Pliny's Natural History, often accompanied by quotations from passages of the Bible in which the entity features. ${ }^{8}$ This 'nature', as the first part of each entry is known, is followed by one or more interpretation(s) offering a Christian or moral reading of the lore concerned (the 'allegory'). The double structure of nature plus allegory is a means of making nature reveal its truth according to a Christian conception of the word. These allegorical elaborations often, indeed, take their direction from the initial biblical quotation, and commonly cite additional passages of scripture to flesh out their meaning.

The resulting works are both bookish and syncretic: a not always easy conflation of the 'book of scripture' with a generally pagan 'book of nature'. As such, versions of Physiologus, although widely read, were neither always approved of by the Church nor readily assimilated into more 'scientific' writings unless first shorn of their allegories. In modern usage, the word 'bestiary' can be used more loosely to refer to assemblages of animal representations of various kinds, but the premodern genre of moralised natural history inaugurated by Physiologus remains an essential reference point.

In French, by contrast, the word bestiaire does not have the same primary association as the English 'bestiary' with texts, still less with the Physiologus tradition, manifestations of which are usually referred to in French as forms of le Physiologue. Rather, bestiaire is typically used to refer to any collection of animal images with symbolic meaning, in any medium, although often visual (painting or sculpture); however, it sometimes takes on a more precise textual meaning, thanks to its use in the title of medieval vernacular works composed in the wake of the Physiologus, such as Le Bestiaire de Philippe de Thaon; and also to the fact that it can refer to notable Latin bestiary manuscripts, like the Aberdeen Bestiary (le Bestiaire d'Aberdeen).

Apollinaire and Dufy seem to me to have used the word bestiaire in their title to evoke medieval bestiaries such as the Aberdeen Bestiary or Le Bestiaire de Philippe de Thaon, rather than in the looser and more general sense, even though the latter is the more common one in French. Apollinaire's poetry is frequently indebted in one way or another to medieval models, and this is true, too, I think, of his idea of what a bestiary is. ${ }^{10}$ His and Dufy's Bestiaire ou Cortège d'Orphée adapts the 'book of nature' in such a way as to make the 'nature' of each creature yield its 'allegory', or speak its truth, even if in a different way from that proposed by Physiologus - or by Hermes Trismegistus, for that matter. 
Paradoxically, although in English the term 'bestiary' refers more frequently than its French equivalent to the medieval textual tradition, Sutherland seems to have chosen the title of his work primarily as a homage to the Apollinaire-Dufy composition, since the textual reference in his images is at best implicit, and overwhelmingly to his French model. Take that reference away, and Sutherland's work looks much more like a compilation of animal images that invite a symbolic reading of some kind, in a way highly redolent of the French sense of 'bestiaire', only with much less overt connection to Judeo-Christian belief. The relation of Sutherland's bestiary to the word, and thus to the voice, is much less apparent. The nature it depicts has more obscurity and silence, more flickering fire and dance, than voice of light.

\section{Orpheus}

Of course the Apollinaire-Dufy decision to yoke the 'bestiary' to the 'procession of Orpheus' (cortège could also be translated as 'train') marks a swerve away from Physiologus towards a quite different textual tradition. The French artists thereby introduce a new strand of syncretism, a new layer in the cross-cultural patchwork, in which the moralised bestiary and the myth of the pagan singer-poet Orpheus combine. ApollinaireDufy's subjects are not only the 'beasts' in an allegorised book of natural lore (like Physiologus), they also make up the train of creatures that follow Orpheus, enraptured and transformed by his song (as in Book XI of Ovid's Metamorphoses, for example). The French work knowingly plays on the cultural gap - one in which, in the course of the work, the contradiction passes over into convergence - between the Orphic and moralising modes.

The introduction of Orpheus reinvigorates the pagan dimension of the bestiary, previously limited to its (to modern eyes) folkloric zoology. Orpheus also endows this zoology with new vitality. He makes it possible to see the creatures in the Apollinaire-Dufy work as being in movement - as processing - and as potential metamorphoses of other creatures, perhaps even of one another. He thereby imbues them with a mobility and contingency lacking from the more quiescent ontology of Physiologus.

More significantly for my purposes, the presence of Orpheus foregrounds the category of voice. That the Apollinaire-Dufy Bestiaire is vocalised, or sounded, is not unprecedented since the genre, as I have said, is organised around the idea of making nature speak its truth. 
Orpheus, however, gives this sounding an actual voice and complicates its revelations by giving it poetic and musical, mythic, even erotic and quasi-magical powers, alongside the biblical authority of the bestiary.

Orpheus's voice is best known for its capacity to transform those who hear it, but in the Apollinaire-Dufy work it becomes an agent of many kinds of change. The most blatant transformations effected by its sounding are those undergone by Orpheus himself and by the voice of the poet. I shall also argue, however, that the capacity to reveal or name passes from Orpheus to the poet of the Apollinaire-Dufy bestiary and on to the creatures within it. As voices sound through the work, we gradually apprehend more fully, alongside its cultivated triviality and humour, indeed as integral to these qualities, the potentially revelatory power of the voice - although its revelations are not necessarily always what we welcome or expect. Out of nature, voice illumines and light speaks or sings, as the Bestiaire's initial quatrain asserts; but in its final one, it appears that it may only do so fully when we are no longer there to hear it.

The transformations of Orpheus are treated very differently by Sutherland. The mythic figure mutates through his images too, but towards increasingly mechanical (as opposed to human) formations. Initially a single, tight-lipped human face, Orpheus becomes a group of wriggling, metamorphic human-machines perceived from a distance, and finally a vast, complex figure in which organic and inorganic forms combine, and by which human bodies are dwarfed. ${ }^{11}$ Less a personified force within nature, as he remains through Apollinaire and Dufy, Orpheus's relation to the voice in Sutherland's bestiary is correspondingly obscured; he seems to move in response to music more than he produces song.

\section{Organisation and 'the book of beasts'}

Scholarship on late antique and medieval bestiaries distinguishes the various texts, or bestiary versions, that make up the genre by cataloguing the different entries and their order in each one. ${ }^{12}$ It is instructive to do the same with the Apollinaire-Dufy Bestiaire, which in its published form contains 26 short poems, each representing a different creature, which are divided into four groups by the four additional poems about Orpheus. ${ }^{13}$ This organisation both recalls and differs from those of the many texts that make up what I call the Western Latin bestiary tradition, among which the bestiaries in Latin and the medieval European vernaculars fall. Texts of this kind gradually move away from the broad 
view of natural history found in Physiologus. The original Greek entries on stones and trees are almost all jettisoned, with the result that, since there were never many on fish, bestiaries come to contain almost only what we might think of as animals: mammals, birds and reptiles. It is in this sense that they are no longer 'books of nature' but 'books of beasts', libri bestiarum. And whereas Physiologus has no discernible zoological structure, but presents its entries in a seemingly random order, medieval bestiaries tend to adopt one. At the simplest, they sort entries into a beast and a bird section; in the most complex cases, they recognise as distinct categories wild beasts, domestic animals, tiny creatures, serpents, birds, fishes, and so forth, and group their entries accordingly. ${ }^{14}$ The so-called 'second-family Latin bestiary', to which most of the well-known exemplars belong, follows this structure, being divided into sections of uneven length, sometimes marking the beginning of a new one by a full-page image of the most spectacular or regal beast in its category. ${ }^{15}$

The Apollinaire-Dufy Bestiaire follows a similar organisation, since the four parts into which its entries are distributed also vary in length and are defined by zoological category; each one is headed by Orpheus, who takes the place of the enlarged section-initial entry. The choice of entries in the French work also bears comparison with that found in the second family. Table 1 maps this structure, indicating in bold typeface the creatures which Le Bestiaire has in common with the Latin text:

Table 1 Organisation of the Apollinaire-Dufy Le Bestiaire ou Cortège d'Orphée

\begin{tabular}{|l|l|l|l|}
\hline Beasts & $\begin{array}{l}\text { Tiny creatures, } \\
\text { insects }\end{array}$ & $\begin{array}{l}\text { Fishes, water } \\
\text { creatures }\end{array}$ & Birds \\
\hline Orpheus & Orpheus & Orpheus & Orpheus \\
\hline tortoise & caterpillar & dolphin & sirens \\
\hline horse & fly & octopus & dove \\
\hline Tibetan goat & flea & jellyfish & peacock \\
\hline serpent & grasshopper & crayfish & owl \\
\hline cat & & carp & ibis \\
\hline lion & & & ox \\
\hline hare & & & \\
\hline rabbit & & & \\
\hline dromedary & & & \\
\hline mouse & & & \\
\hline elephant & & & \\
\hline
\end{tabular}


It is striking that most of the Apollinaire-Dufy beasts (those in the first column) and all of the creatures classed as birds (final column) are also present in this particular Latin bestiary, whereas there is almost no overlap in the sections on insects and fish. Even the fact that the French artists count the ox among the birds is less weird than one might think, since in pre-modern bestiaries creatures sometimes migrate across species; the ostrich, for example, is alternately a beast or a bird, while sirens variously appear as beasts, birds or fish. This comparison of the organisation of the Apollinaire-Dufy Bestiaire ou Cortège d'Orphée with medieval exemplars shows not only their acknowledgement of this tradition but a possible familiarity with these large and spectacular second-family books.

Although reusing much of the same material as the French work, Sutherland in his Bestiary or the Procession of Orpheus attests to a much looser sense of 'bestiary'. The contents of this work can be tabulated as in Table 2:

Table 2 Organisation of the Sutherland Bestiary or the Procession of Orpheus

\begin{tabular}{|l|l|l|}
\hline Beasts & $\begin{array}{l}\text { Tiny creatures, } \\
\text { insects }\end{array}$ & ??? \\
\hline frontispiece & Orpheus & Orpheus \\
\hline Orpheus & caterpillar & octopus \\
\hline tortoise & fly & sirens \\
\hline lion & flea & ibis \\
\hline snake & grasshopper & ox \\
\hline mouse & & pyre \\
\hline elephant & & \\
\hline
\end{tabular}

Reducing the entries on Orpheus results in cutting back the number of sections from four to three. The first two are recognisably the same as in the French model, but only one of the Apollinaire-Dufy sea creatures has been preserved, and if two of their 'birds' have been retained (sirens, ibis), the ibis is the only one that Sutherland depicts as bird-like. If the first section, though shorter than the French equivalent, remains recognisably one of 'beasts' that shows correspondence with the high medieval bestiary, the same is not true of the second, and I cannot see any zoological coherence at all in the final section. There seems rather to be a cosmological one, with the entries between them representing the four elements of water, air, earth and fire, as if marking 
a return to the passage from the Pymander 2.6 to which Apollinaire refers, where the four elements are enumerated. ${ }^{16}$

It would be surprising if Sutherland were not familiar with the same medieval bestiaries as Apollinaire and Dufy seem to have been, since the best-known and most magnificent examples of second-family texts were made, and are still located, in Britain. Rather than veering away from, but then wheeling back to, medieval antecedents as the French work does, Sutherland seems deliberately and increasingly to disrupt all reference to them, distancing himself from nature towards both the mechanical and the mystical.

\section{Legibility and illegibility of the animal}

The alliance of the 'book of nature' with 'the book of scripture' suggests an impetus to articulate nature via the word, and in that sense to render it legible, to treat it as if it really is a book. An important feature of the organisation of medieval bestiaries, and of both these modern ones, is the space of the page that serves as a frame and reference point for its contents. Both Dufy and Sutherland draw frames around their images that parallel and confirm the confines of each page; these are not always present in Sutherland, but when they are, they are unusually insistent and ornate.

The dimensions of the page affect the way readers apprehend the entries the pages contain. Both within and between the sections of the Apollinaire-Dufy Bestiaire there are startling juxtapositions of scale (mouse - elephant - caterpillar; flea - dolphin - octopus), of degrees of familiarity (Tibetan goat - rabbit), and of the seemingly real with the seemingly mythical (owl - siren). Similarly disconcerting sequences, if somewhat differently articulated, are found among Sutherland's images. These jarring differences between juxtaposed subjects are both emphasised and masked by their integration with the rhythm of the page: whatever their size or status, flea or elephant, dolphin or dove, each has a page to itself. In the Apollinaire-Dufy work, as in any ordinary book, these pages have identical dimensions throughout the volume; the same space is more or less uniformly disposed between an image (at the top) and verses (underneath). Although there is variation in the size of the drawings in Sutherland's Bestiary, their compilation into a loose-bound portfolio equally has the effect of paginating them. This presentation, which in the case of a bound volume means that one never sees more than two full pages at once, subordinates the work as an ideal 
entity to the material properties of its support, and promotes the page as a representational space that has no pretensions to match that of life. Each of the two - the representation and the part of nature that it represents - is, as it were, free to tug against the other.

Confronted with a rhythmed succession of inscribed surfaces, readers of both these twentieth-century bestiaries, like those of their medieval equivalents, are invited to read each creature as page. Conversely - since the creatures are represented as bearing implications for human experience, love and religion - readers are also called upon to make comparisons between ourselves and them, as fellow members of the same natural world. Sometimes the poems use a hortatory mode similar to the sermon style of the medieval bestiary (as when readers are told not to be lascivious and cowardly like the hare, but as creatively fecund as it). ${ }^{17}$ Sometimes the summons is framed as a wish (as, for instance, to have one's days ill spent, as if gnawed by a mouse). ${ }^{18}$ Some entries rely on explicit comparison (similarly to the dove, the poet loves a Mary), or on a traditional symbol (Orpheus asserts that fish represent Christ the Saviour), or on an assumed similitude (as when the poet suggest readers might emulate the poetic toiling of various insects). ${ }^{19}$ Such likenesses between human readers and the nonhuman animal on each page are constructed in different ways in different entries: more in the mode of continuity in the case of the cat, which is another desirable member of the poet's household alongside an intelligent woman, books and friends; or more in that of analogy, as in the entry immediately following, in which the caged lion is like a fallen king. ${ }^{20}$ Creatures thus are presented both 'as themselves' and 'for us', a duality or double-dealing infuriating to the more purist among animal studies critics, but one that I think follows inevitably from the perplexing relationships of overlap and difference that crisscross between humans and other animals. Apollinaire's verse readings of his chosen creatures can seem gauche or flippant, but they might be better seen as resulting from humorous collusion with the long-standing demand to read both what is legible and what remains illegible in other animals.

Indeed, if bestiaries have often involved collaboration between writers and visual artists, it is because the animals already have something of the quality of undecipherable pictograms - perhaps literally so in the Egypt of the original Physiologus, where hieroglyphs were still in use. This is the more true of a bestiary like Sutherland's, whose images are more complex and more enigmatic than Dufy's, and that furthermore lack any supporting text other than an identifying title. The converse - text without image - seems never to have been envisaged, 
since Apollinaire's own manuscript drafts show him doodling ideas for entries that will subsequently appear in his Bestiaire, and that include drawings from before his collaboration with Dufy. The folio of which the verso is given as illustration 21 is written on bank letterhead and contains lines relating to poems on the ibis, owl and lion, together with drawings of a tick (?), fly and caterpillars. ${ }^{21}$

The resistance to legibility of the natural world is reflected in the fact that traditionally bestiary images have tended to promote enigma

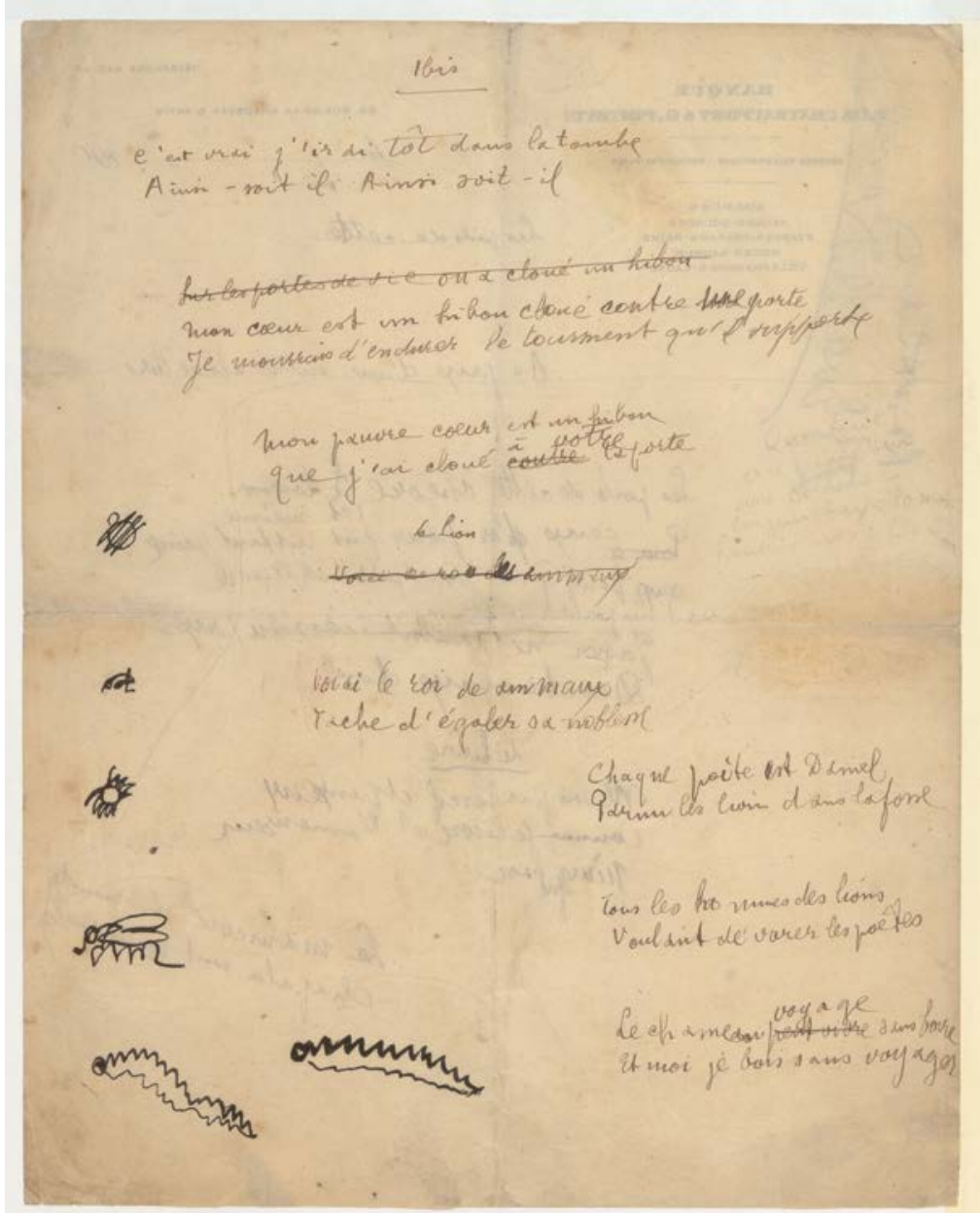

Illustration 21 Guillaume Apollinaire, manuscript draft for Le Bestiaire. (C) Bibliothèque nationale de France, n.a.fr. 25609, fo. 7v. Reproduced with permission 
over illustration in any explanatory sense of the term. Medieval depictions of creatures such as the hydrus and crocodile or the hyena are thoroughly enigmatic, and this dimension is carried through in Dufy's woodcuts. One may be puzzled, for example, by the tortoise as lyre, which enables Apollinaire's poetic persona to appropriate the Orphic voice, or the oddly mythical winged horse and cherubic winged ox, or the crayfish and carp bizarrely turned into illustrations for a recipe book or menu, or the jarringly biblical serpent. This last image is incongruous because Dufy's depiction of the temptation in Eden unambiguously references the same Judeo-Christian tradition as medieval bestiaries, whereas Apollinaire's accompanying verses enumerate female victims of serpents from a range of cultures - not just Eve, but also Eurydice, and Cleopatra too. ${ }^{22}$ Dufy's choice here seems a deliberate acknowledgment of the considerable number of finely painted medieval bestiaries - most of them from the second family, indeed - that begin with a series of texts and paintings of the opening scenes of Genesis. I shall come back to the implications for the voice of these pages, remarking here only that the effect of juxtaposing texts and images in the bestiary is less to make the images legible than to render the texts iconic. The page is a sensory - including auditory experience as much as it is one of reading, strictly speaking.

\section{The sensory space of the page}

The sensory properties of the bestiary page play a vital role in the oscillation between life and art and between legibility and its opposite, and in how readers respond to the question of how alike human and nonhuman creatures are. This was pre-eminently the case with medieval bestiaries, which were almost always copied on parchment, a refined form of animal skin that clearly bears traces of its animal origin in the form of visible pores, scars, veins, stretch marks, and so forth. Processing the skin into parchment bleaches and softens it so that it almost looks like human skin. The material surface of the page thus contributes, in its mute presence, to the difficulty of determining the relationship between human and nonhuman animals, seeming to pose the questions 'What creature's skin are we reading?' and 'How does it matter?'

Another approach to the problematic boundary between human and nonhuman animals is raised by a different aspect of the page: namely the senses it actively engages, which are shared by many forms of life. Turning the pages of a bestiary involves, in the first place, a call to looking that exposes the sense of sight to scrutiny. Additionally, because of the 
contact between the reader's skin and the skin of the page, the act of reading intensifies the sense of touch. Because sight and touch are common to human and most nonhuman animals, they play a part in the comparisons between them that the reader is invited to undertake, anchoring their relationship in overlap or communality rather than in difference. The first, limited, printing of the Apollinaire-Dufy work was bound in parchment and printed on a high-grade paper called papier Japon impérial that appeals to the senses of sight and touch. ${ }^{23}$ But it is the case for sighted readers that any act of reading can activate an interplay of sight and touch. Eye and hand travel through the volume in different movements and at different tempi, but both at the same time; my sense of touch is differently engaged when I read the ApollinaireDufy work in the Pléiade edition than when I read a thirteenth-century bestiary, but it is still engaged. Sutherland's assembly of his images in a portfolio means similarly that, in order to look at them, you also have to handle them. Sensory contact with the page is often reflected back in the representations upon it, for instance in the way sight and touch are foregrounded by particular images, like (in Apollinaire-Dufy) those of the cavorting (or contorting) elephant and the scene with Adam and Eve, or (in Sutherland) of the octopus.

Less self-evident, but more important for this essay, is the page's support for the sense of hearing as well - another sense likewise common to both human and nonhuman creatures. Pages themselves do not make much noise, but when the page is literally a skin, or made to resemble one, it evokes what is, or has been, a breathing body with a voice. The role of breath and of the voice becomes more marked with the development, from the late eleventh century, of verse bestiaries. ${ }^{24}$ Not only does the inscribing of verse on the page imply rhythm and breath, this implication seems to promote the overlap between human and nonhuman voices as an explicit theme in more entries. The reader of these works is faced with the phenomenon - common in the Middle Ages, but only returning now with the popularity of audio books - of the book as sounding voice.

As with sight and touch, then, the sense of hearing may be projected back into the page by the representations on it. This is notably the case, in pre-modern bestiaries, for the lion, one of whose traditional natures is that its cub is born apparently lifeless but revived on the third day when its father roars and breathes life into it. Voice also plays a role in the chapter on the elephant, which is tricked by hunters so that it falls, but is revived by the bellowing of its fellow elephants. ${ }^{25}$ Voice and breath are evoked by these same creatures in the Apollinaire-Dufy bestiary (and 
Sutherland's too, to a lesser extent). Apollinaire's

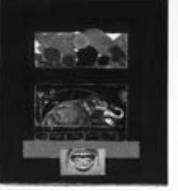
caged Lion, with verses rhyming image with cage, is accompanied by an image that seems to extend the rhyme to rage as the lion rears up in its cage, furiously roaring its indignation. Their Elephant boasts tusks that, according to the verse, place its life in jeopardy, like the singer-musician who wins glory only by giving up what is most precious in his mouth - 'melodious words' - while the elephant in the image, its tusks still in place, plunges around above. ${ }^{26}$ The Sutherland image of The Elephant is unusual in his Bestiary for explicitly evoking the human voice, in a striking dismemberment and reconfiguration of Dufy's image and Apollinaire's poem (illustration 13).

Medieval bestiaries that begin with scenes from Genesis present an orthodox Judeo-Christian version of what Poemander reveals to Hermes: the creation of the world through a profound interplay of nature, obscurity, light, voice and revelation. Darkness and chaos reign, God pronounces the word, the word brings light, and nature follows. After God has named and the world has come into being, Adam is charged with naming the animals. For some scholars, this latter scene is key to the entire bestiary genre, as though underlying the whole relation of 'nature' to 'allegory' is the more radical one of 'creature' to 'name'. ${ }^{27}$ Illustration 22 from the famous Northumberland Bestiary gives an example of this scene. Adam is represented enacting a mysterious inaugural act of translation, in which his task is to divine and render into human language the divine words spoken by God when the creatures were first created. He is helped by two mysterious female figures with scrolls that echo the scrolls of the immediately preceding creation scene and which, like it are blank (illustration 23). Such scrolls are the medieval equivalent of speech bubbles whose role is to represent the voice.

One can sympathise with Adam's difficulty in the face of the enigma of the animal. Somehow he has to divine, from the mass of creatures before him, which is divinely intended to be endowed with which name. When God made them they looked orderly enough, sorted into color-coded ranks, but now to Adam's eye they have scattered pellmell. His voice, as he somehow fulfils this impossible mission, enacts what the bestiary tradition aspires towards: recognising identity between revelation and physis; finding understanding in opacity; hearing the voice of epiphany in nature.

We are now at a point where we can listen for the avatars of that voice in Le Bestiaire ou Cortège d'Orphée and compare the Bestiaire with the work by Sutherland. 


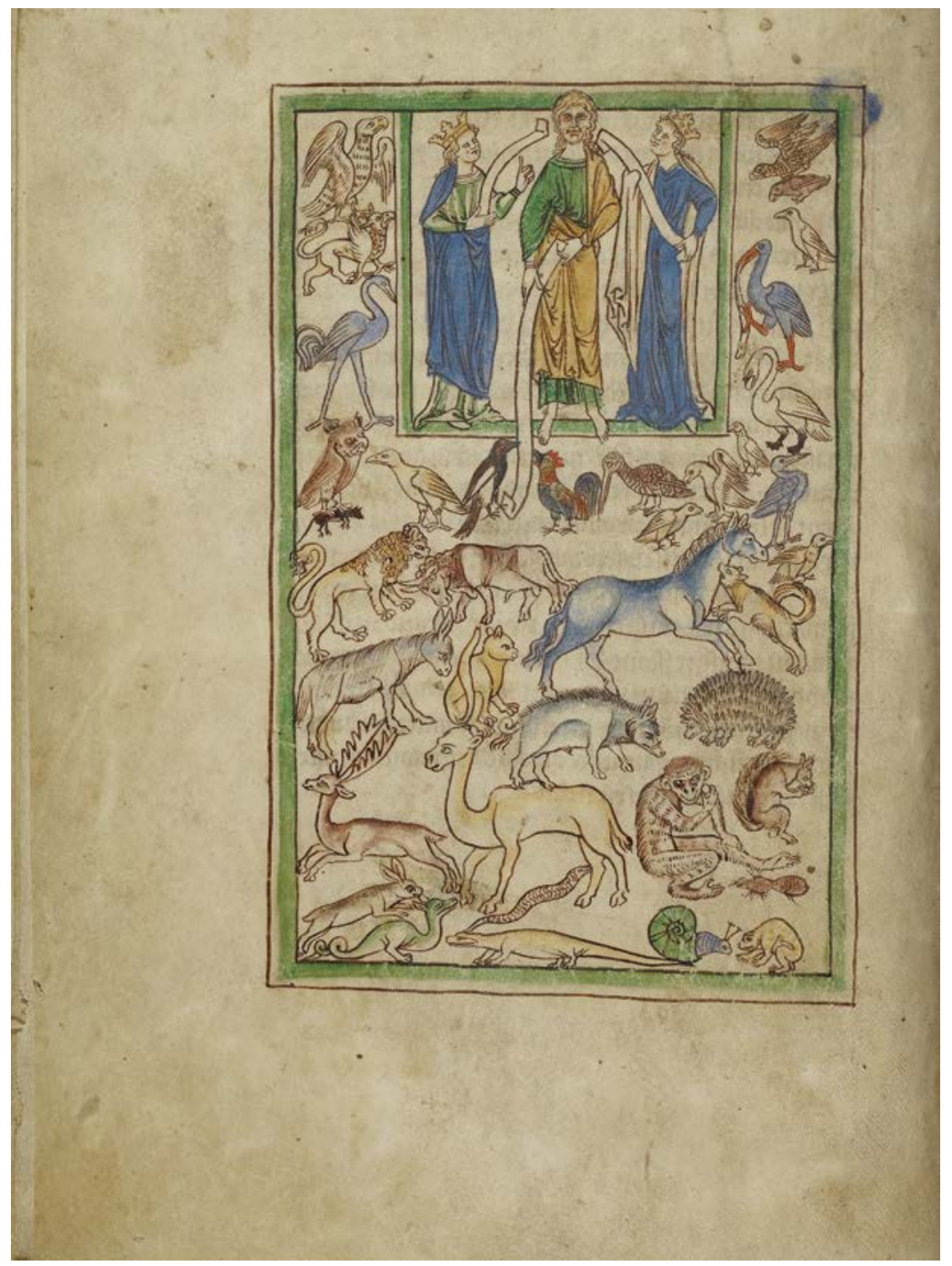

Illustration 22 J. Paul Getty Museum, Los Angeles, MS 100 (Northumberland Bestiary), fo. 5v. Adam naming the animals. Public domain. Digital image courtesy of the Getty's Open Content Program 


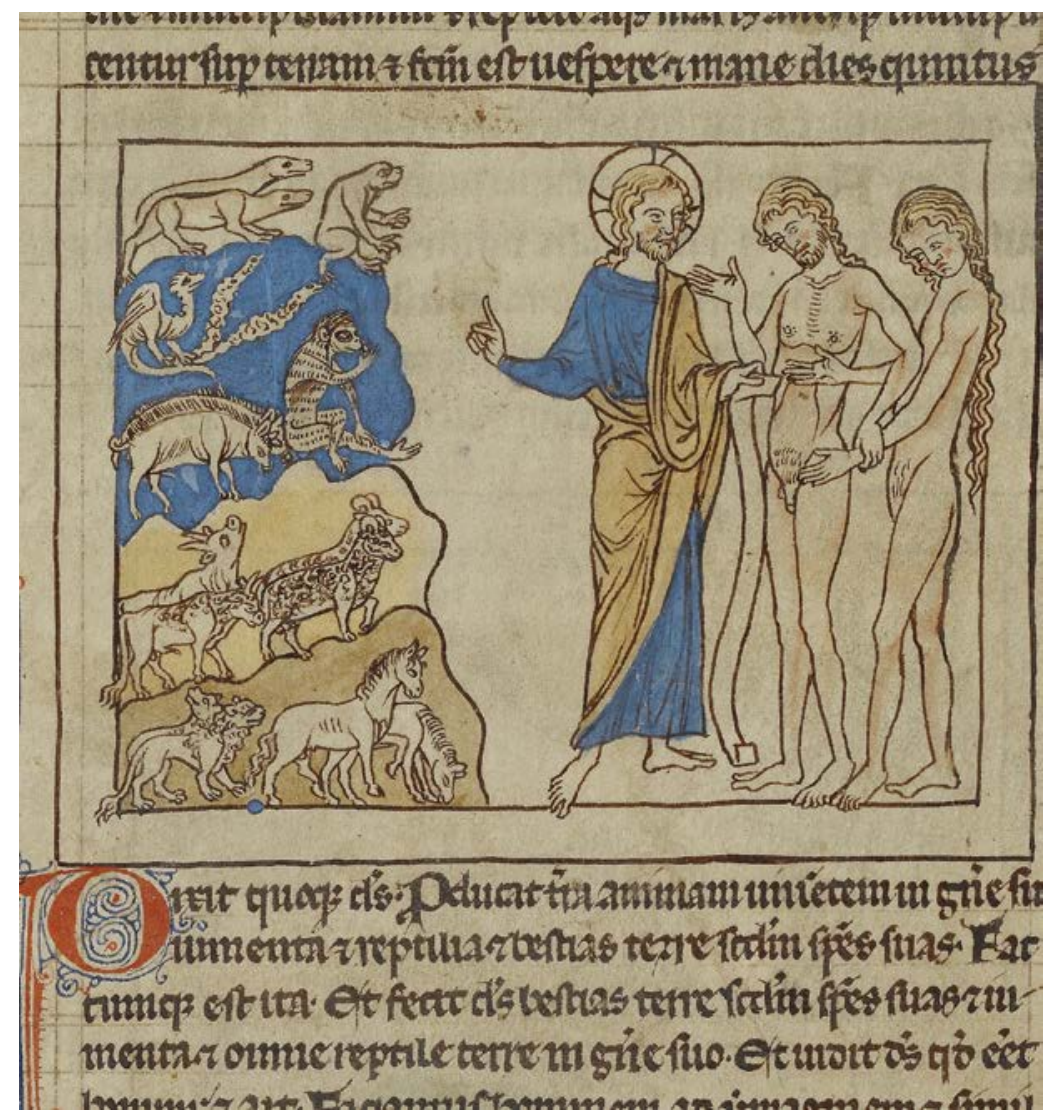

Illustration 23 J. Paul Getty Museum, Los Angeles, MS 100 (Northumberland Bestiary), fo. 3v. Creation of humans and animals. Public domain. Digital image courtesy of the Getty's Open Content Program

\section{Mutations of the voice}

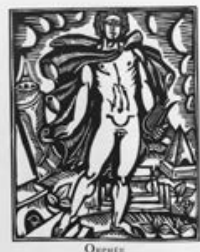

The initial Orpheus entry in the Apollinaire-Dufy Bestiaire aspires, like Adam naming the animals, somehow to translate between revelation and mute reality. In Dufy's image, Orpheus assumes godlike proportions, dominating a dwarfed landscape of miscellaneous architecture and vegetation, the winds of inspiration puffing out his tunic (illustration 1). He carries a lyre, icon of lyric effusion, which identifies 
him as a musician and singer as well as a poet. The wind in his clothes suggests not just inspiration but the breath of inspired singing. The accompanying quatrain, quoted at the beginning of this chapter, evokes the voice of light, or a voice made audible by light, as if the print on the page were somehow identical with the black-and-white technique of woodcut, and both were somehow sounded, breathed and sung. Inspired song exemplifies the sonorous manifestation of line and light.

The verses and drawings that follow continue to exploit this strength of the line, its contrast of light and dark, and its identification as sonorous voice. Different vocal registers - spoken and murmured, as well as singing - sound through the entries that follow, producing their own bizarre discrepancies of scale, like those among the creatures themselves, between conversational or off-the-cuff remarks, poetic labour, dismal lament or angelic song. Light, line, darkness, text, are all directly present throughout the Bestiaire, but the singing voice is explicitly conjured at its beginning as a means of quilting text to image and breathing revelation into nature, legibility into enigma, and mutability into both.

In the second quatrain, on The Tortoise, Apollinaire seems to adopt the voice of Orpheus as a means to appropriate - or maybe identify with - the voices of beasts. The tortoise-lyre of the magical Thracian, that is to say Orpheus, enables the delirious poet to summon up in song a procession of the animals:

\section{Du Thrace magique, ô délire!}

Mes doigts sûrs font sonner la lyre.

Les animaux passent aux sons

De ma tortue, de mes chansons.

Madness! From the lyre of the magical Thracian [i.e. Orpheus]

my sure fingers bring forth sound.

The animals process past to the sounds

of my tortoise, of my songs.

Another rather flat-footed note confirms Orpheus's association with the lyre and attributes the invention of the instrument to Mercury, who also gave one to Apollo. Like the earlier note on the Pymander, the note is as striking for what it omits - in this case the homonymy of Mercury with the Hermes of the opening poem, and of Apollo with Apollinaire as for what it contains. It does, however, assert that Orpheus foretold the birth of the saviour, thereby placing him in the same mystical 
company as Hermes or as the allegorising approach to the world in which Physiologus was composed. Sounding his own voice through the tortoise's shell, the poet joins the ranks of ecstatic singers, all divinely inspired, and some - like Apollo - divine. Dufy's image should be compared with Sutherland's, which depicts not a lyre made from a carapace, but a mutilated creature that it feels offensive to equate to an instrument of human art.

The ecstasy of song continues in the next

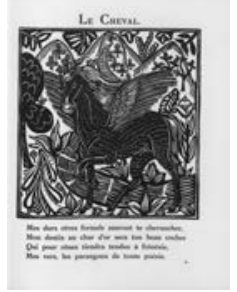
Apollinaire-Dufy entry, on the winged horse - an entry not taken up by Sutherland, who thereby again avoids engaging with the voice (illustration 3). As Pegasus, the horse is another paragon of poetry. It was a blow from Pegasus's hoof that created the fountain of the Muses, and it is this event that Dufy seems to have chosen as the subject of his woodcut. The horse appears differently in the verse: as borne up in the sky like Orpheus buoyed up by the breeze, an Apollo-like figure alternately astride it and harnessing it to his golden chariot. Careening across the heavens, this inspired horse is guided and reined in only by the formal constraints of verses pulled so taut as to induce their own kind of frenzy:

Mes durs rêves formels sauront te chevaucher.

Mon destin au char d'or sera ton beau cocher

Qui pour rênes tiendra tendus à frénésie

Mes vers parangons de toutes poésie.

My harsh, formal dreams will know how to ride you.

My fate, with its golden chariot, will be your handsome coachman, holding, as its reins pulled back to the point of frenzy, my verses, paragons of all poetry.

This voice undergoes a number of mutations through flippancy and portentousness until the beasts end with the elephant, whose ivory (or perhaps they are already piano ivories?) has the value of unsung melody. I have already mentioned Sutherland's elephant,

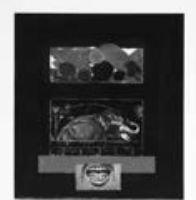
where voice is indeed evoked in a kind of painful rebus of the Apollinaire-Dufy entry (illustration 13). What sound and what emotion are we supposed to attribute to the open human mouth at the bottom of the picture? Are its lips parted in astonishment or in another version of Munch's famous silent scream? 
The Apollinaire-Dufy beast section closes with the silently melodious elephant, and so we pass on to two sections of insects and sea creatures, none of which has a voice in the strict sense, except for the dolphin, although some of the insects emit sounds. Orpheus reappears at the beginning of the first of these. Shrunk now to the measure of the landscape, and without his lyre, he asks us to look at the 'abhorrent' swarm of insects. The poet, by contrast, distances himself from Orpheus by praising the caterpillar for toiling to improve itself, and endorses the fly, whose songs were learned from Norwegian snow gods. While he finds admirable the insects that Orpheus despised, with fish it is the other way around. Orpheus, once again equipped with his lyre, and behaving exactly like an allegorising bestiarist, asks us to admire the fish as symbols of Christ. The poet, however, finds them a spur only to discouraging reflexions, perhaps because none of the fish seem capable of speaking or singing; the octopus just throws away its ink.

In the final section on birds, however, song is emphasised again, although after the separation of Orpheus from Apollinaire and the foray among non-vocal creatures, the relations of the voice to darkness and light, opacity and revelation, is now more complex and ironic than before. Orpheus, who we saw embrace the Christianising manner of Physiologus in the section on fish, introduces the one on birds with verses that moralise different values of song. He begins with the myth of Alcyone, who threw herself into the sea when told of the death by drowning of her husband, Ceyx, but was then changed - as was Ceyx - into a halcyon (kingfisher). Love, another winged figure and appropriate to Alcyone's devotion to her husband, is next on Orpheus's list. And third come sirens, which seemingly draw all the birds into the category of the 'dangerous and inhuman'. (The classification of sirens as at least part birds reflects the usage of pre-modern bestiaries.) Orpheus's overtly Christian stance here - as with the fish - confirms his conversion to the Physiologus tradition: his pagan 'nature' has been 'allegorised' into orthodox teaching. In his new frame of mind, he apocalyptically contrasts these 'accursed birds' with the angels of paradise. In Dufy's representation of him, Orpheus again has his lyre and is presumably turning his talents to angelic song. This journey taken by Orpheus from transformer of nature to promoter of Christian truth is to be contrasted with the progression he undergoes in Sutherland's Bestiary where, as I observed previously, the forms in which he is presented become less unified and less human, unconnected to song of any kind, although apparently in motion.

In Apollinaire-Dufy, by contrast, it is the poet figure who becomes more secular than Orpheus has become. His sympathies lie instead 
with the ennui of those anti-angels the sirens (illustration 6), and with the endlessly repetitive musical contrivances of the sea:

Saché-je d'où provient, Sirènes, votre ennui Quand vous vous lamentez au large, dans la nuit? Mer, je suis comme toi, plein de voix machinées Et mes vaisseaux chantants se nomment les années.

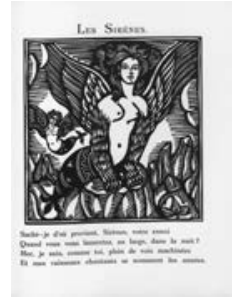

Might I know whence comes your ennui, sirens, when you lament at night far out at sea?

Sea, like you I am full of artfully contrived voices and my singing ships are called the years.

The form of this entry - four alexandrine lines arranged in rhyming couplets - is the same as that of the quatrain on The Horse. The images of the two entries, too, are alike, both dominated by a winged creature that represents a certain kind of poetic voice (compare illustrations 3 and 8). But the kinds of song that each voices are diametrically opposite: the fiery, precipitous, sky-borne ecstasy of the horse contrasts with the weary, watery, almost mechanical lamentation of the sirens. 'Watery' and 'almost mechanical' describe quite well the image Sutherland creates for the siren; but there is no sign here of any song as she reaches vainly, open-mouthed and yet with no recognisable voice, for whatever floats ahead of her.

All the other birds in this section of Le Bestiare reprise bestiary birds, but their meanings are increasingly depressing, from the

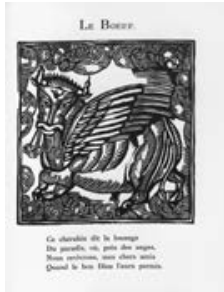
embarrassing peacock to the lacerating owl to the elegiac ibis. ${ }^{28}$ None, however, is explicitly associated with song until the surprising final one, the cherubim in the form of a winged ox (illustration 8), in which, after all these reminders of mortality, the poet optimistically looks to a cheerier time in the hereafter, surrounded by his friends and by choruses of cherubim like this.

In early bestiaries, the ox appears only among domestic livestock. But it is also known as a sign of the end of time, because it is one of the winged creatures emerging from the whirlwind in the apocalyptic vision of the Old Testament prophet Ezekiel. ${ }^{29}$ A simplified form of the same vision reappears in the Book of Revelation, where John sees, 'round about the throne ... four beasts full of eyes before and behind. And the 
first beast was like a lion, and the second beast was like a calf, and the third beast had a face as a man, and the fourth beast was like a flying eagle' (Rev. 4: 5-8). These animal-men came to be interpreted as symbols of the Evangelists, with the ox representing Saint Luke; it is this iconography that Dufy has adapted, adding streams of breath from the ox's nostrils, perhaps to represent, like the wind in Orpheus's tunic, the sound of the voice. Indeed, in transforming the winged ox into a singing cherub, Apollinaire seems to have (not altogether seriously) conflated Ezekiel's vision with Isaiah's of the winged seraphim around the throne of God that 'cried one to another, and said: Holy, holy, holy, the Lord God of hosts, all the earth is full of his glory' (Is. 6:3).

\section{Ce chérubin dit la louange}

Du paradis, où, près des anges,

Nous revivrons, mes chers amis,

Quand le bon dieu l'aura permis.

This cherubim praises paradise

where with the angels,

we will live again, my dear friends,

when God permits.

It appears that at the end of Le Bestiaire there is a genuine return to inspired song: a song that is prophetic and associated with the divine, able to sound out and to name, to sing something of the truth of nature. At the end of time - or the end of the text - nature no longer needs to be 'revealed'; it is itself revealing. But it sings in its own way, not for us but in itself, once we are done.

The way Apollinaire and Dufy shape their Bestiaire from an unorthodox 'naming of the animals' - Orpheus's voice - to an unusual representation of Apocalypse - the singing ox - confirms their familiarity with the medieval bestiary, where the same trajectory is found, and their originality in transforming it. ${ }^{30}$ One of the most striking of these changes, effected by also identifying it as a 'procession of Orpheus', is to translate visual contrasts of scale, inherent to the bookishness of the traditional bestiary, into contrasts of voice. Orpheus's transformative powers contribute to these mutations: they are discernible in Orpheus himself and in the development of the poetic voice that moves through ecstasy, insect noise and lamentation, to ultimate withdrawal. Although based in text and image, the Apollinaire-Dufy Bestiaire is held together by voice, from the prophetic voice of Orpheus at the beginning to the 
revelatory voice of the winged ox at the end. This voice is understood, at the end, as arising from nature, not about it: it shines and delineates from a point where poet and painter no longer exist. In the words of Pymander, the voice of light proposed by art in the opening stanza becomes a voice issuing from a 'moist nature ... from whence proceeded a voice unutterable, and very mournful, but inarticulate, insomuch that it seemed to have come from the Light' (Pymander, 2.5). Not so the Bestiary of Graham Sutherland, in which colour is not so much sonorous as it is mobile, licked at either end by the tongues of flame from the altar next to the tortoise or the concluding pyre. He seems closer to what Poemander goes on to say in 2.6: 'Then from that Light, a certain Holy Word joined itself unto Nature, and out flew the pure and unmixed Fire from the moist Nature upward on high.'

\section{Notes}

1 All references to the Apollinaire-Dufy Le Bestiaire ou Cortège d'Orphée are to Apollinaire, 1959, CEuvres poétiques. Translations are my own.

2 In his notes to this stanza, Apollinaire writes first, 'Il loue la ligne qui a formé les images, magnifiques ornements de ce divertissement poétique', and then 'Cette "voix de la lumière" n'est-ce pas le dessin, c'est-à-dire la ligne? Et quand la lumière s'exprime pleinement tout se colore. La peinture est proprement un langage lumineux' (Apollinaire, 1959, OEuvres poétiques, 33).

3 Read in The Divine Pymander of Hermes Mercurius Trismegistus an Egyptian Philosopher, Book 2.

4 Apollinaire's note reads: "Bientôt, lit-on dans le "Pimandre", descendirent des ténèbres... et il en sortit un cri inarticulé qui semblait la voix de la lumière' (Apollinaire, 1959, CEuvres poétiques, 33).

5 This chapter follows many years spent working on bestiaries that culminated in my Animal Skins and the Reading Self in Medieval Latin and French Bestiaries (Kay, 2017). The parts of this book that relate most closely to the present chapter are Chapter 1 (about the bestiary and the book) and the Appendix (my understanding of the evolution of the genre).

6 All references to The Bestiary or the Procession of Orpheus by Graham Sutherland are to the aquatints of 1978-9.

7 Physiologus, xii.

8 See, for example, McCulloch 1960.

9 This famous bestiary can be seen online at https://www.abdn.ac.uk/bestiary. Another, the bestiary in the Bodleian Library, Bodley 764, has been translated into English and then printed with the pagination and illustrations of the original: Barber 1992.

10 In their notes to the text of the Pléiade edition, Marcel Adéma and Michel Décaudin acknowledge 'le souvenir de la poésie emblématique du Moyen Age et de la Renaissance' (1028). They trace the origins of Apollinaire's interest in a bestiary to 1906 (with Picasso envisaging but ultimately not pursuing this project) and 1908 (when Apollinaire published $L a$ Marchande des quatre saisons ou le bestiaire mondain, a sequence of 18 poems that overlap substantially with Le Bestiaire ou Cortège d'Orphée). Only in 1910 did he begin the collaboration with Dufy, at the same time expanding the number of animals and reassigning the poems earlier associated with La Marchande to Orpheus (Apollinaire, 1959, OEuvres poétiques, 1027).

11 See Matthew Senior, in this volume, on the implications of the more mechanised view of nature in Sutherland's Bestiary.

12 See, for example, McCulloch 1960 and Baxter 1998.

13 See note 10 above for earlier forms of the work.

14 For discussion, see, for example, Kay 2015. 
15 For text, translation and study of this version, see Clarke 2006. For an example of this layout in sections marked by enlarged paintings, see Barber 1992.

16 Pymander, 2.6-7: 'a certain Holy Word joined itself unto Nature, and out flew the pure and unmixed Fire from the moist Nature upward on high .... And the Air which was also light, followed the Spirit and mounted up to Fire (from the Earth and the Water) insomuch that it seemed to hang and depend upon it. 7. And the Earth and the Water stayed by themselves so mingled together, that the Earth could not be seen for the Water, but they were moved, because of the Spiritual Word that was carried upon them.'

17 Apollinaire, 1959, CEuvres poétiques, 10.

18 Apollinaire, 1959, CEuvres poétiques, 13.

19 Apollinaire, 1959, OEuvres poétiques, 28, 20; three of the insects are in some way related to poetic activity: the caterpillar, the fly and the grasshopper.

20 Apollinaire, 1959, CEuvres poétiques, 8, 9.

21 Some of BnF NAF 25609 is transcribed by the editors (Apollinaire, 1959, OEuvres poétiques, 1028), along with other animal variants (Apollinaire, 1959, CEuvres poétiques, 1029).

22 Apollinaire, 1959, OEuvres poétiques, 7.

23 For the publication history, see the Pléiade edition (Apollinaire 1959), 1185-6.

24 The most influential of these is ascribed to one Theobaldus: Theobaldi Physiologus. Introduction, critical apparatus, translation and commentary (edited by Eden 1972).

25 Compare, in particular, the equivalent chapters in Theobaldi Phsyiologus (edited by Eden 1972): 24-6, 64-6.

26 Apollinaire, 1959, CEuvres poétiques, 14.

27 Muratova 1977.

28 On The Ibis and elegy, see Sarah Spence's essay in this volume.

29 Ez. 1: 4-14: 'And I looked, and, behold, a whirlwind came out of the north, a great cloud, and a fire unfolding itself, and a brightness was about it ... and out of the midst thereof came the likeness of four living creatures. And this was their appearance; they had the likeness of a man. And every one had four faces, and every one had four wings, as for the likeness of their faces, they four had the face of a man, the face of a lion on the right side: and they four had the face of an ox on the left side; they four also had the face of an eagle.'

30 See the role of animals, including the ox, in a Jewish Apocalypse, as analysed by Agamben 2004, Chapter 1. Sirens can also appear in the iconography of Apocalypse; see Travis 2002.

\section{Bibliography}

University of Aberdeen. The Aberdeen Bestiary. https://www.abdn.ac.uk/bestiary

Agamben, G. 2004. The Open. Man and Animal, translated by Kevin Attell. Stanford: Stanford University Press.

Apollinaire, G. 1959. OEuvres poétiques, edited by Marcel Adéma and Michel Décaudin. Paris: Pléiade.

Barber, R 1992. Bestiary: Being an English Version of the Bodleian Library, Oxford, MS Bodley 764 with all the original miniatures reproduced in facsimile. London: Folio Society.

Baxter, R. 1998. Bestiaries and Their Users in the Middle Ages. Thrupp: Sutton Publishing, and London: Courtauld Institute.

Clarke, W.B. 2006. A Medieval Book of Beasts. The Second Family Bestiary. Commentary, Art, Text and Translation. Woodbridge: Boydell and Brewer.

Curley, M.J. (editor and translator) 2009. Physiologus. Second edition. Chicago: University of Chicago Press.

Eden, P.T. (editor) 1972. Theobaldi Physiologus. Introduction, critical apparatus, translation and commentary. Leiden: Brill.

Hermes Mercurius Trismegistus. 1650. The Divine Pymander of Hermes Mercurius Trismegistus an Egyptian Philosopher. London: Robert White. https://cdn.website-editor.net/e4d6563c50794 969b714ab70457d9761/files/uploaded/DivinePymanderOfHermesMercuriusTrismegistus\% 2CThe.pdf

Kay, S. 2015. 'Before the animot. Bêtise and the zoological machine in Medieval Latin and French bestiaries', Yale French Studies 127: 34-51. 
Kay, S. 2017. Animal Skins and the Reading Self in Medieval Latin and French Bestiaries. Chicago: University of Chicago Press.

McCulloch, F. 1960. Mediaeval Latin and French Bestiaries. Chapel Hill: University of North Carolina Press.

Muratova, X. 1977. “'Adam donne leurs noms aux animaux." L'iconographie de la scène dans l'art du Moyen Âge: les manuscrits des bestiaires enluminés du XIIe et du XIIIe siècles', Studi medievali 18: 367-94.

Sutherland, G. 1968. A Bestiary. London: Marlborough Fine Art.

Sutherland, G. 1977. Bees. London: Marlborough Fine Art.

Travis, W.J. 2002. 'Of Sirens and Onocentaurs: A Romanesque Apocalypse at Montceaux-l'Etoile', Artibus et Historiae, 23.45: 29-62. 


\title{
3
}

\section{Ombre terreuse: Shades of meaning in Vergil, ovid and Apollinaire}

\author{
Sarah Spence
}

In his poem 'Orpheus alone', Mark Strand represents Orpheus as composing the very first three poems. ${ }^{1}$ They are pegged to the tenses: the first is the poem of the past that describes his lost wife Eurydice as she was in life:

Her forehead where the golden light of evening spread, The curve of her neck, the slope of her shoulders, everything Down to her thighs and calves, letting the words come, As if lifted from sleep, to drift upstream, Against the water's will.

The second is the poem of the present, detailing the moment of return from the underworld, when Orpheus wandered the hills:

... until he had shaken

The image of love and put in its place the world As he wished it would be, urging its shape and measure Into speech of such newness that the world was swayed, And trees suddenly appeared in the bare place Where he spoke.

And to these Strand adds a third, which is really the afterlife of Orpheus's poetic journey, a song of the future:

The third and greatest

Came into the world ... 
As things come that will perish, to be seen or heard

Awhile, like the coating of frost or the movement

Of wind, and then no more ... it came in a language

Untouched by pity, in lines lavish and dark, where death is reborn and sent into the world as a gift,

So the future, with no voice of its own, nor hope

Of ever becoming more than it will be, might mourn.

I propose to use this taxonomy of tenses to investigate the ways Orpheus has appeared in a range of poems from Vergil to Guillaume Apollinaire. The Augustan poets who write most about Orpheus, Vergil and Ovid share with Apollinaire a conviction that, at least in part because of Orpheus, poetic language illuminates loss by creating, inhabiting and importing shade. Moreover, the very ability to import shade from the underworld derives from an even earlier portrayal of Orpheus as the poet of the natural world. In Vergil and Ovid, the Orpheus myth serves to map out a new genre, the elegy, as Orpheus becomes a new kind of poet through his journey in search of Eurydice, a journey predicated on an earlier role. But, as a result, these poets focus mostly on the past and present. In Apollinaire, the poems, and their visual counterparts by Raoul Dufy and Graham Sutherland, play with the role and importance of various kinds of boundary crossing, while also shifting the focus towards the future and reception. In the end, Orpheus can be seen as the poet who, by crossing to death and back, brought shade and darkness into the poetic conversation of the living, a move made possible by his early role as nature's maestro.

Initially, of course, Orpheus was the poet of nature not love. His first literary appearance is in Simonides, who describes the birds flying overhead and fish leaping from the sea in time to Orpheus's music. ${ }^{2} \mathrm{He}$ gains prominence as the figure of the poet gains prominence: he is photoshopped into the Trojan War by Apollonius's addition of him to the Argonauts, a tale that provides the prequel to Homer's epics (where, strikingly, Orpheus does not appear). But in Apollonius he is there, and prominently so:

[1] Beginning with thee, O Phoebus, I will recount the famous deeds of men of old, who, at the behest of King Pelias, down through the mouth of Pontus and between the Cyanean rocks, sped wellbenched Argo in quest of the golden fleece ...

[18] The ship, as former bards relate, Argus wrought by the guidance of Athena. But now I will tell the lineage and the names of 
the heroes, and of the long sea-paths and the deeds they wrought in their wanderings; may the Muses be the inspirers of my song!

[23] First then let us name Orpheus whom once Calliope bore, it is said ... Men say that he by the music of his songs charmed the stubborn rocks upon the mountains and the course of rivers. And the wild oak-trees to this day, tokens of that magic strain, that grow at Zone on the Thracian shore, stand in ordered ranks close together, the same which under the charm of his lyre he led down from Pieria. Such then was Orpheus whom Aeson's son welcomed to share his toils ... ${ }^{3}$

This poet-hero has nothing to do with Eurydice, and in fact Eurydice plays only a small part in the history of Orpheus overall. While the story of Orpheus and Eurydice's relationship, her death and his failed attempt to recover her from the underworld is prominent in Augustan poets, especially Vergil and Ovid, Eurydice is a relatively new addition to the story of Orpheus, since she is not named until the second century BCE lament for Bion (ascribed to a student of his), although she is alluded to in Euripides's Alcestis (438 BCE) and briefly in Plato's Symposium (385-370 BC): ${ }^{4}$

In this manner even the gods give special honor to zeal and courage in concerns of love. But Orpheus, son of Oeagrus, they sent back with failure from Hades, showing him only a wraith of the woman for whom he came; her real self they would not bestow, for he was accounted to have gone upon a coward's quest, too like the minstrel that he was, and to have lacked the spirit to die as Alcestis did for the sake of love, when he contrived the means of entering Hades alive. Wherefore they laid upon him the penalty he deserved, and caused him to meet his death ...

After the Augustan poets, Eurydice again drops from view in the early Christian representations, such as those in the catacomb paintings in Rome, where stories of Orpheus are focused entirely on his powers with the animals.

Much more prominent in the history of the figure, then, are the magical powers of Orpheus the poet, and I think we need to set the story of Eurydice in this context: see it, in others words, as just one instance of a larger pattern or story. ${ }^{6}$ If we choose to see Orpheus as poet first, lover second, we can then perhaps understand him as acquiring a new form of 
song through his trip to the underworld. Support for this approach is offered, I would argue, by Ovid (43 BCE-17 CE) who points back, as so often, to his source in Vergil (70-19 BCE). In book 10 of his epic Metamorphoses (Met. 10), Ovid responds to Vergil's tale from Georgic 4 (Geo. 4), retelling the story with slight variations. While those variations have been studied at length, there are further resonances to be teased out. Particularly significant, I think, is the use of shade in each. When Ovid's Orpheus surfaces from the underworld in Met. 10, he climbs a hill which is described as lacking shade (line 88); but by gathering trees around him, he has created in the space of two lines a site for singing - a site described, above all, as shaded (line 90):

There was a hill, and, on the hill, a wide area of level ground, turfed with fresh blades of grass: shade was absent there: but when the poet, born of the god, sounded the strings of his lyre, shade gathered there.

Collis erat collemque super planissima campi area, quam viridem faciebant graminis herbae: umbra loco deerat; qua postquam parte resedit dis genitus vates et fila sonantia movit, umbra loco venit.

(Ovid, Met. 10. 86-90)

In the Latin the contrast is clear: 'Umbra loco deerat' begins the one line, 'Umbra loco venit' the other. Orpheus's singing, following his trip to the underworld, turns a site barren of shade into one where song happens, one marked by shade. (Note that he does not create the trees here, just the shade):

Jupiter's Chaonian oak tree came; and Phaethon's sisters, the Heliades, the poplars; the durmast oak with its deep foliage; the soft lime-tree; the beech; the virgin sweet-bay, laurel; the hazel, frail; the ash-tree, used for spears; the sweeping silver-fir: holm-oak, heavy with acorns; pleasant plane-tree; the manycoloured maple; with the river-haunting willow; lotus, water-lover; boxwood ever-verdant; the slender tamarisk; the myrtle, with, over and under its leaves, the two shades of green; and the blueberried wild bay, Laurus tinus. You came, also, twining ivy, together with shooting vines; the vine-supporting elms; the flowering 'manna' ash; the spruce; the strawberry tree, weighed down with 
its red fruit; the pliant palms, the winner's prize; and you, the shaggy-topped pine tree, armed with needles, sacred to Cybele, mother of the gods, since Attis exchanged his human form for you, and hardened in your trunk.

non Chaonis afuit arbor, 90

non nemus Heliadum, non frondibus aesculus altis, nec tiliae molles, nec fagus et innuba laurus, et coryli fragiles et fraxinus utilis hastis enodisque abies curvataque glandibus ilex et platanus genialis acerque coloribus inpar

amnicolaeque simul salices et aquatica lotos perpetuoque virens buxum tenuesque myricae et bicolor myrtus et bacis caerula tinus. vos quoque, flexipedes hederae, venistis et una pampineae vites et amictae vitibus ulmi ornique et piceae pomoque onerata rubenti arbutus et lentae, victoris praemia, palmae et succincta comas hirsutaque vertice pinus, grata deum matri, siquidem Cybeleius Attis exuit hac hominem truncoque induruit illo.

(Ovid, Met. 10. 90-105)

The setting for shade is here created by Orpheus's trip to Hades. The word umbra, shade, is also significant, since it bears the same double valence in Latin that it does in English: the figures Orpheus encounters in the underworld are 'umbrae'; the cool spot for singing under the trees is one of shade (umbrae).

Ovid emphasises the word umbra, and Ovid's emphasis helps us note retroactively an interesting doublet in Vergil: in the Georgics, when Orpheus first arrives in the underworld, the shades (umbrae) gather around him, "like birds clustered in the leaves at night or during a winter storm'. These shades are present here, literally as ghosts. But at the end of the tale, the word shows up again, this time with the other sense of shade:

just like the nightingale, mourning under the poplar shade laments her lost offspring, whom the harsh farmer, seeing the fledglings in the nest, knocked down; but she weeps through the night and weaves her sad song, sitting on a branch, and fills the places far and wide with her sad laments. 
qualis populea maerens philomela sub umbra amissos queritur fetus, quos durus arator observans nido implumes detraxit; at illa flet noctem ramoque sedens miserabile carmen integrat et maestis late loca questibus implet.

(Vergil, Geo. 4. 511-5)

It is my argument that Vergil's Orpheus encounters umbrae in the underworld and returns with them as part of his poetic kit. Moreover, Vergil suggests this difference by the types of songs sung before and after Orpheus's journey. While the song at the end that the sorrowful bird sings includes markers of elegy (the bird laments her lost offspring, destroyed by the farmer, a song that continues into the night; the song is marked by a pastoral or georgic (non-epic) setting, and one that weaves and fills up the landscape), the song that launches the story of Orpheus and Eurydice, before the shade is present, is quite different:

[T] he chorus of Dryads filled the high mountains with their clamor; the Rhodopeian crags and the lofty Pangaea and the martial land of Rhesus and the Geta and the Hebrus and Actian Orithyia weep. He accompanying his sad love with the hollow tortoise shell was singing 'you, sweet wife, you' by himself on the lonely shore, 'you with the rising sun, you with the setting'.

He enters the Taenarian passage, the lofty shores of Dis, and the grove, dense with black fear; he confronts the souls and the fearful king and hearts unable to grow soft by human prayer.

At chorus aequalis Dryadum clamore supremos implerunt montes; flerunt Rhodopeiae arces altaque Pangaea et Rhesi mavortia tellus atque Getae atque Hebrus et Actias Orithyia. Ipse cava solans aegrum testudine amorem te, dulcis coniunx, te solo in litore secum, te veniente die, te decedente canebat. Taenarias etiam fauces, alta ostia Ditis, et caligantem nigra formidine lucum ingressus manesque adiit regemque tremendum nesciaque humanis precibus mansuescere corda.

(Vergil, Geo. 4. 460-70) 
Here there is no shade. The song both Orpheus and the poet sing is strikingly at odds with its setting, full of Dryads and epic broad landscapes. Neither space nor time seems to suit the song: it is as if Orpheus at this point before his descent can only sing an epic song about his love.

Vergil's interest with Orpheus extends into his epic Aeneid (Aen.), especially in two spots: the last night in Troy, where Creusa becomes a Eurydice figure (in some versions she is called Eurydice) as Aeneas returns to try to save her; and at the beginning of the second half of the poem, as Aeneas leaves the Underworld and travels up the coast to Latium. Through alluding to the Orpheus tale on the last night of Troy, Troy becomes identified with Hades, Aeneas with Orpheus, and his heroic role tinged not just with love, but with both love and to a certain extent loss. Aeneas loves his wife Creusa and he goes back for her when she goes missing; yet he fails to retrieve her and he leaves with a prophecy from her and a sense of loss - of Troy, of life as he knows it, of his wife even though it is a loss he barely refers to again. The strongest link with the myth is really through Eurydice not Orpheus, since there is no follow up to this story, no further elegy written or sung by Aeneas about Creusa.

The second instance is different. Here Aeneas seems unable to shake off his identification with Orpheus, as the story from Geo. 4 is recalled as Aeneas leaves the underworld behind and exits to the world of Rome. Like Orpheus in the Georgics, Aeneas returns from the underworld into a landscape that is more elegiac than epic, a landscape marked by death, loss and lyric poetry. Once he leaves Cuma at the end of book 6, he travels up the coast; it is a coast marked by death and loss, as book 7 opens with the tag 'Tu quoque', which introduces death into the land of the living through lamentation over the burial of Aeneas's nurse.

Both Ovid and Vergil use the Orpheus story to meditate on what he retains after his journey, not what he loses: for Ovid, Orpheus's return creates shade; for Vergil, the shade-filled song after he returns is better suited to its dark theme than the epic one at the start. For both Augustan poets, the shades encountered in the underworld are semantically packed into Orpheus's return luggage and resurface after the journey, like so much sand from Hawaii, to enhance his role as poet. For both, shade crosses back over the border between that world and this, a crossing that insists on the role of death in poetry. Ovid emphasises the shade; Vergil the poetry of shade, the elegy. ${ }^{8}$

Clearly influenced by Ovid to some extent and Vergil more, Mark Strand, as I have, mentions the creation both of shade and of the poetry of shade, and even alludes to the two stages of Vergil's poems: those of the past and the present. Injecting darkness into poetry, or insisting 
on the importance of that darkness, is Orpheus's role, as Strand understands it and as I have also argued, and this darkness plays a role in more modern versions of the Orpheus story as well. The woodcuts of Raoul Dufy that illustrate the poems of Apollinaire known as Le Bestiaire ou Cortège d'Orphée $e^{9}$ show evidence of this darkness. The very nature of a woodcut reverses the prominence, literally, of dark and light: whereas in painting, the shade and darker tones often provide the negative space that creates the shape, in woodcuts it is the opposite: the light is the recessed, negative space that offsets the dark images; what is carved out becomes light, what is left untouched, dark. So too, I would argue, with the poems: just as the woodcuts are framed symmetrical spaces that show patterns of dark on light, so the poems are carefully wrought symmetrical verses edged by their rhymes that play with the dark on the light, the word on the page. The woodblock of The Tortoise shows the strings of the lyre (are they the white lines

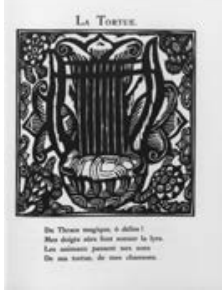
or the black?) which are likened in the poem to the lines of the verse: 'Les animaux passent aux sons / De ma tortue, de mes chansons' ('The animals parade through the sounds of my tortoise shell, of my songs'). Like the woodcuts, the poems I will discuss offer the play of dark on light, and the dark is often as present as the light (illustration 2).

And in keeping with Strand's taxonomy, the future is strikingly at issue in Apollinaire. The clearest example here is Apollinaire's 'Ibis'

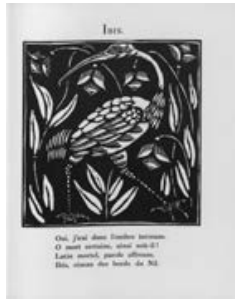
poem: its Latinate title, Ibis, 'Thou Shalt Go', with its response in the opening line, 'Oui, j'irai', dissolves the animal into a commandment, but a positive one. ${ }^{10}$ Rather than the worst-10 list, the 'thou shalt nots' of Moses's tablets, this one commandment states the single indisputable fact of life: you will indeed die (illustration 7):

Oui, j'irai dans l'ombre terreuse,

O mort certaine, ainsi soit-il!

Latin mortel, parole affreuse,

Ibis, oiseau des bords du Nil.

Indeed, I shall enter the shadow of earth,

O certain death, so be it!

Dying language, dreadful word,

Ibis, bird of the Nile's shores. 
In this poem, Apollinaire's 'bords du Nil', given the Latinised context of the title and response of the first line, becomes both a border of a river and the edge of nothingness, as it posits a similar crux where dark and light coexist and are mediated through wordplay. The crossing for Apollinaire is inevitable; the value and benefit remain an unknown and, as with the Augustan poets, a potential gain. In this context, then, it is striking that Apollinaire's focus is on the journey out rather than the return: ibis (which, probably coincidentally, echoes Ovid's epyllion of the same name about his exile to Pontus). Perhaps because of the earlier Orpheus poems, Apollinaire's poetry talks about one world in the context of the other, of Latin in the context of French, death in the context of life (is it pushing it too far to suggest that 'ombre terreuse' includes echoes of both types of shade?). Apollinaire draws from earlier journeys of Orpheus and asserts that loss is a facet of - or even resides in - poetic language and, as Strand so aptly points out, in a poetry that enables us to mourn.

Apollinaire's friend and colleague Max Jacob posits what the poet and critic Rosanna Warren has called a 'savage poetics' that mixes sacred and profane and presents an art of 'de-formation'. In ways that echo Strand's temporal division of the Orpheus poems, Warren suggests that for Jacob 'the wreckage of the poetry of the past' offers the source of the poetry of the future. His poems appear traditional and yet are disruptive. And she credits Jacob with teaching Apollinaire how to be Apollinaire how to escape 'nineteenth-century crooning' and create something revolutionary and disruptive. Much of this, I would suggest, is on offer in Le Bestiaire: while the traditional is certainly present (both classical and Christian themes and a strict limited form and meter), we find cutting across these bonds disruption, disintegration and transformation of the classical works. ${ }^{11}$

To start with something simple: the black on white of words on the page that mirrors the woodcuts of Dufy is something unavailable to the audience of Vergil and Ovid and before. The notion that the poem can in fact enact the struggle between dark and light - a struggle made clearer by the woodcuts - is nontraditional or at least nonclassical. We have seen this at work in 'La Tortue', yet it appears again in 'Le Poulpe' and, in slightly different form, in 'L'Éléphant'. The ink on the page is the words of his song, his treasure.

More significantly, Apollinaire's decision to write of Orpheus at all, I would argue, disrupts at least one of his roles in the classical poems: there Orpheus is above all a poet of sequence and con-sequence, linked as he is with beginnings and endings, with life and death, but also with the narrative thrust of Augustan elegy. Apollinaire's Orpheus does 
none of this: there is no narrative arc to the bestiary, and Orpheus himself does not occupy a defined role. On the contrary, his voice floats through time and space, and sometimes is that time and space, as he both sings of the world and is the song. For example, in 'Le Chat' he sings of a domestic scene, whereas in 'Les Sirènes' he is the sea and his age, the ships on the water of his life. Things of the present and the past, of near and far are treated as if they are all present in the here and now: the mouches of Norway jostle next to Jason's golden fleece, which in turn is likened to the hair of his beloved. He is Christ reborn, as he is in the catacomb paintings, and he is envious of death: 'Est-ce que la mort vous oublie?'

With origins erased, or at least downplayed, another aspect of Orpheus's role shifts as well. As we have seen, in many of the ancient poems he is represented again and again as bringing death to life, granting voice to the dark, creating elegy; in Apollinaire, this originary role is either assumed or denied him. Death is already present. It is there in the ink, with the carp, and while sometimes it is represented in the lines as the light of rebirth, often it just lives on the page, in the lines of poetry and the woodcuts, as darkness - as Strand says, the poem where 'death is reborn and sent into the world as a gift'. Death is already part of the poetic vocabulary, functioning like the frame around each of the woodcuts; Orpheus here is not charged with making the trek to the underworld and bringing shade back for the benefit of poets who follow along later. He instead serves as a reminder of the death he has witnessed, a death that is inevitable.

Apollinaire's Orpheus, then, is still a poet of shade and dark, just as he became in Vergil and Ovid, but it is a dark that is already present: it is there throughout the poems; it is there throughout time and throughout the world. It is what unites the animals and connects them to the poet and his poems: the darkness of the ink on the page, the darkness of the end of life, the darkness so prominent in the woodcuts. The carp, after all, is pitied for not being able to die.

It is, in fact, the animals that for me disappear in the poems with the woodcuts, but are then brought back into the discussion by Graham Sutherland's aquatints. These watercolours also illustrate the poems of Apollinaire, but in a very different way. In Sutherland, colour and light play a more prominent role than in Dufy. While the dark tone is still sometimes there - the octopus and the grasshopper are perhaps the most obvious examples - and the frame is still hinted at in, for example, the elephant and the lion, Sutherland is responding to something different in Apollinaire. While the Dufy seems to me to illustrate the poems, the Sutherland does not. The older characterisation of Orpheus 
conducting nature, causing animals, plants and rocks to move in time to his music, seems to me to be what is driving Sutherland. An emphasis on motion predominates - whether it is the caterpillars or serpent breaking through the barriers, or the ibis flying. Some of the images have frames, as in the image of Orpheus at the start, or even in a sense the lion's cage, but those frames lose their substance the longer you stare at them: Orpheus turns out to be surrounded by vital organic matter, not a static frame, and the cage is clearly a painterly
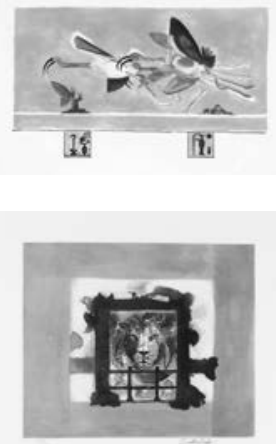
line with no dimension. This Orpheus shows himself in the action of the animals and the energy of the images, often collage-like in their juxtapositions. The elephant, for instance, spews water over his body, his ivory tusks gleaming; this in turn is juxtaposed to the poet's mouth, with its equally gleaming ivories. In a further turn, this becomes or is generated by the abstractions at the top of the page: visual strokes that echo but do not reproduce the sounds below (illustrations 19 and 11).

For Sutherland, the power of Orpheus as poet seems to be to make the juxtaposition of registers possible, a facet of Apollinaire not drawn out by Dufy. As nature's maestro, Orpheus does not so much organise and control nature as he enables music and poetry to recur in multiple forms simultaneously. So Sutherland's mouse, for instance, gnawing at the wood, 'ronge[ant] peu à peu ma vie', is set beside a candle that likewise burns through time, and the moon whose setting will send the mouse scurrying away - an action shown in the bottom register of the print. As prints, not woodblocks, the impression is made 'by [a] method

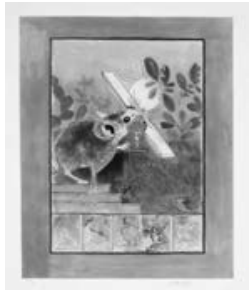
involving transfer from one surface to another. ${ }^{12}$ As the image is transferred, so it speaks to Orpheus's role in moving across barriers. Sutherland's focus is on the movement across that edge, the transfer between surfaces. This uncovering of resonances across media is more collage than synaesthesia and makes us see something different in Apollinaire (illustration 12).

Strikingly, while the earlier version of the Orpheus myth of Orpheus as nature's maestro is not prominent in the Augustan poets, it is there at a spot that resonates with the Sutherland. In both Vergil and Ovid, nature is present at the border between life and death and it provides access into poetic space, entry into the elegy Orpheus's 
journey ultimately creates. In Ovid, Orpheus's return trip is marked by the mention of two metamorphoses, both into rocks, and then by the catalogue of transformed trees we saw earlier. In the Vergil, the shades are likened to birds, suggesting resonance across very different fields of existence:

But with his singing, the slender shades and ghosts lacking light arrived, moved, from the deep seats of Erebus, just as a thousand birds bury themselves in the leaves when night or winter storms drive down from the mountains.

At cantu commotae Erebi de sedibus imis umbrae ibant tenues simulacraque luce carentum, quam multa in foliis avium se milia condunt vesper ubi aut hibernus agit de montibus imber.

(Vergil, Geo. 4. 471-74)

These birds strikingly echo the bugs described in the second Orpheus poem in the Apollinaire, especially as illustrated by Sutherland:

Regardez cette troupe infecte

Aux mille pattes, aux cent yeux:

Rotifères, cirons, insectes

Et microbes plus merveilleux

Que les sept merveilles du monde

Et le palais de Rosemonde!

Observe this undone multitude

A thousand feet, a thousand eyes:

Rotifers, chyrons, insects

And microbes more wonderful

Than the seven wonders of the world

And the palace of Rosamund!

And at the end, the poet himself is likened to the nightingale mourning her lost offspring, similar to Apollinaire's identification with the Octopus:

Jetant son encre vers les cieux,

Suçant le sang de ce qu'il aime

Et le trouvant délicieux,

Ce monstre inhumain, c'est moi-même. 
Spurting its ink toward the sky,

Sucking the blood of what it loves

And finding it delightful,

This inhuman monster, it is I.

This similarity is brought to the fore by Sutherland's depiction of The Octopus, where eight digits, two glassy eyes and stem and domed head resonate across the animal kingdom.

But perhaps most striking is the association Vergil makes between Aeneas and Orpheus, one that takes us back to the earlier Orpheus stories we examined. As we have seen, other versions of this myth, including Vergil's in Geo. 4, enact the pairing of loss and desire through Orpheus singing, especially to the natural world, after he leaves the underworld. In the Aeneid, Vergil offers no such song, yet that elegiac moment is not missing altogether: as Aeneas travels up the coast of Italy, he sails by the land of Circe, who has mesmerised the animals much as Orpheus is said to in other accounts:

They pass close by the shore where Circe, she

Who is the daughter of the Sun, in her

Secluded grove sings on unceasingly,

Her proud house lighting the darkness with lamps of cedar

Shedding their fragrance on the evening air,

As her shuttle shrills upon the web she weaves.

As they pass by they hear upon the shore

The roaring of lions furious at their chains,

And the raging of bristling boars and caged-up bears,

And the ululating howls of enormous wolf-shapes.

These are the men whom the cruel goddess Circe

Had with her herbs and potions turned into beasts,

Robbing them of their humanness with her witchcraft.

But father Neptune, so that the Trojans would

Not suffer the monstrous fate they would have suffered

Had they been brought into that harbor and

Had they set foot upon that shore, saw to it

That they were gotten past those seething shallows,

Keeping them safe. Then, as the morning's first

Rays of light were making the waters redden,

And high in the heavens in her roseate chariot

Aurora shone in the saffron light, the wind

Dropped suddenly, all the breezes, and, 
Propelled only by oars, slowly they moved

Themselves along through the marbled quieted waters.

(translated by David Ferry)

proxima Circaeae raduntur litora terrae,

dives inaccessos ubi Solis filia lucos

adsiduo resonat cantu, tectisque superbis

urit odoratam nocturna in lumina cedrum

arguto tenuis percurrens pectine telas.

hinc exaudiri gemitus iraeque leonum

vincla recusantum et sera sub nocte rudentum,

saetigerique sues atque in praesepibus ursi

saevire ac formae magnorum ululare luporum,

quos hominum ex facie dea saeva potentibus herbis

induerat Circe in vultus ac terga ferarum.

quae ne monstra pii paterentur talia Troes

delati in portus neu litora dira subirent,

Neptunus ventis implevit vela secundis,

atque fugam dedit et praeter vada fervida vexit.

(Vergil, Aen. 7. 10-24)

I would suggest in the context of these lines we are meant to think back to Orpheus as he was originally depicted, the Orpheus of Simonides or Apollonius: a poet-hero marked by power. These animals, though, obey another; this Orpheus is not that kind of poet-hero. Instead, Vergil suggests, his poet-hero is marked by loss. While a hero when he wins gains victory, a hero of loss gains loss, and a poet-hero of loss gains the poetry of loss as his superpower. Orpheus gains as a poet from his trip to the underworld. What Orpheus - and Aeneas acting like Orpheus brings back from the underworld is the traces of death and mortality, the umbra that marks both setting and tone of his take on elegy. For the Augustan poets, the animals and the allusion to Orpheus's early role lurk at the point of transition between life and death. To put this slightly differently, it is, for the Augustans, the history of Orpheus's poetic ability to communicate across the boundary between man and nature that makes him able to travel to the underworld and back. This history becomes the passage itself: he was a poet before he was a poet of death, a fact Sutherland seems to revel in.

Writers have spoken of Sutherland's interest in the metamorphic, ${ }^{13}$ and I think in a way it is fair to suggest, finally, that Sutherland does see Orpheus more as Ovid does, Dufy more like Vergil. Emphasis on the dark, 
on death and loss, befit Dufy and Vergil; stress on the ability to cross realms, to metamorphose, fits better with Ovid and Sutherland. Ovid's death of Orpheus is possibly the best illustration of this: women dressed in leaves and branches tear him limb from limb and pelt him with rocks. He becomes a shade (Met. 11. 61), but not before he charms the missiles tossed at him (Met. 11. 9-13) (until their sounds overpower his) and his head, removed from his body, retains the power of song. While the darkness and shade are there, the emphasis in the end is on his power as a poet: first over nature, then in the face of death. The poetry remains despite - or even because of - the shifting of registers. In Ovid, Orpheus, after he dies, returns to the Underworld and to Eurydice, where the pair are described as taking turns leading and following. Vergil's Orpheus was not granted such a happy ending; his story focuses on the loss that is brought back from death. So, too, the Dufy engravings stress the dark limits, while the Sutherland, like the Ovid, breaks through those limits and revels in the transformative power afforded by nature, poetry and paint. While the Dufy illustrations translate the Apollinaire into visual terms in often striking and powerful - if metonymic - ways, the Sutherland works in the juxtaposition of collage and of metaphor, where the disruption of the visual field echoes the disruption of the inherited powers of Orpheus, and the beautiful new balance of the collage-like page suggests the persistence of Orpheus as poet who can move across boundaries that include, but are not limited to, the borders of life and death. Both Dufy and Sutherland, as well as Apollinaire, offer an Orpheus who creates a poetic language for the future, a language which, as Strand concludes, will mean that:

the future, with no voice of its own, nor hope

Of ever becoming more than it will be, might mourn.

\section{Notes}

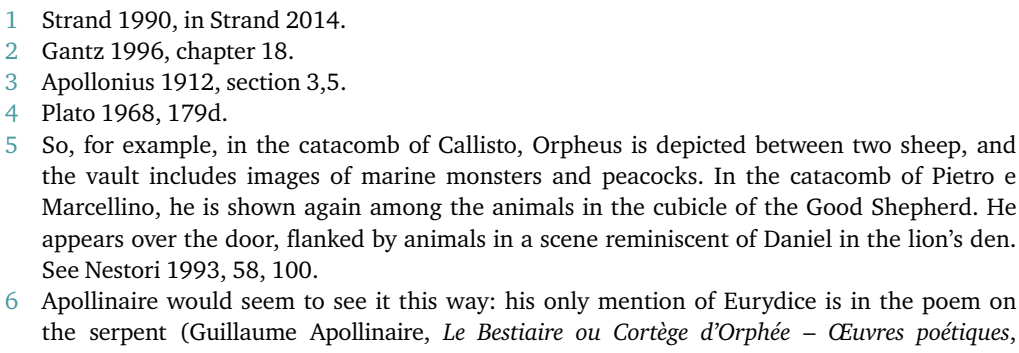
the vault includes images of marine monsters and peacocks. In the catacomb of Pietro e Marcellino, he is shown again among the animals in the cubicle of the Good Shepherd. He appears over the door, flanked by animals in a scene reminiscent of Daniel in the lion's den. See Nestori 1993, 58, 100.

6 Apollinaire would seem to see it this way: his only mention of Eurydice is in the poem on the serpent (Guillaume Apollinaire, Le Bestiaire ou Cortège d'Orphée - CEuvres poétiques, 
Apollinaire 1975, 7), where Eurydice is mentioned with other women, including Eve and Cleopatra, whom the serpent destroyed. In this poem there is no explicit mention of Orpheus and no indication that Eurydice is important to Apollinaire's understanding of the poet.

7 The translation is that of A.S. Kline, available at http://ovid.lib.virginia.edu/trans/Ovhome. htm\#askline

8 Note that shade is strikingly absent from Dante's underworld: Dante himself is the only character who casts a shadow.

9 Apollinaire 1975.

10 Apollinaire 1975, 31.

11 Quotations from a lecture by Rosanna Warren, 'Translation as Literary Biography: The Case of Max Jacob', delivered at the Translation Seminar, Rethinking Translation, Mahindra Humanities Center, Harvard University, December 2017.

12 Tate Gallery 1988, 457-8, 463.

13 Tate Gallery 1988, 458.

\section{Bibliography}

Anderson, W.S. 1972. Ovid's Metamorphoses. Books 6-10. Norman: University of Oklahoma Press. Apollinaire, G. 1975. CEuvres poétiques. Bibliothèque de la Pléiade 121. Paris: Gallimard.

Apollonius. 1912. The Argonautica, translated by R.C. Seaton. Cambridge, MA: Harvard University Press.

Arrowsmith, W. 1974. Alcestis. New York: Oxford University Press.

Bravi, L. 2006. Gli epigrammi di Simonide e le vie della tradizione (Filologia e critica ; 94). Roma: Edizioni dell'Ateneo.

Casali, S. 2017. Virgilio, Eneide 2: Introduzione, traduzione e commento. Syllabus 1. Pisa: Edizione della Normale.

Ferry, D. 2017. The Aeneid. Chicago: University of Chicago Press.

Gantz, T. 1996. Early Greek myth: A guide to literary and artistic sources. Baltimore: Johns Hopkins University Press.

Green, P. 2007. The Argonautika (expanded edition, Hellenistic culture and society; 25). Berkeley: University of California Press.

Hollander, J. 2016. Substance of Shadow: A Darkening Trope in Poetic History, edited by K. Gross. Chicago: University of Chicago Press.

Mazza, T. 2009. Il nuovo Orfeo di Virgilio: Un mito riscritto: Georg. 4, 453-527. Rome: Palombi.

Nestori, A. 1993. Repertorio Topografico delle Pitture delle Catacombe Romane. Roma Sotterranea Cristiana 5. Vatican City: Pontificio Istituto Di Archeologia Cristiana.

Plato. 1968. Symposium, translated by S. Rosen. New Haven: Yale University Press.

Segal, C. 1966. 'Orpheus and the Fourth "Georgic": Vergil on Nature and Civilization', American Journal of Philology 87:307.

Spence, S. 2001. Poets and Critics Read Vergil. New Haven: Yale University Press.

Strand, M. 1990. 'Orpheus alone'. In The Continuous Life. New York: Knopf.

Strand, M. 2014. Collected Poems, 273-4. New York: Knopf.

Tate Gallery. 1988. The Tate Gallery 1984-86: Illustrated Catalogue of Acquisitions Including Supplement to Catalogue of Acquisitions 1982-8. London: Tate Gallery, 1988.

Thomas, R. 1988. Georgics (Cambridge Greek and Latin classics). Cambridge and New York: Cambridge University Press.

Warden, J. 1982. Orpheus, the metamorphoses of a myth. Toronto: University of Toronto Press.

Warren, R. 2016. 'Max Jacob and the struggle for the avant-garde, 1919-1921', Raritan 35:38-70. 


\title{
4 \\ Apollinaire's Octosyllabic Quatrain, Translation and Zoopoetics
}

\author{
Clive Scott
}

The cumulative preoccupations of this chapter are essentially threefold: to ask what kind of verse metabolism the octosyllable - and particularly the octosyllable of Apollinaire's Le Bestiaire ou Cortège d'Orphée - is or has, and to propose that it is a metabolism closely related to the translational act; to suggest that this complicity between octosyllable and translation naturally promotes, in a translation of Le Bestiaire, a metamorphic zoopoetics; and to ask in what specific ways the translator of Apollinaire's octosyllables might further develop this mooted zoopoetics, taking into account the visual languages of Dufy and Sutherland, and the distinction between synaesthesia and intersemiosis.

The opening three poems of Le Bestiaire seem to set an agenda: the poet as Orpheus, polymath, syncretist, harbinger of Christianity and the voices of these personae henceforward are not easily to be put apart - praises Dufy's engravings as the expressive line, as the voice of illumination that emerges from the shadows, possibly the shadows of writing, rather as the two octosyllables $(3>3>2 / 4>4)$ have disengaged themselves from the two trimetric alexandrines ( $4>4>4$ / $3>5>4$ ). ${ }^{1}$ The second poem, 'La Tortue' is in octosyllables: Orpheus's lyre, a gift from Mercury, has a tortoise shell as sound box; the animal, even from beyond the grave, is integrated into, is a collaborator in, is the broadcaster of, Orphic music and song, the music and song to which animals are peculiarly attuned. The third poem, addressed to Pegasus, is accompanied by this commentary: 'Le premier qui monta Pégase fut Bellérophon quand il alla attaquer la Chimère. Il existe aujourd'hui bien des chimères, et avant de combattre l'une d'elles, la plus ennemie de la poésie, il convient de brider Pégase et même de l'atteler. On sait bien ce 
que je veux dire'2 ('The first to mount Pegasus was Bellerophon, when he went after the Chimaera. There are plenty of chimaeras about today and before taking one of them on, the one most hostile to poetry, it's a good idea to put a bridle on Pegasus and even to harness him. You know very well what I mean'). ${ }^{3}$ I take it that the chimaera most hostile to poetry in this temporal and generical context is vers libre, and here Pegasus is bridled by, and harnessed to, the alexandrine, in strict tetrametric livery. Within these three poems we find a set of embryonic principles which help to explain what is for me the self-contradictory nature of Le Bestiaire as a whole: its calling classical values to witness, while keeping an ear open to the temptations of the prosodically transgressive. This is already, for me, to imply a certain strategy for translation: while 'keeping faith' with forebears (source texts), to insinuate into one's versions different voices - voices from elsewhere, voices with different perceptual and expressive ranges, with different kinds of consciousness.

We should, then, immediately note that this formal selfcontradictoriness in Le Bestiaire is haunted, indeed urged, by the voices of the sirens:

Saché-je d'où provient, Sirènes, votre ennui $2>4>3^{\prime}>3$ Quand vous vous lamentez, au large, dans la nuit? $6>3^{\prime}>3$ Mer, je suis comme toi, plein de voix machinées $1>5>3>3$

Et mes vaisseaux chantants se nomment les années. ${ }^{4}$

$4>2>2>4$

[Note: the apostrophe in the syllabic tabulation indicates a coupe lyrique (measure boundary after the word-terminal e atone: 'Sirènes,/votre ennui') rather than the more frequent coupe enjambante (measure boundary before the word-terminal $e$ atone: 'Sirè/nes, votre ennui').]

Are these the voices of another, or the same, chimaera? In any event, Orpheus/Apollinaire is inhabited by them, and in a quite literal sense: the fourth 'Orphée' poem has been infiltrated by the 'mortelles chansons/ Dangereuses et inhumaines' ('mortal songs/Dangerous and inhuman') of 'ces oiseaux maudits' ('these accursed birds'), who, in this poem, have an almost appositional, not merely enumerative, relationship with the female halcyon and 'Amour':

La femelle de l'alcyon, $3>5$

L'Amour, les volantes Sirènes,

$$
2>3>3
$$

Savent de mortelles chansons

$$
1>4>3
$$




$\begin{array}{ll}\text { Dangereuses et inhumaines. } & 3>5 \\ \text { N'oyez pas ces oiseaux maudits, } & 3>3>2 \\ \text { Mais les Anges du paradis. }{ }^{5} & 3>5\end{array}$

Orpheus must stifle their voices with his own, of which, however, they remain a tenacious and never quite eradicable sub-tone. In 'Les Sirènes', which immediately follows 'Orphée [4]' and is directly addressed to the sirens, the poet, through the shared agency of the sea, identifies his plight with theirs. The poet, like the sea, is full of 'voix machinées', including those, one supposes, of the sirens, voices invested with hidden designs and complicities, and conspiratorial residues. At all events, in the poems mentioned thus far, some underlying and apparently conflictual relationship between the alexandrine and the octosyllable is being explored. Of the four poems which take Orpheus as their titular subject, two ([2] and [4]) are in octosyllables, one ([3]) is in alexandrines and one ([1]), as we have seen, is half and half. Do we know what is at stake? This conflict has perhaps three facets: a historical one, in that the octosyllable seeks to recover its lyric indispensability after having been overshadowed, since the mid-sixteenth century, by the alexandrine; a sociopolitical one, in that the alexandrine, as the 'official' line, carries the enunciatory authority and gravitas of the state endorsed, while the octosyllable, an 'unstructured' vers simple (without caesura), a 'body without organs', ${ }^{6}$ speaks to the elusive guerrilla spirit of subversive and mercurial expressivity; and a psycho-physiological one, in that, while the alexandrine still bears the traces of a declamatory and self-ritualising past, the voice of recitation, the rapt voice, the voice of sustained discourse, the octosyllable, for its part, makes room for the multivocal, the vocally experimental, the speaking voice, the voice of changeable tones and inflexions. Again, I would wish to add that translation's own 'voix machinées' engineer constant perceptual adjustment, through different 'languages', towards that inclusiveness which is the token of our embeddedness in the world and the key to our access to the invisible-inthe-visible, the very spirit, perhaps, of a zoopoetics. Translation, seen in this context, is an instance of those crucial shifts of perceptual position, of consciousness, of experiential capacity, by which we absorb ourselves into the world's cognitive diversity.

In his essay on Paul Scarron in Les Grotesques, Gautier expresses the view that '[Le vers de huit syllabes] nous parait plus propre que l'alexandrin, pompeux et redondant, aux familiarités du dialogue, à l'enjouement des 
détails ....' ('[The line of eight syllables] seems to us more suited than the alexandrine, with its pomp and prolixity, to the familiarities of dialogue, to the liveliness of details ...') The internal accents of the octosyllable are rhythmic in the sense that they are mobile, optional, and by no means always correspond with the tonic accent of a so-called mot phonologique. Rhythm is a release from metricality in as much as it invites the paralinguistic to invest the linguistic; and it is multidimensional, too, in that it orchestrates the whole bundle of paralinguistic features - tempo, amplitude, pitch, tone, intonation, quality and degree of accent, degree of the phonation of mute e and degree of liaison, ${ }^{8}$ relative length of vowels - rather than merely concerning itself with syllable number and incidence of accent. Rhythmicity, understood as this paralinguistic investment of the line, is a necessary complement to those other characteristics of the Apollinairian octosyllable, to wit: the constative, the paratactic, the notational, the often casual and désinvolte. Rhythmicity, in this extended understanding, is the instrument of an experimental investigation of expressive resourcefulness, which, I would argue, the octosyllable, and translation, peculiarly invite.

One might think that a rhymed quatrain of octosyllables would constitute, in the terms of Deleuze and Guattari, ${ }^{9}$ courtesy of Boulez, ${ }^{10}$ as striated a space as one might imagine: carefully quantified, measurable, set in a grid against a 'holding' margin. But there is a limit to what this grid can predict for itself. The mere fact that the quatrain is one of a family of stanza structures ensures that we are alert to the potential reconfigurations of its rhyming outline and to its potential morphings into a quintain - the three quintains ('Le Serpent', 'Le Chat', 'Le Dromadaire') in Le Bestiaire all have different rhyme structures - or a sixain - both sixains ('Orphée [2]', 'Orphée [4]') in Le Bestiaire have the scheme ababcc. And we are treated to all kinds of combination of dimetric and trimetric measures, to different densities and distributions of mute 'e's or of particular phonemes. And even within the individual poem, certain anarchic and centrifugal forces seem to be at work, insinuating smooth space into the striated frame. In 'Le Hibou' for instance:

$\begin{array}{ll}\text { Mon pauvre cour est un hibou } & 4>4 \\ \text { Qu'on cloue, qu'on décloue, qu'on recloue. } & 2>3>3 \\ \text { De sang, d'ardeur, il est à bout. } & 2>2>4 \\ \text { Tous ceux qui m'aiment, je les loue. }{ }^{11} & 2>33^{\prime}>3\end{array}$

The confident opening metaphoric declaration unravels into trimetric lines informed by a diction more expressionist in colouring, staccato, 
halting, reinforced by phrase-internal accents d'intention, or contrastive accents, in the second line:

Qu'on cloue, qu'on décloue, qu'on recloue.

and by the coupe lyrique in the final line. The view of the linguist is that 'la diction n'est rien de plus et rien de moins qu'une réalisation phonétique du vers'12 ('the speaking of verse is nothing more nor less than its phonetic realisation'), as if the voice merely followed the instructions already written into the verse. But, on the contrary, the voice is the very agent of smooth space, introducing, into striated space, new flexibilities, revaluations of accentual disposition and degree, of pace and volume, widening margins of tolerance. But more than that. The parataxis characteristic of Apollinaire's verse projects syntax as an additive aggregative procedure, a piece-by-piece patchwork, nomadic, uncentred. In these circumstances what should have argumentative purpose - namely, here, the restrictive relative clause of line 2 - becomes a non-restrictive relative, as if preceded by a comma. And the shared $/ \mathrm{u}$ / of the rhymes begins to act dispersively on the linguistic material, even though the dispositional distinction between /bu/ and /lu/ is clear, and even though the differentiation between masculine and feminine rhymes might, in the speaking of the poem, be marked by the addition of a semivowel in the feminine form /luw/.

Let me begin my foray into the complicities of the octosyllable and translation with a version of 'Le Poulpe', 'The Octopus':

$\begin{array}{ll}\text { Jetant son encre vers les cieux, } & 4>4 \\ \text { Suçant le sang de ce qu'il aime } & 4>4 \\ \text { Et le trouvant délicieux, } & 4>4 \\ \text { Ce monstre inhumain, c'est moi-même. }{ }^{13} & 2>3>3\end{array}$

$\begin{array}{lll}4>4 & \text { Squirting its ink towards the sky, } & / \mathrm{x} \mathrm{x} / \mathrm{x} / \mathrm{x} / \\ 4>5 ! & \text { Sucking the blood of its bride-to-be } & / \mathrm{x} \mathrm{x} / \mathrm{x} \mathrm{x} / \mathrm{x} / ! \\ 8 & \text { With eructational delight, } & \mathrm{x} / \mathrm{x} / \mathrm{x} \mathrm{x} \mathrm{x} / \\ 6>2 & \text { This barbarous monster, it's me! } & \mathrm{x} / \mathrm{x} \mathrm{x} / \mathrm{x} \mathrm{x} /\end{array}$

One might say that the standard English octosyllabic reference is iambic tetrameter. But it is an accommodating beast: it will tolerate the disaccentuation of the odd stress; triple, and even quadruple, time introduced momentarily into its duple time, with compensating vocal acceleration; an added feminine ending; line-initial anacrusis; so-called 
inverted first feet. Ironically, the line that here feels most straightforwardly iambic is the third, because, with a little articulatory distortion, we could promote -nal to stress, as we have already done with its initial e-.

I next convert my quatrain into another two-rhyme fixed form, the triolet:

Squirting its ink towards the sky, Sucking the blood of its bride-to-be, Le Rouge et le noir, it's aiming high! Squirting its ink towards the sky. From vampire to writer? Pigs might fly. Alas, this barbarous monster's me, Squirting its ink towards the sky, Sucking the blood of its bride-to-be.

I do this principally to remind us that the conversion of one verse form into another willy nilly discovers in the source text lines, developments of ideas, which hitherto had remained invisible, which might not have been released but for the unforeseen insinuations of new dispositional demands. And this rewriting begins to ask the question: which is the true poem? By virtue of what exactly does the particular form of the source text have a priority? How strictly does one need to observe octosyllabicity in an ostensibly octosyllabic poem? What is it to author a poem, as opposed to authoring what the poem itself seems to make possible? What if the poem is the total poem, that is, the totality of its possible variants and variations, formal and textual, rather than the apparently 'original' text?

But if now I convert the original quatrain into a rhymeless sixain, with the imposed syllabic structure $6 / 5 / 9 / 4 / 5 / 4$, that is to say, into the oxymoron of fixed-form free verse, I will have:

$\begin{array}{lll}6 & \text { Squirting its ink towards } & / \mathrm{xx} / \mathrm{x} / \\ 5 & \text { The sky, sucking the } & \mathrm{x} / \mathrm{x} \mathrm{x} \\ 9 & \text { Blood of its bride-to-be with eruc- } & / \mathrm{x} \mathrm{x} / \mathrm{x} / \mathrm{x} / \mathrm{x} \\ 4 & \text { Tational de- } & / \mathrm{x} \mathrm{x} / \\ 5 & \text { Light, this barbarous } & / \mathrm{x} / \mathrm{x} \mathrm{x} \\ 4 & \text { Monster, it's me! } & / \mathrm{x} \mathrm{x} /\end{array}$

This version introduces new adjustments of pronunciation, new rhythmic groupings, new self-indulgences of the voice. What is strengthened here is the sense of an impulse-giving choriambic $(/ \mathrm{x} \mathrm{x} /)$ leitmotiv ('Squirting its ink', 'Blood of its bride', 'Tational de-', 'Monster, it's me!'). 
The fourth line assumes a promotion to stress of the first syllable of 'delight', immediately followed by the normal stress on its second syllable, creating a spondaic rather than iambic shape: /'di:'lart/ rather than /d'lart/. And on a second reading one might expect the opening e of 'eruc-', in anticipation of the /di:/ of 'delight', to attract even more stress to itself. At all events, the phrase 'with eructational delight' is now archly infused with enunciatory melodrama and expressive hyperbole.

Before offering my final version of 'Le Poulpe', which is designed to extend our sensory relationship with the cephalopod by resorting to visual languages, I would like briefly to consider Dufy's illustrations, as, indeed, those of Sutherland, and their implications for a distinction between synaesthesia and intersemiosis. While the octosyllable acts to install the vocative and the presence of voice, Dufy's images are forces for accusativity; they are not exactly hors texte, but they are separate and framed, and there is little, I think, to be gained from trying to imagine them as 'portraits', with all that that suggests of increased vocativity. What interests me here are the different degrees of assimilation of the subjects into their landscape. Not surprisingly, the small animals fare best: 'Le Lapin', 'La Souris' and 'La Sauterelle' strike us as being intimately embedded in their environments. Then there are other landscape settings from which the subjects are relatively detached, for example 'La Chèvre du Thibet', 'Le Chat', 'Le Dauphin', 'La Carpe'. In other instances, a natural environment is more cursorily referred to - for example 'La Puce', 'LÉcrevisse', 'Le Hibou', 'Ibis' - and the vegetation strikes one more as decorative motif than as inhabited milieu. Sometimes the environment is occupied by symbolic or metonymic attributes, as in 'Orphée (1)', 'Le Lion"14, 'Le Lièvre', 'La Colombe', 'Le Bœuf', 'Le Serpent'. Although Dufy engineers relational variations (between subject and setting) across his engravings, the separation of these last from the texts inevitably implies a dialogue between juxtaposed arts/media, with the underlying supposition that each art/medium tends towards its own epitomisation. But, because, in my own version of things, the different media should be the expanding constructions of a single mind, that of the translator, what we really want is a closer, developmental interactivity, a sense of the continuities, the co-terminousness, of different sensory experiences, the sense of the ongoing morphing of medium into medium, a synaesthetic as opposed to an intersemiotic approach. 'Intersemiotic' is the term used by Jakobson to describe an interpretation of verbal signs by non-verbal sign systems; ${ }^{15}$ we usually understand the term as a designation of any translation of one art/ medium into another. It is this conceptual relationship between the 
synaesthetic and the intersemiotic that I wish to pursue, below, in my brief comments on my own illustrations.

What Sutherland's true place is in the clash of intersemiosis and synaesthesia is much harder to assess. In his brief preface to the Marlborough gallery's catalogue, ${ }^{16}$ dated 'Menton, $14-X-79$ ', he calls his images illustrations, but complains that their execution makes him feel that he is a prisoner of the text. Giulio Carlo Argan, who provides a short introductory essay in the same catalogue, is of the view that Sutherland's art is visionary and that 'Visionary art is not representational; it cannot, therefore, be illustrative. As comments on Apollinaire's verse, Sutherland's engravings are no more than vague assonances, just as the verses are no more than brief captions to the images.' Sutherland's relationship with the poems was made volatile by the fluctuations in their fertilising capacity; he writes, 'I have not attempted to accompany all the poems, some of which, for various reasons, I could make nothing of at all. And, I have added one or two images that have no direct reference to the poems, but which refer perhaps, to the difficulties of life and living.' Sutherland, then, uses Apollinaire as a seed bed for images which derive from the poems, both directly and indirectly, but which explore their own pictorial preoccupations. It is as if the relationship has become a dialectical one: Apollinaire generates Sutherland for whom Apollinaire provides a kind of commentary. What may have begun as an intersemiotic project has, certainly in the 17 aquatints, drifted into the silent kingdom of Sutherland's own preoccupations. But the 19 black-and-white (sepia) images with which the catalogue's texts, and principally the translations from Le Bestiaire by Jean Wood, are decorated, suggest a more intimate and involuntary relationship. These are not adaptations of text to another art or medium in such a way that the new art/medium can, interpretatively, suggestively, challengingly, interact with the original text. They are more synaesthetic in nature, as if triggered by more anarchic impulses, outcrops of text travelling through different sensory modalities, with a greater sense of ongoing perceptual participation, and of the tireless interferences of the unconscious that characterise graphic doodling. They generate an inter-sensory crosswiring that relates the act of reading to a mechanism of self-proliferation (intersensory, intertextual, cross-linguistic, associative) in the reader. These are the energies explored in my final translation of 'Le Poulpe' (illustration 24). Here, the flickering play of the Gershwin song, of the strangely appropriate word from another language, produced by the phonetic transcription ('pulp'), the unsolved mystery of the bilateral development of poulpe and pieuvre (both from Latin polypus > polype), 


$\begin{array}{lll}6 & \text { Squirting its ink towards } & / \mathrm{x} \mathrm{x} / \mathrm{x} / \\ 5 & \text { The sky, sucking the } & \mathrm{x} / / \mathrm{x} \mathrm{x} \\ 9 & \text { Blood of its bride-to-be with } \mathrm{eruc}-\mathrm{x} \mathrm{x} / \mathrm{x} / \mathrm{x} / \mathrm{x} \\ 4 & \text { Tational de- } & / \mathrm{x} \mathrm{x} / \\ 5 & \text { Light, this barbarous } & / \mathrm{x} / \mathrm{x} \mathrm{x} \\ 4 & \text { Monster, it's me! } & / \mathrm{x} \mathrm{x} /\end{array}$

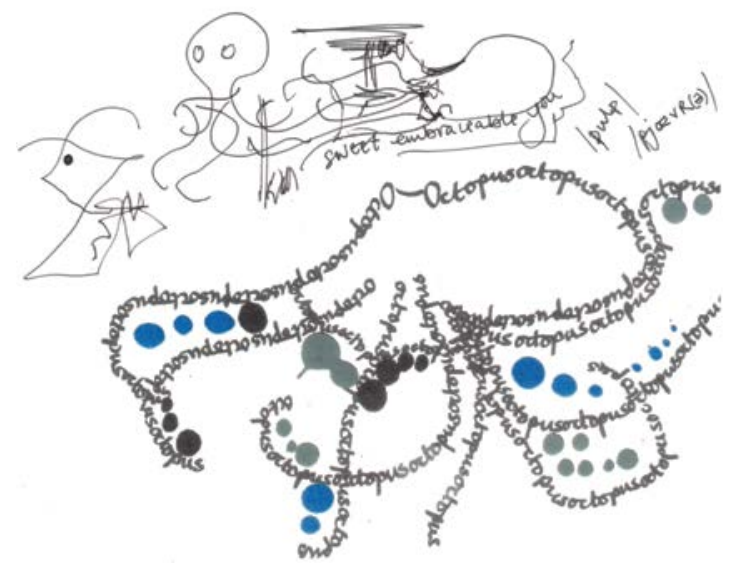

Illustration 24 Clive Scott, graphic 1: 'The Octopus', with handwritten outline, doodling and enamel paint

the calligraphically written outline, the enamel-paint dots, the doodling with fish faces and tentacular entanglements - all this is only the beginning of a non-finite process of ramification and relating, of pure graphism modulating into writing and image and back again.

Our rather Oulipian intention, then, in translating 'Le Poulpe', is to create a new kind of fixed-form free verse, in which accentuation is not so much made freer as redistributed, interrogated, re-sensitised. The metabolisms of different verse lines and verse forms cover the different ways in which verse lines and verse forms process language, in acts of transformative body chemistry: clearly, the same 'raw' language would not produce the same style of expressivity in stichic alexandrines as it would in an octosyllabic quatrain or in free verse. Put another way, if a particular verse form is the instrument - the piano, say, on which the language is played - then the new forms that translation, whether intralinguistic or interlinguistic, might introduce are like John Cage's prepared pianos, producing sounds not available to the original piano, a process akin to using forms, graphics, images, as prostheses. And 
translation further complicates these relationships by introducing another dimension of metabolic processing, namely other languages that is, other national languages and the languages of other media. But if it is the task of translation to search out the expressive latencies and invisibilities of the source text, then metabolic change is an inevitable device of their uncovering.

My next study of translation as the agent of a poem's and animal's innate compulsion to self-transformation is 'Ibis'. This choice is no accident, since the Egyptians give us the firmest basis for a zoopoetics that has transformative and assimilative processes at its heart. In the ancient Egyptian world, not only are animals identified with gods, and vice-versa, by virtue of shared qualities and behaviours, and become themselves sacred while remaining supremely ordinary, but in their mummified forms they also intercede for the human with the gods. There is, therefore, a free reciprocal flow between the human, the animal and the divine, of which the animal seems to be the principal engineer, the vital motor of exchange. And the fact that gods might be represented by more than one animal - as Thoth is by both ibis and baboon - suggests that the animal world is itself a fine weave of diacritical but interdependent differentiations, akin to a language system in the Saussurean image. But animals are neither signs nor coded units; their world is a shifting play of relative values, imperfective, progressive, ongoing, a nexus of changing metaphors and metonymies, being made and remade.

If we speak of animals in these grammatical terms of verb aspect (imperfective, progressive), then we should also say that ancient Egyptian artists and artisans treat them 'aspectively'; 'aspectivity', Hélène Guichard tells us, is 'le fait de représenter simultanément les aspects significatifs d'un même sujet selon une multiplicité de points de vue'17 ('the simultaneous representation of the significant aspects of a single subject according to a multiplicity of points of view') an ancient version, then, of the perceptual habits of cubism. Guichard goes on to account for the bright blue hippopotamus figurines in earthenware, dating back to the Middle Kingdom dynasties (20551650 BCE), decorated with plants and fish, as follows: 'L'explication est simple: le point de vue est celui de l'artiste égyptien, habile observateur de son environnement, qui voit au travers des eaux bleutées du Nil l'amphibien se frayer un passage dans la végétation et la faune aquatiques"18 (The explanation is simple: the point of view is that of the Egyptian artist, practised observer of his environment, who, through the blue waters of the Nile, sees the amphibian making its effortful way through the aquatic vegetation and fauna'). The overpainting of the 
animal with blue, and with plants and fish, is a measure of how deeply immersed in its environment the animal is; and it is this participatory embeddedness that aspectivity tries to capture.

But given what we have claimed, we should be wary of using the word 'metaphor' of these kinships and homologies. It seems perfectly justified to say that Apollinaire, in many instances, uses animal behaviour as metaphors of his own condition; ${ }^{19}$ but to do so is, ironically, to endorse notions of fixed identity, and to make the device rhetorical, a mere figure of speech. It is this notion of metaphor that turns the octosyllabic quatrain into a zoo, because identity pursues a policy of non-dynamic difference and consistency to self, and because the designation of events in language as figures of speech condemns them to concept, to an existence as nomenclature and stylistic 'effect'. Our view invests in the ongoing dynamism of metamorphosis and the multiplication of points at which elements in the world make contact with each other, diversify their ways of relating, change their positions relative to each other. In this view, metaphor is not a figure of speech, expressly called upon to 'image' a coincidence of phenomena; it is rather the shape language takes as it actualises moments of metamorphic intertwining.

Just before we proceed to 'Ibis', there is another strand of thinking to set beside the Egyptian. Recent work in the phenomenology of the animal kingdom has alerted us to ways in which we need to embrace more holistic and flexible responses to animal behaviour, in its interactions with human behaviour, ${ }^{20}$ and to reconcile perspectives on the species with those on the singular animal. We need more boldly to confront the mysteries of animal subjectivity, intersubjectivity and agency, and the meaning of territory in terms of 'dynamic, relational inhabitation'. ${ }^{21}$ The notion of verse forms themselves as territories, able in their multiplicity to activate different rationalities or mindsets, is hugely suggestive for both translation and zoopoetics if we assume that these latter are concerned with the diversification of fields of vision or cognitive schemas: territories, like Jakob von Uexküll's Umwelten, are spaces generating different patterns of attention, different rhythms of behaviour, different modes of being. And in multiplying translations, the translator and zoopoet are ensuring that Umwelten overlap and are in communication with each other. The verse forms explored by translation are, therefore, also territories in the sense of ethological spaces, and spaces of particular rhythms of being and consciousness:

Our daily life is measured by multiple rhythms. These are faster or slower for other species. The body itself has its rhythms. Rhythms 
are also a way of acting on the world: the rhythm of a repetitive refrain soothes, creates order and gives access to a certain degree of autonomy. ${ }^{22}$

The changing rhythms of 'Ibis' run as follows:

Oui, j'irai dans l'ombre terreuse

O mort certaine, ainsi soit-il!

Latin mortel, parole affreuse,

Ibis, oiseau des bords du Nil. ${ }^{23}$

$$
\begin{aligned}
& 3>2>3 \\
& 4>4 \\
& 4>4 \\
& 2>2>4
\end{aligned}
$$

and then, in a 'standard' translation, as:

$\begin{array}{ll}\text { Down into earthy shadows I'll } & / \mathrm{x} x / \mathrm{x} / \mathrm{x} / \\ \text { Go. Death's certain, yes, sic fiat, } & / / / \mathrm{x} / / / \mathrm{x} \\ \text { Fatal Latin, dreadful diktat, } & / \mathrm{x} / \mathrm{x} / \mathrm{x} / \mathrm{x} \\ \text { Ibis, bird of Thoth, bird of the Nile. } & / \mathrm{x} / \mathrm{x} / / \mathrm{x} \mathrm{x} /\end{array}$

and then, in an 'Octopus' sixain, as:

6 down into earthy sha-

$/ \mathrm{xx} / \mathrm{x} /$

5 dows I'll go. Death's cer$\mathrm{xx} / / /$

9 tain, yes, sic fiat, fatal Latin,

$\mathrm{x} / / / \mathrm{x} / \mathrm{x} / \mathrm{x}$

4 dreadful diktat, $/ \mathrm{x} / \mathrm{x}$

5 ibis, bird of Thoth,

$/ \mathrm{x} / \mathrm{x} /$

4 bird of the Nile.

$/ \mathrm{xx} /$

and then, in a semi-calligrammatic 'Ibis' nonet 3/2/5/4/4/4/5/4/2, depicting a seated ibis, as:

$\begin{array}{cll} & \text { down } & / \\ & \text { into } & / \mathrm{x} \\ & \text { earthy } & / \mathrm{x} \\ \text { shadows I'll go. } & \text { Death's } & / \mathrm{xx} / \\ \text { certain, } & \text { yes, sic } & / \mathrm{x} / / \\ \text { fiat, } & \text { fatal } & / \mathrm{x} / \mathrm{x} \\ \text { Latin, } & \text { dreadful } & / \mathrm{x} / \mathrm{x} \\ \text { diktat, } & \text { ibis, bird } & / \mathrm{x} / \mathrm{x} / \\ \text { of Thoth, } & \text { bird of } & \mathrm{x} / \mathrm{x} \\ & & \mathrm{x} /\end{array}$




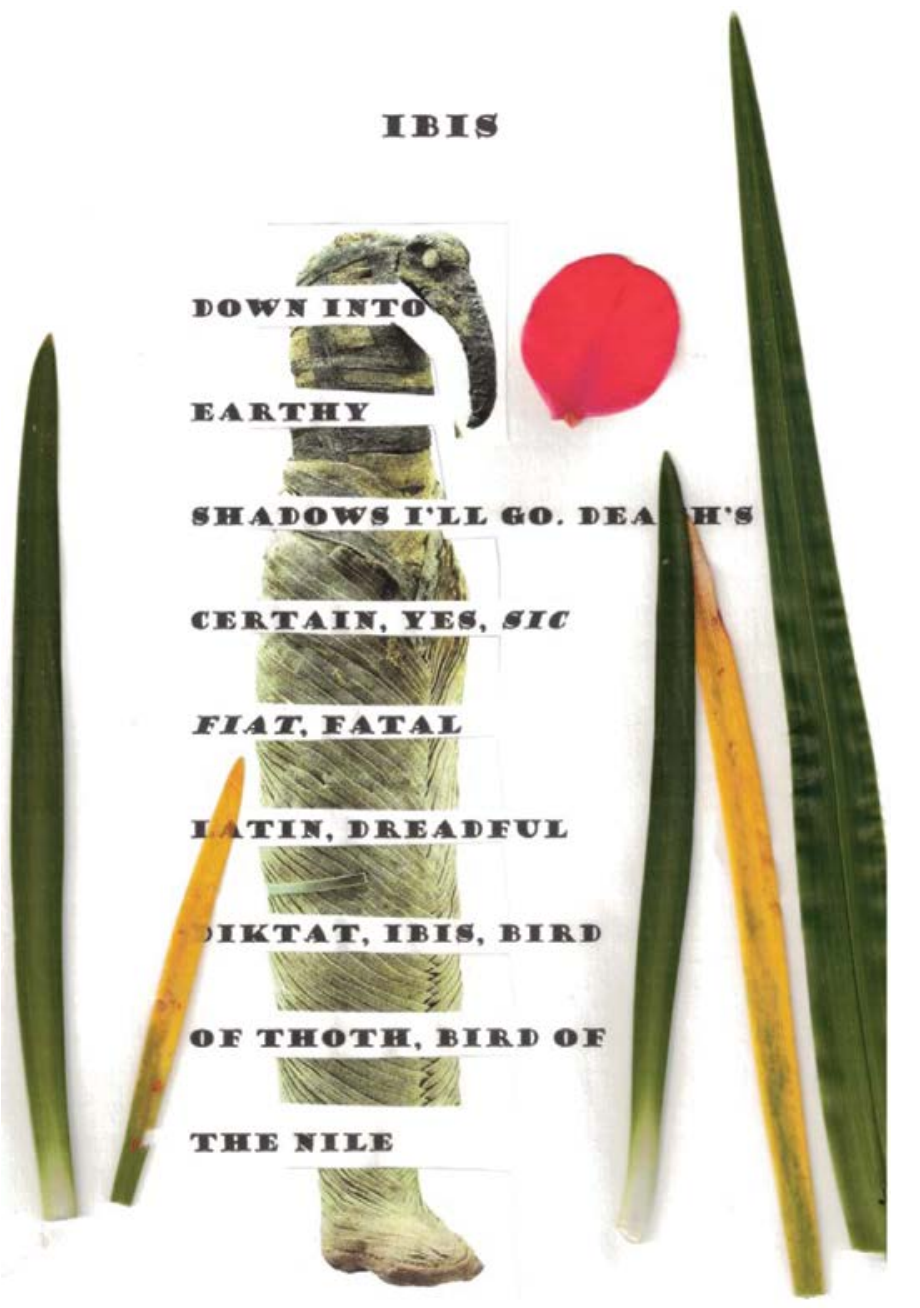

Illustration 25 Clive Scott, graphic 2: 'Ibis', with petal and leaves, sectioned photograph and Goudy Stout typeface

Finally, again as a nonet, with my 'Egyptian' typeface (Goudy Stout) and an image of a mummified ibis, 'Ibis' makes its own foray into antiidentitarian synaesthesia (illustration 25). Identity is what intersemiosis attributes to the conduct of the different arts. And scruples about identity are what make us anxious to do justice to the otherness of the animal world, to fight shy of the anthropomorphic and the anthropocentric. But the world of synaesthesia is a world of intersensory morphings and modulations, which keeps the subject on the move, 
unfixable, constantly self-enriching. Here, for example, I combine a collaged, fragmented photographic image with scanned realia: a camellia petal, and leaves from a garden shrub. In such circumstances, flexible and changing relationships make questions of identity otiose and paralysing, and mark anthropomorphism as only one in a whole range of postures and positions whose very multiplicity nullifies its power to colonise or condescend.

What all this amounts to in terms of a (translational) poetics is this: rhythm is significant as the paralinguistic totality of the voice speaking verse, and rhythm is significant in its own unfoldingness, that is as the adventure and shape of ongoing perception and consciousness in language. We translate into rhythm, in order to write, not the meaning, but our readerly experience of the source text. If, then, expressivity matters more than meaning, if verse forms exercise the possibilities of expressivity, then it must be added that this expressivity is not to be found in tropes, or in an affective lexicon, but in articulation, in vocal manipulations of language, in auditory selection, in experimental performance, in visual languages. Language is given sense as it unfolds; sense-making is not a recuperative activity, but an inaugurative one. And let us remember, too, Pierre Guiraud's words: 'Au plan prédicatif, les mots sont des signes, au plan locutif des actes' ${ }^{24}$ ('On the predicative level, words are signs, on the locutional level, acts').

If the translator is to drive forward this ever-renewed mutability of the animal's place in the world and of its relations with the human and the otherworldly, he or she must be ready not only to undertake those re-metabolisations of the subject that we explore through formal reconfigurations, but also and quite simply to write other versions, both in the same form and in new forms, to show how the animal is for ever on the brink of its own diversity, depending on what a new set of rhymes or linear dispositions want to bring forth. I take just one example, 'La Carpe', 'The Carp':

Dans vos viviers, dans vos étangs, $\quad 4>4$

Carpes, que vous vivez longtemps! 2' $>6 / 2$ ' $>4>2$

Est-ce que la mort vous oublie, $\quad 5>3$

Poissons de la mélancolie. ${ }^{25} \quad 2>6$

Whether in fish-tanks or in ponds, Carp, aquatic Methuselahs, Death to your call no more responds, But then, you're hardly revellers. 
Have you done carping, Carep? In ponds

Your disputertious spirit pains

Me. Were you once to hear an ONDES

MARTENOT, might you then refrain?

Carpe,
carp, crap,
parc, no JarDIN
des Tuileries, greed
jostling WITH greed.
Uncle Guillaume
reckons DEATH
's forgotten you,
gloomy pois
SONS.
These
distant rhymes
make a passable
fish-tail soup

The 'standard' translation from which I start out already resets the relationship between the fish and death, making the fish rather than death the prime mover, and expressing the melancholy in a negative rather than positive construction. My own take on the carp begins not in Versailles, as Dufy's does, but in the Jardin des Tuileries, not mentioned in the quatrain, but the locus of the disputatious spirit in the competition for tasty morsels. Here I begin that exploration of the ways in which the word 'carp', in all its metamorphic forms, deeply inhabits our lexicon. The shifts in typeface are designed to highlight other characteristics: Wide Latin tells something of 'carp's' etymological origins and character $(\mathrm{OF}<$ Low Latin < a Visigoth word; wide = slang, unscrupulous, as in 'wide boy'); 'disputatious' is in Snap ITC, for obvious reasons; and the Algerian typeface of 'ondes Martenot', a so-called billboard or poster face, is designed to be as eye-catching as the early electronic instrument is ear-catching, but with a suggestion of the vulgarly showy and the already dated. My calligrammatic version, which picks out, in capitals, the abba scheme of half rhymes (themselves setting an English graphic 'din' against a French nasal 'sons'), continues to explore the lexical manifestations of 'carp' in Latin and anagrammatic forms. Our language, we discover, is itself a menagerie, alive with animal activity, with zoological metamorphosis, with games of concealment. 
And, finally, a last comment on the synaesthetic. In illustration 26, the poem on the carp has not only generated an illustration styled like that of the octopus, but its space has been invaded by realia - three postcards to be exact, showing, from the left: (i) a label from the Norwegian Canning Museum in Stavanger, bearing an image of King Oscar II of Sweden and Norway; (ii) herring being packed in barrels in Great Yarmouth in the 1930s; and (iii) a stamp from Morocco depicting Sciaena umbra (brown meagre or corb), of the croaker family, to be found in the Mediterranean and Black Sea. The carp joins another menagerie. The circumambient
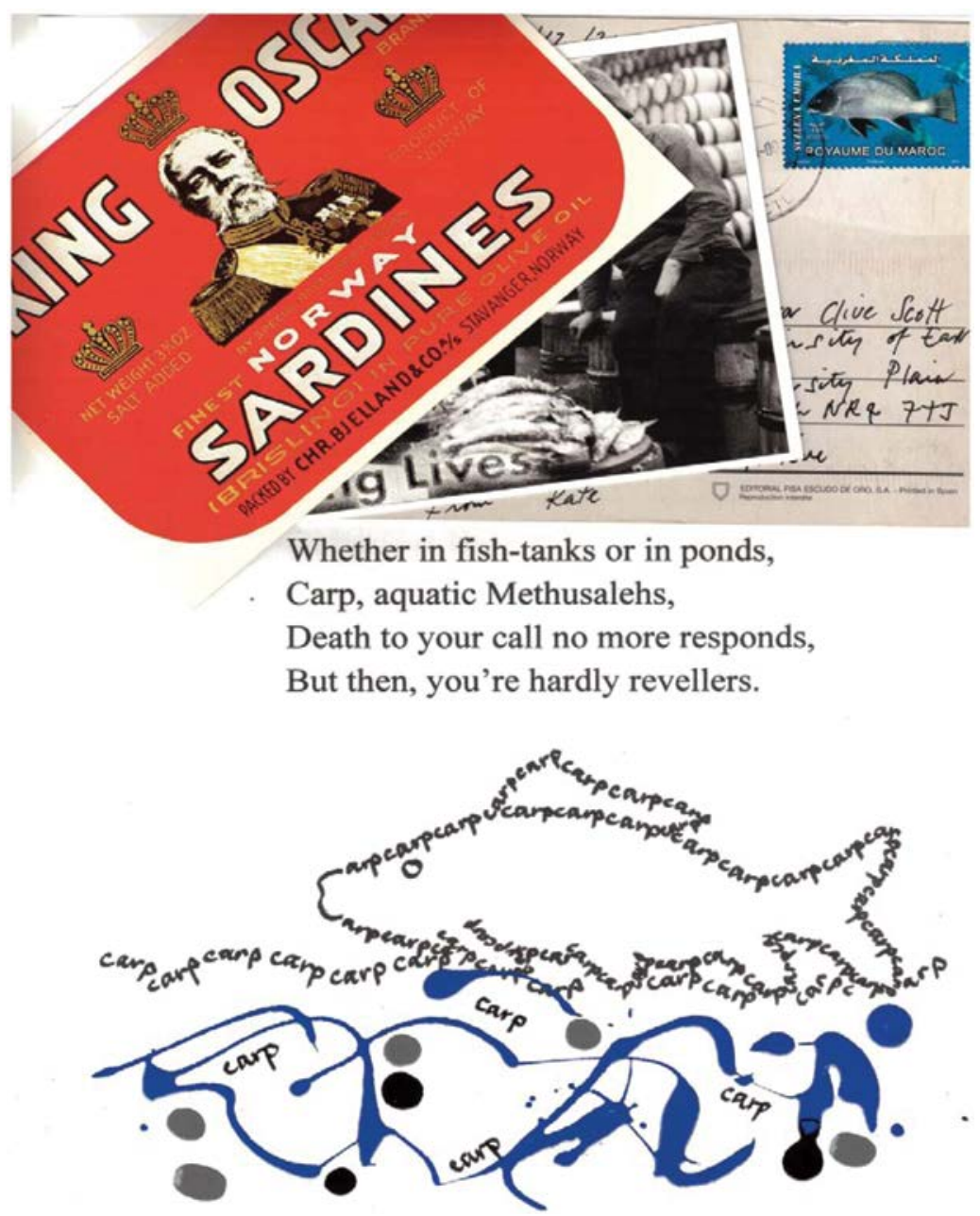

Illustration 26 Clive Scott, graphic 3: 'The Carp', with postcards, handwritten outline and enamel paint 
world surrounds us not only with multiplying points of view, but with the sensory experience connected with them, and realia are likely to activate senses - smell, touch, taste - less immediately summoned by pure text. We translate with the world as much as into the world; reading and translation are fully ecological activities. If we believe that a zoopoetics will thrive on aspectivity, and that translation peculiarly fosters aspectivity through its pursuit of what we have called re-metabolisations, then synaesthesia, rather than intersemiosis, contributes directly to that same end: it encourages us to turn the animal subject through a set of perceptual and relational variations such that our own body is bound into those variations. And, in speaking of the body, we must always remember its situatedness, in the circumstances and environment of reading. The reader's body, rather than linguistic referentiality, is the essential conduit between the source text and the real world. This is a zoopoetics of selfmultiplying heterogeneous relationship, in which text, by virtue of the translational act, is the agent of tireless perspectival reinvention.

\section{Notes}

1 We should also remember what Apollinaire (1965, page 33) further writes in his note on this poem: 'Et quand la lumière s'exprime pleinement tout se colore. La peinture est proprement un langage lumineux' ('And when light is fully able to express itself, everything becomes coloured. Painting is quite literally a luminous language'). As Timothy Mathews suggests, it is as if Apollinaire were looking forward, beyond Dufy, to the Orphism of Robert Delaunay (Mathews 1987, 234n24).

2 Apollinaire 1965, 34.

3 Unless otherwise indicated, all translations are my own.

Apollinaire 1965, 27.

Apollinaire 1965, 26.

See Deleuze and Guattari 1980, 185-204.

Gautier 1859, 352.

8 Although Milner and Regnault (1987) examine these different degrees in relation to the mute e, liaison and accent, they do so in order to identify their different linguistic contexts and thus to promote the idea that decisions about them are linguistically rule governed rather than improvised in response to expressive considerations.

9 Deleuze and Guattari 1980, 93-113.

10 Boulez 2011, 95-6.

11 Apollinaire 1965, 30.

12 Milner and Regnault 1987, 36.

13 Apollinaire 1965, 22.

14 Bohn 2004 identifies a Venetian background in 'Le Lion' corresponding to the animal's being the symbol of Saint Mark as well as of Christ (pages 49-50). He also discovers a Versailles setting for 'La Carpe': the Escaliers des Cent-Marches, the ornamental pond known as the Pièce d'Eau des Suisses and the equestrian statue of Louis XIV by Bernini (pages 50-1).

15 Jakobson 1992, 145.

16 Sutherland 1979.

17 Guichard 2014, 13.

18 Guichard 2014, 13. 
19 Even though John Berger is happy to use the word 'metaphor' of the human/animal connection as he pursues examples in Homer's Iliad (Berger 2009, 16-21), he does qualify his use by observing 'Within that relation what the two terms - man and animal - shared in common revealed what differentiated them' (16) and 'Everywhere animals offered explanations, or, more precisely, lent their name or character to a quality, which like all qualities was, in its essence, mysterious' (18). Metaphor then, in Berger's mind, is more an interrogative figure, a figure designed more to insist on the difficulty of penetration, than display the analogically unproblematic.

20 See, for example, San Martín and Pintos Peñaranda 2001.

21 Lestel, Bussolini and Chrulew 2014, 143.

22 Herzfeld and Lestel 2005, 637.

23 Apollinaire 1965, 31.

24 Guiraud 1970, 54.

25 Apollinaire 1965, 25.

\section{Bibliography}

Apollinaire, G. 1965. OEuvres poétiques, edited by Marcel Adéma and Michel Décaudin. Paris: Gallimard.

Berger, J. 2009. 'Why Look at Animals', in Why Look at Animals?, 12-37. London: Penguin.

Bohn, W. 2004. 'Contemplating Apollinaire's Bestiaire', Modern Language Review, 99/1: 45-51.

Boulez, P. 2011 (first published in 1963). Penser la Musique Aujourd'hui. Paris: Gallimard (Denoël/ Gonthier).

Deleuze, G. and Guattari, F. 1980. Mille Plateaux: Capitalisme et schizophrénie 2. Paris: Minuit.

Gautier, T. 1859 (first published in 1844). Les Grotesques. Paris: Lévy.

Guichard, H. 2014. 'La Métaphore animalière pour penser le monde', L'Objet d'Art: Hors-Série Exposition (Des animaux et des pharaons), 85: 10-19.

Guiraud, P. 1970. La Versification. Paris: PUF.

Herzfeld, C. and Lestel, D. 2005. 'Knot tying in great apes: Etho-ethnology of an unusual tool behavior', Social Science Information 44/4: 621-53.

Jakobson, R. 1992 (first published in 1959). 'On linguistic aspects of translation'. In Theories of Translation: An anthology of essays from Dryden to Derrida, edited by R. Schulte and J. Biguenet, 144-51. Chicago: University of Chicago Press.

Lestel, D., Bussolini, J. and Chrulew, M. 2014. 'The phenomenology of animal life', Environmental Humanities 5: 125-48.

Mathews, T. 1987. Reading Apollinaire: Theories of Poetic Language. Manchester: Manchester University Press.

Milner, J.-C. and Regnault, F. 1987. Dire le Vers: Court traité à l'intention des acteurs et des amateurs d'alexandrins. Paris: Seuil.

San Martín, J. and Pintos Peñaranda, M. L. 2001. 'Animal life and phenomenology', in The Reach of Reflection: Issues for phenomenology's second century, edited by S. Crowell, L. Embree and S.J. Julian, 342-63. Boca Raton: Center for Advanced Research in Phenomenology.

Sutherland, G. 1979. Apollinaire, Le Bestiaire ou Cortège d'Orphée. London: Marlborough Fine Art Ltd. 


\title{
5
}

\section{Animals on Parade: Collecting sounds for I'histoire naturelle of modern music}

Rachel Mundy

\begin{abstract}
A
I'Âne

'Hee-haw!' (Please say that out loud as you read it.) Given the bestial nature of this collection, I thought it would be acceptable to begin by making an ass of myself. Instead of following the precepts of Aristotle, in this essay I ruminate on the festival animals of French modern music, processing through a parade of alphabetical topics that begin with the medieval Festival of the Ass and roam into the twentiethcentury music of 'Les Six' and their milieu, where the ass returns in the contexts of the festival, the fair and the circus. I start, then, with l'âne - the ass.

Sources in the late nineteenth and early twentieth centuries describe the Festival of the Ass as occurring every year during the Middle Ages in the south of France, ostensibly in order to celebrate the Holy Family's flight to Egypt. ${ }^{1}$ Descriptions of the festival's procedure vary, but many describe a pretty girl riding a donkey to or from church while the local priest said 'Hee-haw, hee-haw, hee-haw' instead of 'Go in peace'. Participants at the festival were said to bray loudly in church before singing the 'Prose de l'âne', a carol sometimes named 'Orientis partibus' for its first line. The melody is still familiar today as the Christmas carol 'The friendly beasts'. Here is a loose translation of the text of the medieval carol's opening Latin verse:
\end{abstract}


Orientis partibus,

Adventavit asinus,

Pulcher et fortissimus,

Sarcinis aptissimus.

Hez, sire Anes, Hez!

Here comes the ass,

From eastern parts.

He's handsome and so strongly built

That heavy loads are just his tilt.

Gee-up, sir ass, Gee-up!

In 1938, composer Arthur Honegger used the carol in his oratorio Jeanne d'Arc au bûcher, set to words by Paul Claudel. In Honegger's version, the court reporter at Joan's trial is a literal ass, entering the courtroom with loud hee-hawing and laughter. He is one of a procession of animals involved in the trial, including a sheep, tiger, fox, lion and snake. Each animal is introduced briefly to the audience with a short musical parody, creating a kind of musical procession in which stylistic caricatures set each animal apart. For example, the pig, who plays the role of judge (a pun on Pierre Cauchon, who led the trial of Joan of Arc), enters the courtroom accompanied by a loud music-hall number, singing 'I'm a pig! Me, meeeeee, I'm a pig!' while the chorus chants 'Porcus! Porcus! Porcus! Porcus!'

When Honegger's ass enters the courtroom, he receives a particularly elaborate tribute to animal musicality. His hee-hawing melody unfolds as part of a three-part fugue sung by the chorus, set to a vaudeville-inspired remake of the French version of the carol 'Hail sir donkey ...', while the original Latin tune (the source of the fugue melody) is sung in the bass as a cantus firmus. The end of each line in the French fugue shifts from melody to mimicry, with the chorus singing 'hee-haw' in imitation of a donkey's loud bray amid a laughing 'ha ha ha ha ha'.

For those not in the know, this passage is recognisable to the educated European ear as a musical parody in its own right. Honegger's listeners would have heard in the braying 'hee-haw!' echoes of Bach and Schütz, of the fugues and flights of fancy that were a trademark of German counterpoint at the end of the seventeenth century. Every student at the Paris Conservatoire - where Honegger spent seven years knew this antiquated German sound-world through required composition exams, dutiful piano exercises, annual courses in counterpoint, and 
endless other examples of copying, practising and imitating Bach's example. Deemed a high point in classical music's origins, this was a style that teachers at the Conservatoire believed originated not in Germany, of course, but in France, in the form of medieval songs like the 'Prose de l'âne.' ${ }^{2}$ Honegger would have learned to love this music at school, and perhaps, loved to hate it.

This parade of animals from Jeanne d'Arc has always fascinated me. I love how funny it is, and I love the animals. At face value, the ass's passage seems to be a sharp rebuke to a host of things a listener might imagine were distasteful to Honegger: self-important scholars, vaudeville, German counterpoint and rote conservatory exercises. One can imagine (and I hope someone will write) a historical study of the implicit criticisms of this work. These are criticisms that matter in the work's reception history, for although Honegger completed the oratorio in 1938, it was one of the most popular works to be publically performed in France during World War II. ${ }^{3}$ Played repeatedly in Vichy France under the aegis of an anti-English national identity, surely this asinine German chorale was a salve to listeners forced to hear a steady stream of Bach, Beethoven and Wagner during the war. ${ }^{4}$

But though the passage makes fun of these other Others, it also offers a charming, memorable and strange exoticism. The complexity of the interwoven parts is striking, and so is the 'hee-HAW!' that concludes every line of verse with a descending octave. What else, besides satire, is going on in this odd little collection of ass, sheep, tiger, lion and pig? How is the project of collecting beasts, feasts and festivals part of the ongoing court of modernity? How do these things fit into Honegger's world? And what does his ass, and the animals with whom it circulated, tell us about the ways we may still hear animals and other Others?

B

\section{Le Bestiaire}

I leave the ass behind to pursue the bestiary of modern music, a short summary of some of the animals that Honegger's contemporaries wrote into music. Honegger was a member of the musical circle dubbed 'Les Six' by music critic Henri Collet in 1920. Nominally consisting of the composers Arthur Honegger, Darius Milhaud, Georges Auric, Germaine Tailleferre, Louis Durey and Francis Poulenc, the group's social membership was more expansive, including composers, artists and 
writers such as Erik Satie, Pablo Picasso and Jean Cocteau. During the interwar period, they met at each other's homes and at local bars in Montparnasse and Montmartre. Theirs was an artistry of queer masculinity, cultured simplicity and stylistic mixing. ${ }^{5}$ Rejecting the perceived sentimentality of concert music from the turn of the century, they turned to the poets and artists of their own time, notably Jean Cocteau, Paul Claudel and Guillaume Apollinaire.

Members of Les Six rendered quite a few animals in music. Two years after Honegger's courtroom of animals in Jeanne d'Arc, Francis Poulenc created a setting for voice and piano of Jean de Brunhoff's L'histoire de Babar, le petit éléphant. Germaine Tailleferre, the group's only woman, created the music for a 1952 radio broadcast of Erich Kästner's story The Animals' Conference, in which nonhuman animals take over the world in order to stop war. Less explicit animals paraded through songs like Poulenc's 'The Hedgehog' and the titles of works like Milhaud's Le Bouf sur le toit and Poulenc's 'Les Biches'. And, of course, in 1919, both Francis Poulenc and Louis Durey independently created their own versions of Apollinaire's Le Bestiaire as short song cycles Poulenc's version with only 6 of Apollinaire's animals, and Durey's with 26.

Although these works were written by different composers over a 30-year period, they share some of the structural elements of a festival procession that shaped Honegger's Jeanne d'Arc. Almost all of the works I've mentioned adopt an episodic structure that isolates short musical sections or movements and distinguishes those episodes with an idiomatic rhythm or style. In so doing, these episodic works invite the listener to attend to and compare differences of musical style that can be loosely connected to notions of bodily or cultural difference. This processional form was not specific to musical collections of animals, but reflected a more far-reaching interest in acts of musical collection, comparison and pastiche. Early in the century, French composers turned to simple episodic forms drawn from French baroque precedents, such as François Couperin's keyboard works, in their search for alternatives to the long and complex works of Wagner and Brahms. Debussy's 24 Préludes, the fleeting postcards of Estampes, and Ravel's Ma Mère l'Oye, paraded little works for piano in small collections. Les Six and others built upon this precedent, sometimes framing their works in opposition to the celebrations of musical formality they associated with their elders, but retaining the previous generation's love of episodic collections.

Both Poulenc and Durey's settings of Le Bestiaire are cases of these little parades, providing processions of songs that last at most just over a 
minute and rely on the linear, thin accompaniments of the neoclassical aesthetic (piano for Durey, and Poulenc with a version for flute, clarinet and strings). Both composers use idiomatic shifts in musical style and rhythm to craft a sense of an episodic parade of musical styles and rhythms from song to song. Durey's Tortoise (the shell of Orpheus's lyre), for example, opens with a rolled chord in the piano that emulates the strummed strings of the lyre, while the Horse gallops along in an odd five-beat rhythm.

Let me briefly compare their settings of one of these animals in Le Bestiaire, the goat. Both Durey and Poulenc have made their goats rather flippant and urbane creatures, traipsing through the collections with exotic chords and languid tempi. Durey's Tibetan Goat dances lightly to a triple meter reminiscent of a baroque sarabande, favouring a held note on the downbeat and a little eighth note at the end of the measure. Poulenc's does not dance but prances to alternating eighth notes that process in the exotic and ancient dorian mode. Both Goats initially keep to a restricted and sober melody, one that does not reflect my own limited encounters with goats (illustrations 27 and 28). Their attitude seems to match the text, however, which compares the hairs of the Golden Fleece to the golden hair of a lover: 'Les poils de cette chèvre et même / Ceux d'or pour qui prit tant de peine/ Jason, ne valent rien au prix/ Des

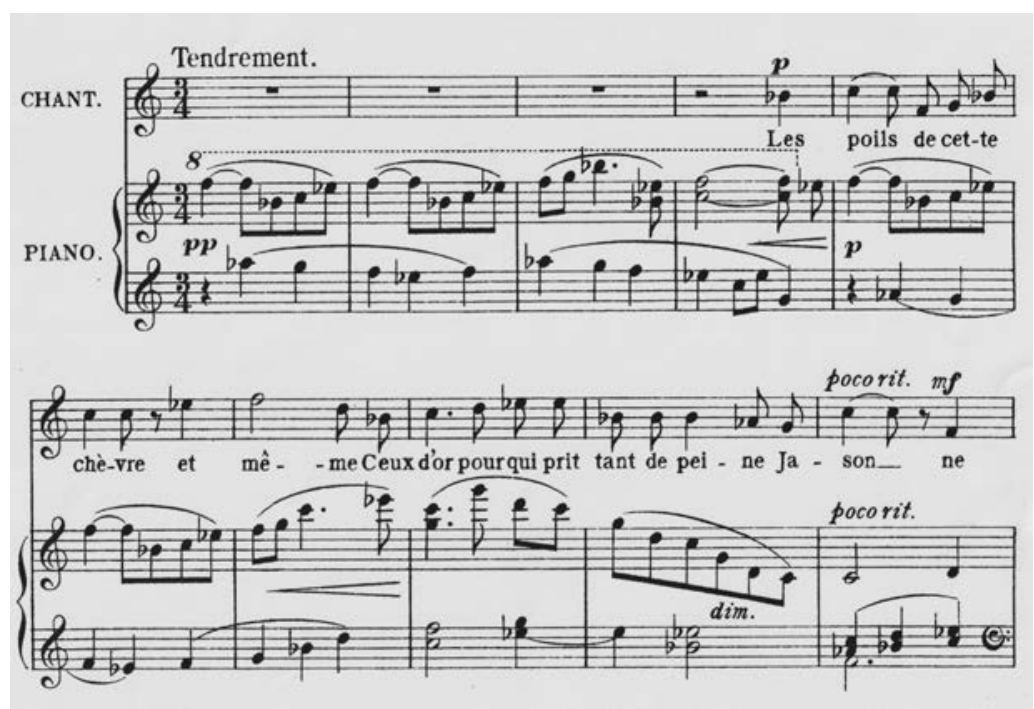

Illustration 27 Music example 1: measures 1-10 of 'La Chèvre du Thibet' from Louis Durey, Le Bestiaire, 6 


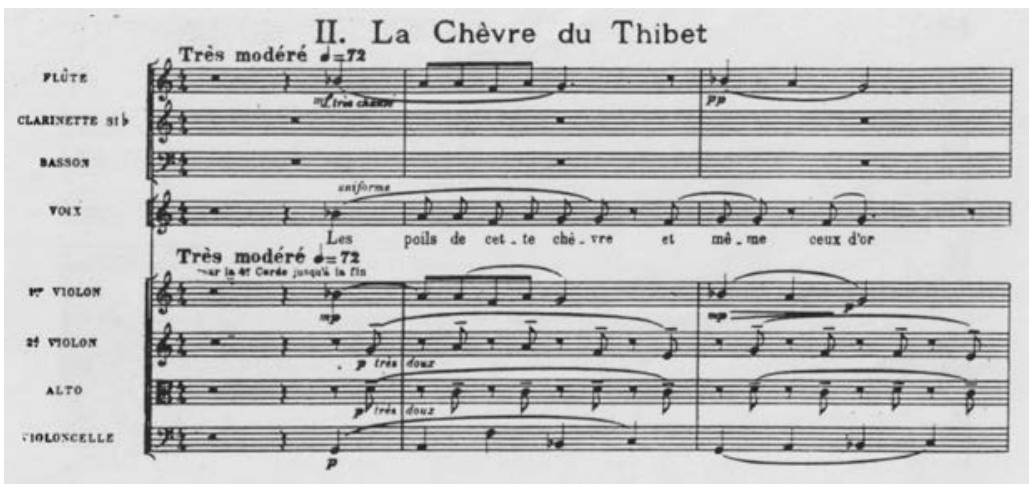

Illustration 28 Music example 2: measures 1-3 of 'La Chèvre du Thibet' from Francis Poulenc, Le Bestiaire, 4

cheveux dont je suis épris'. Listeners can almost enjoy their glimpse of these goats (and the other animals of the bestiaries), hearing the faintly commercialised glimmer of the lovely golden hair without troubling themselves about the poor goat, who was skinned long before the song began. The unfortunate condition of the goat's subjectivity is pleasantly exchanged for the urbanity of the flâneur - at least, until one encounters the title. As other authors in this book have pointed out, Le Bestiaire is compelling in part because its animals are so casually turned into goods: the tortoise into a lyre, the elephant into ivory, the grasshopper into a delicious treat.

These bestiaries of usable animals, however, were set amid good musical company. Maurice Ravel's Histoires naturelles, a song cycle for voice and orchestra, was completed in 1906 and bears an episodic structure and linear harmony that resonates with Durey's and Poulenc's later settings of Apollinaire. Another and more specific backdrop for these collections of animals would have been the posthumous premiere in 1922 of Camille Saint-Saëns' Carnival of the Animals. Originally composed in 1886, Saint-Saëns's Carnival followed a similar episodic logic, with a series of animals processing in a parade of styles. The tortoise, for example, is a not a musical representation of a lyre, but instead is a mockery of Jacques Offenbach's 'Infernal Galop', whose melody is played at an absurdly slow speed. Towards the end of SaintSaëns' collection, the animals are extended to include a section called 'pianists', which mocks the dutiful exercises of a bad piano student and, like Honegger's ass, invites the listener to evaluate human difference in the act of evaluating a musical trope. 


\section{C \\ Cirque}

Supposing at least some of these musical animals to be more than mere allegory, where might Parisian artists and composers have found an actual tortoise or Tibetan goat? In Paris, there were four possibilities: the natural history museum, the zoological gardens, the menageries of street fairs and the circus. The latter two - the fair and the circus - are well-known sites in the landscape of modernism. While scholars often attribute carnivalesque aspects of modernism to visits to the fair or the circus, there is surprisingly little literature that details exactly what those visits entailed, and nothing, as far as I know, that locates modern music's processions of animals in relation to literal experiences of animals in these places.

With that thought in mind, I'm going to take a moment to imagine that trip to the circus, and the animals and music that one encountered there. In 1923, composer Darius Milhaud moved to a new apartment on boulevard de Clichy in Montmartre. In several sources, Milhaud describes weekly meetings at his apartment with members of Les Six and its social circle:

We had developed the habit of dining together every Saturday. In addition to the six musicians (Auric, Durey, Honegger, Poulenc, Germaine Taillferre and me), writers such as Jean Cocteau, Raymond Radiguet, Paul Morand, Lucien Daudet, painters such as PICASSO, Guy-Pierre FAUCONNET, Roger de FRESNAY, Raoul DUFY, Jean HUGO, the singer KOUBITZKY, the pianist Juliette MEROVICH [sic] came to my place before dinner. Paul MORAND made the cocktails. We played the works we had composed in the week. POULENC sang his Cocardes, AURIC had just written his foxtrot: Adieu New York. AURIC and I played the four-hand version of Le Bouf sur le toit. After dinner, which took place in a little restaurant in Montmartre, we went as a group to see the fair or the Médrano circus. The aesthetic of the music-hall was in full vogue and we loved the sketches of the famous Médrano clowns, the three FRATELLINI. ${ }^{6}$

The group would meet for drinks at Milhaud's apartment, go to dinner at a small restaurant on rue Blanche, and then walk up and down boulevard de Clichy, all told a short walk that was usually under a mile start to 
finish. ${ }^{7}$ At the west end of the street, right at the turn to rue Blanche, was the Moulin Rouge cabaret. At the east end, less than half a mile away, was the Cirque Médrano with its orchestra, acrobats, equestrians and lion-tamers. Between the two were cabarets, theatres, cafés and hotels.

For several weeks each year, boulevard de Clichy was also home to the booths, rides and theatres of the Fête foraine de Montmartre, one of Paris's annual carnivals. When the fair was running, walking up and down this street offered a real-world bestiary of sound. In between the fair's rides and shooting galleries, sideshow booths called 'parades' fronted temporary theatres set up on the side of the street, populated by barkers who tried to persuade visitors to pay the entrance fee required to see the acrobats, animals, boxing or other entertainment behind the booth. While the walls of the fair's temporary booths and buildings might restrict a visitor's view, they did little to restrict the flow of sound. As far as the ears were concerned, the enclosed parade bands, rides, animals, games and other attractions were a chaotic mixture. Listeners heard gunshots, shouting, barrel organs, small orchestras, brass bands and the cries of captive performing animals. ${ }^{8}$ During Milhaud's housewarming party in 1923, which doubled as a birthday celebration for Jean Cocteau, the sounds coming through the open windows of his apartment included 'the music from the organ-grinders, the sounds of shooting, and the growls of caged wild animals'. ${ }^{9}$ The same year, one of the reviews in Le Gaulois described much the same soundscape: 'From the illuminations, to the music, to the cries of joy, the songs, the sirens, the sounds of the trumpets, the howls of wild beasts, the sparkling sideshows, and the pressing and jostling of the sizeable crowd: it's the fair of Montmartre. ${ }^{10}$

The street music of these settings was a riotous mixture in its own right. Organ grinders carried small barrel organs with changeable cylinders that played popular tunes from the opera for a fee. ${ }^{11}$ Brass bands and light dance orchestras performed middle-class dances like waltzes and marches in popular theatres, cafés and public squares. ${ }^{12}$ And American jazz bands had recently become popular in cabarets and bars. During the Fête foraine, these sounds would have competed with the sounds of handheld organs and sideshow musicians in the street.

At the end of the block, the Cirque Médrano provided its own soundscape. This was a circus that Degas, Toulouse-Lautrec, Seurat, and later Picasso and Cocteau eagerly watched and mingled with. ${ }^{13}$ One of the many reasons artists loved the Médrano was its band, which was directed by Jean Laporte and was considered one of the best circus orchestras in Europe. The Médrano's band would have had some 
percussion, wind and brass instruments as a bare-bones minimum; some of the Dufy brothers' paintings of the Médrano suggest jazz ensembles, including one image by Jean Dufy of what appear to be performers in blackface. The Médrano's band played older popular dances from the turn of the century, following in the tradition of brass bands that had once been employed by European zoos and pleasure gardens. ${ }^{14}$ Those outdated dance tunes performed by a brass band are the sound we hear today as 'circus music': the polka, march, quadrille and galop. One of the most well-known examples is the 'Entrance of the gladiators', which was recorded by Jean Laporte and the Cirque Médrano's orchestra in $1957 . .^{15}$ The piece is a typical brass-band march of the nineteenth century, with a strong walking rhythm of oneTWO, one-TWO. The recording by the Cirque Médrano orchestra has a remarkable xylophone solo, one that suggests a possible source of inspiration for the new uses of percussion instruments by French composers like Edgard Varèse.

How would a listener of Honegger's day come to associate this riotous soundscape of animals, gunshots and bands with a parade of species difference? I can't even begin to really examine this question in detail, but I'd like to point out that the circus and the fair presented a disorganised assortment of classes and classifications that included differences of musical style as well as differences of social class, gender, sexuality, ethnicity and species biology. Such musical mixings had long garnered animal names, as with the Victorian organ-grinders compared to monkeys in Britain's popular press. ${ }^{16}$ It seems significant that music scholars sometimes used the word 'species' (and in French espèce) to describe both animal species and categories of musical style or musical instruments. ${ }^{17}$ Members of Les Six would have known this use of the word. In a period that often treated difference as a farranging category of bio-cultural comparison, the sounds of the circus and the fair created a setting that fostered questions about hierarchy, power and relationships across boundaries that are still important to Western listeners today.

D

\section{Dompteurs}

In 1929, writing at the end of the Parisian circus's heyday, the Cirque d'Hiver's lion-tamer, or dompteur, Henry Thétard asked, 'Who was the first man who wanted to live in harmony with lions and tigers?' ('Quel fut 
le premier homme qui voulut vivre en harmonie avec les tigres et les lions?') ${ }^{18}$ Thétard answered his own question by drawing on Rudyard Kipling's The Jungle Book to cite the main character, Mowgli, as the historical origin of lion-tamers. Without any apparent irony, Thétard claimed that it was Mowgli who first taught the master-words that control bears and monkeys to subsequent animal trainers. The slippage between fiction and fact in Thétard's narrative could be read as invoking what art historian Albert Boime has called the circus performer's 'double transgression of the real'.

Boime was not really thinking of animal trainers, but of the artists for whom the circus offered a response to the social norms of the day. Boime argued that for the avant-garde, the imaginary world populated by characters like Mowgli was more real than realism. According to Boime, the fantasies of the circus and the fair helped modernists reject a painterly realism that validated the vision of normalcy advocated by France's Republican political majority. Boime turned to the circus because he was trying to find a new way to understand the symbolists, and not because he was interested in lions or lion-tamers. Yet it seems to me that the layered transgressions of reality depended, all along, upon the startling presence of the lions and tigers who jumped through flaming hoops. And in that space of the unreal, I wonder whether it was the irrepressible cries from the animal cages that enabled the aesthetic of pleasure, discomfort and control that allowed the avant-garde to redefine reality.

When Thétard's history of animal-tamers was published, his reviewer, André Legrand-Chabrier, described his story about Mowgli as a 'symbolical and allegorical and truthful portrait' of the animal trainer ('un portrait symbolique et allégorique et véridique'). ${ }^{19}$ Legrand-Chabrier pointed out that the contrast between Thétard's allegorical narrative and his technical expertise featured two different truths, the second and technical truth displayed in descriptions of raising tigers in extremely confining cages so they would feel unsafe in the open. Thétard's tigers were one among many of the species of the circus or the fair menagerie, which included domesticated dogs, chickens, pigs and horses, as well as lions, tigers, monkeys, camels and elephants. Like the human members of the circus, nonhuman animals were performers as well, albeit animals whose control and choice were more limited than most. Like most of the circus's human performers, animals were born with the circus or raised by their trainer from a young age. At the Cirque Médrano, which was a permanent structure, the animals were stabled on the ground floor, while some of the human performers had lodgings directly above them..$^{20}$ The relationship between these animals and their trainers, like 
the story of Mowgli, was a hybrid of real and performed violence, intimacy and affection.

Images represented this juncture of partnership and inequality as central to the work of animal trainers. Almost all mid-century images of French circus animals show trainers holding the whips that served as objects of protection, discipline and coded signalling. For example, artist Gustave Soury made a series of circus posters depicting the spectacle of an animal trainer holding out a whip to keep lions or tigers at bay while the big cats bared their teeth and batted at the whip. Other posters from the period used similar imagery, occasionally even showing animals wounding their trainers. But these were also affective relationships. One of Soury's study photographs offers a different image, with both more dominance and more affection, in which one of three leopards appears to be enjoying an ear rub from its trainer (illustration 29). Finally, consider Charles Levy's poster of one of the Cirque Fernando's horses (named 'Barbare' for his presumed ferocity) in costume as Pegasus, from a performance of the late eighteen hundreds (illustration 30). ${ }^{21}$ In this image, the Pegasus is posed like a wild animal in liberty, but its costumed wings are visibly strapped on, while the portrait of the circus's director,

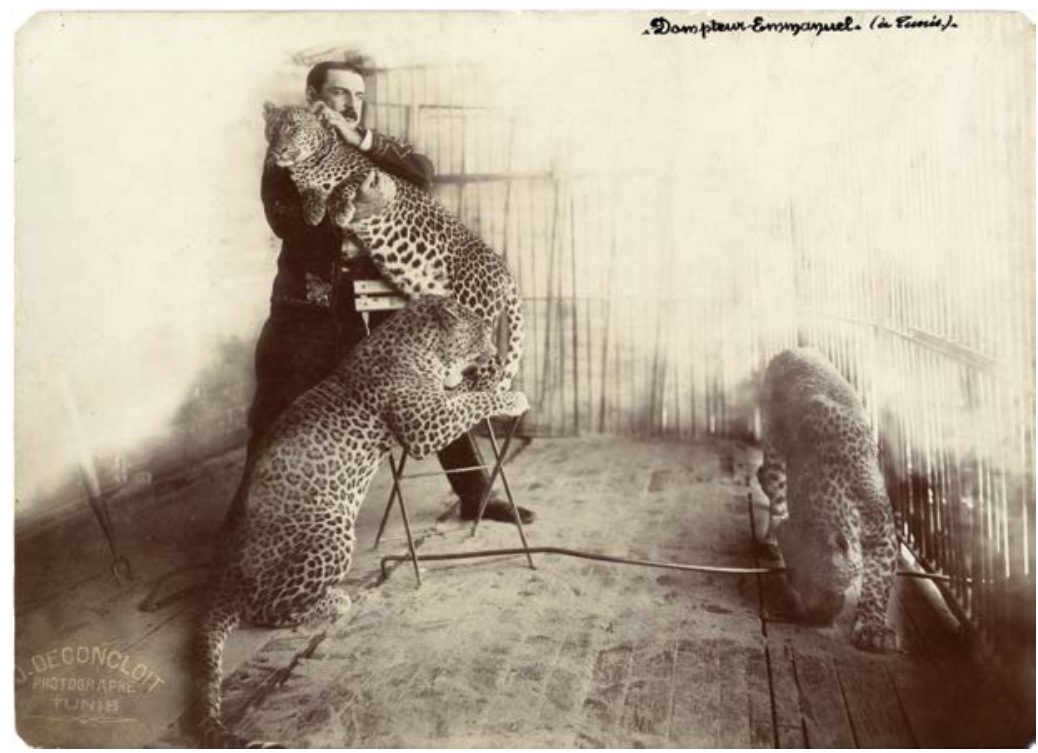

Illustration 29 Gustave Soury, photograph of Dompteur Emmanuel with his cats (date unknown). Image courtesy of Musée des Civilisations de l'Europe et de la Méditerranée, Marseille 


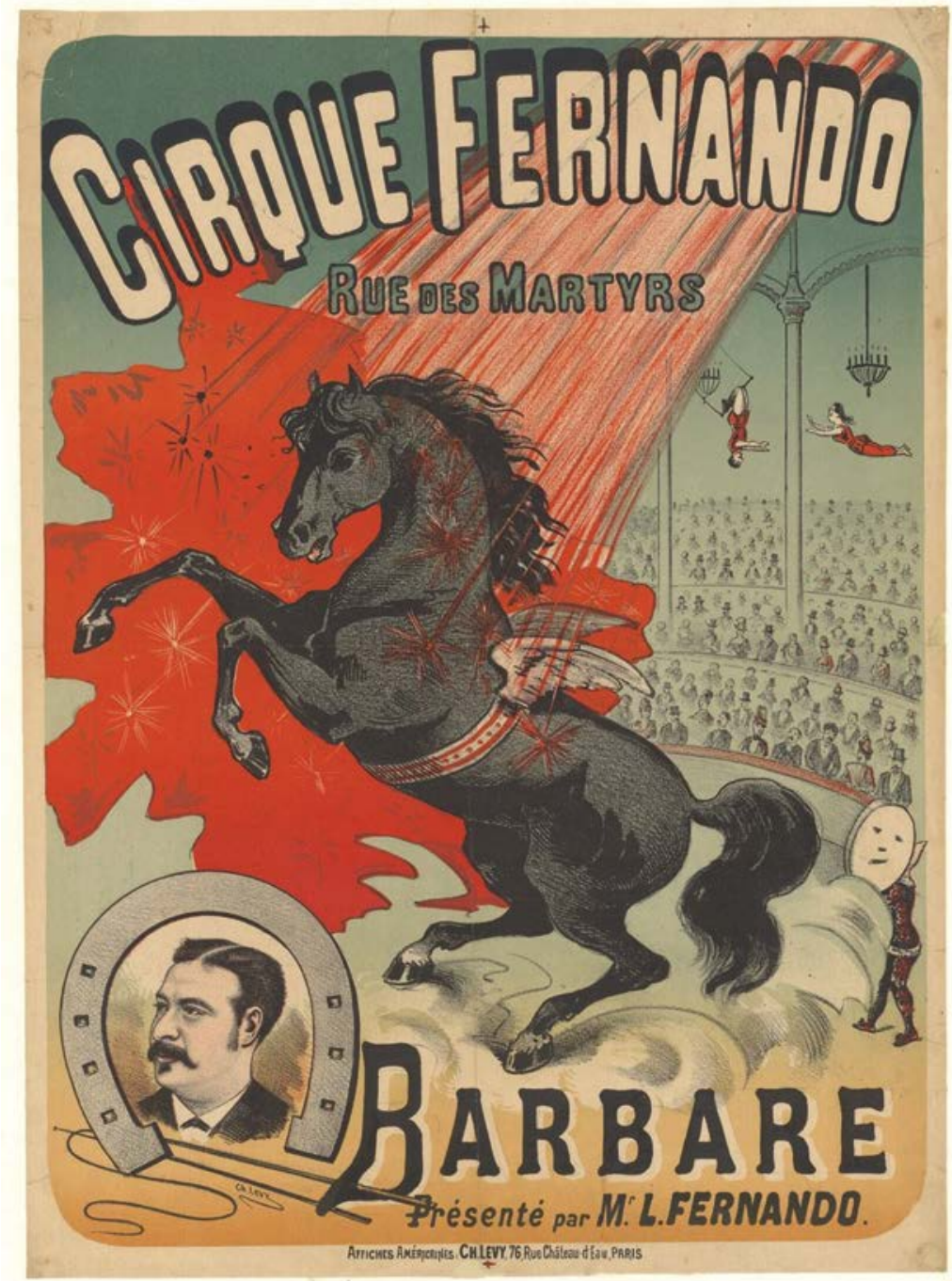

Source gallica.bnf.fr / Bibliothèque nationale de France. Département des arts du spectacle. AFF-17886

Illustration 30 Poster by Charles Levy of the horse Barbare performing at the Cirque Fernando circa 1885, with inset portrait of Louis Fernando. (C) Bibliothèque nationale de France. Image courtesy of Bibliothèque nationale de France, Département des arts du spectacle, AFF-17886 
Louis Fernando, which is encircled by a horseshoe, is a reminder that this image of liberty is controlled by Fernando. Barbare's plight is surprisingly echoed in 'Le Cheval' ('The Horse') in Apollinaire's Le Bestiaire, in which the poet forcibly tames and rides Pegasus.

This double transgression of the real extended to the contested artistry and status of the human performers. Cocteau wrote in 1919 that the circus, and by extension its performers, was not art but inspiration, comparing them to nature, animals and machinery. ${ }^{22}$ In his study of George Seurat, Albert Boime traces the marginalised status of Parisian circus performers to the turn from the nineteenth to the twentieth century, when the banquistes, or circus performers, were subject to restrictive government legislation. This regulation was framed in part through the legislation of sound, which targeted the cacophony of animal cries, brass bands and gunfire that issued from the circus and fair sideshows. ${ }^{23}$ In 1887, a petition from residents of boulevard de Clichy garnered over 380 signatures protesting at the noise from the fair. ${ }^{24}$ According to Karin Bijsterveld, such anti-noise legislation can be connected to the regulation of social class through residential zoning and similar laws. ${ }^{25}$ Thus when clowns and circus animals were admired and valorised by the likes of Cocteau, Satie, Picasso, Seurat and Degas, artists and composers both contested and relied upon a social order that divided the trained horse from the horse's trainer, and the painter or musician from the clown.

Despite this, it's still meaningful to me that artists took joy in the circus's temporary disruption of society's categories. In addition to the layered performance of power and intimacy in animal performance, the Médrano itself transgressed and enforced divisions between performers and audience. The circus's bar was also the break room for performers, and, during intermission, patrons would mingle with human performers and even smell the animal performers, since the stable was located directly below the bar.

The same year that Thétard published his history of animal trainers, 1929, a music professor at the Schola Cantorum in Paris completed two symphonic works for his Le Livre de la Jungle that, like Thétard's history, used Rudyard Kipling's The Jungle Book as inspiration. In the first of the two pieces, 'La loi de la jungle' ('The law of the jungle'), the instruments of the orchestra represent the jungle animals reciting their laws in a modernised version of medieval French chant. With all the instruments moving together to create a single melody, the primitive, the animal and the exotic are framed around and through the same tradition of medieval chant that underlies Honegger's understanding of the 'Prose de l'âne'. 
In the second piece, 'Les bandar-log' ('The bandar-log'), the orchestra runs amok as orchestral monkeys attempt to deploy a riot of dissonant counterpoint that sounds suspiciously like atonal German modernism. With these sounds of animal intention, I return from the relationship between biological species to the relationship between musical species, and to the processions of musical difference favoured by Les Six.

\section{E}

\section{Éléphant}

My bestiary concludes with a final animal act that, like the ass, travelled from North Africa into European culture: Babar, the elephant from Jean de Brunhoff's children's book of 1930. Babar was recomposed as a musical elephant in 1940 by Francis Poulenc; Babar's life is told in a series of charming musical episodes that navigate interspecies tropes of power, intimacy and violence through a procession of musical styles. Early in the story, Babar witnesses the murder of his mother by a colonial hunter in Africa; he soon travels to Europe, where he joins a rich old lady and, later, his elephant cousins.

The soundscape of Poulenc's L'histoire de Babar le petit éléphant is reminiscent of the carnival that wafted through Milhaud's windows before the war. Each scene in the story is set to its own short musical episode. The gunshots and animal sounds of the narrative are framed by a parade of musical styles: a Chopin nocturne as Babar walks in the jungle, a march as he drives his car, and a waltz-musette, Paris's street version of the Viennese waltz, as he eats tiny cakes in a tea shop with his cousins.

Like the other works I've described, Babar relies on the listener's ability to recognise and associate musical difference with differences of race, class, nationality, gender, sexuality and biological species. A similar procession of stylistic diversity defined works like Koechlin's Jungle Book, Poulenc and Durey's settings of Le Bestiaire, Honegger's Jeanne d'Arc and Saint-Saëns' Carnival of the Animals. Their animal works, like so many other works, highlight the parallel between musical and biological species that was already implicated in the shared use of 'species' to described biological and musical difference. German counterpoint, baroque dances, brass military marches, street tunes: musical difference gave composers a language that associated sound with a broader notion of difference that included categories like nationality, species, race, class or gender. That 
association intersected with the growing discourse in the 1920s and '30s about national identity that used differences of race, nation and gender as a way to compare and evaluate the worth of individual citizens.

By returning to World War II as the broader setting of Poulenc's Babar and Honegger's Jeanne d'Arc, I also return to the interwoven histories of power and animal identity that shaped modern notions of difference. Some of the works I've discussed in this short essay, like Koechlin's parody of German modernism in 'Les bandar-log', seem to have encouraged listeners to do that work of evaluation and comparison; for me, however, the most carnivalesque of these works are the ones that don't. The two settings of Le Bestiaire, whose texts are filled with the consumption and destruction of animals, parade musical styles serenely by in a procession of aural diversity that seems devoid of distortion or judgement. Poulenc's Babar is equally resistant to the comparative interpretations that made it possible, wafting through waltzes and nocturnes as if they shouldn't be compared or judged, but enjoyed.

As I continue to explore the slippage between musical and biological species, I would argue that for the French modernists, navigating biological differences of species was always and already a matter of navigating differences of class, race, nation, gender, sexuality and, by extension, genre. The notion of species in musical writing of the period was usually a reference to natural history, and implied a confirmation of the natural order. But it seems to me that works in which musical species arrived in a procession of episodes contested that order from within. France's musical animals were composed almost exclusively by men of education and social standing. Yet many of these works open up a possibility of hearing musical difference as a festival rather than an act of comparative evaluation. And, like Apollinaire's Le Bestiaire, they keep within earshot the acts of violence and hierarchy that define relations with those who are different. Even though that festival of music was still contained within the categories or norms of its time, it provides a playful possibility for rethinking the parade of difference in the postwar, post-modern and post-human world in which we live today. 


\section{Notes}

1 Duncan 1911, 40. See also Lacroix 1878 and Kidson 1907.

2 Textbooks of the early twentieth century by authors such as Jules Combarieu and Vincent D'Indy framed chant traditions from France as the foundation of later German contrapuntal traditions. An excellent resource on the turn towards Gregorian chant as a story of French cultural origins is Bergeron 1998.

3 See Fulcher 2005 and Sprout 2013.

4 Wartime concert repertoire is described in detail in Chimènes 2001.

5 Cocteau, who claimed to be the leader of the group, wrote in 1919 'The creative artist must always be partly man and partly woman, and the woman part is almost always unbearable' (Cocteau 1921, 12).

6 Darius Milhaud, unpublished draft as quoted in Kelly 2013, 185.

7 Arnaud 2016, 291.

8 See, for example, 'Le Wattman' 1921, 4; Legrande-Chabrier 1922; and Guide des Plaisirs à Paris 1927.

9 Schmidt 2001

10 Cocteau 1923.

11 See Picker 2003.

12 Cocteau 1921; for other descriptions of music in public spaces of fair, menagerie and circus, see also Scott 2008, as well as Craft 2010 and Ito 2014.

13 Wall 2013, 227.

14 See, for example, Scott 2008 and Cowgill 2013.

15 The recording is reproduced in French and American Circus - Zirkus (Musiques de cirque), various artists (Caravage B003EX8LF6), 2010, CD.

16 Picker 2003, 69.

17 As in, for example, de Lens 1924 or de Lima 1930.

18 As quoted in Legrand-Chabrier 1929, 27.

19 Legrand-Chabrier 1929, 27.

20 Circopedia 2019.

21 Poster by Charles Levy of trainer Fernando and horse Barbare (Levy c.1885).

22 Cocteau 1921, 23.

23 Boime 2008, 83-7.

24 Boime 2008, 87.

25 Bijsterveld 2008, 189.

\section{Bibliography}

Anderson, J. 1883. Guide to the Calcutta Zoological Gardens. Calcutta: City Press.

Arnaud, C. 2016. Jean Cocteau: A Life, trans. Lauren Elkin and Charlotte Mandell. New Haven: Yale University Press.

Bergeron, K. 1998. Decadent Enchantments: the Revival of Gregorian Chant at Solesmes. Berkeley: University of California Press.

Bijsterveld, K. 2008. Mechanical Sound: Technology, Culture, and the Public Problems of Noise in the Twentieth Century. Cambridge: MIT Press.

Boime, A. 2008. Revelation of Modernism: Responses to Cultural Crises in Fin-de-siècle Painting. Columbia: University of Missouri Press.

Chimènes, M. (ed.) 2001. La Vie Musicale Sous Vichy. Brussels: Complexe.

Circopedia. 'Medrano floor plan'. Last accessed 19 July 2019. http://www.circopedia.org/ File:Medrano_floor_plan.jpg

Cocteau, J. 1921 (first published in 1919). Cock and Harlequin: Notes Concerning Music, translated by R.H. Myers. London: The Egoist Press.

Cocteau, J. 1923. ('Le coq') 'Les Échos', Le Gaulois (9 July):1.

Combaluzier, L. 1930. 'Les bals dans la rue', Le Journal (15 July):1-2.

Conlin, J. (ed.) 2013. The Pleasure Garden, from Vauxhall to Coney Island. Philadelphia: University of Pennsylvania Press. 
Cowgill, R. 2013. 'Performance alfresco: Music-making in London's pleasure gardens', in The Pleasure Garden, from Vauxhall to Coney Island, 100-26. Philadelphia: University of Pennsylvania Press.

Cox, J. 1995. "Le Théâtre forain:" Historical and Stylistic Connections between "Parade" and "Histoire du Soldat"', Music and Letters 76(4):572-92.

Craft, J.W. 2010. The Cincinnati Zoo and Botanical Garden. Charleston: Arcadia Publishing.

Deeter, A. and Peavler, R. 2014. The Mélodies of Francis Poulenc: A Study Guide. Lanham: Scarecrow Press.

Drew, D. 2001. "The Savage Parade - From Satie, Cocteau, and Picasso to the Britten of "Les Illuminations" and Beyond', Tempo, 217:7-21.

Duncan, E. 1911. The Story of the Carol. New York: Charles Scribner's Sons.

Durey, L. 1921. Le Bestiaire, ou Cortège d'Orphée. London: J.W. Chester Ltd.

Fermigier, A. 1967. 'Jean Cocteau and Paris 1920', Annales. Histoire, Sciences Sociales 22(3): 495-513.

Ferrari, G. 2002. "Le "populaire" comme materiau pour l'innovation musicale: Satie, Milhaud, Ives', Musurgia 9(1):61-74.

Fulcher, J. 2005. The Composer as Intellectual: Music and Ideology in France 1914-1940, 270-72. New York: Oxford University Press.

Guide des Plaisirs à Paris. 1927. Paris: Louis Bellenand et Fils.

Ito, T. 2014. London Zoo and the Victorians, 1828-1859. Rochester: Boydell Press.

Kelly, B.L. 2013. Music and Ultra-Modernism in France: A Fragile Consensus, 1913-1939. UK: Boydell Press.

Kidson, F. 1907. 'Noel', in Grove Dictionary of Music and Musicians, Vol. III, edited by G. Grove and A. Fuller-Maitland, 385-7. New York: MacMillan.

Kisling, V.N. Jr. (ed.) 2001. Zoo and Aquarium History: Ancient Animal Collections to Zoological Gardens. New York: CRC Press.

Lacroix, P. 1878. Science and Letters in The Middle Ages, and at the Period of the Renaissance, 242-3. London: Bickers and Son.

Legrande-Chabrier, A. 1922. 'De quelques parades', Choses de théâtre: cahiers mensuels de notes, d'études, et de recherches théâtrales 12: 78-82.

Legrande-Chabrier, A. 1929. 'Un Curieux Livre de M. Henry Thétard: L'histoire des Dompteurs et des Ménageries', La Rampe 490(Feb.- Mar):26-7.

de Lens, M.-T. 1924. 'Sur le chant des moueddin et sur les chants chez les femmes a Meknès', Revue de Musicologie 5(12):1.

Levy, C. c.1885. Poster by of trainer Fernando and horse Barbare, Gallica, last accessed 22 July 2019. https://gallica.bnf.fr/ark:/12148/btv1b53029540g.

'Le Wattman'. 1921. 'Nos Échos: On dit que...', L'Intransigeant 28 November:4.

de Lima, E. 1930. 'La Musique colombienne', Mitteilungen der Internationalen Gesellschaft für Musikwissenschaft/Bulletin de la Société internationale de musicologie 2(3):95.

Miller, C. 2003. Jean Cocteau, Guillaume Apollinaire, Paul Claudel, et le Group des Six: Rencontres poético-musicales autour des Mélodies et des Chansons. Belgium: Mardaga.

Myers, R. 1977. 'A music critic in Paris in the nineteen-twenties: Some personal recollections', The Musical Quarterly 63(4):524-44.

Oxenhandler, N. 1954. “Jean Cocteau: Theater as Parade', Yale French Studies 14:71-75.

Peaslee, H.W. 1922. 'Park architecture: Bandstands', Architectural Record 51:269-74.

Peaslee, H.W. 1922. 'Park architecture: Zoological buildings', Architectural Record 51:360-70.

Picker, J.M. 2003. Victorian Soundscapes, 46-7, 69. New York: Oxford University Press.

Pittsburgh Department of Public Works. 1916. The City of Pittsburgh and its Public Works. Pittsburgh: Pittsburgh Printing Co.

Poulenc, F. 1920. Le Bestiaire, ou Cortège d'Orphée. Paris: Max Eschig.

Rabier, B. 1910. Le Cirque Harry-Koblan. Paris: Jules Tallandier.

Rasín, V. 1957. “'Les Six” and Jean Cocteau', Music and Letters 38(2):164-69.

Roe, S. 2015. In Montmartre: Picasso, Matisse, and the Birth of Modern Art. New York: Penguin Books.

Schmidt, C.B. 1995 The Music of Francis Poulenc (1899-1963): A Catalogue. New York: Oxford University Press.

Schmidt, C.B. 2001. Entrancing Muse: A Documented Biography of Francis Poulenc. Hillsdale: Pendrangon Press. 
Scott, D.B. 2008. Sounds of the Metropolis: The Nineteenth Century Popular Music Revolution in London, New York, Paris, and Vienna. New York: Oxford University Press.

Sprout, L. 2013. The Musical Legacy of Wartime France, 38-50. Berkeley: University of California Press.

Thétard, H. 1930. 'Chronique du Cirque: A Medrano, programme varié. Le Cirque d'hiver, doit-il redevenir un cinéma?', Le Petit Parisien 19(626):5.

Wall, D. 2013. The Ordinary Acrobat: A Journal into the Wondrous World of the Circus, Past and Present. New York: Alfred Knopf.

\section{Selected Musical Works Representing Animals}

1917 Georges Auric, Scènes de Cirque

1919 Francis Poulenc, Le Bestiaire ou Cortège d'Orphée

1919 Louis Durey, Le Bestiaire ou Cortège d'Orphée

1925 Germaine Tailleferre, Berceuse du petit éléphant

1936 Francis Poulenc, 'The Lost Dog', 'The Hedge-hog'

1937 Darius Milhaud, L'Oiseau (orchestral)

1938 Arthur Honegger, Jeanne d'Arc au bûcher

1940 Francis Poulenc, L'histoire de Babar, le petit éléphant

1952 Germaine Tailleferre, Conférence des animaux 
6

\section{Beasts of Flesh and Steel: The post-industrial bestiaries of Apollinaire, Dufy and Sutherland}

Matthew Senior

There is politics because man is the living being who, in language, separates and opposes himself to his own bare life and, at the same time, maintains himself in relation to that bare life in an inclusive exclusion.

Giorgio Agamben

Guillaume Apollinaire's Le Bestiaire ou Cortège d'Orphée is an eclectic modern bestiary, faithful to the medieval origins of the genre in its use of images of individual animals accompanied by texts explaining the symbolic meaning of each creature and its behaviour. But Apollinaire's bestiary is revived under the tutelage of Orpheus - not Physiologus or by any other explicitly Christian author. By mentioning Egyptian and Greek mystery religions and Hermes Trismegistus, Apollinaire harkens back to Jewish and Alexandrian sources that Physiologus and the later bestiaries borrowed from. In making Orpheus the patron of his bestiary, Apollinaire honours and invokes one of the originators of poetry in the West, who, along with Adam, is a primal gatherer and namer of animals. Unlike most medieval bestiaries, Apollinaire's work is a lyric composition, voiced by a first-person narrator. It is, overall, an exuberant, sensual text, brimming with energy and secular confidence in the human. Differing from its medieval predecessors, Apollinaire's Bestiaire contains none of the demonic, persecutory animals such as the hyena, 'which lives in the graves of men and feeds on their bodies', the manticore, a creature with a human face and the body of a lion that 'delights in eating human flesh' (illustration 31), or the basilisk, which can kill a man, 'simply by looking at him'. Nor does the Bestiaire contain disgraceful, sinful animals, 


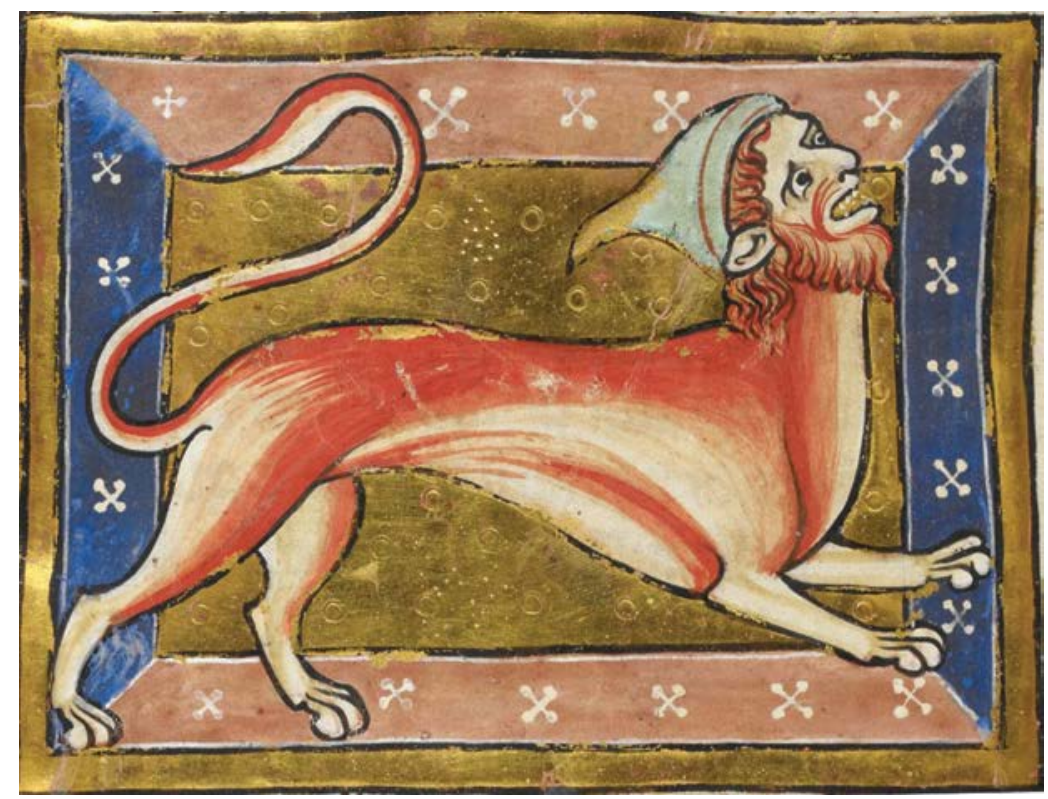

Illustration 31 British Library, Royal MS 12 C XIX (Bestiary), fo. 29v. Manticore. Public domain via Wikimedia

such as the 'hateful' ape, with its 'horrible and disgusting backside', the viper, 'the most evil of all creatures', or the 'cunning and unclean' partridge, characterised as such because 'the males mount each other and forget their sex in the grip of their lust'. ${ }^{2}$

At the inception and centre of Apollinaire's bestiary is the voice of Orpheus, which Marcel Detienne describes as follows: 'Orpheus is a voice, which resembles no other ... a voice that is anterior to the articulated word, around which, in the fullness of joy, trees, rocks, birds, and fish gather.' ${ }^{3}$ In Le Bestiaire, Orpheus's pre-metaphysical voice, as Detienne characterises it, is first identified with a line or a trace, 'la noblesse de la ligne', issuing from the light in the very first poem, entitled 'Orphée'. This voice, issuing from the light of creation, according to Hermetic doctrine, is expressed in the noble lines of Dufy's woodcut engravings and in the voice of Orpheus, as reincarnated by Apollinaire. ${ }^{4}$

\section{Expressive wood}

Woodcut engravings are an incision of the line - the voice of light - on a living medium, the wood of trees, which, like the trees that respond to the call of Orpheus, are part of the poetic process. The art historian Christina Neilson notes that, going back to antiquity: 
... wood was considered a living material that operated like a human body, with veins, humours, blood, and a complexion. According to Albertus Magnus, wood resembled the human body in that it could suffer, rot, be blessed, or infested with worms. Leonardo da Vinci believed that trees had humours; he compared the vessels of the human heart to the branches of a tree and drew analogies between the healing of a tree which has had bark stripped off and scarring in human tissue. ${ }^{5}$

\section{Animal flesh}

In the second poem, 'La Tortue' ('The Tortoise'), the Orphic voice is accompanied by and mixed with the sounds of a lyre composed of the shell of a tortoise and strings made from sheep gut. ${ }^{6}$ In the voice of Orpheus, Apollinaire speaks to his readers:

Du Thrace magique, o délire!

Mes doigts sûrs font sonner la lyre.

Les animaux passent aux sons

De ma tortue, de mes chansons.

Using the lyre of the magical Thracian [Orpheus]

My skilled fingers sound the lyre.

The beasts go by in time to my songs,

To the sound of my tortoise and my songs.

In this first speaking of the poet's voice, and throughout Le Bestiaire, animal bodies and specific parts of animal bodies are used to emit or express the poetic message. In the instance of 'La Tortue', the shell of a tortoise is used by the poet to accompany his song and attract animals and plants by speaking a language they understand. Further in the text, the reins of a horse, the fleece of a goat and the tusks of an elephant are used to disseminate Apollinaire's poetic voice. In Le Bestiaire, a visceral animal medium is essential to the message being conveyed. ${ }^{8}$ In distinction to medieval bestiaries, Apollinaire foregrounds himself and inserts his speaking voice into his bestiary. He seeks physical contact with his animal heroes and uses them to incarnate himself.

'L'Éléphant' is one of the most striking examples of this animal incarnation. Apollinaire says that, like the elephant, he has in his mouth a commodity of great value: 'Comme un éléphant son ivoire, J'ai en bouche 
un bien précieux' ('Like an elephant has its tusks, I have in my mouth a precious treasure'). Then, without transition or any anticipated rational meaning, the poet interjects: 'Pourpre mort!' Literally: 'purple death!' 'Purple death! ... I pay for my fame with melodious words.' Out of the poet's mouth, like the projection of the elephant's tusks, issue two juxtaposed words expressing a monochrome flood of purple and death: 'Pourpre mort! ... J'achète ma gloire / au prix des mots mélodieux.' The spiritual message the animal conveys emerges from its concrete, physical immediacy, just as the words of the poet are embedded in his mouth. There is the revelation of an ontological and biological truth - the reality of death, which humans suppress and cannot understand in any way, except through poetry - and the hope of a posthumous existence through literary fame and posterity.

Poetic writing and expression as a visceral animal process are also featured in 'Le Poulpe' ('The Octopus'):

Jetant son encre vers les cieux,

Suçant le sang de ce qu'il aime

Et le trouvant délicieux,

Ce monstre inhumain, c'est moi-même.

Squirting his ink to the sky,

Sucking his lover's blood

Finding the taste of it good

This inhuman monster is I.

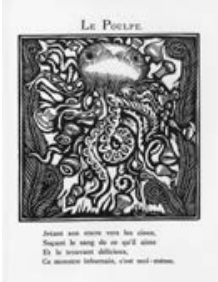

Apollinaire is the octopus, writing in the water, sucking the blood of his friends and lovers, becoming a monster, becoming inhuman. In the woodcut, the octopus seems to glare at the observer with two human eyes (illustration 5). This anthropomorphised gaze is common to several of the woodcuts. It was an aspect of medieval and early Renaissance representations of animals, especially in the bestiary tradition. The human-faced lion, from Villard de Honnecourt's Sketchbook (1225-35), is one of many examples (illustration 32).

In the poem entitled 'La Méduse' ('The Jellyfish'), the poet characterises these molluscs floating in the sea as 'malheureuses têtes aux chevelures violettes' ('miserable heads with violet hair'), probably an allusion to the French word for jellyfish, méduse, in recollection of the Medusa, who was decapitated by Perseus. Jellyfish delight in the chaos of 


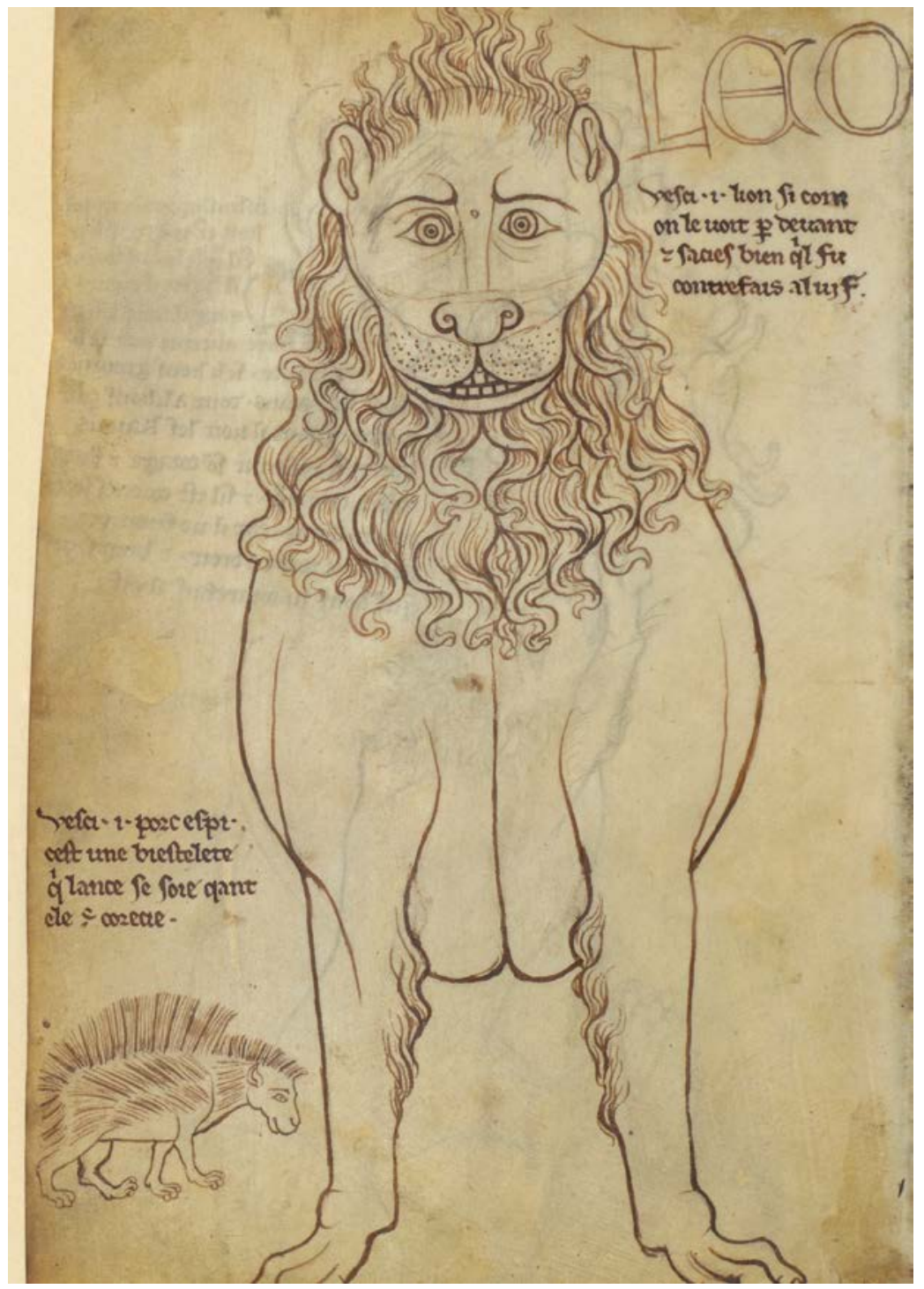

Illustration 32 Villard de Honnecourt, Sketchbook. 1225-35, Lion. Bibliothèque nationale de France, fr. 19093, fo. 24r. (C) Bibliothèque nationale de France, Dist. RMN-Grand Palais / Art Resource, New York 
storms, as does the poet. In another animal encounter, Apollinaire declares that the put-upon lover is like a man beset by fleas sucking his blood.

The face of the grasshopper by Dufy, in the woodcut accompanying the poem of the same name, is another example of an anthropomorphic face. The grasshopper reminds Apollinaire that this insect was the food of choice of the ascetic and visionary St John the Baptist, living in the desert. In an oral association similar to that of the elephant, Apollinaire hopes that his verses, like the grasshopper's body, will be eaten by the best people. This is an amusing downgrading and a wry domestication of an elevated symbolist myth, since St John the Baptist was a spiritual hero for the symbolists, who were fairly obsessed with the story of his decapitation and post-mortem visions.?

Another example of the animal body as the medium of Apollinaire's message is the case of the owl. The text reads:

Mon pauvre cour est un hibou

Qu'on cloue, qu'on décloue, qu'on recloue.

De sang, d'ardeur, il est à bout.

Tous ceux qui m'aiment, je les loue.

My poor heart is an owl

Nailed to the wall, torn loose, and then nailed again

Completely depleted of blood and force.

All those who love me, I praise them.

The bestiary genre allows Apollinaire to state directly that his heart is an owl nailed to a wall - a cruel custom he had seen in his youth while living in Belgium. This short poem is also an example of the confessional tone that makes Apollinaire such an authentic poet of happy and unhappy love.

The poem dedicated to the cat represents a more calm and content poet in love, in his home:

Je souhaite dans ma maison:

Une femme ayant sa raison,

Un chat passant parmi les livres,

Des amis en toute saison

Sans lesquels je ne peux pas vivre. 
I wish to have in my house

A woman in possession of her senses

A cat passing among the books

And loyal friends for all seasons

Without whom I can't live

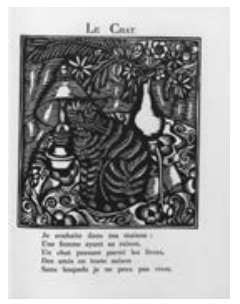

(illustration 4).

The poem gathers together all of Apollinaire's human and animal relations and his creative aspirations. Books, cats, friends and lovers all dwell together in his house. The oversize cat in the woodcut is the medium that expresses his desire for a complete life uniting books, female reason and animal life. The word for to live, vivre, rhymes with the word for books, livres

Contemplating this scene of private domestic life, and having recently read several of Giorgio Agamben's books about biopolitics, I am reminded of the words that Agamben cites from Aristotle to describe bare animal life, or zoē. The Greeks had two words that referred to life: zoe, which designated simple organic life, a life shared by humans and animals, and bios, which meant a higher form of intellectual and political life unique to humans. The Greeks considered the domestic sphere to be given over to zoē, and thus irrelevant and unavailable to politics. Looking at Apollinaire's happy domestic sphere, passing through the medium of the bare life of a cat, I find the words from Aristotle's Politics, cited by Agamben, to be perfectly evocative: '[M] ost men will tolerate much suffering and hold on to life (zoê) as if it were a kind of serenity [euēmeria, beautiful day] and a natural sweetness. ${ }^{10}$

What Aristotle says about the role of language in both uniting and separating zoe and bios in the human being is also relevant to the serenity and the beautiful day of zoè in Apollinaire:

Among living beings, only man has language. The voice (phōnē) is the sign of pain and pleasure, and this is why it belongs to other living beings (since their nature has developed to the point of having the sensations of pain and pleasure and of signifying the two). But language (logos) is for manifesting the fitting and the unfitting and the just and the unjust. To have the sensation of the good and the bad and the just and the unjust is what is proper to men as opposed to other living beings, and the community of these things makes dwelling and the city. ${ }^{11}$ 
Orphic language in Apollinaire's bestiary, containing both phōnē and logos, unites zoe and bios and locates the two within a house of being and language.

\section{Beasts of steel}

It is striking, therefore, to discover an entirely different sensibility in Graham Sutherland's illustrations for the The Bestiary some 60 years after Raoul Dufy's woodcuts. There is an animal viscerality in Sutherland's aquatints, faithful to Apollinaire's text, but it is unsparing, disjointed and jarring in its realism. The fly and the ox, animals which reveal
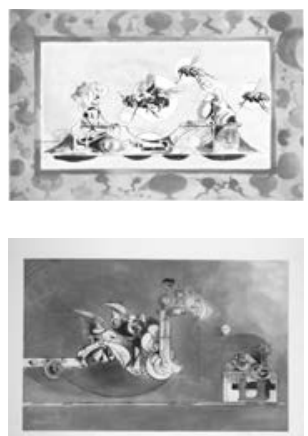
the highest spiritual truths in Apollinaire, are depicted as obscene and bestial (illustration 15). One wonders if, prior to Sutherland, copulating flies were ever represented in art. (It is true that Damien Hirst uses flies in his ghastly installations.)

Sutherland's third Orpheus illustration is almost entirely mechanistic. Small, distorted human figures are swallowed up by a gigantic factory or industrial process. (Illustration 16). The English artist's vision of the sirens is equally mechanistic and anatomical, in a disturbing way that is difficult to correlate with Apollinaire's text. In many of Sutherland's images, the bodies of humans and animals seem to break down into their component parts and combine in strange ways with elements of the mechanical and industrial world. There is an apocalyptic post-human atmosphere in Sutherland's Bestiary. It is a world where insects and rodents are represented with precision, often magnified, gnawing away, reproducing, and sucking blood with frenetic energy. These species seem to be thriving in a world where humans are crushed by industrial processes and have metamorphosed into weak, freakish hybrids. Graham Sutherland, along with Pablo Picasso and Francis Bacon, is one of the great post-humanist artists of the twentieth century.

\section{The screaming mouth}

Martin Hammer has analysed in detail the close personal relationship between and similarity in technique employed by Graham Sutherland 
and his younger protégé, Francis Bacon, during the war years, culminating in an exhibition in 1945 that featured art by both artists, including Bacon's revolutionary Three Studies for Figures at the Base of a Crucifixion, as well as Sutherland's Green Tree Form: Interior of Woods, both works characterised by a 'shared engagement with indeterminate biomorphic imagery. ${ }^{12}$ Sutherland's landscape works from the 1930s and 40s typically focus on single plants, roots and flowers that often seem to hint at animal and human limbs and appendages. During the war, Sutherland was a member of the War Artists Advisory Committee; he was charged with making images of bombed factories and neighbourhoods in London and Wales during the Blitz. Such paintings were meant to bear witness to the devastation of war and fortify the resolve of the British people by suggesting that humans could survive the catastrophes of war, much as they had triumphed over the titanic forces at play in mining and other industrial processes - the subject of much of Sutherland's most successful earlier work.

As the war was drawing to a close, Sutherland travelled to France to examine the devastation caused by RAF bombing raids on German positions. 'A lot of Germans had been killed inside the caves, and there was a terrible sweet smell of death in them ... There were bits and pieces of people knocking about, and I did some, but they were not allowed to be shown; and I think probably rightly. ${ }^{13}$ In another wartime reminiscence of the aftermath of a bombing raid in London, Sutherland reported, 'From butchers' shops which had been hit, the meat spewed on the road, and I remember feeling quite sick when seeing this for the first time because I thought that here was a body which hadn't been picked up. ${ }^{114}$ If, as Sutherland observes, the shattered bodies of bombing victims could not figure directly in his landscape and architectural art, the violence and suffering of the war was the subtext of his art. '[T]he writhing contortions of Gorse on Sea Wall and Midsummer Landscape recur in images of horrible twisted lift shafts and warped girders, evoking perhaps the skeleton of human or animal life forms that have been subject to destructive violence. ${ }^{15}$

Francis Bacon, like Sutherland, had a sense of the transitivity between the human and animal body, and between butchered meat and human flesh, which he used to great advantage in his most shocking paintings, most notably in Painting (1946). In a famous interview, David Sylvester asked Bacon about 'the conjunction of meat with the crucifixion', to which Bacon replied: 'Well, of course, we are meat, we are potential carcasses. If I go into a butcher's shop, I always think it's surprising that I wasn't there instead of the animal. ${ }^{16}$ 
Bacon's Painting and Three Studies, like Sutherland's writhing plants and steel girders, reflect, indirectly, by means of deformed, suffering hybrids and huge slaughtered carcasses, the brutal realities of the war and the Holocaust. Bacon had followed closely the iconography of fascism to be found in Nazi propaganda; he had abstracted particular traits from the faces of Hitler, Goering and other fascist leaders, as well as architectural motifs from the work of Albert Speer and visual details from Nazi films and images.

The three half-human, half-animal figures in Bacon's Three Studies recall some of the vengeful devouring beasts of the medieval bestiary tradition, such as the man-devouring manticore and the corpse-devouring

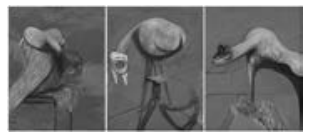
hyena (illustration 33). ${ }^{17}$ Hammer describes the mouth of the creature in the right panel as 'simultaneously a howling, yawning, or roaring beast and human presence barking out a stream of hysterical oratory, or else emitting some primordial scream of pain and anguish.' ${ }^{18}$

The screaming mouth is a recurring motif in the work of Bacon; it is, in all probability, the inspiration for the sombre, unexpectedly menacing mouth we see in Sutherland's illustration for Apollinaire's 'L'Éléphant'. In Bacon's case, the mouth expresses simultaneously the cries of victims of the London Blitz (much as Picasso had used the combination of human and animal cries in Guernica (1937) to represent the

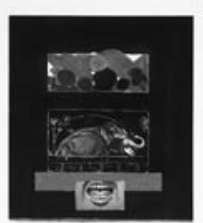
trauma caused by a German bombing raid) and the enraged shrieking of fascist orators and prison guards. When Sutherland contemplated illustrating Apollinaire's 'L'Éléphant', with its meditation on the poetic voice and death, he felt compelled to cite Bacon's screaming mouth (illustration 13).

Apollinaire's quatrain on the elephant concludes with the words 'mots mélodieux'. In this poem and elsewhere in Le Bestiaire, human and animal death are accorded dignity and ceremony. In 'L'Ibis' ('The Ibis'), the poet consents to his own death, under the aegis of the sacred bird of death in ancient Egypt. 'Oui, j'irai dans l'ombre terreuse. / O mort certaine, ainsi soit-il' ('Yes, I will go to the shadowy underworld. / O certain death, so be it, amen'). In Bacon's horrifying war images, human death is stripped of all ceremony and sacrality. Humans are disfigured and slaughtered, like animals. Sutherland's muted version of the screaming mouth is an allusion to the permanently altered poetic voice as a result of the wars of the twentieth century and the Holocaust. 


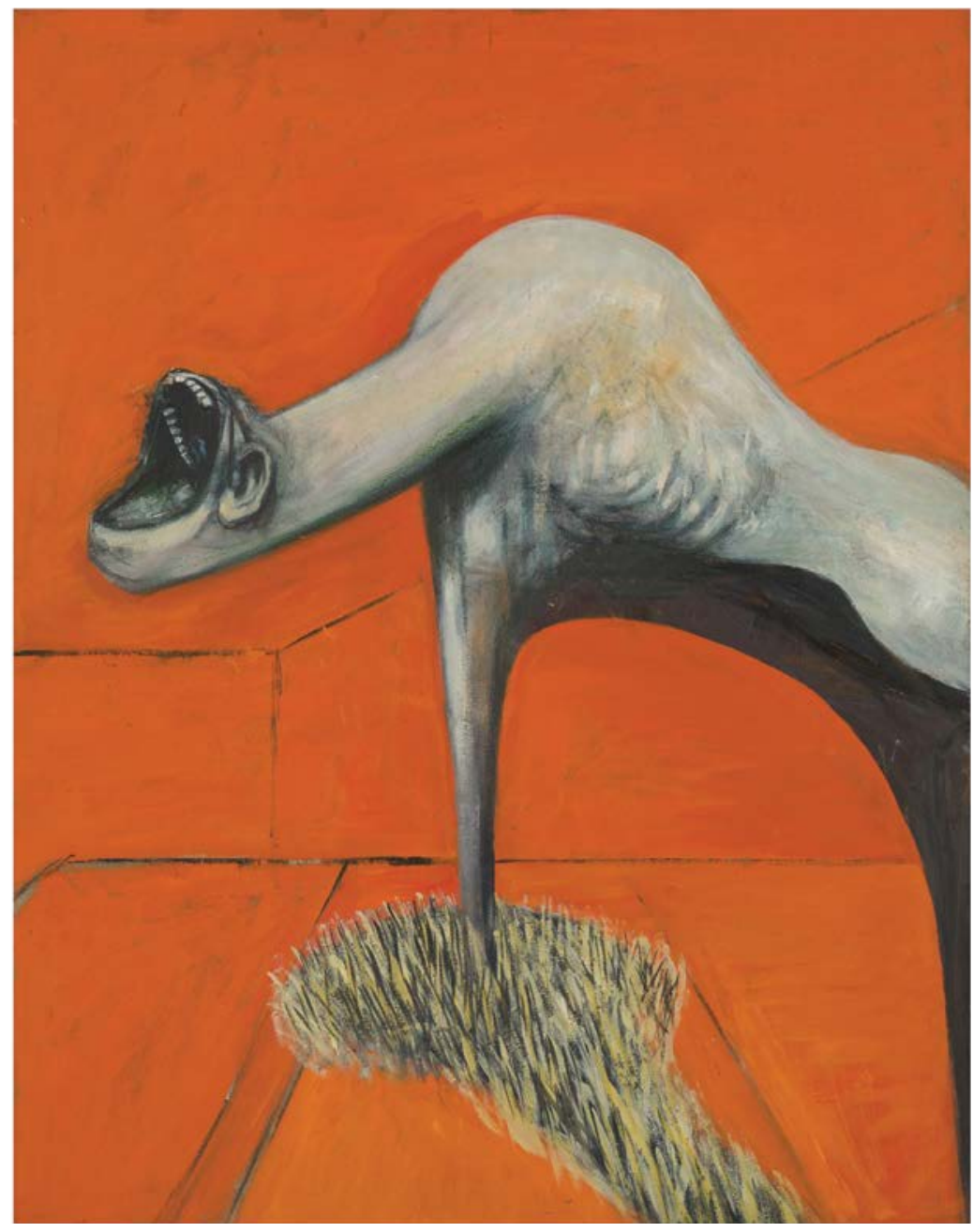

Illustration 33 Francis Bacon, Three Studies for Figures at the Base of a Crucifixion, 1944, right panel. (C) The Estate of Francis Bacon. All rights reserved. / DACS, London / ARS, New York 2020

If we wanted to speculate, one last time, about the kind of inexpressible voice or sound issuing from the screaming mouths of Bacon and Sutherland, we might recall two voices from World War II literature, one mentioned by Agamben in Remnants of Auschwitz: The Witness and the Archive, and the other occurring in Albert Camus's The Plague. In the first work, Agamben famously discusses the case of a mortally ill child in Auschwitz, named Hurbinek by the other inmates, from Primo Levi's 
The Drowned and the Saved. The anonymous child's very name, Hurbinek, is an assemblage of meaningless sounds he continuously murmured. The child also repeated another incomprehensible word, matisklo. Although this word had no assignable meaning, Levi recorded it in The Drowned and the Saved and passed it on to posterity, as the ultimate expression of the truth of the camps. ${ }^{19}$ In somewhat analogous fashion, the purely phonetic cry of a dying child, in Camus's The Plague, plays a similar role. In this novel, which Camus wrote as an allegory of World War II and the Holocaust, the hero-narrator, Dr Rieux, struggles against the relentless progress of bubonic plague, which ravages the city of Oran and reduces its inhabitants to burying thousands of plague victims in mass graves - a clear allusion to the Holocaust. At a pivotal moment in the novel, Rieux and his team watch helplessly as they cannot save the life of a child, whose final cry sums up what cannot be expressed otherwise:

He opened his eyes and gazed at Rieux, who was standing immediately in front of him. In the small face, rigid as a mask of greyish clay, slowly the lips parted and from them rose a long, incessant scream, hardly varying with his respiration, and filling the ward with a fierce, indignant protest, so little childish that it seemed like a collective voice issuing from all of the sufferers there. ${ }^{20}$

\section{Seeing bare life}

What I think I see in this exposure and vulnerability of human bodies, moving from Dufy to Sutherland, is the very biopolitical history that Agamben argues is the underlying tendency of twentieth-century politics. According to this vision, first popularised by Foucault, modern politics invades the private domain of $z o \bar{e}$ and makes the preservation and development of pure animal life the major focus of politics. The state is concerned with developing a large population of servile bodies for labour and war. With the replacement of the ancien régime by a republic, sovereignty is derived from the collective life of the people who have, first and foremost, an inalienable right to life.

Paradoxically, however, the state is invested with an all-powerful sovereignty over life itself. During a state of exception, such as war, revolution or a perceived threat to the collective health of the nation, the sovereign may take the life of his citizens without juridical consequences or symbolic guilt. For Agamben, the paradigm for this 
kind of absolute biopolitical power was the internment camps of World War II, in which men and women were reduced to the status of bare life and subject to endless work, medical experiments and extermination. Agamben sums up the isolation and quarantining of bare life by the modern state as follows: ${ }^{21}$

There is politics because man is the living being who, in language, separates and opposes himself to his own bare life and, at the same time, maintains himself in relation to that bare life in an inclusive exclusion.

By 'inclusive exclusion', Agamben means that the person reduced to the status of bare life is what defines society at the same time as what is excluded from it, placed beyond the protection of the law, and, in the worst cases, physically separated and confined in concentration camps or medical facilities. In this state of being inclusively excluded, in the most extreme cases the person loses the legal right to his or her own life. In addition to the camps, another example is the case of comatose patients who, although still alive, can be declared brain dead and their organs used for transplants. For Agamben, what is most telling about these situations is the way in which a human can be divided in two and a wedge drawn between their organic and civic life. For Agamben, biopolitics, philosophy and many other discourses in society converge to produce what he calls an 'anthropological machine' that produces, strangely enough, not integrated, holistic humans, but divided, layered humans whose bare life is exposed and available for labour and extermination.

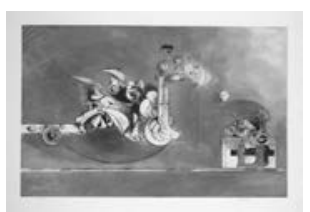

Perhaps, looking at Graham Sutherland's Orpheus, this is what we see: a sort of anthropological machine at work that swallows up naked humans and produces misshapen creatures (illustration 16). The siren might be a product of the anthropological machine as well: her viscera are laid bare and she is fitted with a kind of metal fin or navigational device, as she swims in contaminated industrial waters, her misshapen and

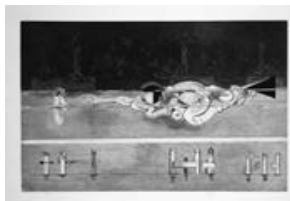
mutated arms stretching out towards the imperceptible remains of an equally mutated Ulysses, as Timothy Mathews commented during our collective visit to view the Sutherland Bestiary at Tate Britain (illustration 18). 


\section{Apollinaire, poet of flesh and steel}

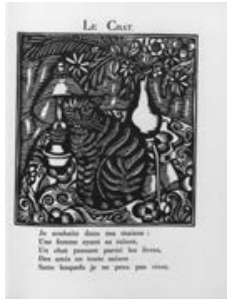

This jarring combination of flesh and steel in Sutherland is not without precedent and inspiration in Apollinaire. There are a few hints of metal and industrial processes in Dufy's woodcuts. In his dolphin engraving, a modern steamship plies the same ocean as a dolphin. In the cat engraving, a modern metal lamp can be seen - one can't tell if it is an electric or a kerosene lamp (illustration 4). The structure in the upper left side of the first Orpheus woodcut seems to be a miniature of the Eiffel Tower.

Apollinaire, in his work after Le Bestiaire, was as much a poet of steel as he was of flesh. In Alcools (1913), the latter-day Orpheus sings the praises of an industrial street in Paris, 'J'aime la grâce de cette rue industrielle' ('I love the grace of that industrial street'), and describes millworkers in the coal-mining districts of northern France as 'Les métalliques saints de nos saintes usines' ('Metallic saints in our holy factories'). ${ }^{22}$ Factory workers become Ixion turning his wheel in hell. Christ ascends to heaven like an airplane, establishing a new flight record for altitude. 'C'est le Christ qui monte au ciel mieux que les aviateurs / Il détient le record du monde pour la hauteur' ('Behold Christ who ascends to heaven better than aviators / He holds the world's record for altitude'). ${ }^{23}$ Apollinaire composed a sort of post-industrial fête galante in which 'Les becs de gaz pissaient leur flame au clair de lune' ('Gaslights piss their flame into the moonlight') and '... les roses de l'électricité s'ouvrent encore / Dans le jardin de ma mémoire' ('roses of electricity open into the garden of my memory'). ${ }^{24}$

Apollinaire is especially a poet of steel in his description of the shock and trauma of World War I. In a poem entitled 'Fête', he exclaims how beautiful exploding shells are at night and calls an artillery barrage a 'feu d'artifice en acier' ('fireworks of steel'), almost paraphrasing Ernst Junger's Stahlgewittern 'storm of steel. ${ }^{25}$ Apollinaire describes the love of danger he felt and 'the delicious anxiety' he experienced as bullets whistled past his face in the trenches and he taunted incoming artillery shells. The image of the vulnerable octopus reappears in his descriptions of the war. Such images abound in photographs of artillery teams wearing gas masks. ${ }^{26}$ Apollinaire was himself an artillery officer. In 'Océan de terre', he describes soldiers wearing gas masks with straps hanging down as 'poulpes aux becs pales' ('pale beaked octopuses'). ${ }^{27}$ 
Following an aerial bombardment, the soldiers prepare to leave the trenches. 'Attention on va jeter l'ancre / Attention à l'encre que l'on jette' ('Attention, we're going to raise anchor / Watch out for the ink being sprayed about'). Here, the ink of the octopus no longer signifies poetic expression, as in the Bestiaire, but rather a hail of bullets.

On 17 March 1916, Guillaume Kostrowitzky Apollinaire, who only days earlier had been granted French nationality and had attained the rank of sous-lieutenant in an infantry regiment, was wounded in the head by shrapnel from an exploding shell. He was treated and evacuated to Paris, where he underwent trepanation of the skull to relieve pressure on his brain, which was causing paralysis and other symptoms. These experiences of bare life were recorded in poetry and prose. In a poem entitled 'On les aura' ('We will beat them'), the poet mocks the exploding shell that wounded him by using a pun that plays on the double meaning of éclat, which can mean both a piece of shrapnel and a burst of laughter. 'C'est bien de rire aux éclats' ('It is good to laugh at shrapnel'). Later in the poem, Apollinaire evokes his own injury in a mocking pastoral style: 'Et naguère, au temps des lilas / L'Éclat tempêta sous mon crane' ('Some time ago, in the season of the lilacs, / A piece of shrapnel stormed within my skull.') ${ }^{28}$ In his last published poem before his death, 'La Jolie Rousse' ('The Pretty Redhead'), the severely injured poet described himself as 'Blessé à la tête trépané sous le chloroforme' ('Wounded in the head and trepanated under chloroform'). ${ }^{29}$

From the happy, pre-war, golden age of the bestiary and its celebration of a voice inseparable from zoē and animal life, Apollinaire would pass through some of the most dire zones of indistinction of the twentieth century, where the bare life of the human is isolated and becomes expendable: the prison, the battlefield, the hospital and surgery under chloroform. Looking back through two world wars and the relentless advance of biopolitics, I think it is inevitable that Graham Sutherland would depict Orpheus singing songs of flesh and steel.

\section{Notes}

Agamben 1998; my emphasis.

2 Descriptions of the manticore, hyena, basilisk, ape, viper and partridge are from Barber 1992, 45, 63, 184, 48, 186, 151.

3 Detienne 1995; my emphasis.

4 For a further discussion of Apollinaire's invocation of Hermetic theories of creation, see the essay by Sarah Kay in this volume.

5 Neilson 1987. 
6 According to legend, Hermes discovered the first lyre, composed of a turtle shell and animal entrails, lying by the side of a road, producing sounds caused by the wind blowing over its strings; the messenger god later fashioned his own such lyre, using the guts of a cow he had stolen from his brother Apollo. He was forced to surrender this instrument to Apollo in reparation for his crime. Apollo thus became the god of music; he later gave a lyre to Orpheus and taught him to play it. The story of Hermes and the origin of the lyre is recounted in the Homeric Hymns; see Hyde 1999, 317-31.

7 Citations from Apollinaire's Le Bestiaire ou Cortège d'Orphée are taken from CEuvres poétiques, Apollinaire 1959; for English translations of Le Bestiaire, I have used The Bestiary or the Procession of Orpheus, translated by X.J. Kennedy (2011), with minor modifications; translations of other works by Apollinaire are my own.

8 For further discussion of the symbolic importance of the living media upon which texts and images were inscribed in medieval bestiaries, see Kay 2017. Kay argues persuasively that the parchments medieval bestiaries were inscribed upon, derived from cleaned and purified animal skins, played a decisive role in their meaning, by establishing equivalences between human and animal skin in bestiary illustrations, and by constantly drawing attention to the dermatological medium of the message. Pages of animal skin, showing, in varying degrees, pores, scars, and other imperfections, and deliberately confused with human skin, constantly remind readers of their fallen, animal nature, but also the hope of redemption, proffered in the Bible, and in images of Adam before the fall, exhibiting 'skin as it might have been in Eden' (47).

9 See Curtis 2010.

10 Aristotle, Politics, quoted in Agamben 1998, 2.

11 Aristotle, Politics, quoted in Agamben 1998, 8.

12 Hammer 2005, 16.

13 Quoted in Gough, Moss and Goskar 2013, 35.

14 Quoted in Hammer 2005, 132.

15 Hammer 2005, 28.

16 Quoted in The Guardian, 12 September, 2007.

17 On the hyena and the manticore, see Barber 1992, 45, 63.

18 Hammer 2005, 17.

19 Levi 1988. Agamben discusses this passage in Remnants of Auschwitz: The Witness and the Archive (Agamben 2012, 38).

20 Camus 1991, 216.

21 Agamben 1998, 8 ; my emphasis.

22 Apollinaire 1959, 149, 150.

23 Apollinaire 1959, 40.

24 Apollinaire 1959, 129, 131.

25 Apollinaire 1959, 238. Ernst Jünger published his mémoire of trench warfare, In Stahlgewittern: Aus dem Tagebuch eines Stoßtruppführers, in 1920 (Jünger 1920), translated by Michael Hofmann (Storm of Steel; Jünger 2016).

26 For numerous images and maps of the terrain, the trenches, and the combat experiences of Apollinaire during the war, including photographs of artillery units wearing gas masks, see Janczukiewicz and Lefoll 2015.

27 Apollinaire 1959, 268.

28 Apollinaire 1959, 1031.

29 Apollinaire 1959, 313.

\section{Bibliography}

Agamben, G. 1998. Homo Sacer: Sovereign power and bare life, translated by D. Heller-Roazen. Palo Alto: Stanford University Press.

Agamben, G. 2012. Remnants of Auschwitz: The witness and the archive, translated by D. HellerRoazen. New York: Zone Books. 
Apollinaire, G. 1959. CEuvres poétiques, edited by Marcel Adéma and Michel Décaudin. Paris: Gallimard.

Barber, R. 1992. Bestiary: Being an English version of the Bodleian Library, Oxford MS Bodley 764. London: Folio Society.

The Bestiary, or Procession of Orpheus, 2011, translated by X.J. Kennedy. Baltimore: Johns Hopkins University Press.

Camus, A. 1991. The Plague, translated by S. Gilbert. New York: Vintage.

Curtis, L.S. 2010. 'Salomé, John the Baptist, and the spectator's severed head', in Symbolism, its Origins and its Consequences, edited by R. Neginsky. Cambridge: Cambridge Scholars Publishing.

Detienne, M. 1995. Les Métamorphoses d'Orphée. Paris: Snoeck-Ducaju \& Zoon.

Gough, P., Moss, S. and Goskar, T. (eds.) 2013. Graham Sutherland From Darkness into Light: Mining, Metal and Machines. Bristol: Sansom \& Company.

Hammer, M. Bacon and Sutherland. New Haven: Yale University Press. 2005.

Hammer, M. Graham Sutherland: Landscapes, War Scenes, Portraits 1924-1950. London: Scala.

Hyde, L. 1999. Trickster Makes This World: Mischief, Myth, and Art. New York: North Point Press.

Janczukiewicz, J. and Lefoll, N. 2015. 'Guillaume Apollinaire, poète de la grande guerre. 19141916', Lycée Arthur Veraquaux, Littérature et Société (blog), 26 January. http://1sgroupe1. blogspot.com/2015/01/guillaume-apollinaire-poete-de-la.html

Jünger, E. 1920. In Stahlgewittern: Aus dem Tagebuch eines Stoßtruppführers. Berlin: E.S. Mittler \& Sohn.

Jünger, E. 2016. Storm of Steel, translated by M. Hofmann. New York: Penguin.

Kay, S. 2015. 'Before the animot: Bêtise and the zoological machine in medieval Latin and French bestiaries', Yale French Studies 127:34-51.

Kay, S. 2017. Animal Skins and the Reading Self in Medieval Latin and French Bestiaries. Chicago: University of Chicago Press.

Levi, P. 1988. The Drowned and the Saved. New York: Simon and Schuster.

Neilson, C. 1987. 'Carving life: The meaning of wood in early modern European sculpture', in The Matter of Art: Materials, Practices, Cultural Logics c. 125-1750, edited by C. Anderson, A. Dunlop and P.H. Smith. Manchester: Manchester University Press. 


\title{
How is Orpheus honoured? Procession, association and loss
}

\author{
Timothy Mathews
}

Le Bestiaire ou Cortège d'Orphée - what sort of bestiary? What sort of a cortege, or procession? There seem to be a number of sequences involved, things are in a certain order that is nonetheless indefinite, and traditions have dissolved and exploded into association. Apollinaire in the first of his evocative little notes presents the book as an entertainment, and brings decorative and circumstantial elements onto the scene in his note to a beginning. Here is the first line of the first poem:

Admirez le pouvoir de la ligne

Admire the power of the line

Orpheus is there to give praise to the line, to give form and outline to images, and his own lines provide this bestiary, this poetic entertainment, with what Apollinaire in his note calls 'des magnifiques ornements', 'magnificent ornaments. ${ }^{1}$ A confusing signal, and the ornamental is combining with the magnificent in a way that eludes time and place. I'm reminded of the poet H.D., Hilda Dolittle, and her account of her meetings with Freud, which she called A Tribute to Freud and published in 1956. ${ }^{2}$ In his endorsement of the book, Ernest Jones twice uses the word 'ornament' or 'ornamental', as though this tremendous servant of Freud's thought were systematically outwitted by effects of surface and the idea of them. H.D.'s book is anecdotal, autobiographical, associative, probing, shaping. That interplay of surface and depth is also at work in the way Sutherland takes the place of Raoul Dufy, drawn into the enterprise by the randomness of a commission. And yet nothing addresses that interplay of surface and 
depth more simply or more evidently than Dufy's own woodcuts for the original book.

There is also the interplay between the practices of the bestiary and the more recent ones of the livre d'artiste, perhaps there is a transformation of one into the other, and beyond that the impulse of visual and verbal artists to understand their own work through each other's. What is spoken or left unsaid in the spaces in between? The artist George Shaw turns to the essay in curating his rehabilitation of Sutherland's work, and he is joined in the accompanying volume by the writer and artist combined, Brian Catling. Shaw has turned from image-making to words and found words for Sutherland's images, and these mediations involve earth, history and sex; as a reader and viewer, I am given over to the rhythms of these imaginary yet living proximities. ${ }^{3}$

Any sequence tells a story as much as it hides one, and the order of things is subject to various pressures, both visible and affective. But I'll try and start my own critical story at the beginning, although that beginning is a two-way pairing at least. What can I imagine Sutherland hearing and seeing in Apollinaire, and in Apollinaire's partnership with Dufy? What can I imagine about what is drawing Sutherland in?

Admirez le pouvoir insigne

Et la noblesse de la ligne:

Elle est la voix que la lumière fit entendre

Et dont parle Hermes Trismégiste en son Pimandre.

Admire the remarkable power

And the nobility of the line

It's voice heard in the light

Hermes Trismegistus speaks of it in Pimander.

What balance can there be between a quatrain and a picture, and especially when the picture is replacing another one? Between all of these pieces, a portrait of Orpheus is offered, but the poem doesn't offer a sitter. ${ }^{4}$ It is more as though it offers a portrait of its own addressee. Admirez! An unplaced someone is being asked to admire something, an idea of the line, and the capacity to have such an idea. But the imperative leaves an interrogation: what is left of this idea other than its badges? What are we supposed to admire? The exhortation to admire is scattered over the reading and viewing of these pairings, and the uncertainty carries on in the unbalanced symmetry of this opening poem. The four lines are divided into two groups of two, and each sings to the sound of a 
different moment in French poetry. The first two eight-syllable lines read like an allusion to Villon's ballads of urban festivity, also brutality, but the rhythm is so fleeting it might pass before it is noticed, and certainly before a full eight-line stanza by Villon would be over. Most of Apollinaire's poems for this book are stanzas of four lines with eight syllables, but five-line poems in a different metre also appear like bubbles in a stew. And the next two lines in this opening poem to Orpheus are 12-syllable alexandrines, giving a tiny snippet of neoclassical incantation.

When I first started on my own journey with Apollinaire's poetry, I remember wondering how to cope with this type of inconsistency. Now I'm more immersed in the sense that no one person has one voice and no two responses are the same. But still, when I first opened these pages I was struck that an attempt to feel the pulse of a tradition would end with a reference to thrice-great Hermes, and that there would be a note to the poem citing the second-century book of Pymander and the authorship of Hermes Trismegistus. ${ }^{5}$ Thrice-great Hermes is the name given by the Greeks to the Egyptian God Thoth; by a sleight of hand, or a stimulating fiction, or just the effects of time, Hermes or Hermetic or Trismegistic is the name given to the cycle of post-Christian mystical texts from Egypt. Apollinaire alludes to this confusion, or assumes it; he testifies to its absorption in a certain kind of knowledge, or memory, or is it oblivion? In any case this confusion or concentration is also a refusal to cohere. Gods, cultures and texts are each wrapped in different sorts of obscurity, and now they echo differently for each of us.

In a poem about the afterlife of Orpheus, about the myth of Orpheus and about myth itself, imagine rhyming insigne with ligne. The line's power is called remarkable and noble. Admire remarkableness and nobility in the line, embodied in the line and absorbed there. The idea of the line seems to get lost as much as to emerge in the line we're reading about; otherwise how could we imagine it, or why would we need to? A line and its sign, the sign that allows a line to come into being. Une ligne, un/insigne. But un insigne: that is an insignia. What as an epithet is remarkable, insigne, turns as a noun into a badge, un insigne: a punctuation mark in the common and the everyday, an identity mark or a decoration in the streams of the moment. It is like a little wave of the hand, and there is a voice there, one that is heard only as light.

In the catalogue to the showing of this work at Marlborough Fine Art, London, in 1979, Sutherland writes that a way for him into these poems was Apollinaire's fluid little series of notes to them. ${ }^{6}$ At the start of these notes, Apollinaire praises decorativeness, as I say, and at the same time evokes a cry emerging from the dark, and which also 
banishes its own darkness. 'Un cri inarticulé', 'an unarticulated cry', is producing the voice of light; it is made of light, and made into light. And now drawing and the lines of art have become the language as well as the voice of light:

Bientôt, lit-on dans le Pimandre, descendirent des ténèbres ... et il en sortit un cri inarticulé qui semblait la voix de la lumière.

Cette 'voix de la lumière', n'est-elle pas le dessin, c'est-à-dire la ligne? Et quand la lumière s'exprime pleinement, tout se colore. La peinture est proprement un langage lumineux.

Apollinaire quotes from the Pymander, authored under the name of Hermes Trismegistus: 'Soon darkness descended... and an unarticulated cry emerged from them which seemed the voice of the light.' And then Apollinaire responds: 'The voice of the light - isn't it the voice of drawing, in other words the line? And when light expresses itself fully, colour is everywhere. Painting is properly a luminous language.' Painting is the language of light. Light is a language and a sign; like all signs it shines the light of displacement, loss and life. Perhaps Sutherland doesn't need anything more than a fleeting sense of being drawn into these verses and poetic notes, anything more than something floating on the surface of the mind to allow living frames to emerge. His opening portrait of Orpheus, like the others to follow, is a portrait of an

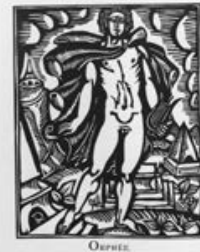
idea of Orpheus (illustration 1). The lines follow classical echoes, or perhaps they are themselves a renewal. In the same way, Apollinaire's note on light in 1911 echoes his experiences of Picasso's classicism in 1904, just as it anticipates his reading of Delaunay's art of colour from 1912. Sutherland's outlines of Orpheus renew the classical voices of balance, immediacy and grace that Apollinaire saw in Picasso's early Saltimbanque paintings, street entertainers, and before his cubist ones. For what is new, Apollinaire seems to ask, but the capacity to see as new, or as though new?

Sutherland's aquatint bleeds into these lines as well. There is a directness in the expression, but there is a resistance as well; the elements aren't coalescing. The face seems to stand out like a mask: its outlines become distinct with a look of the sculpted, despite the absence of the third dimension. Volume is nonetheless indicated by the lines of Orpheus's neck. Its parallel lines signal a kind of column for a plinth that looks like it might emerge from the single horizontal. Geometry has 
turned into its own kind of unarticulated cry from the dark. The idealised classical form that incorporates the balances needed to move and love; and then the Renaissance transformation of those lines into the perspectival a way of placing and knowing: that journey is both flickering in the dark and consigned to the dark in this visual overture to the entertainment Apollinaire is offering. Orpheus's hair is improvised differently from his face, and elsewhere in the series its wisps suggest geological layers or textures of earth. Figuration and dissolution; place displaced in a frame made of all sorts of frozen meltings and morphings: the procession is beginning.

If invention is the measure of human endeavour, its countermeasure is ethics. It is as though the distances between these words and this image suspended the violence of the world and were also filled with it. There is a deftness in Apollinaire's sparse notes to these tiny poems that is itself an emblem of poetic aspiration, and it reshapes the boundaries of the known and the imagined. Perhaps that is what Sutherland was so taken with. Following on from Orpheus, Apollinaire's next poem is to the tortoise. His notes continue to combine description, and the memory of something, with address. He reminds his readers that Orpheus's lyre was made of a tortoise shell with a leather trim. Its strings are made of the guts of a lamb. It has two branches, and there's an easel intimated as well, along with the bridge for the strings of instruments down the ages. In taming the animals, Orpheus uses an instrument that results from their slaughter and dismemberment. They are colonised, killed and made into implements. There are three of these prized lyres, Apollinaire notes, distributed by Mercury to Apollo and Amphion as well as Orpheus. Apollinaire mixes the Roman with the Greek mythological names, which sounds the confusion in the voices of culture and history, and of understanding and fantasy. This confusion harbours mobility but also merciless struggles for supremacy. Apollo and Artemis are later to kill Amphion's wife, Niobe, and all their daughters, leaving Amphion himself to nothing but suicide. Apollinaire goes on to call Orpheus's song un cantique, 'a canticle'; he merges without marrying the pagan and the biblical and all their different stories of crossing the borders of death. This whole procession of allusions, each lost in the rest, makes for a manmade vision, centred on the man in the moment; and it culminates in the clamour and the deafening acclaim of LE SAUVEUR. The saviour. But from what can mankind and its processions be saved? And at what cost?

Orpheus's art shows the ability to sing and play at the same time. The animals are not charmed by the sound, but simply come to listen - in fact even the animals, so not just animals but all living beings, animals 
and people together. 'Quand Orphée jouait en chantant, les animaux sauvages eux-mêmes venaient écouter son cantique.' This ability to draw an audience of humans and animals together soon slides into an aggrandised and idealised power of invention, the power to invent all the sciences and all the arts. 'Orphée inventa toutes les sciences, tous les arts.' In these few lines of accompanying prose poetry Apollinaire has captured the eclecticism of history as it is lived, without shape or motivation. He has discovered the lyricism in Orpheus's magic, the inner voice, not only lament but the open capacity for wonder.

But wonder is also entrapping, and the poem traces a journey lost in countless others from childlike belief to just belief. Magic has turned into the power of living ideas to shape, constrain, to form and enforce. It gives voice to the child within who sees everything that rushes in as a gift. Orpheus's science and his artist's vision extend to visionariness the power to read the future in the past. But the past is written like a catechism, and generosity is not prophesied as newness and rebirth, but preordained and commanded. Orpheus prophesies an insignia, and his song is a song of attachments to the decorativeness of what is. The word of God is given voice by all art and science, and all human knowledge at once illuminates and smothers the world in the light of its own time.

Here is the whole note, the prose poetry below the bar, perhaps the same bar or horizontal line that comes and goes in this series of compositions by Sutherland:

\section{Du Thrace magique}

Orphée était natif de la Thrace. Ce sublime poète jouait d'une lyre que Mercure lui avait donnée. Elle était composée d'une carapace de tortue, de cuir collé à l'entour, de deux branches, d'un chevalet et de cordes faites avec des boyaux de brebis. Mercure donna également de ces lyres à Apollon et à Amphion. Quand Orphée jouait en chantent, les animaux sauvages eux-mêmes venaient écouter son cantique. Orphée inventa toutes les sciences et tous les arts. Fondé dans la magie, il connut l'avenir et prédit chrétiennement l'avènement du SAUVEUR.

On the magical Thracian

Orpheus came from Thracia. This sublime poet played a lyre given him by Mercury. It was made from a tortoise shell with leather glued around it, two branches and a bridge, and its strings were 
made of lamb gut. Mercury gave one of these lyres to Apollo and one to Amphion as well. When Orpheus played and sang, even wild animals came and listened to his canticle. Orpheus invented all the sciences and all the arts. Grounded in magic, he could see into the future and in a Christian way prophesied the coming the SAVIOUR.

And here is the verse poem, above the bar and within in the realm of illustration:

\section{La Tortue}

Du Thrace magique, o délire!

Mes doigts sûrs font sonner la lyre.

Les animaux passent aux sons

De ma torture, de mes chansons.

The Tortoise

My sure fingers make the lyre sing

Of the magical Thracian, what a frenzy!

The animals pass by to the sounds

Of my tortoise and my songs.

It accompanies Dufy's woodcut, which like Sutherland's aquatint shows the lyre emerging from an upturned tortoise. Is it the tortoise or its shell? The animal, or the instrument arising from its exploitation? Dufy's

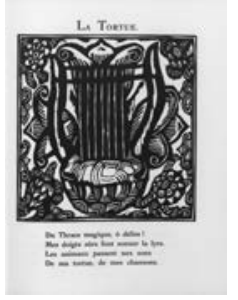
tortoise is surrounded by more animals, all animals, perhaps they're animals, emerging as much trapped in their insignia and their style (illustration 2). In the poem, Apollinaire firmly asserts his right to identify with Orpheus, le Thrace magique, 'the magical Thracian'. But straight away he addresses and invokes that identification as un délire - a delirium as much as an ecstasy.

The network of echoes carried in this tiny spell stretches as close to home as Rimbaud's Une Saison en Enfer of 1873 - Rimbaud's own imaginary journey into the underworld, the underworld of poetry and its fantasies of omnipotence. Its lightning-quick allusiveness tells a lacerating story of the word of God wrapping human creativity in its own history, its own light and language, and fear-driven colonisation. 
It shows a universe of senseless breakage, accompanied by glorified banners and bric-a-brac. The translation into the world now of a world still unknown is forever kept back, réservé, whether by wisdom or ignorance. Of this underworld of ignorance and arrogance, Apollinaire on this page has retained the way people insouciantly catch the past in the ephemera and emblems of the moment. Retained and admired. The little poem seems to bear witness to the voices in Apollinaire's mind of the manuscripts, designs and meters of the past, the many transitions in which their traces are dispersed and disseminated. He gives voice to this distillation of voices as though they were his own, anyone's own. The world and its beings slip by to the sound of my own voice, what else? Hardly surprising, then, that when it comes to the horse on the next page, the frenetic and chaotic energy of dreams fighting for breath will need reining in, and with all of Apollo's poetry of reason, championed by the one poet and idealised by him into the voice of all poets. Its sound germinates and grows - the voice of power, and of identifying with it. No wonder Dufy gives the horse wings and casts him as Pegasus.

Like Dufy's, Sutherland's tortoise is shown upturned, lying on its shell (illustration 10). But the whole tortoise is there, flesh as well as shell. And the transitions between flesh and shell extend to other shapes and outlines. Dufy's figuration shows the shell fully integrated with the lyre, subservient to it, it looks like something to hold it with, or a stand for it. But Sutherland's tortoise looks like a carcass. Carcass and lyre cloak and envelop each other. The sureness of touch in the poet's fingers that Apollinaire imagines are both murderous and infected. The tortoise's legs take the shape of the two branches Apollinaire reminisces about in his poetic note, and this confusion of the organic and the vegetal signals the visual associativeness that is embedded in Sutherland's picture as a whole. Association breathes life into all the pictures in the series and their interaction with each other. The fleshy legs of the tortoise, which are also the wooden arms of the lyre, have holes drilled through them for the strings, made of the sheep gut Apollinaire evoked before. The tuning pegs are also there, more reminiscent of a viol or a guitar than a lyre, but there they are, stretching the strings tight and putting the tortoise to the rack. Only two of its legs are shown, in profile; each one is different from the other and stretched towards the other, fit to burst.

But tension and violence are also dispersed. Each of the tortoise's legs also looks like an animal: different kinds of bird. The one on the right is stretched to the point of breaking its back, beak in the air and its three 
feet stuck out. And yet it still doesn't look like it is suffering, or no suffering appears after all; the markings in its side look like the sinews of its flesh. They might also be the markings of an obscure hieroglyphics, a writing rooted so deeply in a sense of body and earth that it has lost all voice. The bird or leg-bird on the other side seems far more poised: the tuning pegs are far more in tune with it and its appearance of mastery. Like buttons on a tunic. The head also seems to anticipate the head of the snake that appears later in Sutherland's sequence, later echoes and morphings that perhaps also involve elements of the ibex. It has a life ahead of it, and on its side there are four holes, even though there are still only three strings; so my mind wanders to two pairs of eyes, and looking back across at the bird or leg-bird on other side, I could imagine it having three eyes all on the same side of its head, or three feet. A cubist sort of composition, then, with everything laid out in the flat. Back on the left, the tuning pegs don't all look the same any more; the top one looks like the profile of another bird in a tiny miniature. And the whole bird, leg-bird on this side of the tortoise-carcass-lyre, is divided in two - two beings each with two eyes somewhere on their body, or are the ones on the bottom buds sprouting out of a pot?

What should I be making of these associations sprouting all over the picture? And of visual associativeness in response to a poem - a decorative poem about an iconic ancient poet? Perhaps nothing other than the overwhelming presence of association itself. Condensation and displacement together seem to provide not so much an explanation of how the history of an idea unfurls, but one of its forms. On its back like this the tortoise reminds me, as it might anyone thinking about humans and animals in art, of Kafka's Gregor Samsa waking up on his back in the body of a beetle. But Kafka's sliding and melting is loaded with the nightmare symbolism of his character's fetid and repressive family, erotic and professional lives. Here the associations are more open. Where Kafka's fantasy speaks to oedipal and capitalist symbolism and its dark internalisations, the associations of Sutherland's image speak to association itself.

Let's take the example of the trim of the shell, which is supposed to be made of leather. But here it is coloured yellow, like the glow of the ball of light to the right - is it light? In that case it is a light suspended above its source; there is a gap between light and source, the flames visually alluded to underneath. Flames reappear at various points in the series, not least in the last picture, where Orpheus, perhaps, is stoking up the funeral pyre of his own inspiration and the obscure objects of his desire. But here the yellow sings more clearly of the sun rising with 
Apollo, another recipient of Mercury's lyre. The whole image is cast in the family of yellow, but without uniformity. The shape of the glowing light is more to do with biology than physics; its kidney shape stretches out towards the organic and biological insignia on the head and legs of the tortoise. But no connection is actually made. Metaphoric purpose and perspective are broken up and dispersed in metonymic shapelessness and possibility. The decorativeness and entertainment that Apollinaire and Dufy offer is maintained in an admiration for the effects of the surface - formal surfaces as well as spontaneous superficiality. The easel that Apollinaire hears in Orpheus's lyre and the bridge for its strings un chevalet - has also been visualised by Sutherland in the form of a picture that might be standing on it. It is a white rectangle in the flat background, a background flooding back with its whiteness. It is quite an implacable whiteness, geometrically uncompromising. But it has all the possibility of a screen waiting to have projected on it what is forgotten just as much as what is seen. And little arrowheads underneath it, or are they conifers, give tiny mnemonics of memory itself.

In Sutherland, with Apollinaire the relation of wit to wound is always changing. And high art to decorativeness. Classical lines draw a model of human continuity - the continuity of inner and outer worlds, of love and generosity. But the same lines that explain a shared idea of beauty, the capacity itself to share, also show the human capacity for pain, the rips and tears and lacerations of broken desire and a broken self. Orpheus's lyre comes from domestication and slaughter, and his music claims to tame. And now his paths to the underworld, the unliving world, the world beyond human understanding, express the cruelty in which understanding is conceived, its placenta of unhappiness, both inflicted and accepted, and still waiting to be deciphered. He has the sound of his own song in his mouth; it sounds the echoes of the whole world which the whole world hears, but still he doesn't hear them. His skill defines him as it passes through him, leaving him at once in tatters and intact. The charm and the limits of his melodies sublimate the myths they carry, including his own which is still obscure to him.

Here is the poem to The Elephant:

\section{L'Éléphant}

Comme un éléphant son ivoire

J'ai en bouche un bien précieux.

Pourpre mort! ... J'achète ma gloire

Au prix de mots mélodieux. 
The Elephant

Like an elephant and its tusk

I've a precious good in my mouth.

Purple death! ... The price of my glory

Lies in my melodious words.

More even than charming the animals, by the power of analogy and its inherent narcissism Orpheus has now become an animal. Exactly like the elephant, it seems, his mouth is filled with a precious possession. A tusk for a lyre - and it is a lyre of death, cloaked in the purple of the Roman Empire. In that idiom, poetry has become about glory, something to be won, and Orpheus wins it at the cost of his own melodious words. They are the price to pay, but who is paying? Or hearing? Hearing what? To become the poet of all poets, Orpheus has been stuffed to the brim with his own words, stifled and gagged by them, like the awkward magnificence of the elephant's tusks. Under the bar that in other pictures might be a platform or the edge of a table, Sutherland has kept the mouth, separated from the elephant by all the frames in

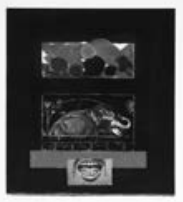
the picture as well (illustration 13). The separation of all the elements loosens the analogy between the poet and the elephant, but emphasises its meaning. Each has death in the mouth incomparably, and all the more implacably. What are the melodies of life, then, and how will they be heard?

The elephant is trumpeting and showering himself, and underneath the seafront railings that earlier separate the lion from his viewer there is the human mouth. Human and not animal; and not I, either. Orpheus has become the poet of all poets by speaking a language that charms what he is not, and by which he is ultimately abandoned. Loss cannot be charmed away even though it casts everything in the cruelty of its charm, and Orpheus cannot be charmed by his own song. As readers we cannot hear his song either, that song of our own making glistening in an unfinished story, whose melodies are made to the rhythms of words and not music. A buzzing in the ears, or so Samuel Beckett calls it, or rather in the skull; vowels seeking consonants and sentences, pushing their way through to a brain and a mouth that can never claim them, that still claim them, without knowing what is being said, begging for understanding in this torrent of distances. In 1972, audiences could see Billie Whitelaw's mouth speaking Beckett's Not I in the dark. It has been silenced by Sutherland's visual reproduction of it, which is unmistakable to me and maybe others, but 
maybe invisible to others still who might anyway see something different. Across his broken scribbles of relativity and inwardness, with Apollinaire and now with Beckett as well, Sutherland has joined in a miracle - a prolonged seeing, Apollinaire calls it in Le Larron, 'une vue oblongue'? It moves along lines as yet unseen, for their shape is an endless shaping; it is made known in the words of the moment, which it also makes. Putting vowels in the right order along the way, it gives voice to signs, the ones we're given to know, the loss they make, and the charms that sign our pain.

Orpheus himself makes another appearance in the next pairing of poem and image, in this procession of many Orpheuses. Orpheus appears in his own wake as well as the wake of those who follow him - a troubling intermingling which in this pairing involves foul underground insects, microbes and bacteria, rotifers and mites. But they are suddenly translated into the seven wonders of the world.

\section{Orphée}

Regardez cette troupe infecte

Aux mille pattes, aux cent yeux:

Rotifères, citons, insectes

Et microbes plus merveilleux

Que les sept merveilles du monde

Et le palais de Rosemonde!

And in Jean Wood's translation, which she provided for the Marlborough catalogue:

\section{Orpheus}

Look at this foul throng

With a thousand feet, a hundred eyes:

Rotifa, mites, insects

And microbes more marvellous

Than the seven wonders of the world

And the palace of Rosamund!

This is more like a substitution than a translation; things are being replaced, given life by suppressing what has gone before. ${ }^{8}$ Perhaps that is the nature of translation, witnessed in adaptation as well. Giving voice to the underworld involves giving it the voices of what terrifies and 
revolts in the moment now. But this substitution is also volatile, and aversion and attraction combust. With no transition at all, in the last of these six lines, and wrapped in the voice of Orpheus, Apollinaire transports marvels of filth into the marvels of love and sex. These marvels cloak everything and they become increasingly constricting. Eurydice is lost in the body of Rosamunde Clifford, the love of Henry II of England, and the love of his life, as legend has it. And in Apollinaire's other poem called 'Rosemonde' in Alcools, the name of Rosemonde, the name of the narrator's love and fantasy of the moment, is made literal and comes to mean the rose of the world. Poetry has become the voice in which echoes are condensed, made indistinguishable from each other, dispersed and silenced in present noise. Rosemonde's name is further condensed into her mouth: the world, the word, the French word monde, are pushed into the German word Mund. The rose of the world is nothing but a mouth for the kissing. But it is an emblem of a mouth, strongly desired yet still out of reach, at a distance that continues to wound even in the tonguing and the saliva passing between people.

Voyeuristic eyes are perched everywhere over wave-shaped plinths and lurk at their base as well (illustration 14). Sutherland follows the trail of Orpheus over their crest, and by now the Orphic vocation is well and truly soldered to the word of God:

Orphée

Que ton cœur soit l'appât et le ciel, la piscine!

Car, pécheur, quelle obsession d'eau douce on bien marine

Égale-t-il, et par la forme et la saveur,

Ce beau poisson divin qu'est JÉSUS, Mon Sauveur?

Orpheus

May your heart be the bait and the sky the pool!

Sinner, which fresh water or salt water obsession

Can equal, either in shape or taste,

That beautiful divine fish that is JESUS, my Saviour?

The fusion of the Orphic, Hermetic and Christian traditions has become irreverent and implacable. Witty entertainment has become the idiom of indoctrination. Orpheus's heart is the bait Christ uses to fish for souls; 
the lake over which Christ walked to reach unbelievers and the heavens to which he invites them, both have the lovely colours of a swimming pool; sinners and fishers all agree their saviour will make himself known in the taste of the fish. He has multiplied the fish, transformed them, but now He has assumed their form. Even present in the fish on a slab, Jesus still needs the taste of fish to be remembered. Cause is lost in effect. Apollinaire involves Orpheus and his readers in ever-decreasing circles of association. This decreasing condensed sphere of influence parodies belief while also showing its tenacity and the shapeless unpredictability in which it hibernates.

Sutherland's image in response gives much to wonder about in the relations of surface to depth, as well as wit to anxiety (illustration 16). The picture is dominated by its green: the swimming-pool is green; how would you have guessed it was a swimming pool at all? Not without the poem, maybe, and not without reading or perusing these visual forms in some associative manner, criss-crossing between the elements in a hundred possible sequences. Sutherland's shapes enclose further ones and disclose further ones still. The effect is simulated at some thematic distance by his own criss-cross designs and their dissolving content. Up in the middle right, there is a high diving board with Orpheus jumping off, or it could be anyone, and Apollinaire's increasingly strong identification with Orpheus is turning into the voice of identification itself. At this point anyone could be taking the high jump into their own life, were they not already submerged in it, and seeking just as much what they do understand as what they don't.

Such is the world each one of us stands on, it seems, at a far distance from our own grasp, up there at the top of the picture. Distant, and also immersed in an associative network weaving an identity we may come to recognise while still not claiming it. The construction on the right has something of the Apollonian flame with which this story began and with which Sutherland's sequence ends. And on the far left there are what look like contemporary industrial bolt heads. In between there is a continuous reshaping - a process that isn't abstract, since the forms in the picture carry meaning. But once again, this reshaping isn't meaningful either, since its shapes offer not multiple and condensed meanings, but unstable ones that displace and replace each other. Organic and machine-like, vegetal and sexual, human and ornithological, balletic and violent - there are a weave of associations here that can't be explained away or owned. It is an indefinite and intransitive weave that produces 
a way of reading and seeing rather than a tapestry or a mesmerising snapshot. What is mesmerising is a way of seeing. Something is provisionally witnessed in reading the picture as a series of sequences that cover over their own traces, just as something is also witnessed in the space separating the image from the echoes of Apollinaire to which it responds and which it renews.

My own story is reaching its end, which will not be the end of the story in these two books of Apollinaire, Dufy and Sutherland. It has been a story that has unfurled associatively, driven by the mobility of form and the invitation to invest in it. And yet even though his story has no beginning or end, with his associative, rhizomic tentacles, Sutherland with Apollinaire has been exploring the way all stories are fashioned in the image of the one who hears them and tells them. One and not

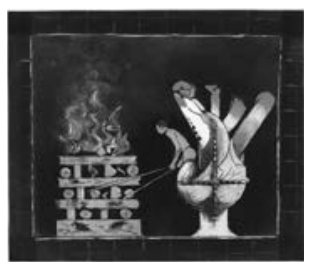
another. He adds a picture to the sequence, one he feels expresses what has been happening. I mentioned it at the beginning; there is no poem to go with it, and he calls it 'The Pyre' (illustration 20). Orpheus, I feel, is stoking up the fires - but of what? Like an elephant rider perhaps, his pokers also look like reins - but what is he trying to direct? Behind him are the outlines of the Apollonian flame, or the just the torch that appears every once in a while, including by the tortoise-shell lyre towards the beginning. This time the flames sprout the feet of the flea, perhaps also the head of the snake, or of birds, whether the ibis or not - in any case, just some of the still-unexplained pressures that have fashioned the vocabulary of Orpheus in Sutherland's recreation, and by which he has come to be known here. On the other side, the flames can look like leaves or lilies opening. Orpheus is setting fire to his own charms, it seems, and to his own incapacity to see beyond them, even their diversity, or to hear their melody, even its unpredictability. He hears only them and cannot hear them at all. Can he set fire to the deafness that has sailed across to him over the years of his life?

Sutherland and Apollinaire together seem to invite generosity and to seek it out in responding to the lyricism of Orpheus's predicament and his pain. Orpheus is honoured in Le Cortège d'Orphée, and Apollinaire has punctuated his bestiary with those various poems devoted to the charmer of animals. He is also the charmer of the underworld, turned charmer of death, and from there inexorably the saviour of humanity. Here we are again. What is there for humans to save if not ideas of the human? Or the desperate idea itself of saving - but from what wounds? Sutherland takes the leap and associates Orpheus with SigMund Freud 
(illustration 17). Not in response to a poem about

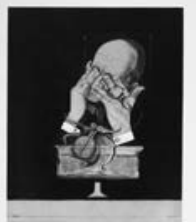

Orpheus, but about the octopus. Apollinaire has heard the voice of Orpheus; it seems to press on him and disappear from him at once, like the vanishing point in the lines of a perspective. Sutherland has included those lines in his picture, the disappearing lines of a transparent cube in which Sigmund is sitting. It suggests an echo chamber, a disturbing one that continues to reverberate even though the walls are disappearing. Who knows what the source is of what we hear and see?

But hear and see we do, individually - and in one tapestry of ways, not another. The unfinished quality of this translucent chamber or cube shows how we might have become engrossed in it. As a reader and viewer, I'm all the more engrossed in my hearing and seeing for battling away with them, pushing and pushing for revelation. The weave of fascination loosens and tightens at once. Sutherland's disappearing cube reaches out to Francis Bacon's cubes, but without finding them, and the octopus itself is dressed in the colours of Bacon's screaming pope of $1953 .{ }^{9}$ It is cloaked in the allusions that belong to the moment of this painting, just like all the others in the sequence, whether this allusive film is visible to people or not, and whether or not an artist or anyone can ever hold the reins of her own style. Sutherland shows Freud pressing his eyes in fatigue or in some despair of his own. Under his cuffs there is what looks like a coffin; or perhaps it is one of the three caskets through which Freud meditates on King Lear's three daughters, and fear and resentment of death ${ }^{10}$ - Lear's fear and resentment of death, Freud's own, anyone's. Each seems to speak a language inexorably its own, removed from others by its own ways of absorbing them.

In the poem, Apollinaire calls the ink of the octopus his own, just as his identification with Orpheus has infiltrated his whole book. The octopus and Orpheus are both sucking the blood of the world they love, the only world they know. It is the only way of loving they know. Look a bit closely at Freud's fingers and they take an erotic form: buttocks and legs. The basis in sex of Freud's discoveries is both explosive and reductive. One depends on the other, the explosive and the reductive. The poetry of the inhuman, through which Apollinaire sometimes voices his Apollonian ambition to challenge the complacency of the human, is now the voice of monstrous human voraciousness, wrapped in the wounds of its own love. 'Ce monstre inhuman, c'est moi-même'. 'I am this inhuman monster'. And on the next page, Sutherland has drawn the 


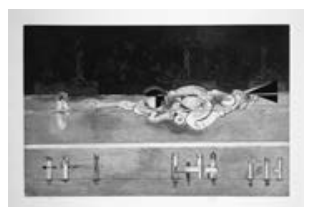

sirens of his own time in a pitch of lyrical tension (illustration 18). Instead of the sirens being confident in their power to entrap the object of their charms, now it looks as though it is the sirens' own pain that propels them over the seas.

The seafarer is all but lost to them; it seems they will never reach him, for he is lost in their seeing and is only theirs to see.

\section{Notes}

1 All translations are mine unless otherwise indicated.

Dolittle 1984.

Shaw 2011.

4 All quotations from Apollinaire 1911, Le Bestiaire ou Cortège d'Orphée, including from the notes, are taken from Apollinaire 1965, CEuvres poétiques, 1-35.

5 See also Hermes Trismegistus no date.

6 Sutherland 1979.

7 Apollinaire, Le Larron, Apollinaire 1965, 91.

8 Sutherland 1979.

9 Francis Bacon, Study after Velázquez's Portrait of Pope Innocent X (1953). See also Crowley 2013, and Mathews 2007.

10 Freud 1985.

\section{Bibliography}

Apollinaire, G. 1911. Le Bestiaire ou Cortège d'Orphée, illustrated by Raoul Dufy. Paris: Deplanche. Apollinaire, G. 1965. CEuvres poétiques, preface by André Billy, text established and annotated by M. Adéma and M. Décaudin. Bibliothèque de la Pléiade. Paris: Gallimard.

Beckett, S. 1973. Not I. London: Faber and Faber.

Crowley, M. 2013. 'Deleuze on painting', French Studies 67.3, 371-85.

Dolittle, H. (H.D.) 1984 (first published 1956). Tribute to Freud. New York: New Directions.

Freud, S. 1985. 'The theme of the three caskets', in The Pelican Freud Library 14, Art and Literature. London: Penguin Books.

Hermes Mercurius Trismegistus, no date (first published 1650). The Divine Pymander, translated by John Everard. First Rate Publishers.

Mathews, T. 2007. 'Space, place and virtuality: Gilles Deleuze with Francis Bacon and Alberto Giacometti', in Porous Boundaries: Texts and images in twentieth-century French Culture, edited by J. Game. Modern French Identities 44. Oxford: Peter Lang Publishing.

Rimbaud, A. 1873. Une Saison en Enfer. Brussels: Alliance Typographique.

Shaw, G. (ed.) 2011. Graham Sutherland: An Unfinished World. Oxford: Modern Art Oxford.

Sutherland, G. 1979. Apollinaire, le Bestiaire ou Cortège d'Orphée. London: Marlborough Fine Art Ltd. 


\title{
8 \\ Notes Towards a Hybrid Bestiary
}

\author{
OUT OF APOLLINAIRE, SUTHERLAND AND OTHERS
}

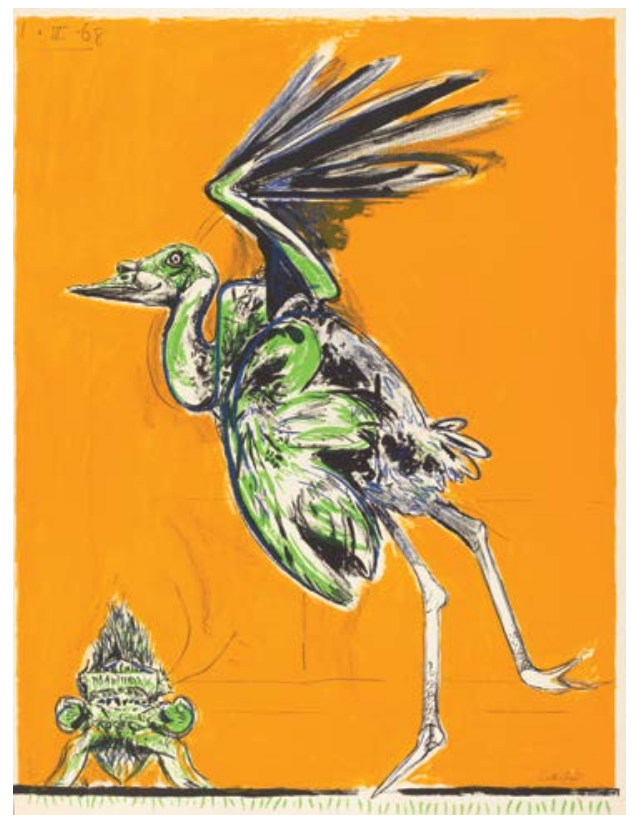

GEORGE SZIRTES

2017

Graham Sutherland, 'Bird About to Take Flight', from A Bestiary and Some Correspondences, 1968. (C) Estate of Graham Sutherland. Photo courtesy of the National Gallery of Art, Washington 
Poems composed for the occasion of the symposium

Apollinaire \& Sutherland: Translating Animals and Art Forms

NYU London 17 June 2017

Organised by Sarah Kay and Timothy Mathews

With particular thanks for fascinating papers to Sarah Kay, Rachel Mundy, Sarah Spence, Matthew Senior, Timothy Mathews, Monica Bohm-Duchen and Clive Scott.

\section{La Chenille}

Le travail mène à la richesse.

Pauvres poètes, travaillons!

La chenille en peinant sans cesse

Devient le riche papillon.

Guillaume Apollinaire, from

Le Bestiaire ou Cortège d'Orphée

With his severed head rolling under the waves, Breaking the shifting columns of light into a swirl

of slivers and flecks...

Mark Strand, from 'Orpheus alone' 


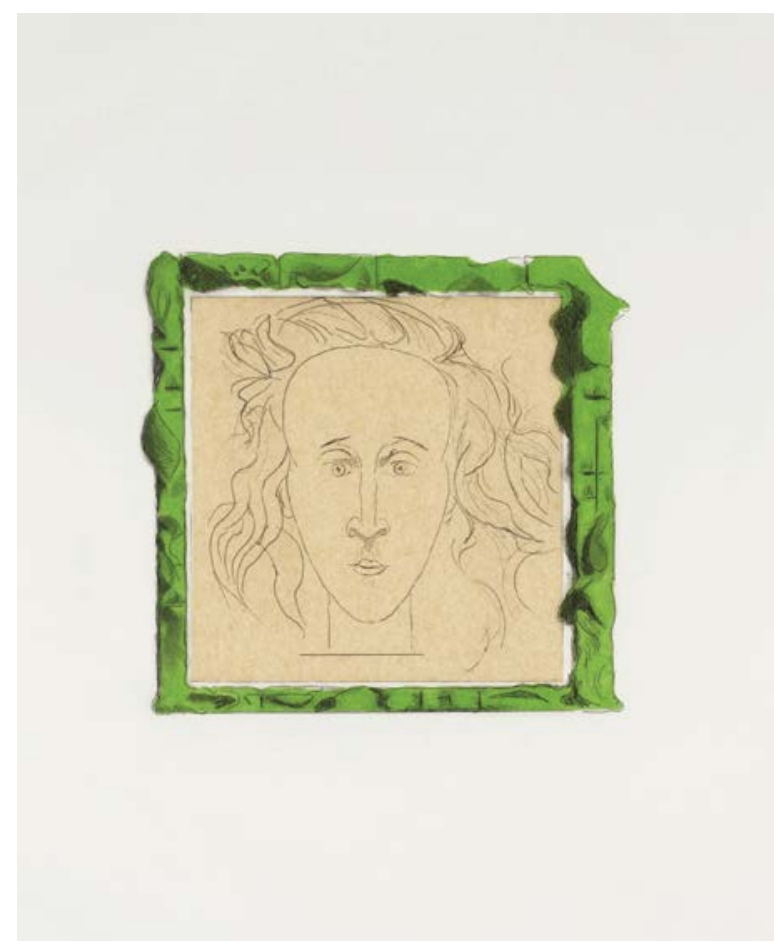

\section{ORPHEUS}

\section{Oh, to charm the birds off the trees! \\ To sing so everything follows. \\ Son of Calliope, hand us the keys \\ To the house of mysteries.}

I would love to have sung to demons, he said, or she said, in the dim light of the pub. One loses voices in the dark. One just sings. Or one turns the lights right off and tells stories to a room that has suddenly grown dense. That is the house of mysteries. That is where the dancers perform and tear you limb from limb. It is the animal kingdom without dictionary or cotologue raisonné. It is where you live.

Graham Sutherland, OM, from The Bestiary or the Procession of Orpheus, 1. 'Orpheus'. (C) Estate of Graham Sutherland. Photo (C) Tate Gallery, London 


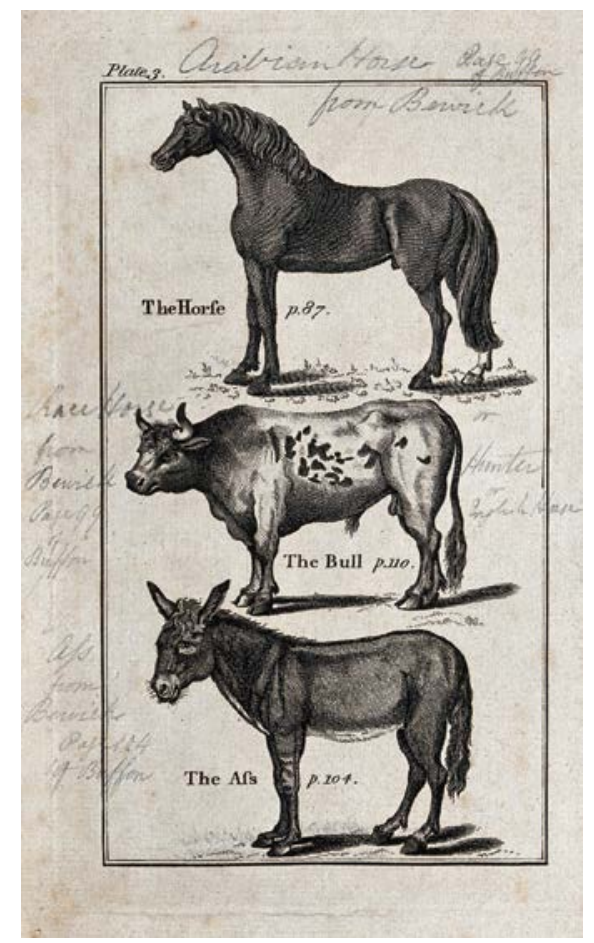

\author{
ASS \\ Speak to the load you bear \\ And to our patience, ever lacking. \\ Play Balaam to our dictionary \\ And send us packing.
}

In the donkey dictionary there are only brays, long or short, loud or quiet. Donkey poetics are as much duration as stress. The donkey Alexandrine and the donkey pentameter are only feet after all. The verb 'to bray' is as packed with ambiguities as the donkey itself. Someone has to bear the blame for this, someone has to carry the can. Open your mouth. Let the clear voice of reason emerge.

'Berwick Ass'. Above, a horse; below, a bull and an ass. Wood engraving after T. Bewick. Wellcome Collection. CC BY 


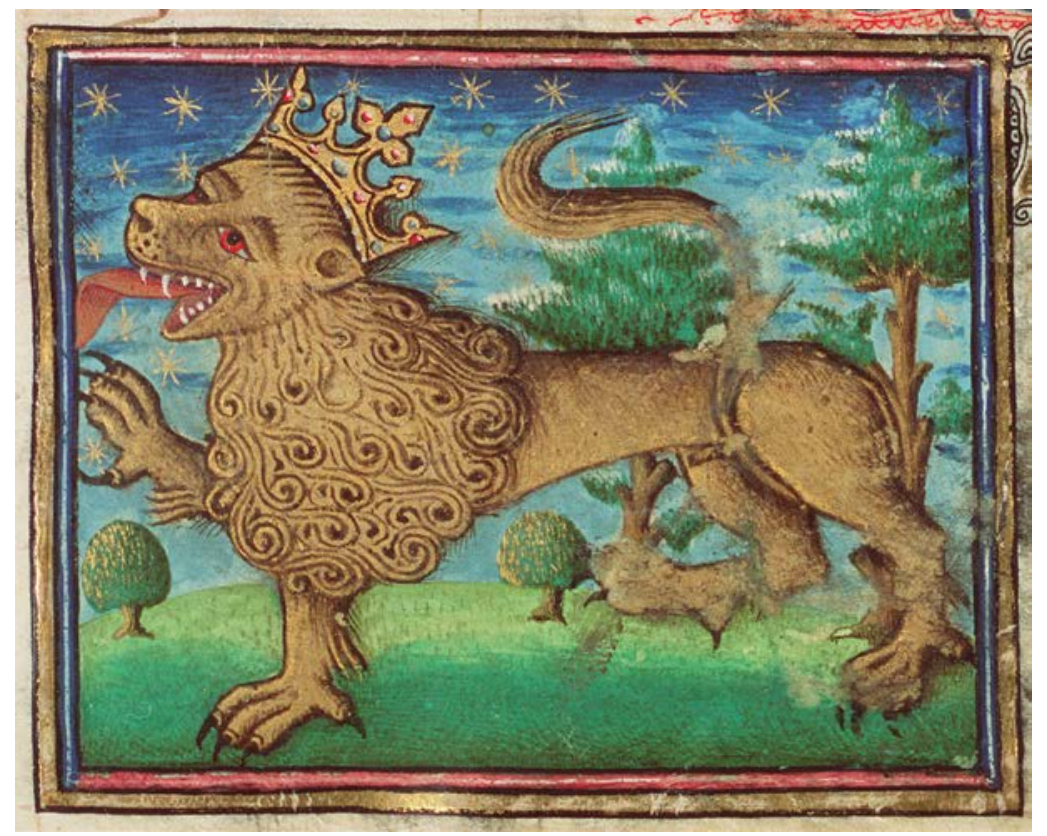

\section{LION}

Dance, rampant lion. Fling your mane

And roar, so nature flinches.

Stride about the world again

And make it yours by inches

It was our first lion and we were determined not to lose it. We tracked it along the savannah in an old jeep covered with crude portraits of film stars. Clark Gable's image decorated the grille. Dorothy Lamour was on the tailgate. Charles Laughton and Bud Abbott were on the doors, and Mary Pickford on the hood. If Hollywood was on our side nothing could happen to us. Then the lion came striding and we reversed into a handy nearby garage. We had forgotten the Andrews Sisters.

'Medieval Lion'. Leo (crowned lion), Bestiary, Western France, c.1450. Den Haag: House of the Book | Museum Meermanno, 10 B 25 


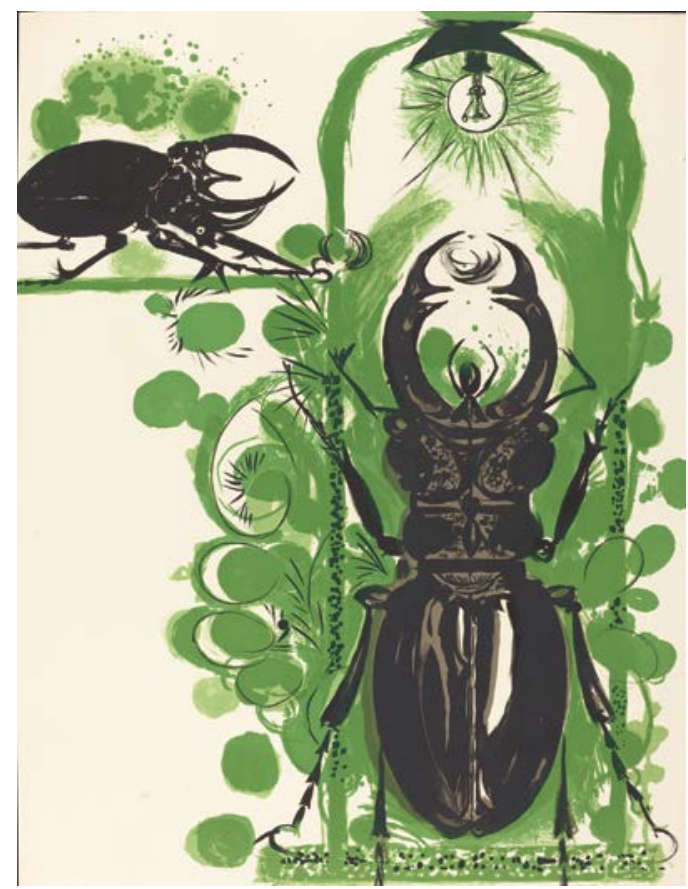

STAG BEETLE

Horned demon, stog beetle, Half insect, half Swiss-army-knife, Your armour seems impregnable. Have you come to take my life?

I have lived among insects all my life, he said, handing me a stag beetle. It was a magnificent specimen, a martial object equipped for both defensive and offensive operations. When propped up at 45 degrees it suggested a renaissance nightmare, the perfect rejection of humanism, but now, in my palm it simply sat like a philosophical problem. But there would be a solution, he said. There would be lots of solutions.

Graham Sutherland, 'Beetles II (with electric lamp)', from A Bestiary and Some Correspondences, 1968. (C) Estate of Graham Sutherland. Photo courtesy of the National Gallery of Art, Washington 


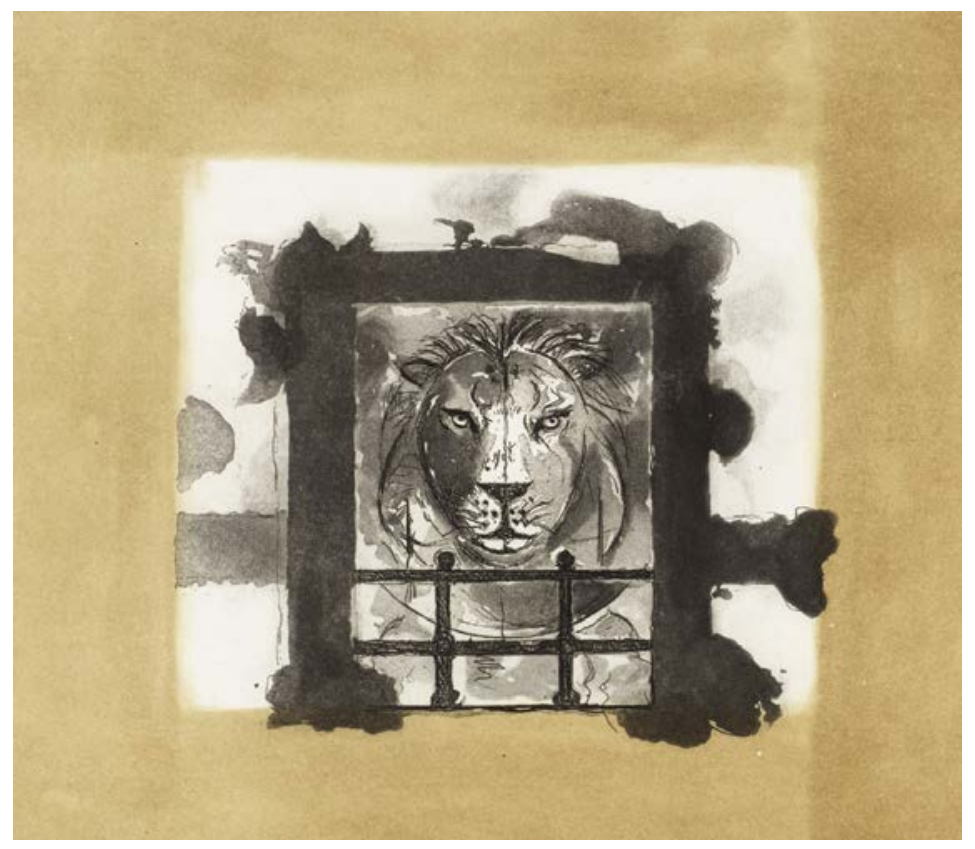

FIRE LION

Ever emerging out of the dark of the mental forest, your head of flames brings light and intolerable Heat, like setting fire to my bed.

The Fire Lion is to be found among your books, an incendiary waiting for the final conflagration. I can see one behind your brow right now stalking you like a giant apprehension. It won't stay there. It will emerge from your mouth, stately and terrifying. The books will burn of course but other books will rise from the ashes. The lion too will rise, the book of perfections in its mouth, its mind ablaze with the mottoes it finds there.

Graham Sutherland, OM, from The Bestiary or the Procession of Orpheus, 3. 'The Lion'.

(C) Estate of Graham Sutherland. Photo (C) Tate Gallery, London 


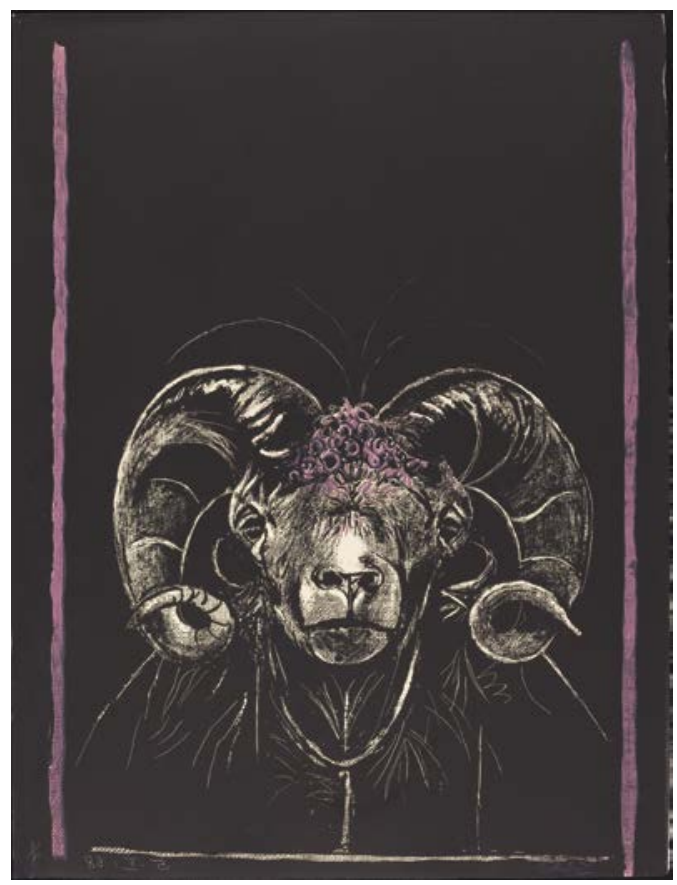

\section{RAM}

The skull curled about itself, worn As ornament, as bass clef, as strut And thrust. How have you become An image? How come you snap shut?

The ram is an orchestra by itself, a shofar, a bukkehorn. It resounds through the hall of mirrors that is God's house. There several reflected rams perform an arcane dance choreographed by Busby Berkeley. The politics may be dubious but their clear music is unmistakeable. Bring on the ram's horn. Wear it on your own head. Command the available space.

Graham Sutherland, 'Ram's Head Full Face', from A Bestiary and Some Correspondences, 1968. (C) Estate of Graham Sutherland. Photo courtesy of the National Gallery of Art, Washington 


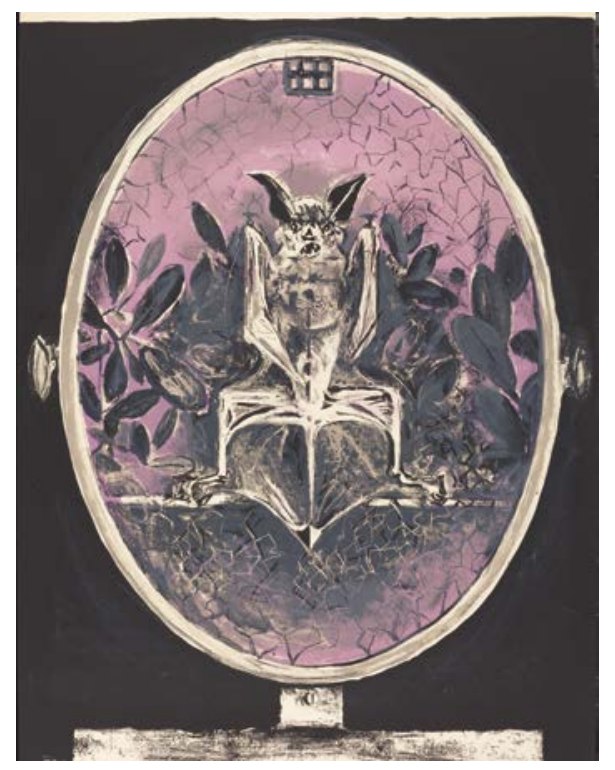

\title{
CHAUVE SOURIS
}

\author{
More trace than body, more dusk than night, \\ Nothing like bird or mouse in your address, \\ I imagine a huge hand crushing you \\ Into a speck, infinitely more of less.
}

The bat had flown in through the window and was now tangled in the open curtains. The city lay below us with the sleeping river, the domes and spires of the prevalent religion next to the great juggernauts of commerce, all its nightlife crawling down the street or scurrying along like defenceless mice. It was then the bat cried out and the curtains began to flap. The bat was still struggling. It was like an apple core with leathern wings. Leathern was a word we had found in the guidebook, appropriate for just such occasions.

Graham Sutherland, 'Chauve Souris (in a looking glass against a window)', from A Bestiary and Some Correspondences, 1968. (C) Estate of Graham Sutherland. Photo courtesy of the National Gallery of Art, Washington 


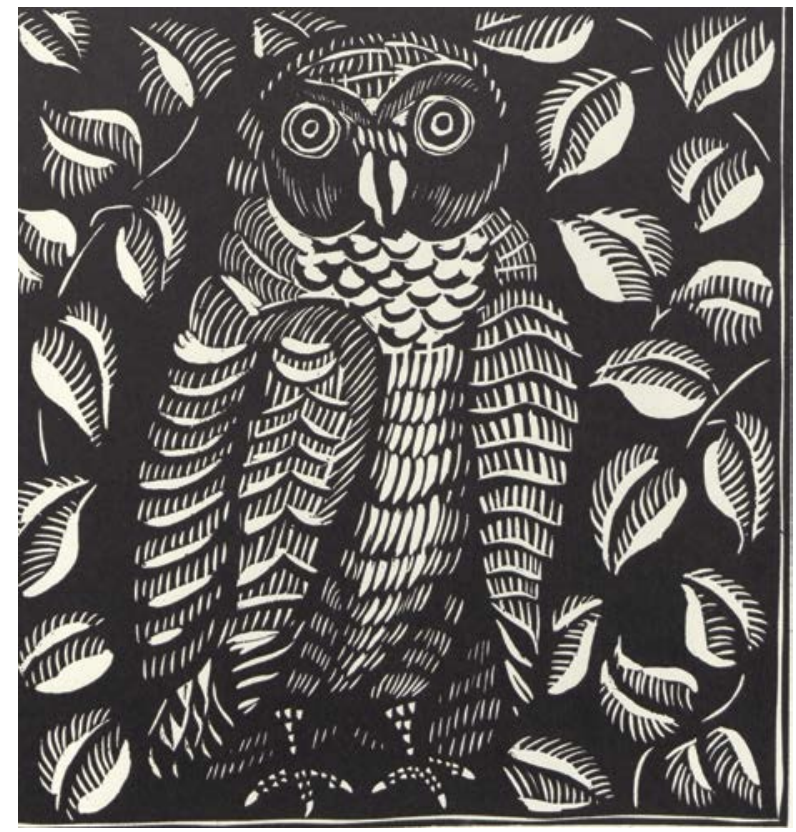

\section{OWL}

Crone of the Goddess, Wol, anagram

of Low, good luck to you and us.

Bring us the mice we require, Minervo.

Feed the cornivorous!

It sat in the middle of the road, temporarily dazzled by the oncoming headlights that it must have taken for the eyes of an enormous owl. The wood was full of owls, all watching, appraising the event with admirable self-control. The forest floor was littered with dead creatures, prey of some sort. Nobody was waxing sentimental about the owl, about any owl, least of all the one in the middle of the road. 


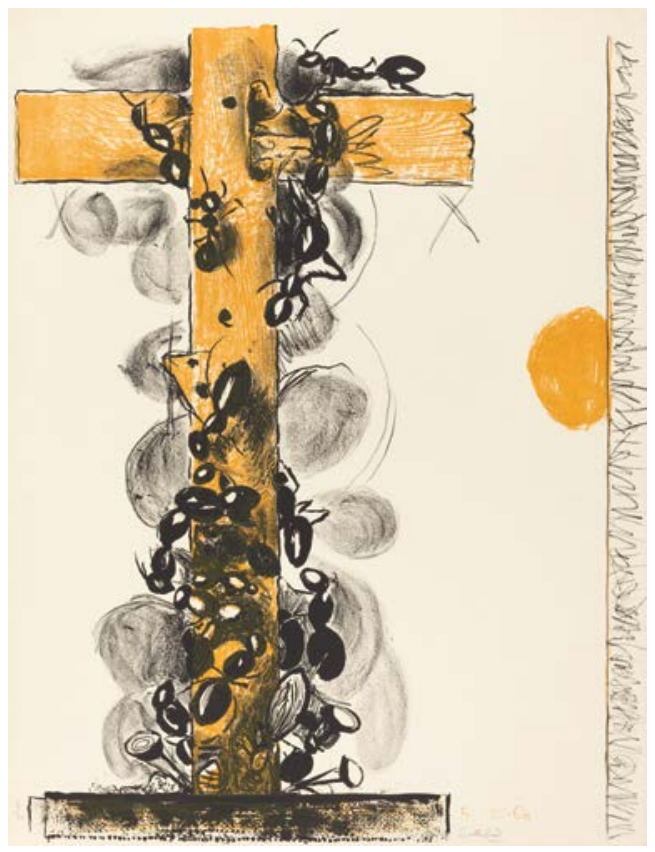

\section{ANTS}

May we address any one of you by name, Jack, Susan, David, Rose, and Beth?

Something creeps up the spine, like shame, Nomeless presences: work, scurrying, death.

We thought they were letters but they were ants. The book they were writing was the ant directory. Someone told us they were the dead of two world wars but they kept jostling about the page writing ever more names. This is their memorial, it said on the title page. They are dead but they will answer if you call, unless they are ex-directory, in which case you will have to call someone else. I consider my dead: Jack, Susan, David, Rose, Beth, Alfred, Danny, Amy, Xavier, Baby, Ronald.

Graham Sutherland, 'Ants', from A Bestiary and Some Correspondences, 1968. (C) Estate of Graham Sutherland. Photo courtesy of the National Gallery of Art, Washington 


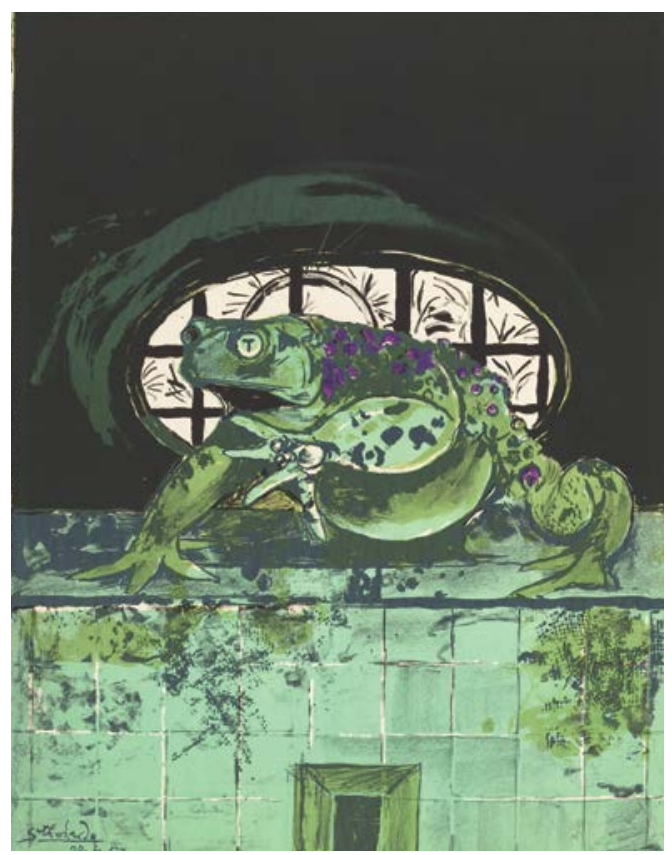

\section{TOAD}

Let me versify you into life, In your oilskin coat, with your outspread toes. I want to feel you leap right through my chest Like phlegm in my mouth and nose.

Between wall and fence, in a puddle of its own, the toad squatted. It must have been about important business because it barely noticed me and did not look up at my approach. You will have to sit down and wait your turn, I can't do everything at once, it eventually remarked. So saying it leapt into my open mouth and began to dictate affairs. It was only when I sneezed that it politely made its exit and settled back into a damp pocket of the universe.

Graham Sutherland, 'Toad', from A Bestiary and Some Correspondences, 1968. (C) Estate of Graham Sutherland. Photo courtesy of the National Gallery of Art, Washington 


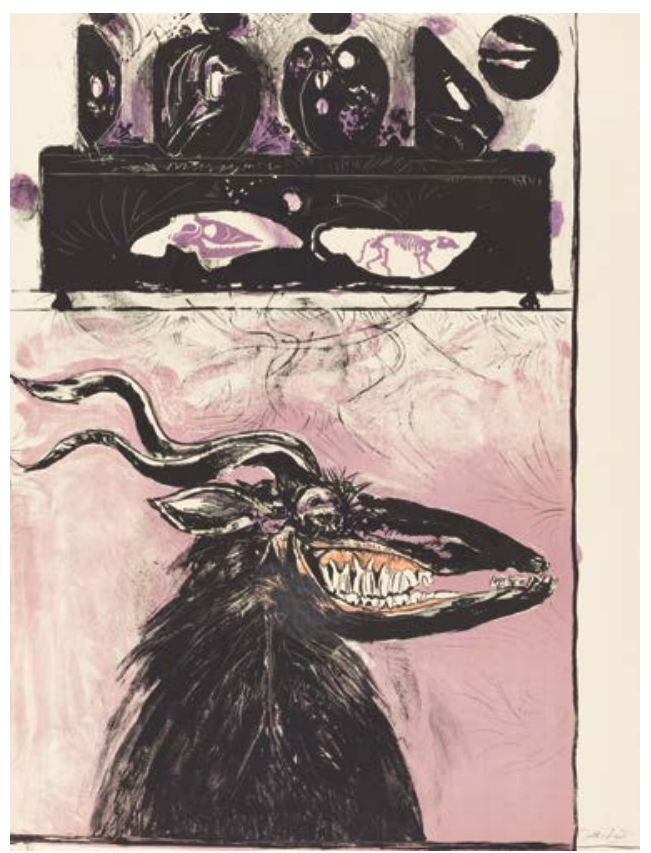

\title{
RAM'S HEAD WITH ROCKS AND SKELETON
}

\author{
The beauty of horror, the horror of beauty. \\ somewhere at the back of the Gothic ark \\ Lies the imagination, a freight of bones \\ And lightning in the terminal dark.
}

Her head was upside down. She was clearly a Goth. Goth was the fashion of the time and generally involved some level of evisceration. She told me her name was Nosferatu and spat a small bullet of blood at my shoes. A woman ran shrieking down the hall while a ghost was vainly trying to push its way through the wall in pursuit of her. Are you Charles Bukowski, asked a young girl clamouring for an autograph. Good heavens no, I said. I am not worthy to touch the hem of his garment.

Graham Sutherland, 'Ram's Head (with rocks and skeletons)', from A Bestiary and Some Correspondences, 1968. (C) Estate of Graham Sutherland. Photo courtesy of the National Gallery of Art, Washington 


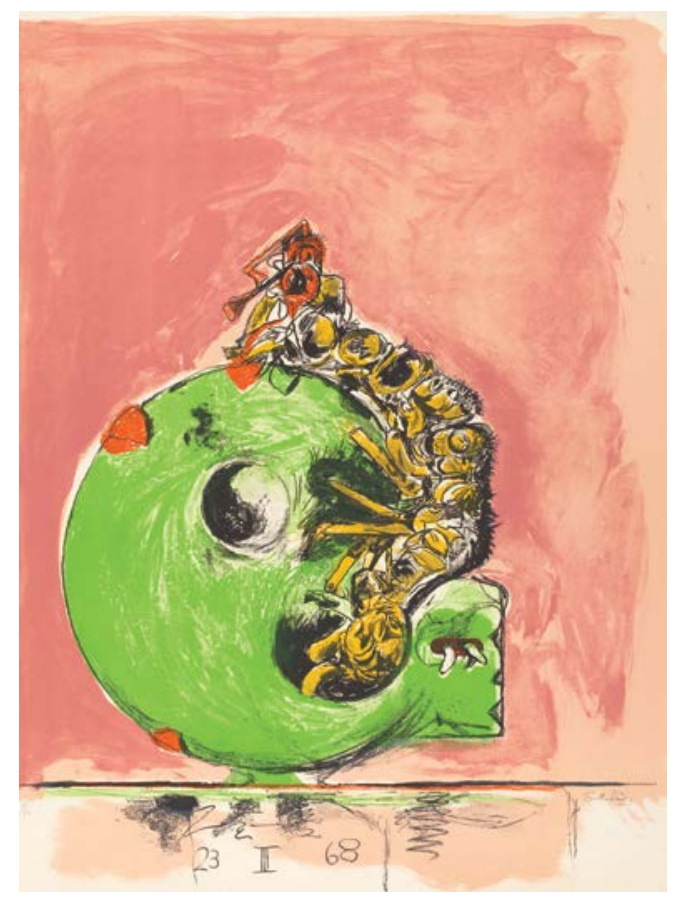

\section{EMERGING LIFE FORM}

Like the alien bursting from John Hurt's stomach

So nature haunts the artificial moon.

The place is crowling with emergence, a caterpillar in its slick cocoon.

I was born on a Friday and have ever since regretted it. Bound in slime I sat on the floor, helpless with desire. The days were passing but there was no change in my circumstances. I couldn't move. I couldn't escape. There was no one around to help me. There was only the moon in the window like a head without a face. This can't be everything, I thought. It is not what I came for. 


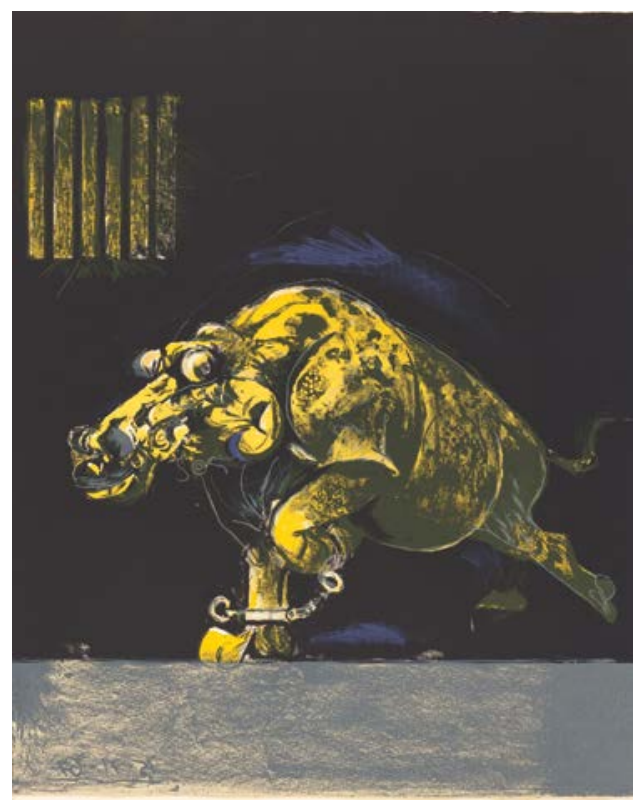

\section{CHAINED BEAST}

Slouching towards Bethlehem to be born, He hesitates before heaving a great sigh. It need not always be so troublesome To reach your destination and to die.

I will tell you when it's time for a new god, he said. For now you will have to make do with that snarling mass of impotence in the cage there. The old god looked at me, its eyes surprisingly benign. It was a little unkempt. No one had brushed its mane or picked the lice off its ears. Forgive my appearance, it said. I was not always as you see me now. I had a suit, a hat, a decent pair of shoes. I smelled of death. Behind my eyes, in the far distance, you could make out a battlefield full of crows and broken standards.

Graham Sutherland, 'Chained Beast', from A Bestiary and Some Correspondences, 1968. (C) Estate of Graham Sutherland. Photo courtesy of the National Gallery of Art, Washington 


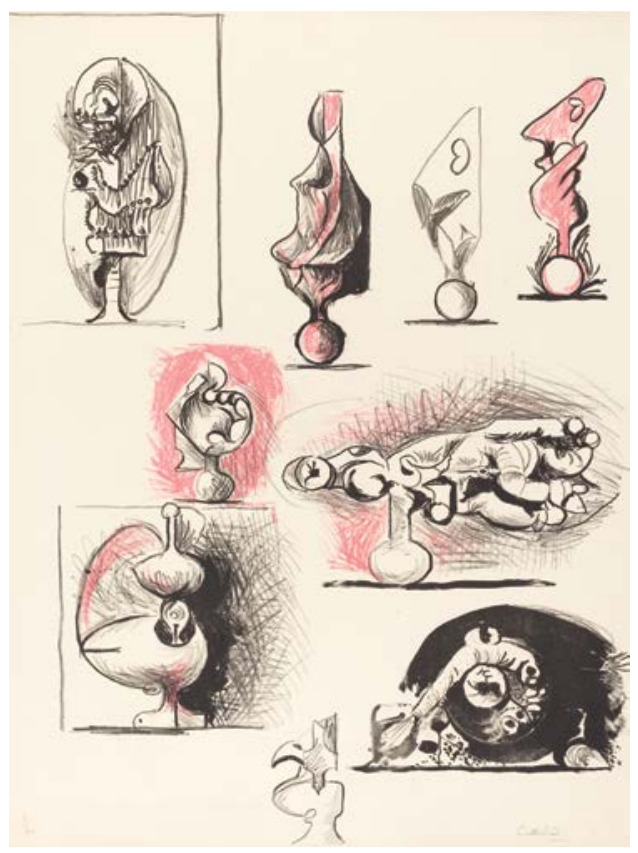

\section{HYBRID}

I am nothing. I am neither here nor there, A citizen of the world, trans-everything That is the case. I may not belong where you are But I have teeth and at least one good wing.

Life on the fence is the only life, he told me as I stood opposite him on the fence. He gave me his name and I gave him mine. The fence looked fairly recent and well maintained. Below us the sea bubbled and gasped. That is the best of it, he said. The view, the startling freshness of the air, the sheer discomfort. Further along the fence someone else was approaching, precariously balanced, swaying from side to side then righting himself. It was no one I knew. It would be a short conversation.

Graham Sutherland, 'Sheet of Studies (organic forms)', from A Bestiary and Some Correspondences, 1968. (C) Estate of Graham Sutherland. Photo courtesy of the National Gallery of Art, Washington 


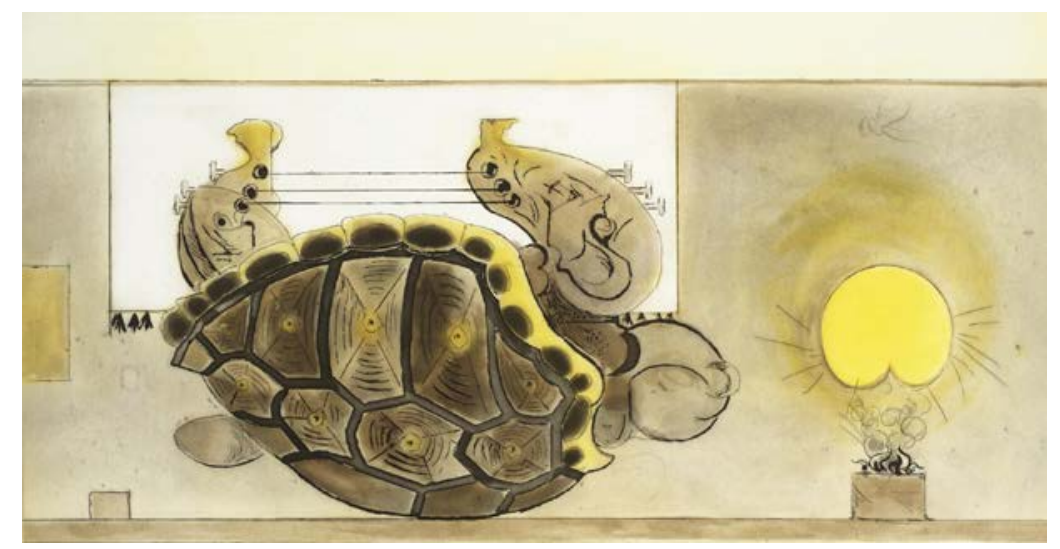

\section{TORTOISE}

Carapace, plastron, crepuscular... Your vocabulary crowls from under the tongue

The way you do between rocks. I am your lyre, the song that goes unsung.

In one of Ovid's forgotten metamorphoses Orpheus is turned into a tortoise. He has retreated into his shell and it takes the Maenads to entice him out. It doesn't end well. It never does. But the music remains, echoing in his shell as under a helmet. That is what tragedy is for.

Graham Sutherland, OM, from The Bestiary or the Procession of Orpheus, 2. 'The Tortoise'.

(C) Estate of Graham Sutherland. Photo (C) Tate Gallery, London 


\title{
Tailpiece
}

\author{
Sarah Kay
}

One of the Press's readers amused us, in their review of our manuscript, by writing that 'many of these figures' (that's to say us) 'are of an older generation'. They went on, 'I really enjoyed reading what might be considered "late" writings by authors who have clearly relished the opportunity to creatively examine (and often experiment with) the visual and linguistic poetics of these three modernist practitioners.' The contributions to this volume may or may not be 'late' writings, but it is true that they have been thought out, written, presented and discussed, revised, and edited, with a great deal of enjoyment. Much of that comes from the sheer pleasure of engaging with our three modernist subjects: Apollinaire, Dufy and Sutherland. But the exuberance and energy of the writings gathered here also owes much, I think, to changes in the humanities which we - both the older and younger among us have actively helped to bring about. Scholarship focused on a recognised area of specialisation will probably never lose its importance, but for many of us writing today the most rewarding challenges have come from more open-ended kinds of intellectual venture. In the case of my co-editor Timothy Mathews, that has involved engaging with multiple creative arts - poetry, painting, sculpture - and their interactions, while at the same time elevating literary translation and critical writing into art forms in their own right. In my own case, it has mainly meant embracing the constellations of interconnected thinking that make up the new transdisciplinary fields of animal studies and sound studies. These explorations of critical creativity and transdisciplinary studies are distinct from one another, but they have in common that work is judged not, or not mainly, against traditional scholarly benchmarks of adequacy to knowledge, but by its capacity to respond to - and excite - ideas and experiences of mutual interest. 
This spirit of venturesome excitement and response is what animates this volume. It brings together writers whose specialist training lies in widely differing fields: Classical Latin (Sarah Spence), medieval studies (me), French seventeenth-century literature (Mathew Senior), musicology (Rachel Mundy), and modern French poetry and translation (Timothy Mathews and Clive Scott). None of these academic trajectories has directly prepared us for the central preoccupation of this volume, which, in Mathews' words, is to seek to understand 'the impulse of visual and verbal artists to understand their own work through each other's'. I quote here from his essay in this volume exploring the experiences of multiplicity and fluidity, of seduction and resistance, that characterise his own encounters with these art works. Mathews is a translator of poetry, and his own translations - here and elsewhere - brim with involvement; so too do his alert juxtapositions of Apollinaire's verse with the poet's own prose annotations (which, apparently, were what drew Sutherland into the poetic world of the Bestiaire in the first place).

In a larger sense, all the pieces in this volume are essays in translating verse and image into prose, culminating in George Szirtes' poetic bestiary, the most recognisable demonstration of creative activity in our volume, which comes complete with its own prose poems. In tribute to Apollinaire and Sutherland, Szirtes composed this work expressly for this collection, and it is a great pleasure and honour to be able to unveil it here. Scott's essay, too, manifests a playful approach to his lifelong interest in versification, opening it to translation understood in the widest sense as what happens when animals are translated into verse (what Scott calls Apollinaire's 'metamorphic zoopoetics'), when words are translated into images and back again ('intersemiosis'), and when these complex processes are translated into Scott's own witty bestiary entries.

A creative response to the effort of plumbing a wordless experience can be traced in many of the other pieces assembled here, whether in Mundy's reflections on the musical interpretation of animal sounds or Spence's on elegy, a form which, she shows, conjugates across the tenses the presence of death in life and of shade in light: life is never extinguished, always mitigated, forever in the process of translation. As Senior, quoting Marcel Detienne, puts it, the animals, poems and images that are our focus make heard, like Orpheus, 'a voice that is anterior to the articulated word'. Or Szirtes, in his Orpheus entry:

One loses voices in the dark. One just sings. Or one turns the lights right off and tells stories to a room that has suddenly grown dense. 
That is the house of mysteries. That is where the dancers perform and tear you limb from limb. It is the animal kingdom without dictionary or catalogue raisonné. It is where you live.

This point where the outlines of human language dissolve before the animal on the one hand, and sheer sonority on the other, can be described as lying at an intersection between animal studies and sound studies. The meeting point of these two approaches, in turn, aptly describes the relationships between some of our contributors. It was through animal studies that I first met Matthew Senior, whose writings I had often turned to, and who then approached me as he was planning his compelling volume of Yale French Studies called Animots: Postanimality in French thought. ${ }^{1}$ And it was through both animal studies and sound studies that I got to know Rachel Mundy, author of Animal Musicalities, which argues that 'modern sonic culture is unthinkable without the lives of animals' - and more particularly the last moments of those lives, since she chillingly identifies vivisection as one of the founding practices for the study of music. ${ }^{2}$

The influence of animal studies, as each of these scholars understands it, informs their contributions to this volume. Reflecting on the French music produced around and following Apollinaire, Mundy shows the proximity of the bestiary to the circus and of both to parading taxonomies that spill out, from the procession of individually distinct beasts, to colour attitudes more broadly to gender, race and class. Senior contrasts the portrayal of animal life in the Apollinaire-Dufy bestiary with that of Sutherland, showing how it is assimilated to the same plane as the human life in the earlier work, but stripped back to the condition of bare life by Sutherland in a movement that exactly parallels twentieth-century developments in biopolitics. Awareness that the human is inevitably conjugated with the animal also energises the collection as a whole, from the vitalism of Spence's Orpheus, poet of nature, to the uncanny of Szirtes' toad or hybrid.

The enjoyment we have all found in working together on this volume comes from the overlapping pleasures and interests generated by working on multiple art forms creatively and connectedly across multiple disciplines, given over, in Mathews' words again, 'to the rhythms of these imaginary yet living proximities'. We asked our readers, when they entered this book, to share the experience of these modernist bestiaries; we encourage them, as they leave it, to enjoy exploring everbroader horizons for the humanities. 


\section{Notes}

Senior, Clark and Freccero 2015.

Mundy 2018, 3.

\section{Bibliography}

Senior, M., Clark, D.L. and Freccero, C. (eds.) 2015. Animots: Postanimality in French thought, Yale French Studies 127.

Mundy, R. 2018. Animal Musicalities. Birds, beasts, and evolutionary listening. Middletown: Wesleyan University Press. 


\section{Index}

References to Guillaume Apollinaire, Raoul Dufy and Graham Sutherland as well as Orpheus are integral to the fabric of the text and are not itemised here. The same applies to references to Le Bestiaire ou Cortège d'Orphée and The Bestiary or the Procession of Orpheus. The titles of other works by Apollinaire, Dufy and Sutherland are listed under their names, except for ones referring to animals. The latter are included in the entries for those animals, and conversely entries for animals include titles of works by that name. Other authors and artists are listed by name and not by titles of works. Illustrations and graphics are indicated by their numbers, or page numbers in italics. $\mathrm{n}$ denotes note

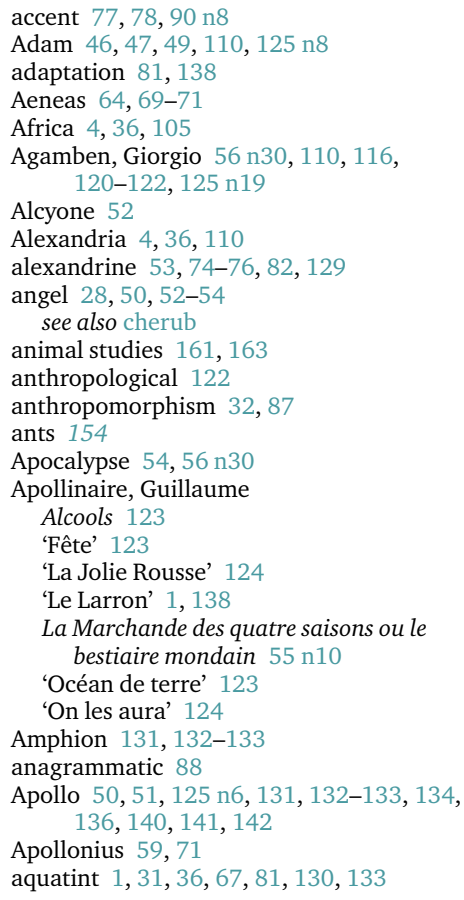

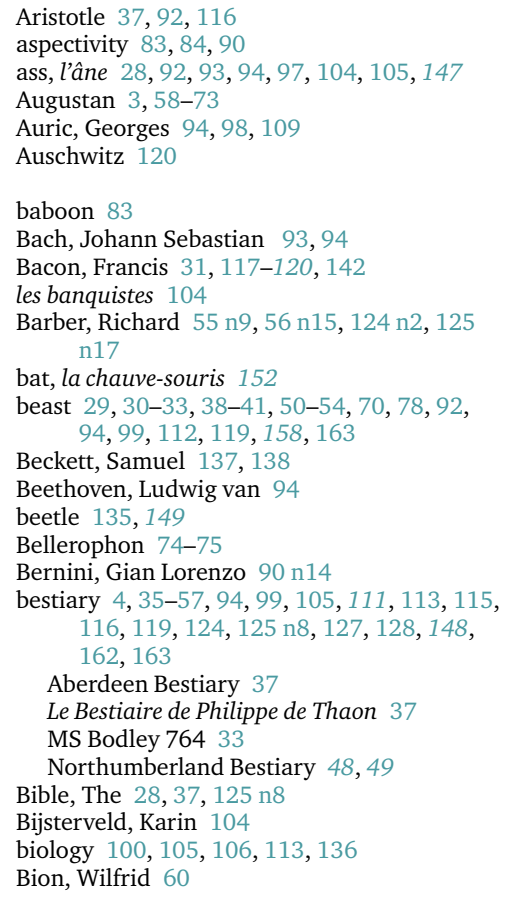


biopolitical 121, 122

bios 116, 117

boar 29, 70

Bohn, Willard 90 n14

Boime, Albert 101, 104

Boulez, Pierre 77

boundaries 72, 100, 131

Brahms, Johannes 95

Brunhoff, Jean de 95, 105

butterfly, le papillon 145

Cage, John 82

calligrammatic 85,88

Calliope 5, 60, 146

camel 101

Camus, Albert 120, 121

carp, la carpe 40, 45, 67, 80, 87-89, 90 n14

cat, le chat illustration $4 ; 40,43,67,77,80$, $102,115,116,123$

catacomb 60, 67, 72 n5

caterpillar, la chenille 40-42, 44, 52, 56 n19, $68,145,157$

Catholic 31

Catling, Brian 128

Cauchon, Pierre 93

Ceyx 52

cherub 27-29, 33, 45, 53, 54;

see also angel

chickens 101

choriambic 79

Christian 28, 31, 37, 38, 43, 45, 47, 52, 60, 66, 67, 74, $90 \mathrm{n} 14,110,123,129,133$,

Circe 70 139,140

circus 2, 92-109, 163

Le Cirque Fernando 102, 103

Le Cirque Médrano 99-101

class $41,52,100,104,105,106,163$

classical 28, 33, 66, 75, 94, 96, 129, 130, 131, 136,162

Claudel, Paul 93, 95

Cleopatra 45, 72 n6

Clifford, Rosamunde 139

Cocteau, Jean 95, 98, 99, 104, 107 n5

cosmological 41

coupe enjambante 75

coupe lyrique 75,78

Couperin, François 95

Coventry Cathedral 28

crayfish, l'écrevisse 40, 45, 80

Crowley, Martin 143 n9

cubism 83, 130, 135

Daniel $72 \mathrm{n} 5$

Dante, Alighieri 28, $72 \mathrm{n} 8$

Daudet, Lucien 98

death $3,52,59,60,64,65-68,71,72,85,87$, $88,113,118,119,124,131,137,141$, $142,154,162$

Debussy, Claude 95

Degas, Edgar 99, 104

Deleuze, Gilles and Guattari, Felix 77

Detienne, Marcel 111, 162

$\operatorname{dog} 101$

Dolittle, Hilda, H.D. 127

dolphin, le dauphin 40, 42, 52, 80, 123 dove, la colombe 40, 42, 43, 80

dromedary, le dromadaire 40, 77

Durey, Louis 94, 95, 96, 97, 98, 105, 109

Egypt 43, 83, 84, 86, 92, 100, 119, 129

elegy 3, 53, 56 n28, 59, 63-68, 70, 71, 162

elephant, l'éléphant illustration 13; 31, 40-42, 46, 47, 51, 52, 66, 67, 68, 95, 97. $101,105,112,113,115,119,136-138$, 141

enigma 2, 4, 43, 44, 45, 47, 50

Euripides 3,60

Europe 31, 36, 39, 93, 99, 100, 105

Eurydice 45, 58, 59, 60, 63, 64, 72, $72 \mathrm{n} 6$, 139

Eve 45, 46, 72 n6

Ezekiel 53, 54

Fauconnet, Guy-Pierre 98

fête foraine 99

fish $36,40,41,43,52,59,82-84,88,111$, 139,140

flea, la puce 32, 40-42, 80, 115, 141

fly, la mouche illustration 15; 5, 40, 41, 44, $52,56 \mathrm{n} 19,67,117$

fox 93

I Fratellini 98

free verse 79, 82

Fresnay, Roger de 98

Freud, Sigmund 127, 141, 142

Le Gaulois 99

Gautier, Théophile 76

gender 100, 105, 106, 163

Genesis 45,47

genre 37-39, 47, $55 \mathrm{n} 5,59,106,110,115$

goat, la chèvre du Thibet 40, 42, 80, 96, 97 , 98, 112

Goya, Francisco 30

grasshopper, la sauterelle 31, 40, 41, 56 n20, $67,80,97,115$

Greek 32, 36, 40, 110, 116, 129, 131

Guattari, Felix and Deleuze, Gilles 77

Guichard, Hélène 83

Hades 60, 61, 62, 64

Hammer, Martin 117, 119

hare, le lièvre 40, 43, 80

Heliades 61

heraldic 31

Hermes 35, 47, 50, 51, 124 n4, 125 n6, 129

Hermes Trismegistus, Hermès Trismégiste 35, $36,37,42,50,55,55$ n3, 56 n16, 110, $128,129,130$

hippopotamus 29, 30, 83

history $2-5,29,36,37,40,56 \mathrm{n} 23,60,71$, 92-109, 121, 128, 131-133, 135

Holocaust 119, 121

Honegger, Arthur 93-95, 97, 98, 100, 104-106, 109

horse, le cheval illustration 3; 33, 40, 45, 51, 53, 96, 101, 102, 104, 112, 134, 147

Hugo, Jean 98 
human $2-5,31-33,39,43,45-47,49,51,52$, $62,63,69,70,75,83,84,87,91$ n19, 95, 97, 101, 104, 106, 110-126, 127-143, 149, 163

humanities 161, 163

hybrid 117, 119, 159, 163

Hyde, Lewis $125 \mathrm{n} 8$

ibis, ibis illustration 7, 19; 3, 13, 40, 41, 44, 53, 56 n28, 65, 66, 68, 80, 83, 84-86, 119,141

insect, insecte 29, 40, 41, 43, 52, 54, $56 \mathrm{n} 19$, $69,115,117,138,149$

intersemiosis 74, 80, 81, 86, 90, 162

Isaiah 54

Jacob, Max 3, 66

Jakobson, Roman 80

Janczukiewicz, J. and Lefoll, N. 125 n26

Jason 67, 96

jellyfish, la méduse 40, 113

Joan of Arc, Jeanne d'Arc 93, 94, 95, 105, 106

Jones, Ernest 127

Jünger, Ernst 123, 125 n25

Jupiter 61

Kafka, Franz 135

Kahlo, Frida 31, 32

Kästner, Erich 95

Kay, Sarah 2-4, 55 n5, 55 n14, 124 n4, 125 n8, 145

kinaesthetically 3

Kipling, Rudyard 101, 102, 104

Klee, Paul 4

Koechlin, Charles 105, 106

Koubitzky, Alexandre 98

Latin $4,36,37,39,40,41,61,62,65,81,85$, $88,92,93,162$

Latin America 31

legend 3, 28, $125 \mathrm{n} 6,139$

legibility of animals 42, 44, 45, 50

Legrand-Chabrier, André 101

Levi, Primo 120, 121

Levy, Charles 102, 103

lion illustration $11 ; 30,31,40,41,43,44,46$, 47, 54, 56, 67, 68, 70, 72 n5, 80, 90 n14, 93, 94, 99-102, 110, 113, 114, 137, 148, 150

livre d'artiste 128

logos 116, 117

loss 3, 4, 59, 64, 66, 70-72, 130, 137, 138

machine $31,39,42,53,104,117,122$

Marlborough Fine Art, London 2, 27, 81, 129, 138

Mathews, Timothy 90 n1, 122, 143 n9, 145, 161-163

medieval 2, 4, 28, 31, 33, 36-43, 45, 47, 54, 92, 94, 104, 110, 112, 113, 119, 125 n8, 148,162

melancholy $3,5,88$

metamorphosis $39,71,74,84,88,162$

metaphor 2, 72, 77, 83, 84, $91 \mathrm{n} 19,136$

Mercury, Mercure 50, 74, 131, 132, 133, 136
Merovich, Juliette 98

metonymic $72,80,136,83$

Middle Eastern 36

Milhaud, Darius 94, 95, 98, 99, 105, 109

Milner, J.C. and Regnault, F. 90 n8, 90 n12

modernism 98, 105, 106

monkey 100, 101, 105

monster 5, 69, 29, 72 n5, 78, 79, 113, 142

Montmartre 95, 98,99

Montparnasse 95

Morand, Paul 98

Le Moulin Rouge 99

mouse, la souris illustration 12;31, 40-43, 68, 152

Munch, Edvard 51

Mundy, Rachel 2, 3, 6, 145, 162, 163

music $2,6,28,33,39,47,50,53,59,60,68$, 74, 92-109, 125 n6, 136, 137, 151, 160, 162,163

myth $4,28,29,32,33,38,39,42,45,52,59$, $64,68,69,115,129,131,136$

naming animals $4,47,49,54$

nationality $2,83,94,105,106,121,124$

nature $3,29,30,33,35-57,59,65,68,71$, 72, 92-109, 116, 125 n8, 148, 157, 163

Neilson, Christina 111

Neptune 70

nightingale 62,69

Niobe 131

octopus, la pieuvre, le poulpe illustration 5, 17; 40-42, 46, 52, 67, 69, 78-82, 85, 89, $113,123,124,142$

octosyllable $74,76-82,84$

Offenbach, Jacques 97

ostrich 41

Oulipian 92

Ovid $3,38,58-73,160$

owl, le hibou 29, 40, 42, 44, 53, 70, 77, 80, 115,153

ox, le bœuf illustration 8; 27, 28, 29, 33, 40, 41, 45, 53, 54, 55, 56 n29, 56 n30, 80, 117,147

papier japon impérial 46

paralinguistic 77,87

parataxis 78

parchment $45,46,125 \mathrm{n} 8$

peacock 40, 53, 72 n5

Pegasus 51, 74, 75, 102, 104, 134

Penrose, Roland 30

Phaethon 61

phōne 116, 117

Physiologus 36, 37, 38, 40, 43, 51, 52, 110

Picasso, Pablo 55 n10, 95, 98, 99, 104, 117, 119,130

pig 79, 93, 94, 101

plants $68,83,84,112,118,119$

Pliny 37

poetry $3,5,29,36,37,51,64-68,71,72,75$, 110, 113, 124, 129, 132-134, 137, 139, $142,161,162$

Poulenc, Francis 2, 94-97, 98, 105, 106, 109

pyre illustration 20;33, 41, 55, 135, 141 
race $105,106,163$

Radiguet, Raymond 98

ram 29, 151, 156

Ravel, Maurice 95, 97

Regnault, F. and Milner, J.C. 90 n8, 90 n12

Renaissance 113, 131, 149

Revelation, Book of 53

rhinoceros 29, 30

rhyme $47,65,77,78,79,87,88,116$

rhythm 42, 43, 46, 77, 79, 84, 85, 87, 95, 96, $100,128,129,137,163$

Rimbaud, Arthur 133

Roman 131, 137

St John the Baptist 115

St Luke 28

St Mark 90 n14

Saint-Saëns, Camille 97, 105

saltimbanque 130

Satie, Erik 95, 104

Saussurean 83

Scarron, Paul 76

Scott, Clive 3, 6, 107 n12, 107 n14, 145, 162

Schütz, Heinrich 93

Senior, Matthew 3, 55, 145, 162, 163

sermon 43

Seurat, Georges 99, 104

sex $111,128,139,142$

sexuality $100,105,106$,

shade, ombre, umbra 28, 58-73, 162

shadow, ombre, umbra 3, 65, 73 n8, 74, 85, 119

Shaw, George 128

Sheep 72 n5, 93, 94, 112, 134

Simonides 59, 71

sirens, les sirènes illustration 6 and 18; 31, 40-42, 52, 53, 56 n30, 67, 75, 76, 99, $117,122,143$

Les Six 92, 94, 95, 98, 100, 105

snake, le serpent $32,40,41,45,68,72 \mathrm{n} 6,77$, $80,93,135,141$

Soury, Gustave 102

space $1,4,31,42,43,45,61,64,65,67,68$, 77, 78, 84, 89, 101, 107 n12, 128, 141, 151

species 41, 84, 100, 101, 105, 106, 117

Spence, Sarah 3, 56 n28, 145, 162, 163

Strand, Mark 3, 58, 64-67, 72, 84, 145

surrealism 29, 30

Sutherland, Graham

The Bees, 29

A Bestiary and Some Correspondences 29, 144, 149, 151, 152, 154, 155, 156, 157, 158,159

The Captive 30

Christ in Glory 28

'Chained Beast' 30, 158

Cigale 131
'Emerging Insect' 29

Fallen Tree Against Sunset 29

Gorse on Sea Wall 118

Green Tree Form: Interior of Woods 29, 30, 31, 118

'Insects (Simulating Seeds)' 29

Midsummer Landscape 118

Mobile Mask 30

Northamptonshire Crucifixion 29

Thunder Sounding 30

'Toad' 30, 155

Sylvester, David 118

Symbolists 101, 115

synaesthesia $68,74,80,81,86,90$

Szirtes, George 5, 162, 163

Tailleferre, Germaine 94, 95, 109

taxonomy 59, 65

tenses $58-73,162$

tetrameter 75,78

Thétard, Henry 100, 101, 104

Thoth 83, 85, 129

Thracia, Thrace 32, 50, 60, 112, 132, 133

tiger, tigre 93, 94, 100-102

toad 29, 30, 155, 163

tortoise, la tortue illustration 2 and 10; 28, 32, $33,40,41,45,50,51,55,63,65,66,74$, 96-98, 112, 131-136, 141, 160

Toulouse-Lautrec, Henri de 99

translation 2-6, 47, 74-91, 92, 134, 138, 143,

triolet 79 161,162

trope $87,97,105$,

Troy 64

Uexküll, Jakob von 84

Varèse, Edgar 100

Venetian 90 n14

Vergil 3, 58-73

vers libre 75

vers simple 76

Versailles 88, 90 n14

Vichy 94

Villard de Honnecourt 113

Villon, François 129

Visigoth 88

voice $35-57$

Wagner, Richard 94, 95

War Artists Advisory Committee 118

Warren, Rosanna 66

Whitelaw, Billie 137

Wood, Jean 81, 138

woodcut 1, 3, 4, 35, 45, 50, 51, 65-67, 111, $113,115-117,123,128,133$

zoe $116,117,121,124$

zoopoetics 74, 76, 83, 84, 90, 162 


'Enacting in multiple compelling ways the mobility and relationality at the heart of its concerns, this collection makes a major contribution to the various fields into which it intervenes, including modernist studies, translation studies, critical animal studies, and research into intermedial transmission, especially between text and image and text and music.' - Martin Crowley, University of Cambridge

The Modernist Bestiary centres on Le Bestiaire ou Cortège d'Orphée (1911), a multimedia collaborative work by French-Polish poet Guillaume Apollinaire and French artist Raoul Dufy, and its homonym, The Bestiary or Procession of Orpheus (1979), by British artist Graham Sutherland. Rather than reconstructing the lineage of these two compositions, the book uncovers the aesthetic and intellectual processes involved that operate in different times, places and media. The Apollinaire and Dufy Bestiary is an open-ended collaboration, a feature that Sutherland develops in his re-visiting, and this book shows how these neglected works are caught up in many-faceted networks of traditions and genres. These include Orphic poetry from the past, contemporary musical settings, and bestiary writing from its origins to the present.

The contributors' encounters with these works take the form of poetry and essays, all moving freely between different disciplines and practices, humanistic and post-humanist critical dimensions, as well as different animals and art forms. They draw on disciplines ranging from music, art history, translation, Classical poetry and French poetry, and are nurtured by approaches including phenomenology, cultural studies, sound studies, and critical animal studies. Collectively the book shows that the aesthetic encounter, by nature affective, is by nature also interdisciplinary and motivating, and that it spurs the critical in addressing the complex issues of 'humananimality'.

Sarah Kay teaches French, Comparative Literature and Medieval Studies at New York University. She has written widely on medieval texts across genres and languages. Her most recent books are Animal Skins and the Reading Self in Medieval Latin and French Bestiaries and Philology's Vomit: An Essay on the Immortality and Corporeality of Texts (both 2017).

Timothy Mathews is Emeritus Professor of French and Comparative Criticism, UCL. In his writing and translating he explores what relating to art can tell us about relating to people. He has written on many modern artists and writers, notably Apollinaire. His most recent monograph is Alberto Giacometti: the Art of Relation (2013). 